Environmental Impact Statement

\title{
Consideration of a
}

Waiver of the Moratorium and Return of Management of Certain Marine Mammals to the State of Alaska

VOLUME I

Summary and Text

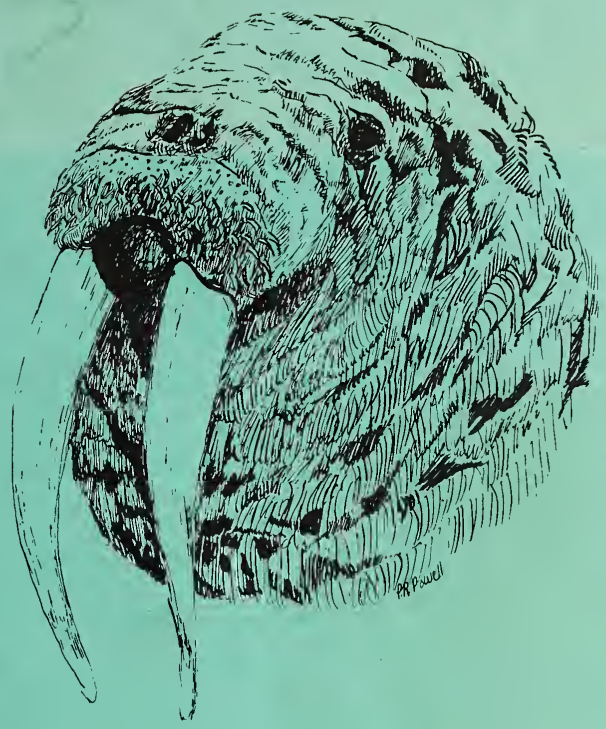

INTERAGENCY TASK GROUP

U.S. Department of Commerce, National Oceanic and Atmospheric Administration, National Marine Fisheries Service

U.S. Department of the Interior, Fish and Wildlife Service

Washington, D.C. 

CONSIDERATION OF A WAIVER OF THE MORATORIUM AND RETURN OF MANAGEMENT OF CERTAIN MARINE MAMMALS TO THE STATE OF ALASKA VOLUME 1

Summary and Text
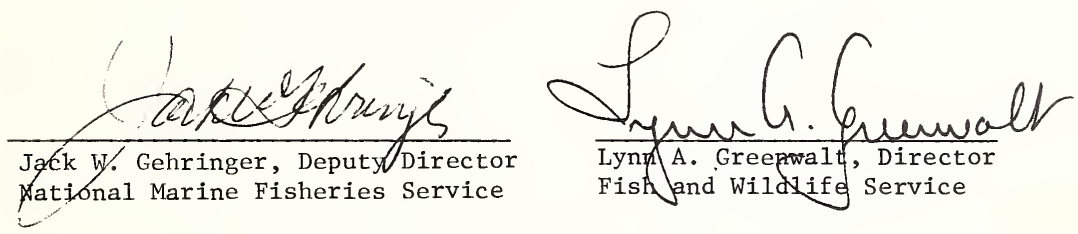

Interagency Task Group

U.S. Department of

Commerce

National Oceanic and

Atmospheric Administration

National Marine Fisheries

Service
U.S. Department of the Interior

Fish and Wildlife Service

Washington, D.C.

March 1978 


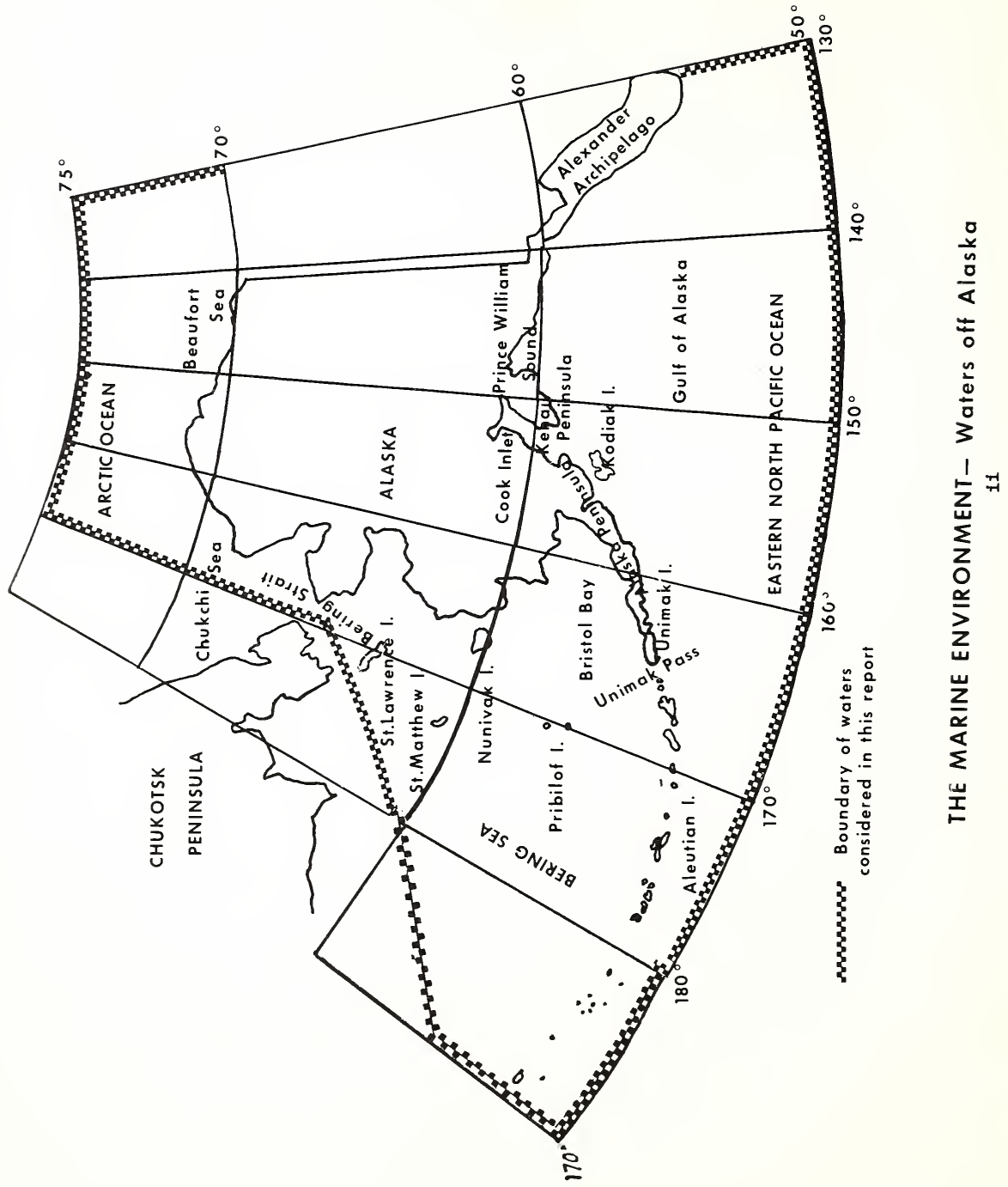


I. DESCRIPTION OF THE PROPOSED ACTION . . . . . . . . . . . 5

A. Background . . . . . . . . . . . . . . . . . . 5

B. The Species of Alaskan marine mammals . . . . . . . 14

C. Optimum sustainable population . . . . . . . . . 16

II. THE ENVIRONMENTAL SETTJNG FOR THE PROPOSED ACTION . . . . 20

A. The Marine environment - Waters off Alaska . . . . . . 20

B. The food web in waters off Alaska . . . . . . . . 23

C. Biology and optimum population éstimates of impacted marine mammals . . . . . . . . . . . . . 29

D. Ecological relations of marine mammals in waters off Alaska . . . . . . . . . . . . . . . . 79

E. The people, the economy, and hunting pressures in Alaska . . . . . . . . . . . . . . . 89

III. THE ENVIRONMENTAL IMPACT OF THE PROPOSED ACTION . • • . • . 96

A. Annual taking for sport, commercial and subsistence purposes . . . . . . . . . . . . . . . . 97

B. Current takings of marine mammals in Alaska not affected by the requested action . . . : . . . . . 99

C. Summary of estimated average annual take of marine mammals ................. 107

D. The impact of the proposed Eederal regulations and the State management program . . . . . . . . . . 110

1. Impact on species populations . . . . . . . . 110

2. Socioeconomic impacts. . . . . . . . . . 120

3. Other impacts ............... 123

E. The potential impact of specific State regulations . . 124

1. Regulations on native take . . . . . . . . 126

2. State of Alaska commercial taking permit requirements............. 127

3. Alaska marine mammal seasons and bag limits . . 127

4. Humane taking provisions . . . . . . . . . 128

IV. ALTERNATIVES TO THE PROPOSED FEDERAL ACTION . . . . . . . 130

A. Continue the moratorium and retain management authority under the Federal Government (No action) . . . . . 130

B. Continue the moratorium and transfer management authority to the State of Alaska . . . . . . . . . . 133

C. Waive the moratorium and retain management authority under the Federal Government . . . . . . . . . 135

D. Waive the moratorium and transfer management authority of only 'selected species to the State of Alaska . . 136

E. Waive the moratorium to a greater or lesser extent than proposed . . . . . . . . . . . . . 137 
V. UNAVOIDABLE ADVERSE ENVIRONMENTAL IMPACTS . . . . . . . 140

VI. RELATIONSHIP BETWEEN SHORT-TERM USE OF MAN'S ENVIRONMENT AND MAINTENANCE AND ENHANCEMENT OF LONG-TERM PRODUCTIVITY . . . . . . . . . . . . . . . . . . 140

VII. ANY IRREVERSIBLE OR IRRETRIEVABLE COMMITMENTS OF RESOURCES

IN THE PROPOSED ACTION SHOULD IT BE IMPLEMENTED . • . . 144

VIII. LITERATURE CITED . . . . . . . . . . . . . . 145

IX. COMMENTS AND RESPONSES . . . . . . . . . . . 152 APPENDICES (Volume II) 
1. Schematic of North Pacific surface circulation . . . . . . 22

2. Schematic of the biological cycle in the Arctic and subarctic...... . . . . . . . . . . . 25

3. Distribution of the polar bear . . . . . . . . . . 30

4. Distribution of the sea otter . . . . . . . . . . . 37

5. Distribution of the sea lion . . . . . . . . . . . 45

6. Distribution of the walrus . . . . . . . . . . . 49

7. Distribution of the harbor seal and spotted seal . . . . 55

8. Distribution of the ringed seal . . . . . . . . . 66

9. Distribution of the ribbon seal . . . . . . . . . . 70

10. Distribution of the bearded seal . . . . . . . . . 73

11. Distribution of the beluga whale . . . . . . . . . 77

12. Marine mammal food relationships in the Arctic Ocean . . . 81

13. Marine mammal food relationships in the Bering and Chukchi Seas . . . . . . . . . . . . . 82

14. Marine manmal food relationships in the North Pacific Ocean and Gulf of Alaska. . . . . . . . . . 83 
1. Synopsis of marine mammal research and

managment in Alaska .. . . . . . . . . 7

2. Alaska Department of Fish and Game listing

of marine mammals . . . . . . . . . . . 15

3. Harvest of marine mammals in Alaska, 1968-72 . . 98

4. Estimated current take and proposed takings

of marine mammels in waters off Alaska . . . . . 101

5. Estimates of recent takings of marine mammals

in waters off Alaska by foreign nationals . . . 106

6. Incidental catch of northern sea lions by the

Japanese groundfish fishery .......... 108

7. Incidental catch of northern sea lions by the

U.S.S.R. groundfish fishery ......... 109

8. Impact of requested action, if implemented, on activities discussed in this report . . . . . 124

9. Consumption of fish and comparison with standing stocks in the eastern Bering Sea

and Aleutian areas . . . . . . . . . . . 143 
CONSIDERATION OF A WAIVER OF THE MORATORIUM AND RETURN OF MANAGEMENT OF CERTAIN MARINE MAMMALS TO THE STATE OF ALASKA
( ) Draft
(X) Final Environmental Statement

Responsible Federal Agency: Office of Fisheries Management National Marine Fisheries Service NOAA/Department of Commerce

1. Name of Action: (X) Administrative ( ) Legislative

2. Description of Action: The Marine Mammal Protection Act of 1972

(86 Stat. 1027; hereinafter, The Act) imposed a moratorium on the taking and importing of marine mammals and marine mammal products and partially preempted the authority of States to manage marine mammals within their jurisdiction effective December 21, 1972.

The State of Alaska has requested the Secretary of Commerce and the Secretary of the Interior to waive the moratorium on nine species of marine mammals in its jurisdiction and return management to the State. Before such a request can be granted, the Act requires the appropriate Secretary to take the following actions with respect to each species or population stock affected: (1) determine whether or not and to what extent, a waiver of the moratorium is compatible with the Act; (2) promulgate Federal regulations to ensure that any taking will not be to the disadvantage of such species or population stock; and (3) determine that the State's laws and regulations are consistent with the Act and with any Federal regulations.

\section{Summary:}

A. Environmental Impacts: Some environmental impact would result from 
waiving the moratorium and allowing the State of Alaska to resume management of marine mammals in waters off Alaska. Up to $80,1 \neq$ J animals could be taken annually within the limitations of the proposed waiver. However, the actual harvest, based upon the take prior to the Act, probably would not exceed 63,000 animals, including an estimated 23,000 which are now being taken under provisions of the Act for subsistence, research, public display, and incidental to domestic commercial fishing operations.

B. Adverse Environmental Effects: No significant adverse environmental effects are anticipated as a result of the requested action. The harvesting of marine mammals in Alaska under the State laws and regulations (pre-Act) at approximately the same levels did not produce any discernible long-term adverse effect on the well-being of the animal populations or their environment.

4. Alternatives: For each species involved, five alternatives are being considered and compared with the requested action.

A. Continue the moratorium and retain management authority under the Federal Government (no action);

B. Continue the moratorium and transfer management authority to the State of Alaska;

C. Waive the moratorium and retain management authority under the Federal Government;

D. Waive the moratorium and transfer management authority of only selected species to the State of Alaska; and 
E. Waive the moratorium to a lesser or greater extent than proposed.

\section{Comments Solicited on the Draft EIS*:}

Federal agencies

Congressional offices

State and local governments

Representative scientists working with marine mammals

Selected list of individuals and organizations

Alaska Native organizations

Marine Mamma1 Commission

\section{Hearings:}

A. Administrative hearings on the Secretary of the Interior's determination to waive the moratorium on walrus and the proposed regulations were held in Anchorage, Alaska, on March 19-22, 1975, and in Washington, D.C., on April 8-9, 1975.

B. Hearings on the remaining species being proposed for State management were held in 1976 before the Honorable Malcolm P. Littlefield as follows: June 29-July 2 and July 14-20, in Anchorage, Alaska; July 6-9, in Nome, Alaska; July 12-13, in Bethe1, Alaska; and October 19-20, in Washington, D. C.

A number of related hearings have been held in Alaska and elsewhere at which testimony was given concerning marine mammals in Alaska. A summary of these hearings is contained in Appendix B.

\footnotetext{
* Copies of mailing addresses are contained in Appendix A.
} 
7. Draft Statement to CEQ March 5, 1976

Final Statement to $\mathrm{EPA}^{*}$

March 24, 1978

8. Comments Received on the Draft Environmental Impact Statement:

The following organizations submitted comments on the draft statement:

a. Department of Agriculture

b. Department of the Interior

c. California Department of Fish and Game

d. State of Alaska: Department of Environmental Conservation

e. State of Oregon

f. Washington Department of Game

g. National Fisheries Institute

h. University of Alaska: Institute of Arctic Biology (Dr. L. Irving)

i. University of Alaska: Institute of Marine Science (Dr. R. Elsner)

j. University of Alaska: Cooperative Extension Service (J.W. Matthews)

k. Alaska Professional Hunters Association

1. Bering Straits Native Corporation

m. Nunam Kitlutsisti

n. Environmental Defense Fund

o. National Parks \& Conservation Association

p. Committee for Humane Legislation

q. Society for Animal Protective Legislation

r. National Wildlife Federation

s. Safari Club International: Chicago Chapter

t. Safari Club International

u. The Wildife Society 


\section{A. BACKGROUND}

The Marine Mammal Protection Act of 1972, which became effective on December 21, 1972, imposed a moratorium on the taking and importing of all marine mammals and marine mammal products and partially preempted the authority of the States to manage marine mammals within its jurisdiction. The Act divided jurisdiction over species of marine mammals between the Secretary of Commerce for whales, porpoises, seals, and sea lions and the Secretary of the Interior for all others, including polar bears, sea otters, and walruses.

Section 101(a)(3)(A) of the Act provides that this moratorium can be waived to allow the taking or importing of any marine mammal, if, on the basis of the best scientific evidence available and in consultation with the Marine Mammal Commission (MMC), the appropriate Secretary determines that to do so would be compatible with the Act. If a waiver is appropriate, the Secretary is authorized to adopt regulations pursuant to section 103 of the Act to ensure that the resultant taking will not be to the disadvantage of any species or population stock involved.

Section 109 of the Act allows a State to adopt and enforce its laws and regulations relating to the protection and taking of marine mammals if the appropriate Secretary determines that State laws and regulations are consistent with the Act and with any applicable Federal regulations. Before the Act became effective, some marine mammals (and other wildlife and . fish) were managed by the Alaska Department of Fish and Game (ADF\&G), which conducted comprehensive programs of research, management, and enforcement. (Táble 1 is a brief historical review of State and Federal activities in 
research and management of the uine marine mammal species covered by the State's request.)

On January 31, 1973, the State of Alaska (hereinafter the State) requested the Secretary of Commerce, acting through the National Marine Fisheries Service (NMFS), to waive the moratorium with respect to northern (Steller) sea lions, harbor seals (including spotted seals), ringed seals, ribbon seals, bearded seals, and beluga whales and to approve the State's laws and regulations relating to the management of these species. The State submitted a similar request to the Secretary of the Interior, acting through the U.S. Fish and Wildlife Service (FWS), with respect to polar bears, sea otters, and walruses. These requests are contained in appendix C. On April 9, 1976, the Directors of NMFS and FWS proposed to return management of nine species to the State. (See appendix H,) The proposed Federal action under consideration in this document is the waiving of the moratorium, with limitations, on nine species of marine mammals in waters off Alaska. $1 /$ Under the waiver, the State would be granted the authority to regulate takings within state jurisdiction and on the high seas in the waters off Alaska (1) for sport, commercial, and subsistence purposes $\underline{1 \mathrm{a} /}$, and (2) for scientific research within state waters, and (3) for domestic takings incidental to commercial fishing operations. Persons not holding a valid license or permit from the State of Alaska, must obtain a Federal permit before legally taking marine mammals from waters outside State jurisdiction. Permits for public display and permits for incidental takings by foreign vessels inside the U.S. Fishery Conservation Zone will remain with the Federal Government.

$1 /$ See pages ii and 20 for area defined as "waters off Alaska".

la/ Agencies believe that the State has had authority to regulate the take of nondepleted species for subsistence and handicraft purposes, but the State has declined to regulate only one class of takers. 


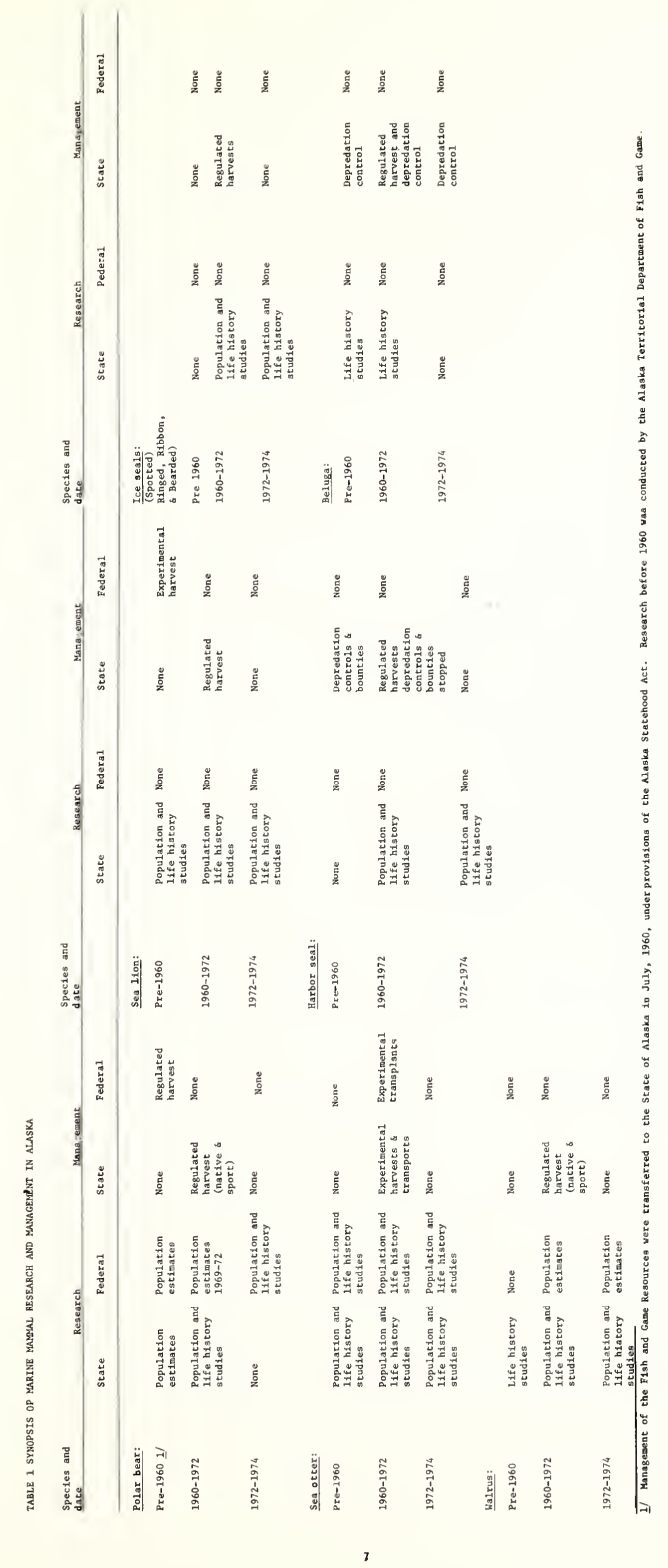


Species of marine mammals other than those nine species requested by the State will remain under the protection of a moratorium, enforced jointly by the Federal Government and the State of Alaska.

The proposed Federal action involves three interrelated components. The first one being the promulgation of Federal regulations pursuant to section 103 of the Act to assure that any taking will not be to the disadvantage of any of the above species. Draft regulations were published on April 9, 1976 (41 F.R. 15166). These regulations defined the extent of the waiver and essentially provided that the laws and regulations of the State of Alaska, once approved, will establish the terms and conditions under which taking will take place.

The second component of the proposed Federal action is to determine that the State's laws and regulations are consistent with the Act and with all Federal regulations, including those adopted pursuant to section 103 of the Act and those setting forth criteria for Federal review of State laws.

The third component of the proposed action is to waive the moratorium established by section 101 of the Act to an extent determined by the respective Secretaries. In briefs filed at the conclusion of the hearing on the record, the NMFS and FWS believed that the following species or stocks of marine mammals could be taken in the waters off Alaska to the limitations given:

$\begin{array}{lrlr}\text { Beluga whale } & 360 & \text { Ribbon seal } & 500 \\ \text { Northern sea lion } & 15,000 & \text { Bearded seal } & 9,000 \\ \text { Harbor seal* } & 14,000 & \text { Polar bear** } & 250 \\ \text { Largha (spotted) seal* } & 15,000 & \text { Sea otter** } & 3,000 \\ \text { Ringed seal } & 20,000 & \text { Walrus** } & 3,000\end{array}$

* Original proposal (41 F.R. 15166) was for a waiver of 6,500 harbor and 20,000 largha seals. ** Retrieved take. 
Section $103(d)$ of the Act requires that the proposed regulations, together with the proposed waiver, be the subject of a formal hearing on the record before an Administrative Law Judge (ALJ). The hearing was held before the Honorable Malcolm P. Littlefield from June 29, 1976, through July 20, 1976, in Anchorage, Nome, and Bethel, Alaska; it then reconvened in Washington, D.C., on October 19-20, 1976. The hearing addressed the following 17 issues of fact and law pertaining to the waiver, which the ALJ identified after a prehearing conference held on May 18, 1976, in Arlington, Virginia. (41 F.R. 21832-32834):

1. The number of separate population stocks, if any, included in each species;

2. The estimated existing population levels of each species and population stock;

3. What is the proper meaning for the term "optimum sustainable population" more specific than is defined in the Act and in accordance therewith what is the optimum sustainable population of each such species and population stock?

4. The anticipated effect on the optimum sustainable population of each species and population stock as well as the health and stability of the ecosystem in waiving the moratorium to the extent proposed; also, including the meaning of the term "incidental take" and what effect, if any, does it have on the optimum sustainable population of each species and population stock?

5. What constitutes a state regulation for purposes of the instant proceeding and will Alaska's laws and regulations, if approved, be enforced as Federal regulations?

6. The humaneness of the methods and means of taking permitted by Alaska's laws and regulations;

7. What are the components of modern scientific resource management program for each of the nine species?

8. Who has the burden of proving that a given population stock or species has diminished below the optimum sustainable population and does Alaska's management program ensure that the extent of the waiver will not be exceeded?

9. Whether the State of Alaska's management program is in accordance 
with sound principles of resource protection and conservation as provided within the purposes and policies of the Act?

10. What criteria establishes that a population stock is disadvantaged under the Act, and in accordance therewith, does the State of Alaska's management program ensure that any takings will not be to the disadvantage of any species or population stock?

11. The adequacy of provisions for public participation within the State of Alaska in the process of implementing the waiver;

12. The adequacy of Federal provisions for monitoring and review of the State of Alaska's program;

13. If the proposed waiver is granted and the delegation takes place, can the Federal Government enforce the provisions of these regulations pursuant to section 105 of the Marine Mammal Protection Act and will the Federal Government as a private landowner be bound by the rules and regulations issued by the State of Alaska; also, will the State of Alaska have authority over non-Alaskan citizens on the high seas?

14. Is the definition of "waters of Alaska" as contained in \$18.94 and $\$ 216.112$ of the proposed regulations consistent with the applicable Federal Acts, treaties, and laws of the bordering state sovereigns, including but not limited to the 200-mile limit Act, as well as are there other treaties governing the subject matter of the instant case and how do they affect the proposed regulations?

15. Whether the proposed waiver, regulations, and delegation abrogates the rights of the Indian, Aleut, and Eskimo Natives, and if so, is this abrogation permissible under existing law?

16. What are the other jurisdictions whose activities affect the same stocks or species as those at issue here, if any, and do sound principles of resource protection and conservation require that those effects be integrated into the state management program? and

17. Should the proposed waiver of moratorium be granted?

On June 30, 1977, the ALJ submitted his recommended decision to the Directors, NMFS and FWS. The ALJ determined, on the basis of the hearing record, that the populations of all nine subject species of marine mammals are within the range of optimum sustainable population and that a waiver of the moratorium and the return of management to the State of Alaska, subject to certain modifications, would be in accord with the requirements of the Marine 
Summarizing, the ALJ made the following findings:

1. The ALJ found that the best scientific evidence available was presented at the hearings in support of the proposed waiver of the moratorium, thus complying with one of the basic preconditions for waiving the moratorium.

2. In waiving the moratorium the Secretaries of Commerce and Interior, in order to protect the stocks in question, must guard against a level of take which may reduce the stocks below their optimum sustainable population (OSP). The ALJ concluded that OSP constitutes a range of population sizes, from a point somewhat above the point of maximum productivity up to the average carrying capacity of the habitat.

3. Notwithstanding the exemption from the moratorium provided for Alaska Natives under Section 101(b) of the Act, regarding the taking of marine mammals for subsistence or Native handicraft purposes, the ALJ concluded that the State may, upon a waiver and return of management, regulate all hunting of marine mammals by Natives.

4. Consistent with the preliminary findings of NMFS in the preamble of the April 9, 1976, proposal to waive the moratorium, the ALJ found that Alaska beluga whales are comprised of two population stocks, one located in the Cook Inlet-Shelikoff Strait and the other located in the Bering Sea-Chukchi Sea, and there are two stocks of polar bears, namely a north and a west stock, but there is only one stock each of land-breeding harbor seals, ice-breeding harbor seals, (1argha or spotted seals), ribbon seals, bearded seals, ringed seals, sea otters, and sea lions in Alaska.

5. The ALJ concluded that the proponents of the waiver have satisfied the burden of proof in establishing that each stock is within the range of OSP.

6. The ALJ found that Alaska's program is in accord with sound principles of resource protection and conservation, including research, enforcement, census, habitat acquisition and improvement, and public participation in the development of game regulations.

7. The ALJ accepted the following population estimates for each of the stocks :

(a) Northern sea lions - 214,000

(b) Beluga whale (Cook Inlet stock) - 500

(c) Beluga whale (Bering-Chukchi Sea stock) - 9,000

(d) Land-breeding harbor seals - 270,000

(e) Ice-breeding harbor seals - 200,000-250,000

(f) Ringed seal - 1 million - 1.5 million

(g) Ribbon sea1 - 90,000-100,000

(h) Pacific bearded sea1 - 300,000-400,000

(i) Polar bear - 6,100-9,200

(j) Sea otter - 100,000-140,000 
8. The ALJ found that the following limits on the annual harvest would protect the stocks from being disadvantaged under the terms of a waiver and return of management:

(a) Northern sea lion - The ALJ recommended setting a harvest limit of 6,648 adults annually, providing that two pups could be taken in lieu of each adult covered by the harvest limit.

(b) Beluga whale (Cook Inlet stock) - The ALJ concluded that 10 belugas could be taken annually without disadvantage to the stock.

(c) Beluga whale (Bering-Chukchi Sea stock) - The ALJ concluded that up to 350 belugas could be safely taken from the stock on an annual basis.

(d) Land-breeding harbor seal - The ALJ found that the total harvest of land-breeding harbor seal adults should not exceed 8,461 . However, in light of the high natural mortality of pups, he further found that two pups could be safely taken in lieu of one adult animal. He added that there should be no taking from the sub-populations in the Outer Kenai Coast, Management Area 3, where there has been heavy exploitation in the past.

(e) Ice-breeding harbor seal - The ALJ found that an annual limit of 5,700 animals would be appropriate in order to avoid disadvantage to the stock.

(f) Ringed seal - The ALJ found that 20,000 ringed seals could be taken annually without disadvantage to the stock.

(g) Ribbon seal - The ALJ found that 500 ribbon seals could be taken annually without disadvantage to the stock.

(h) Pacific bearded seal - The ALJ found that an actual take of 4,000 bearded seals by U.S. citizens, could be taken annually without disadvantage to the stock.

(i) Polar bear - The ALJ found that a take of 170 animals if harvested at the rate of $1 / 3$ from the northern and $2 / 3$ from the western populations annually would not disadvantage the stock.

(j) Sea otter - The ALJ found that a take of 3,000 sea otters annually would not disadvantage the stock but that the take should be restricted to the Rat, Delarof and Andreanof Islands subpopulations.

The ALJ indicated that before the waiver and a return of management is carried out, the State of Alaska should develop detailed regulations which incorporate the fo!lowing points: 
1. "Subsistence takers" should be given preference over sport or commercial hunters, and "subsistence takers" should be defined on the basis of bonafide dependence on marine mammals by coastal residents.

2. The State should exercise extreme caution and prudence, allowing margins for safety, in calculating proposed harvest levels.

3. To prevent the Federal waiver limit from becoming a target, lower figures should be published within the State as harvest quotas, and quotas should be set not only for the total area of the State, but also for each region or village.

4. Persons who conduct commercial harvests should be required to submit jaw and reproductive tract specimens for analysis and research.

5. The State regulations should include specific language corresponding to that in the Act using the standard of OSP.

6. A working arrangement for enforcement of the marine mammal laws should be negotiated between the State of Alaska and the U.S. Coast Guard.

7. A cooperative agreement concerning marine mammal enforcement, monitoring, and review should be negotiated between FWS and NMFS.

8. A working partnership should be established between the Native communities. The ALJ strongly urged that the State provide translations of its proposals so affected Native communities can be fully informed.

9. Proposed changes in laws, regulations, policies, and permits by the State of Akaska should be published in the Federal Register to allow nonAlaskan participation.

10. Whenever seals are to be taken by clubbing, clubbers should be trained, stickers and a backup staff should be used, and seals should be grouped together.

11. The State method for selecting hearing officers in civil prosecution should not be employed for civil prosecutions under Alaska's approved marine mammal regulations. Rather, U.S. Administrative Law Judges should be retained and assigned through the U.S. Civil Service Commission on a case basis with reimbursement being made to the United States Government.

12. Even after a return of management, programs for continuing research and analysis should be pursued to improve the management effort.

13. The ALJ noted that several witnesses had testified that the State system made it difficult for Natives to serve as guides; therefore, most of the profit went to non-Native brokers in Anchorage. This problem should be resolved through appropriate means. 
14. Regulations should provide for the furnishing of necessary data and other information from the State of Alaska to the Marine Mammal Commission.

After taking into consideration the recommendations of the Marine Mammal Commission, the Administrative Law Judge, and a careful review of the hearing record, the Secretaries of the Department of the Interior and the Department of Commerce will make their decision whether it would be appropriate to waive the moratorium and return managementfor nine species (or subspecies) to the State of Alaska. The actual return of management to the State would be subject to State compliance before implementation. Full details would be published in the Federal Register if the Directors decide to waive, which would be followed by State action to comply.

If a waiver is granted, certain requirements would have to be met by the State before management could be returned to the State. For example,

o State laws and regulations must be determined to be consistent with the provisions of the Act, and the terms of the waiver.

o The State would be required to adopt the management principle of osp and change its definition of subsistence take to meet the requirements of the Act.

o The State must prove that it is capable of enforcing quotas, monitoring the catch and assuring quotas will not be exceeded.

o Subsistence takers must be given preference when assessing harvest leve1s.

B. THE SPECIES OF ALASKAN MARINE MAMMALS

The Alaska Department of Fish and Game (1973b) $2 /$ 1isted 28 species occurring in waters off Alaska (Table 2); however, the marine mammal status reports compiled by NMFS (1974) include an additional species, the Pacific whitesided dolphin

\section{(Lagenorhynchus obliquidens).}

2/ The citation for Alaska Department of Fish and Game (1973) will be abbreviated in the remainder of the text to ADF\&G (1973). Because there are two references by $A D F \& G$, the letters $a$ and $b$ will be used to identify the particular documents. 
Table 2 - Alaska Department of Fish and Game 1isting of marine mammals.

Taken from "Animal Reference List", page IX, Alaska Wildlife and Habitat. $(A D F \& G, 1973 b)$

Seals

Bearded Sea1

Elephant Seal

Harbor Seal

Northern Fur SeaI

Ribbon Seal

Ringed Seal

Whales

Baird's Beaked Whale

Beluga Whale

Blue Whale

Bowhead Whale

Cuvier's Whale

Finback Whale

Gray Whale

Humpback Whale

Killer Whale

Minke Whale

Narwhal

North Pacific Right Whale

Pacific Blackfish (Pacific Pilot Whale)

Sei Whale

Stejneger's Beaked Whale

Sperm Whale

Porpoises

Dall Porpoise

Harbor Porpoise

other Marine Mammals

Steller Sea Lion $4 /$

Polar Bear

Sea Otter

Pacific Walrus
Erignathus barbatus

Mirounga leonina

Phoca vitulina

Callorhinus ursinus

Phoca fasciata

Phoca hispida I/

Berardius bairdi

Delphinapterus leucas

Balaenoptera musculus

Balaena mysticetus

Ziphius cavirostris

Balaenoptera physalus

Eschrichtius gibbosus $2 /$

Megaptera novaeang1iae

Orcinus orca

Balaenoptera acutorostrata

Monodon monocerus

Eubalaena glacialis

Globicephala melaena $3 /$

Balaenoptera borealis

Mesoplodon stejnegeri

Physeter catodon

Phocoenoides dalli

Phocoena phocoena

Eumetopias jubata

Ursus maritimus

Enhydra lutris

Odobenus rosmarus

1/ The genus name Pusa is used by NMFS (1974) and by Rice and Scheffer (1968). However, John Burns, principal marine mammal scientist for ADF\&G prefers Phoca (personal communication).

2/ NMFS uses the specific name robustus; Rice and Scheffer (1968) used gibbosus.

3/ This genus and the species within it have undergone extensive revision in the past twenty years. NMFS scientists are using the species name macrorhyncha for the Pacific form. (At the April 1974 meeting of the small cetaceans subcommittee of IWC, the name macrorhynchus, was used.

4/ ADF\&G prefers Steller, NMFS uses Northern. 
The general biology, distribution, migration, and population levels of the nine requested species have been supplied principally by the State and are given in Appendix D. A summary of this information on the population levels and distribution is given as a part of the environmental setting.

The order of listing in subsequent sections of the environmental statement follows the phylogenetic order of precedence and the scientific names given in Rice and Scheffer (1968), the phylogenetic order being: polar bears, sea otters, sea lions, walruses, phocid seals, and toothed whales.

\section{OPTIMUM SUSTAINABLE POPULATION}

Prerequisites to waiving the moratorium are a determination of optimum sustainable population levels for the stocks of marine mammals involved and an indication that management will maintain the stocks at or above these levels. As with most wild stocks of animals, it will be necessary to deal with a range of maximum or minimum values rather than with precise data point estimates.

The Marine Mammal Protection Act of 1972 gives a statutory definition of "optimum sustainable population" (OSP), relating it to productivity, carrying capacity, and ecosystem health. This is a new concept which has not had common usage among scientists, and an explicit operational definition will evolve only with increased analysis and experience.

Since publication of the draft environmental impact statement, the National Marine Fisheries Service proposed and later adopted a definition of OSP. This definition reads as follows: 


\begin{abstract}
"Optimum sustainable population is a population size which falls within a range from the population level of a given species or stock which is the largest supportable within the ecosystem to the population level that results in maximum net productivity. Maximum net productivity is the greatest net annual increment in population numbers or biomass resulting from additions to the population due to reproduction and/ or growth less losses due to natural mortality." (41 F.R. 55536, December 21, 1976).
\end{abstract}

It should be understood, however, that levels of maximum productivity are not permanently fixed points in natural populations, but will vary over time owing to fundamental changes in environmental conditions and other factors independent of man. Also it is extremely difficult to determine either exact population levels of marine mammals in the wild or the vital statistics of these populations. The degree of confidence surrounding such estimates varies with the amount and precision of the available knowledge about any population, the stability of the population and the environment, and other factors.

In this document, we will concern ourselves with the lower level of the range wichin which OSP is more likely to be a critical factor. Since the level of maximum net productivity is difficult to determine accurately, a prudent margin of safety must be applied to protect a stock from declining below its maximum net productivity before such a decline is discovered. Therefore, for each population we will assume that this lower level of population range will be defined by the estimated level of maximum productivity--taking into account a reasonable margin of safety commensurate with the degree of existing scientific knowledge, resiliency of the species, and other factors. 
Although OSP levels are often thought of in terms of absolute numbers of animals, certain indirect indicators are usually more accessible to scientists and may be a more sensitive indicator of the health and vitality of a population than total numbers considered alone. Commonly used indicators relate to such things as extent of distribution in suitable or unsuitable habitat, stability or trends in numbers or relative density in index areas, mortality rates, reproductive rates, and age composition within populations. 


\section{A. THE MARINE ENVIRONMENT--WATERS OFF ALASKA}

The nine species of marine mammals under consideration in this proposal are distributed throughout the waters off Alaska, which for the purposes of this document, are considered to be the eastern North Pacific Ocean and Gulf of Alaska north of 1at. $50^{\circ} \mathrm{N}$. and east of 1ong. $170^{\circ}$ E.; the eastern Bering Sea east of 1ong. $170^{\circ}$ E.; east of the U.S.-U.S.S.R. Convention line of 1867 near the Bering Strait; the Chukchi Sea east of 1ong. $169^{\circ} \mathrm{W}$.; and the Arctic Ocean and Beaufort Sea south of 1at. $75^{\circ} \mathrm{N}$. and between 1ong. $169^{\circ} \mathrm{W}$. and $140^{\circ} \mathrm{W}$. (see frontispiece). The physical characteristics of this area which have the greatest influence on the distribution and population size of Alaskan marine mammals are the extensive continental shelf, the oceanic current systems, and the extensive ice pack and its north-south movement.

The most conspicuous bathymetric feature of the Alaskan marine environment is the continental shelf. This area includes the Queen Charlotte Sound, southeastern Alaska (Alexander) Archipelago, Prince William Sound, Cook Inlet, and the eastern Bering Sea, where the shelf reaches a width of over $500 \mathrm{~km}$. The continental shelf of the eastern Pacific Ocean and eastern Bering Sea is an important component in the production of fish and consequently, to marine mammals.

Gulland (1971), in an adaption from Alverson and others (1964), reported the following approximate areas of continental shelf in the North Pacific: 
Locale

British Columbiasoutheast Alaska

Gulf of Alaska

Alaska Peninsula

Southeast Bering Sea

Northeast Bering Sea
Area $\left(\mathrm{km}^{2}\right)$ of shelf at

depth of $0-300$ fathoms

$$
\begin{array}{r}
103,700 \\
125,700 \\
97,200 \\
322,500 \\
1,0400,000 \\
\hline 049,100
\end{array}
$$

The continental shelf continues on into the Chukchi and Beaufort Seas.

Ocean currents are driven primarily through the action of local wind stress on the sea surface. The Subarctic Current System is the major transpacific eastward flow in the northeastern Pacific Ocean and forms a southern boundary to the waters off Alaska (Fig. 1). The divergence of this current off the coasts of British Columbia and southeastern Alaska is the main influence on environmental conditions in the Gulf of Alaska and Bering Sea. The northward extension of this flow along the Alaska Current System and through the Aleutian-Commander Island arc has a modifying effect on conditions in the western Pacific Ocean and eastern Bering Sea. The southward flow forms the California Current.

In the northern Bering Sea, ice usually forms in October and spreads rapidly southward, usua11y attaining its maximum extent in February. During the winter, ice is present throughout the northern half of the Bering Sea and covers the entire Okhotsk Sea. By July, it is found only in the Gulf of Anadyr and in the Bering Strait. In July and August, all ice disappears in these areas, and open water is present northward of Bering Strait.

Ice conditions in the Chukchi Sea not only depend on the season but may vary greatly from year to year. Ice covers the Chukchi Sea for most of the year, except for August and September when the southern parts become completely free 


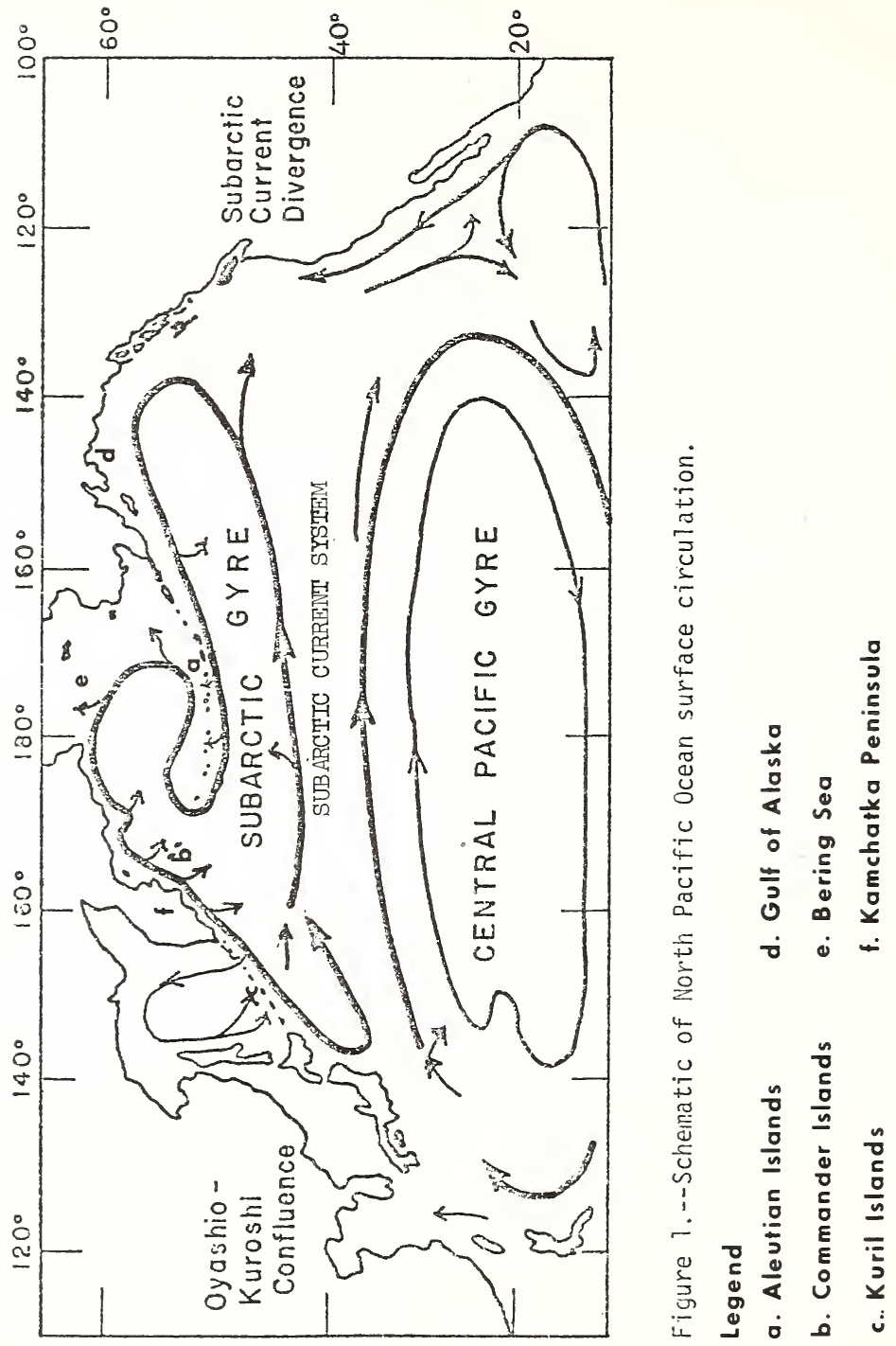


of ice. Winter ice, less than 1 year in age, and polar pack ice from the Arctic Ocean are prevalent in all but the extreme southern portions of the Chukchi Sea throughout the year. The northerly setting current in the Bering Strait usually keeps the Alaskan coast of the Chukchi Sea ice free throughout September as far north as Cape Lisburne. Ice formation and growth proceed rapidly in October, and ship movement is usually not feasible north of the Bering Strait after the middle of October.

The waters of the Beaufort Sea are also dominated most of the year by winter ice (less than 1 year old) and polar pack ice which includes heavy drift ice from the Arctic Ocean. The inshore areas of the Beaufort Sea are generally free of ice during summer months, but the condition of the waterway is strongly dependent upon favorable winds. Heavy pack ice begins to close in by the middle of September, and by mid-October the Beaufort Sea waterway has frozen over.

\section{B. THE FOOD WEB IN WATERS OFF ALASKA}

The eastern Bering Sea is useful as an illustration of the productivity of waters in this area because (1) stocks of pinnipeds are large, (2) extremely heavy fishing occurs there, and (3) data exist for making estimates on productivity through the food web.

A brief summary is presented here of the food chain in the eastern Bering Sea. The more detailed information from which this has been extracted was discussed by Takenouti and others (1972).

The food web is complex in the eastern Bering Sea. Although much of the primary productivity of phytoplankton takes place in the water column, blooms of algae 
in and beneath the sea ice in late winter (McRay and others, 1972) and epibenthic algae growing on mud flats in summer contribute to the overall primary production of the area. Many animals, including fishes and pinnipeds, feed on both benthic and pelagic organisms, and it is difficult to assess the relative importance of each. Although some progress has been made in understanding the amount of primary production in the water column (McRoy and others, 1972)-which can be used as a basis to estimate overall productivity--the relationships between pelagic, in-ice, and benthic biospheres are not understood.

Feedback mechanisms involving microbial action operate to recycle organic matter back to phytoplankton. In some instances, animals may prey on other animals that are above or below them in the food chain (Sanger, 1974). For example, in a gammarid amphipod-juvenile pollock-baleen whale chain, the gammarids being both omnivore and scavenger, will not only be consumed by the pollock and whale, but will itself feed upon the dead whale carcass. Figure 2, adapted by Sanger (1974) from Dunbar (1953), illustrates this principle of feedback and recycling mechanisms and existence of multiple feeding levels; it also demonstrates the aptness of the term "food web" to describe the interconnecting predator-prey structure that exists in most oceanic ecosystems.

The assumption of a simple food chain provides an expedient, but rough means of deriving production estimates to arrive at estimated biological production in a system. Recently Sanger (1972a) estimated biological productivity and fishery potentials in the subarctic Pacific region. Although the method is as yet untested, the resultant estimates have not been inconsistent with harvest data, and they may have provided a framework for decision concerning harvest quotas and research strategies. 


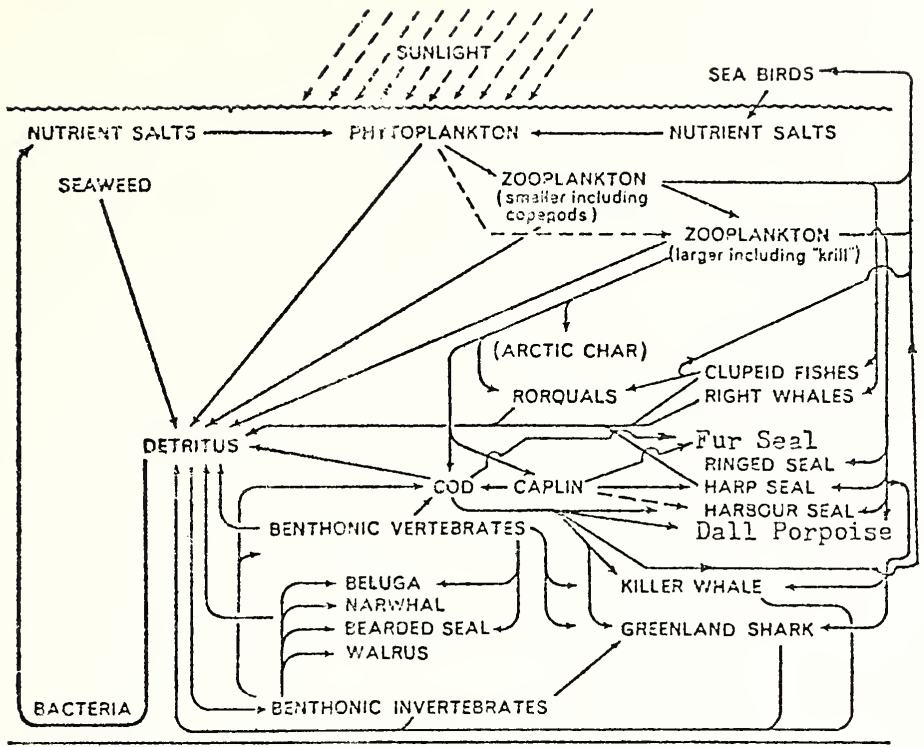

Fig. 2 The biological cycle in the arctic and subarctic marine zores, somewhat simplified. The prey-predator system illustrated in the right-hand three-quarters of the figure ends firally in the production of organic detritus, which is decomposed by the bacierial action mainly on the sea-floor in moderate depths. The resulting supply of inorganic plane nutrients (nitrates, phosphates) is returned to the surface by vertical water exchange in the aurumn and winter, and is thus ayailable for the regeneration of the phytoplankton population in the springtime conditions of increasing sunlight.

Modiried aiter Dunbar (1953). 
The term "trophic level" has been applied to the concept of various food organisms of a certain link of the food chain that provides the food energy to the next higher link. Energy bound in the organism (measured by means of the amount of carbon involved) is passed on to higher levels. This trophic level concept simplifies the food chain system by lumping organisms with similar food habits regardless of size. In his recent study, Sanger (1974) used the term "transfer coefficient," defined as the portion (percent) of the production at one particular trophic level that is produced at the next higher trophic level.

"Production" is the net weight, or biomass, produced per unit of time. Data for several years from Ocean Station Papa (McAllister 1969, 1972) averaged about 26 percent production of herbivorous zooplankton from phytoplankton. We will follow Sanger's example (1974) and use 26 percent for the first two trophic levels, and 10 percent for the higher levels as has been used by various authors. One of the problems involved in food chain studies and productivity is the uncertainty about the number of trophic levels in any community. Sanger stated that in reality there is an infinite number of trophic levels, and what is used in calculations as a trophic level may be thought of as representing the average production over a range of organisms.

In order to complete the food chain to include marine mammals, a biomass estimate is needed of the three vertebrate groups that together comprise the second through the fourth degree carnivores. These are marine finfish, sea birds, and marine.mammals. (Although larger squid are top carnivores, they are ignored here.) 
Marine finfish.--Sanger (1972a) estimated fish production in the subarctic Pacific region to be 52 million tons per year by assuming that two-thirds of the secondary carnivores are fish.

Assuming that approximately half of these fish are produced in the eastern half of the region, the combined eastern North Pacific-Bering Sea production of fish would be 26 million tons per year. Alverson and others (1964) estimated the standing crop of demersal fish for the continental shelf area of the easter n North Pacific-Bering Sea by utilizing exploratory trawl catch rates. Estimates of total standing crop of all species of demersal fish calculated for coastal regions on depth intervals are shown below:

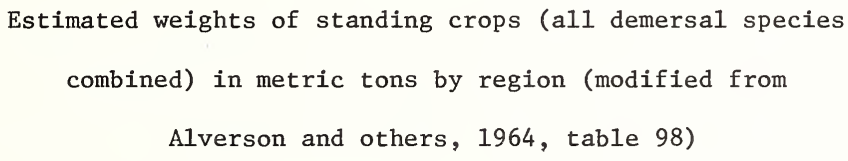

Region

British Columbia--southeastern Alaska Alaska Peninsula Gulf of Alaska Eastern Bering Sea Total

$$
\begin{array}{rr}
\frac{\text { Metric tons }}{1,556,000} & \text { Metric tons } \\
1,217,000 & 2,773,000 \\
& 691,000 \\
& \frac{6,485,000}{9,949,000}
\end{array}
$$

The estimates of potential catches from the northwest Pacific (southeast Alaska, Gulf of Alaska, and Bering Sea) made by Gulland (1971) total over 4,110,000 metric tons of fish and other organisms, excluding crustaceans. However, present-day harvests are in the range of 2,300,000 metric tons per year. These estimates are shown in the table below with the general area indicated for each. 
Estimates of fish production and

harvestable stocks of fish

Estimator

Sanger (1972a)

(1974)

Alverson and others (1964)

Gulland (1971)
Quantity in thousand tons

52,000 (production)

26,000 (production)

9,045 (standing crop, demersa1)

4,110 (harvestable demersal and pelagic)
Area Covered

N. Pacific-Bering Sea

E.N. Pacific-E. Bering Sea

E.N. Pacific-E. Bering Sea (out to 300 fathoms)

E.N. Pacific-E. Bering Sea

Sea birds and marine mammals.--Gross numbers and biomass of pelagic sea birds in the subarctic Pacific region were estimated by Sanger (1972b). He obtained observation data from cruises of research vessels from which he calculated numbers and weights of birds. His resulting estimates are summarized below:

Estimated biomass, in metric tons, of pelagic sea birds in the subarctic Pacific region (from Sanger, 1972b)

$\underline{\text { Domain }}$

Coasta1

Bering Sea Coastal

Central Subarctic

$\begin{array}{lcc}\text { Summer } & \text { Season } & \text { Average } \\ 6,510.8 & \underline{\text { Winter }} & \\ 6.510 .8 & 856.8 & 3,683.8 \\ 9,150.8 & --1,265.0 & 3,255.4 \\ & 1,207.9\end{array}$

Estimates of the quantities of food consumed by pinnipeds show a total food comsumption by fur seals, hair seals, and sea lions of 4,133,000 metric tons annually on the Bering Sea shelf (NMFS, 1975). Of this, an estimated 2,090,000 metric tons were finfish (NMFS, 1975). 


\section{BIOLOGY AND OPTIMUM SUSTAINABLE POPULATION ESTIMATES OF IMPACTED MARINE MAMMALS}

\section{Polar Bear (Ursus maritimus)}

\section{Distribution}

Polar bears occur only in the Northern Hemisphere, nearly always in association with Arctic sea ice. Centers for six geographically isolated polar bear populations which have been identified in the main polar basin are Wrange1 Island-western Alaska, northern Alaska, northern Canada, Greenland, Spitsbergen-Franz Josef Land, and central Siberia. Separate populations also occur further south in Hudson Bay in Canada. Bears are most abundant near the southern edge of the sea ice but do occur throughout most of the polar basin and have been recorded as far north as lat. $88^{\circ} \mathrm{N}$. They make extensive north-south movements related to the seasonal position of the southern edge of the ice. In winter, bears off Alaska commonly occur as far south as the Bering Strait and occasionally reach St. Lawrence Island and even St. Matthew Island in the Bering Sea. In the summer, bears commonly occur along the edge of the ice pack north of Alaska, between 1 at. $71^{\circ}$ and $72^{\circ} \mathrm{N}$. Pregnant females concentrate for winter denning and bearing young on certain large offshore islands in the U.S.S.R., Canada, and Spitsbergen, but they also den on the pack ice adjacent to and along Alaska's Arctic coast (ADF\&G, 1973a). Distribution of the polar bear in Alaska is shown in figure 3 .

\section{Populations}

Total world population estimates, which range from a low of 10,000 by the Soviets to a high of 20,000 by the Norwegians, are based on broad assumptions and should be considered as very general. Abundance of bears off the Alaska 


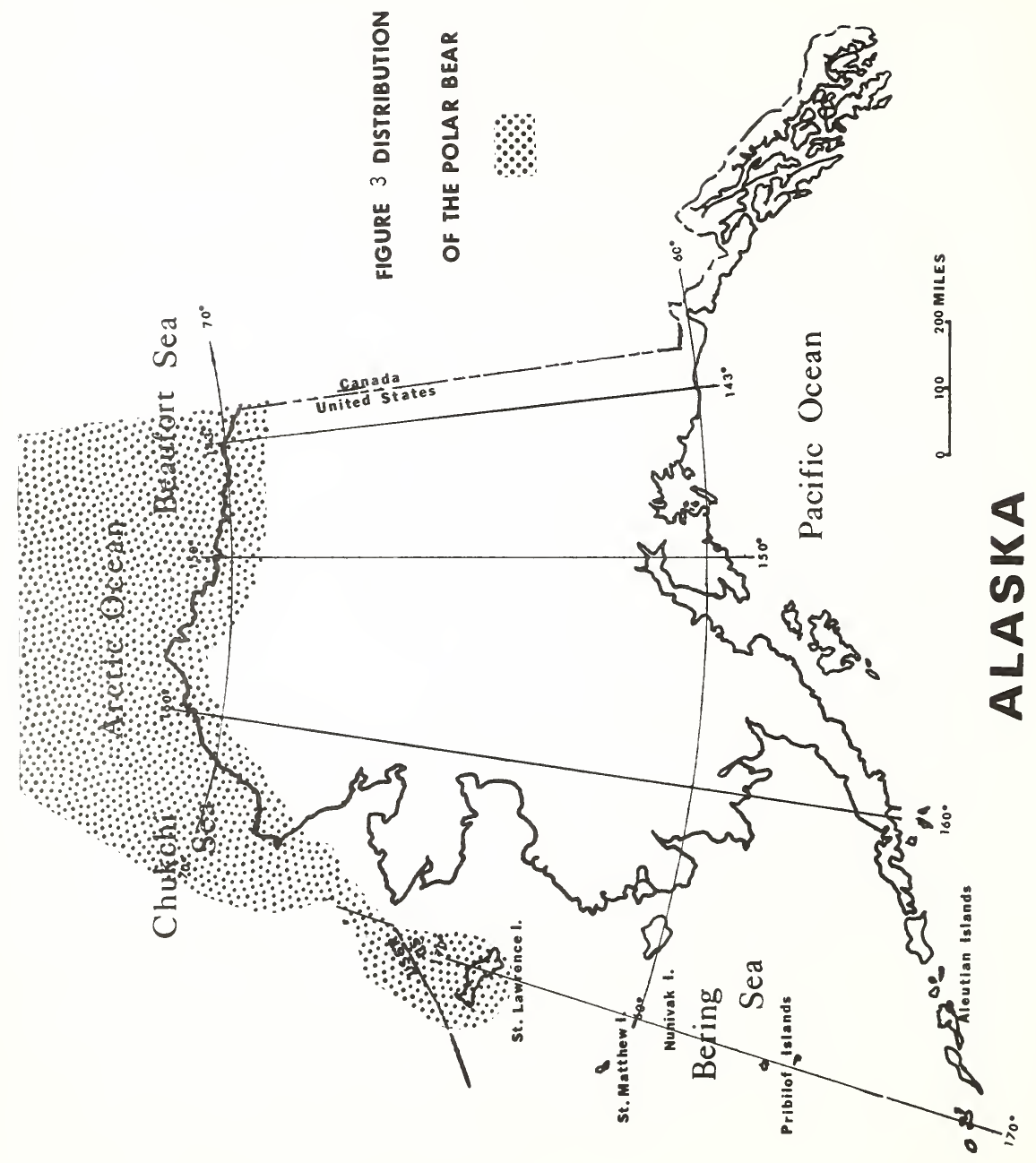


coast and the magnitude of sustained long-term harvests suggest that the 20,000 figure may be too low.

Brooks (1970) estimated the numbers of polar bears in Alaskan waters to be 4,900; however, this figure did not encompass all population stocks. Lentfer (1973) concluded that bears west of Alaska and bears north of Alaska form essentially discrete populations (population stocks as defined in the Act). He based this on recovery of tagged animals, body and size differences, and differences in mercury accumulation in bears from the two areas. Lentfer's testimony at the 1976 ALJ hearings, as reported in the ALJ's recommended decision (1977)*, suggests that the polar bear population stock of the Chukchi Sea (Wrangell Island to western Alaska) numbers about 7,000 (ALJ, 1977, p. 78); the stock to the north of Alaska.(Beaufort Sea to Banks Island), about 2,500 (ALJ, 1977, p. 79). Chapman, of the Marine Mamma1 Commission (testimony, 1976), suggested that the total population ranges from 5,500 to 5,700 (ALJ, 1977, p. 80),

\section{Carrying Capacity}

Polar bear population stocks appear to be at high levels and may be near the carrying capacity of the habitat. This is indicated by the relative number of polar bears seen each year, their geographical distribution, and other population characteristics.

Extensive capture and tagging studies by FWS and ADF\&G investigators show that bears are well distributed throughout their historical range off

\footnotetext{
*Testimony presented during the ALJ hearings, as reported in his recommended decision issued on June 30, 1977, will be cited throughout this document by the named source of the information, followed by "testimony, 1976" in parentheses. The ALJ's recommended decision will be cited as (ALJ, 1977).
} 
Alaska (Lentfer, testimony, 1976). The number of bears reported per hour of flying by Alaska hunting guides did not show a trend during 1956-59.

Sex composition of bears taken from 1961-72, when 87 percent were taken with the use of aircraft, was 70-80 percent males. Selective hunting with use of aircraft reduced the percentage of mature males in the population. A high percentage of females with young in therpopulation indicated a healthy rate of reproduction. The age composition of bears harvested west of Alaska during the aircraft hunting era did not show a trend. Age composition of bears harvested north of Alaska declined in 1970 and 1971 and then increased in 1972 (ADF\&G, 1973a). This reflected the high harvest level during 1966-67 followed by hunting restrictions after 1967 .

\section{$\underline{\text { Productivity }}$}

On the basis of tagging results for 631 animals, Lentfer (1972) found that females with young make up 19 percent of the population. The U.S. Fish and Wildife Service (1974) stated that a litter of two is common; one, less common; and three, rare. Females breed again at about the time they separate from their young, so normally they can produce 1 ftters every third year. Females can first breed at ages 3 or 4 and males at 4 , but some animals are older at first breeding. Most bears do not live beyond 25 years.

The estimated composition for northern and western populations, based on data for 901 polar bears tagged off Alaska between 1967 and 1976, is given below (Lentfer, exhibit FWS 19, cited in ALJ, 1977, p. 79). 
Estimated composition of north area Alaska polar bear population, based on University of Colorado simulation computer modeling using data from 901 animals captured for mark and recovery, 1967-76

$\begin{array}{lrrr}\begin{array}{l}\text { Age } \\ \text { Class }\end{array} & \text { Males } & \begin{array}{c}\text { Females } \\ \text { yoth }\end{array} & \begin{array}{c}\text { Both } \\ \text { sexes }\end{array} \\ 1 & 211 & 227 & 438 \\ 2 & 181 & 178 & 359 \\ 3 & 128 & 167 & 295 \\ 4 & 80 & 142 & 222 \\ 5 & 68 & 120 & 188 \\ 6 & 56 & 100 & 156 \\ 7 & 47 & 84 & 131 \\ 8 & 44 & 79 & 123 \\ 9 & 37 & 65 & 102 \\ 10 & 31 & 55 & 86 \\ 11 & 26 & 48 & 74 \\ 12 & 22 & 40 & 62 \\ 13 & 21 & 38 & 59 \\ 14 & 20 & 35 & 55 \\ 15 & 16 & 29 & 35 \\ 16 & 11 & 21 & 18 \\ 17 & 7 & 11 & 14 \\ 18 & 6 & 8 & 10 \\ 19 & 4 & 6 & 2,476 \\ 20+ & 3 & 4 & \end{array}$

Estimated composition of west area Alaska polar bear population, based on University of Colorado simulation computer modeling using data from 901 animals captured for mark and recovery, 1976-76

\begin{tabular}{lrrr}
$\begin{array}{l}\text { Age } \\
\text { Class }\end{array}$ & Males & Females & $\begin{array}{r}\text { Both } \\
\text { sexes }\end{array}$ \\
\cline { 2 - 3 } 1 & 573 & 616 & 1,189 \\
2 & 491 & 483 & 974 \\
3 & 347 & 453 & 800 \\
4 & 218 & 387 & 605 \\
5 & 185 & 326 & 511 \\
6 & 151 & 272 & 423 \\
7 & 128 & 228 & 356 \\
8 & 121 & 215 & 336 \\
9 & 100 & 175 & 275 \\
10 & 85 & 150 & 235
\end{tabular}




\begin{tabular}{lrrr}
$\begin{array}{l}\text { Age } \\
\text { Class }\end{array}$ & Males & Females & $\begin{array}{c}\text { Both } \\
\text { sexes }\end{array}$ \\
\hline 11 & $\frac{130}{202}$ & 168 \\
12 & 60 & 108 & 161 \\
13 & 58 & 103 & 147 \\
14 & 53 & 94 & 121 \\
15 & 43 & 78 & 87 \\
16 & 31 & 56 & 47 \\
17 & 18 & 29 & 40 \\
18 & 17 & 23 & 27 \\
19 & 11 & 16 & 20 \\
$20+$ & 11 & 9,951 & 6,724
\end{tabular}

Food Habits

Polar bears feed primarily on ringed seals and also on bearded seals, harp seals, and hooded seals. They frequently eat carrion, including whale, walrus, and sea1 carcasses, and small mammals, birds, eggs, and vegetation when other food is not available (FWS, 1974).

\section{Optimum Sustainable Population}

The population stocks off Alaska are exhibiting several characteristics which indicate that they are at relatively high levels.

Between 1961 and 1972, an average of 260 bears per year where harvested; 70 to 80 percent of this harvest were old-age males, but since one male may mate with several females in a single season, it is estimated that sufficient males remained to breed all available females, and the impact of this level of harvest on population numbers has been slight (ADF\&G, 1973a).

The number of bears seen per hour of flying by Alaskan hunting guides has not indicated a change in population size since 1956 (Lentfer, 1972).

The Soviets believe that polar bear populations in the Soviet Arctic, which includes the Wrange11 Island-western Alaska population stock, declined during 
the first half of this century but have now recovered and stabllized(ADF\&G, 1973a).

Extensive capture and tagging studies by FWS and ADF\&G investigators show that bears are well distributed throughout their historical range in waters off Alaska. More bears are now being observed in areas near the coast, and a significant number of maternity dens are again being found on mainland Alaska. It is not certain that this wholly represents an increase in the number of bears in the populations. The lack of disturbance by low flying small aircraft since the ban on use of aircraft for hunting and since cessation of sport hunting by the Act might also be a factor in this distribution pattern.

These biological characteristics are indicators that these population stocks are at relatively high levels. ADF\&G (written communication, June 25, 1975) estimated both of the population stocks to be within the range of OSP. Lentfer (testimony, 1976) believed that the bears of both populations are near carrying capacity and well within the range of OSP (ALJ, 1977, p. 81).

\section{Sea Otter (Enhydra 1utris)}

\section{World Distribution}

Sea otters once occupied the coastal waters of the North Pacific rim from the vicinity of Moro Hermoso on the Pacific side of Baja California northward to Prince William Sound, Alaska; then westward through the Aleutian, Pribilof, and Commander Islands; and southward along the southern Kamchatka Peninsụla and the Kurile Islands to the north side of Hokkaido Island, Japan. Between 1742 and 1911, commercial fur hunters reduced sea otters to an extremely low 
population level. The present populations grew out of small nuclei remaining in California, Prince William Sound, Afognak Island, the Alaska Peninsula, Sanak Island, Sandman Reefs, Bristol Bay, the Andreanof Islands, Rat Islands, Medney Island, and the Kurile Islands (ADF\&G, 1973a).

Alaska Distribution

Small transplanted populations exist in several parts of southeast Alaska, between Dixon Entrance and Yakutat Bay. From Cape St. Elias west, sea otters now occupy almost all of their former range, although the populations are still sparse in some areas. Major concentrations exist in Prince William Sound, along the Kenai Peninsula, Afognak Island, Kamishak Bay, the Shumagin Islands, Sanak Island, Sandman Reefs, and southern Bristol Bay.

In the Aleutian Islands, small numbers are scattered throughout the Fox Islands; few or none are in the Islands of Four Mountains; large populations are found throughout the Andreanof, Delarof, and Rat Islands; and smaller numbers exist in the Near Islands. A small transplanted population is in the Pribilof Islands. Distribution of the sea otter in Alaskan waters is shown in figure 4.

In the waters of the Soviet Union, otters are found in most parts of their former range, which includes the Commander Islands, along the southern tip of the Kamchatka Peninsula, and in the Kurile Islands (ADF\&G, 1973a).

\section{.Population}

In 1956, on the basis of aerial surveys the Alaska sea otter population was estimated at about 25,000 animals and was considered to be increasing at about 4 to 5 percent per year; the world population was estimated at 32,000 to 35,000 animals (Kenyon, 1969). In 1970 after additional 


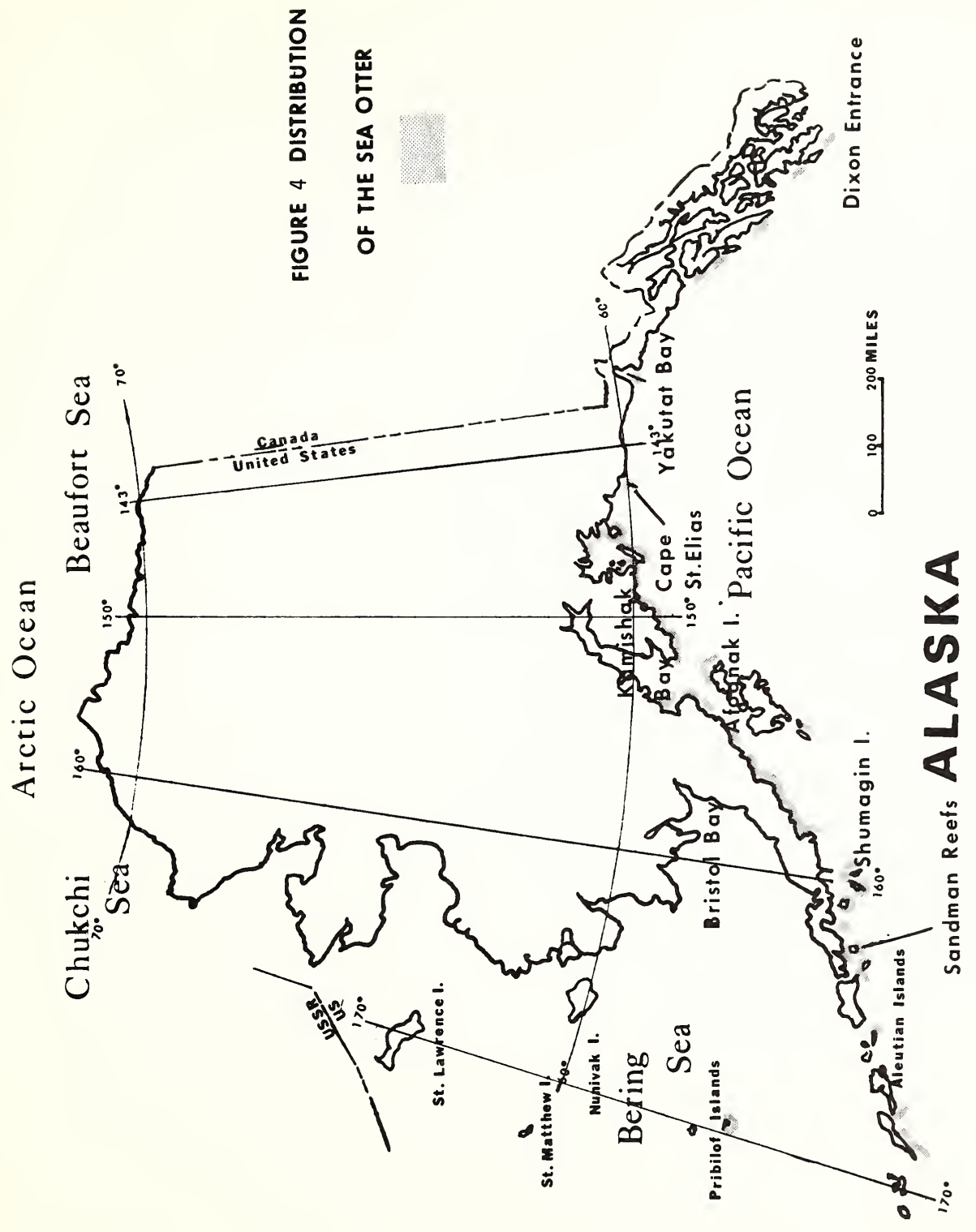


surveys, the Alaska population estimate was 50,000 (FWS, 1974). In 1972, on the basis of refined techniques and additional surveys the Alaska population was estimated at 100,000 to 125,000 animals and still increasing (Schneider, 1973).

The sea otter has received a high measure of protection by both Federal and State laws since 1911 and is not presently subject to any aboriginal hunting. Prior to 1741, a large coastal native population had exploited the sea otter for some thousands of years. The sea otter today, where it has repopulated habitat left vacant by 18 th and 19 th century exploitation, is probably more abundant than it has been for centuries (Laughlin, 1970, and Laughlin and Reeder, 1962).

Otters from Amchitka Island and Prince William Sound were transplanted to the following locations: southeastern Alaska in 1965, 1966, 1968, and 1969 (total 413); British Columbia in 1969, 1970, and 1972 (total 89); Washington in 1969 and 1970 (total 59); Oregon in 1970 and 1971 (total 93); and the Pribilof Islands in 1959 and 1968 (total 64). Among transplanted 3/ otters, young have been observed in southeastern Alaska (J.. S. Vania, written communication, 1973); British Columbia (M. J. Bigg, cited in R. A. Rausch, written communication, December 4, 1973); and Oregon (Jamison, 1973).

3/ All transplant figures from J. S. Vania are contained in unpublished reports of the Alaska Department of Fish and Game, annual reports of the Marine Mammal Committee of the American Society of Mammalogists, 1965-73. 
The pattern of repopulation of sea otter habitat (Kenyon, 1969)

indicates that the entire North American population could

reasonably be considered to be a single genetic stock. For management

purposes, sea otters inhabiting waters off Alaska can be grouped

into the following population stocks (Schneider, exhibit FWS 15, cited in ALJ, 1977, p. 86).

\section{Population stocks}

Near Islands

Rat Islands-Delarof Islands

Andreanof Islands

Islands of Four Mountains

Fox and Krenitzin Islands

North of Unimak Island and the Alaska Peninsula

Pribilof Islands

Sanak Island and Sandman Reefs

Shumagin Islands

Sutwick-Kujulik

Kamishak Bay-Katmai

Kodiak Archipelago

Kenai Peninsula

Prince William Sound-

Kayak Island

Southeastern Alaska
Population estimates

500

$23,000-32,000$

$32,000-40,000$

Few

$600-1,200$

$5,000-10,000$

Less than 25

$6,000-10,000$

$8,000-10,000$

$8,000-10,000$

$$
1,000
$$

4,000-6,000

$1,500-2,500$

$4,000-6,000$

$600-800$ 


\section{Carrying Capacity}

The only practical method of estimating the carrying capacity of a sea otter habitat is to estimate the densities that are found in areas where the population appears to have stabilized. Carrying capacity may change with time as the result of factors including the impact of the sea otters on the ecosystem. There are, however, problems with estimating sea otter numbers over large areas, and there is no good way to compare sea otter habitats (Schneider, testimony,1976).

The most recent information, collected at Amchitka Island, indicates that sea otters may attain densities of 70 otters per square mile of habitat, which is defined as all waters less than 30 fathoms deep. Densities may be even higher in localized areas. Some expanding populations may contain higher densities for a short time, but these are above carrying capacity (Schneider, testimony, 1976).

At the present time, only those population stocks in the Rat IslandsDelarof Islands and Andreanof Islands are considered to be at carrying capacity, and the number of sea otters there now probably approximate the long-term carrying capacity of the area. Other areas throughout the State, such as Montague Island, may be supporting carrying capacity populations, but it would be safer to allow more time for sea otter numbers to stabilize over large areas before any conclusions are drawn (Schneider, testimony, 1976).

\section{Productivity}

Several estimates of the productivity (numbers of animals added to the population yearly) of sea otter populations have been made. Barabash- 
Nikiforov (1947) estimated the rate at 7-10 percent in the Commander Islands; however, Markov (1965) felt the rate of increase for the same population was 30 percent. Estimates by U.S. scientists have been intermediate: 19 percent by Lensink (1962) and 14-15 percent by Kenyon (1969).

A number of aspects of sea otter reproduction are well documented. About half the females 4 years old and older bear a pup each year. The sex ratio is imbalanced in favor of females, probably by a ratio of 40 males to 60 females. If only two-thirds of the females are sexually mature, the annual rate of reproduction would be 20 percent. Field counts have generally ranged between 10 and 25 pups per 100 adults and subadults, except in several transplanted populations where 30 pups per 100 adults and subadults have been observed (ADF\&G,1975).

Once a population reaches a density at which food becomes limiting, large numbers of subadults, 9 to 12 months old, begin to die from disease and malnutrition, particularly in late winter. Adult survival usually remains high, and many otters attain ages of 15 to 20 years (Kenyon, 1969).

\section{Food Habits}

The primary foods of sea otters are clams, mussels, snails, abalone, sea urchins, crabs, octopus, and (in areas where invertebrate populations have been reduced) slow-moving bottom fish. A sea otter eats 20 to 25 percent of its weight in solid food, excluding shells and viscera, each day. For adults, this amounts to 8 to 15 pounds of fresh food per otter per day, or over 180 tons of food per square mile containing 100 sea otters each year $(A D F \& G, 1973 b)$. The abundance of food is the primary factor limiting most sea otter populations. Anything influencing this abundance will affect 
sea otter numbers (AGF\&G, 1973a).

Predation by sea otters influences certain invertebrate populations; thus, the ecology of areas now unoccupied by sea otters will be altered substantially if sea otters become abundant in them. Such changes have not been studied in great detail, but one major effect is a reduction of the age structure of sea urchin populations. This, in turn, reduces grazing by urchins on kelp and allows greater formation of kelp beds (Estes and Palmisano, 1974).

\section{Optimum Sustainable Population}

Sea otters in the Rat Islands-Delarof Islands and in the Andreanof Islands subpopulations are exhibiting several characteristics which indicate that those populations are at or near the carrying capacity of their habitat. (See Schneider, exhibit FWS 15, cited in ALJ, 1977, p. 86).

The rate of productivity in a healthy expanding population has been estimated to range between 10 and 30 percent. Recently the rate has shown a decline. On Amchitka Island, otter productivity is now about 2-5 percent. In the Delarof Islands, it is 4-5 percent annually (Kenyon, 1969). Between 1936 and 1965, the number of animals per square mile has decreased from 30 to 15 on Rat Island and from 42 to 19 on Amchitka Island, and the Andreanof Island subpopulation has shown a similar pattern. The habitat of these groups of islands is now completely occupied, and these populations are no longer contributing to expansion into other areas. Mortality has been found to be high, particularly among the young and the older age classes (Kenyon, 1969).

The population level at which maximum productivity occurred in these subpopulations is not precisely known; however, analysis of Kenyon's 
investigations of the sea otters at Amchitka indicates that it occurred there when the population was at about 3,000 animals. The maximum population at Amchitka Island has been variously estimated between 10,000 and 12,000 animals. Maximum productivity for the entire Rat Island-Delarof Island population stock is not known. However, ADF\&G (1975) estimated that both of these subpopulations are at the upper range of their OSP.

$$
\text { Northern (Steller) Sea Lion (Eumetopias jubatus) } 4 /
$$

\section{Distribution}

Northern sea lions are found along the west coast of North America from southern California to the Aleutian Islands and in the Bering Sea. They also occur along the Kamchatka Peninsula in the U.S.S.R. and southward to the northern islands of Japan. In Alaska, they are most abundant along the Aleutian Islands, Alaska Peninsula, and Kodiak Island. They are abundant along the Kenai Peninsula, Prince William Sound, and southeast Alaska (ADF\&G, 1973a).

4/The ADF\&G prefers the common name "Steller" whereas the MMFS uses the common name "Northern." 
Northern sea lions are normally found in association with land; however, in recent years large numbers of the animals have been wintering along the edge of the sea ice in the Bering Sea (ADF\&G, 1973b). Distribution of sea lions in Alaskan waters is shown in figure 5.

\section{$\underline{\text { Population }}$}

On the basis of aerial surveys, Kenyon and Rice (1961) estimated the world population of northern sea lions to be $240,000-300,000$ in 1961 . In Alaska itself, there are 202 known rookeries and hauling grounds, and estimates of the numbers occupying these--obtained from aerial photographs-indicated a population size exceeding 200,000 (ADF\&G, 1973b). The $A D F \& G$ (1973a) has grouped together rookeries in the following geographic areas for management purposes:

\begin{tabular}{|c|c|c|}
\hline Rookeries* & Geographic area & $\begin{array}{l}\text { Estimated } \\
\text { population }\end{array}$ \\
\hline 1 through 135 & Aleutian Islands-west area & 63,987 \\
\hline 140 through 168 & Aleutian Islands-east area & 46,663 \\
\hline $200,201,295,196,297,298$ & $\begin{array}{l}\text { Bristol Bay area (includes north } \\
\text { side of Alaska Peninsula) }\end{array}$ & 2,700 \\
\hline 285 through 291 & Pribilof Island area & 9,050 \\
\hline $\begin{array}{l}172 \text { to } 192 \text { (exclude } \\
200-201) 205 \text { to } 241\end{array}$ & Alaska Peninsula south side & 25,944 \\
\hline $\begin{array}{l}245 \text { to } 268 \\
320 \text { to } 329\end{array}$ & Kodiak Island & 36,885 \\
\hline 335 to 390 & Kenai-Prince William Sound area & 20,480 \\
\hline 395 to 441 & Southeast & 8,660 \\
\hline Total & & 214,369 \\
\hline
\end{tabular}




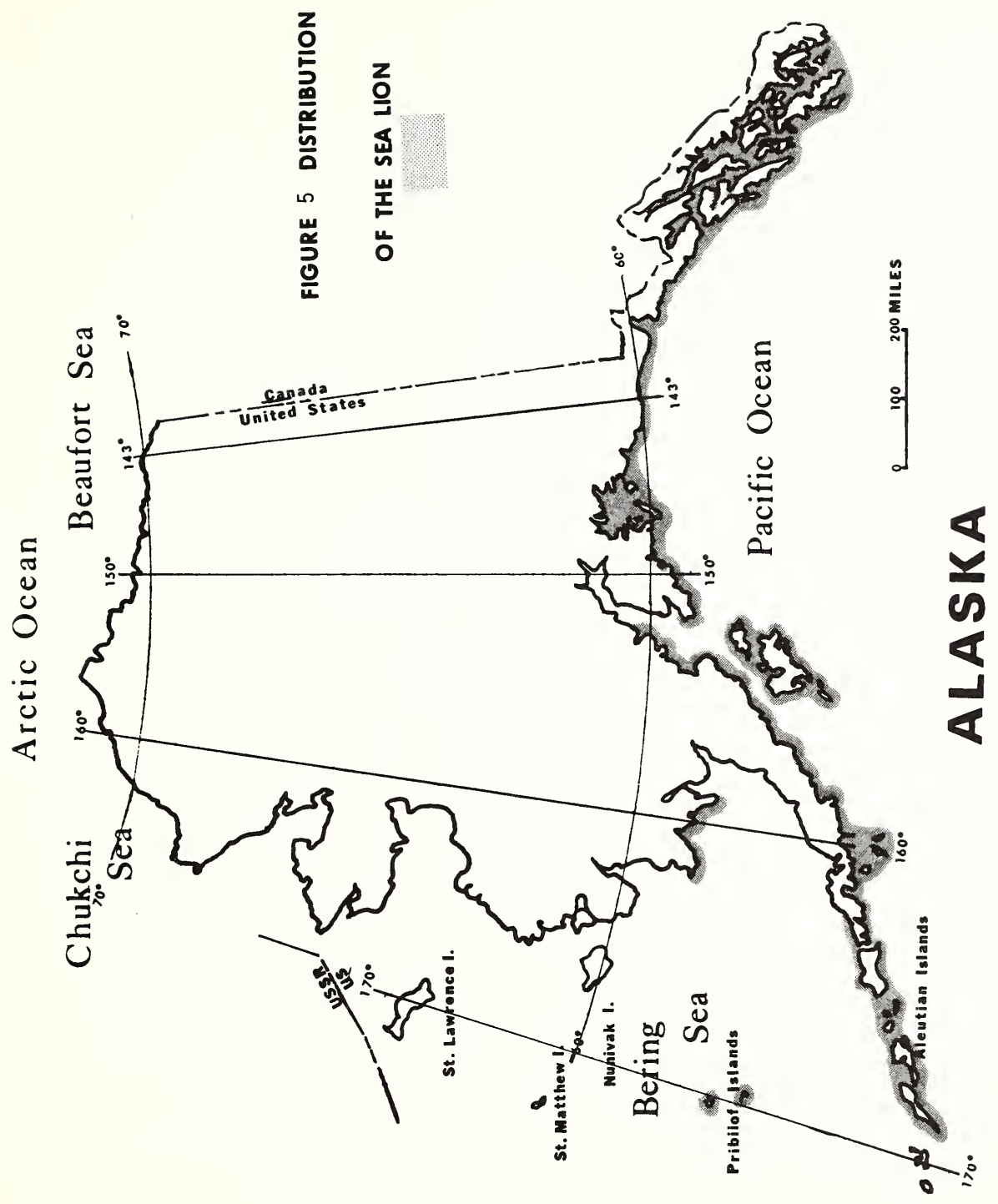


It should be noted that the above estimates for 1973 indicate the highest number of sea lions observed at a location at the time of the census. They do not account for those at sea during the census period (ADF\&G, 1973a) and, therefore, must be considered to be minimum estimates of population numbers.

\section{Carrying Capacity}

The sea lion has an affinity for specific, well-defined locations used as breeding and pupping rookeries and hauling areas along the coasts of Alaska. The availability of suitable land areas for these purposes may be a significant factor in determining the carrying capacity of the habitat for sea lions in waters off Alaska. During the 1973 population surveys, all except five of the known rookery areas were being utilized, and some of the latter five may have been abandoned, owing to changes wrought by the 1964 earthquake (Calkins, Pitcher, and Schneider, 1975). Moreover, personal observations by ADF\&G personnel (Vania, Calkins, Pitcher) indicate that adult densities at key rookeries (Akutan, Ugamak, Marmot Island, Sugarloaf Island) have not changed since the late 1950's, suggesting that, in these areas at least, the suitable breeding habitat For sea lions has been fully utflized for some time.

\section{Productivity}

Natality in sea lions is estimated to be 31 percent of the total population (ADF\&G, 1975). This annual rate is calculated using the premises that 65 percent of the total population is mature, 65 percent of mature sea lions are female, and 75 percent of adult females give birth yearly (approximately 66,000 pups). 
Food Habits

Sea lions are known to eat a wide variety of fishes, including lamprey, salmon, smelt, sand lance, rock fish, greenling, sculpins, halibut, and black cod. Invertebrates, such as shrimp, clams, squid, and octopus, also make up a part of the sea lions' diet (Fiscus and Baines, 1966; Mathisen and others, 1962). The kinds of food change with the season and the location of the sea lions. Many sea lions leave the breeding and pupping rookeries in favor of more protected waters during the winter and follow predictable feeding patterns, such as concentrating on herring spawning schools in the spring (Vania, written communication to L. Croxton, May 1975).

\section{Optimum Sustainable Population}

The northern sea lion population exhibits several characteristics which suggest that it is at or near the carrying capacity of its habitat. Wintering on sea ice is not typical behavior and suggests that the species is spilling over into less suitable areas of its habitat. At least in major rookeries, sea lions are apparently fully utilizing the available breeding habitat, and adult densities have remained stable for several decades.

Additionally, on the basis of observations of ADF\&G personnel (Vania, J.S. written communication to J. Blum, December 1973), juvenile mortality has increased in the sea 11on population. More than half the new pups die in their first year. Drowning, abandonment, malnutrition, and predation are major causes of death ( $A D F \& G, 1973 b)$. Mortality in yearlings and subadults has not been precisely measured but is also thought to be high (ADF\&G, 1975). This is verified by contrasting counts of yearlings on key rookeries (Akutan, Ugamak, Sugarloaf Island, Marmot Island) from the 1960's with those made recently--1973 and 1975: fewer juveniles were seen in the 1970 's than in the 1960 's. 
Finally, no significant exploitation of the population has occurred in any area for the past 40 years (ADF\&G, 1973a). Recent harvests (appendix D, p. 33) also appear to be insignificant (3 percent of the total population or less), particularly if one accounts for the fact that available population estimate is a minimum.

Thus, these lines of evidence suggest that in all areas the sea 1 ion population is currently at or very near its pre-exploitation level, which would be considerably in excess of the lower level of the range of OSP. Pacific Walrus (Odobenus rosmarus)

\section{Distribution}

The entire population winters in the seasonal ice pack of the Bering Sea, mainly south of lat. $64^{\circ} \mathrm{N}$, the greatest concentration (mostly females and young) belng 10 to 150 miles southwest of St. Lawrence Island. With recession of the ice in April-June, the majority moves northward to summer in the Chukchi Sea, mostly west of the International Date Line. About $8,000-10,000$ males remain behind in the Bering Sea, hauling out on islands in the Gulf of Anadyr and in Bristol Bay throughout the summer. Southward movement of the main population segment from the Chukchi to the Bering Sea takes place in October-Dec@mber, with large numbers hauling out on the Russian coast and at Ratmanov (Big Diomede), the Punuk Islands, and Amak Island (ADF\&G, 1973a). Distribution of walrus in Alaskan waters is shown in figure 6.

\section{$\underline{\text { Population }}$}

Before large-scale exploitation, which began about 1868 (Allen, 1880 , p. 185), the Pacific walrus was estimated to number 


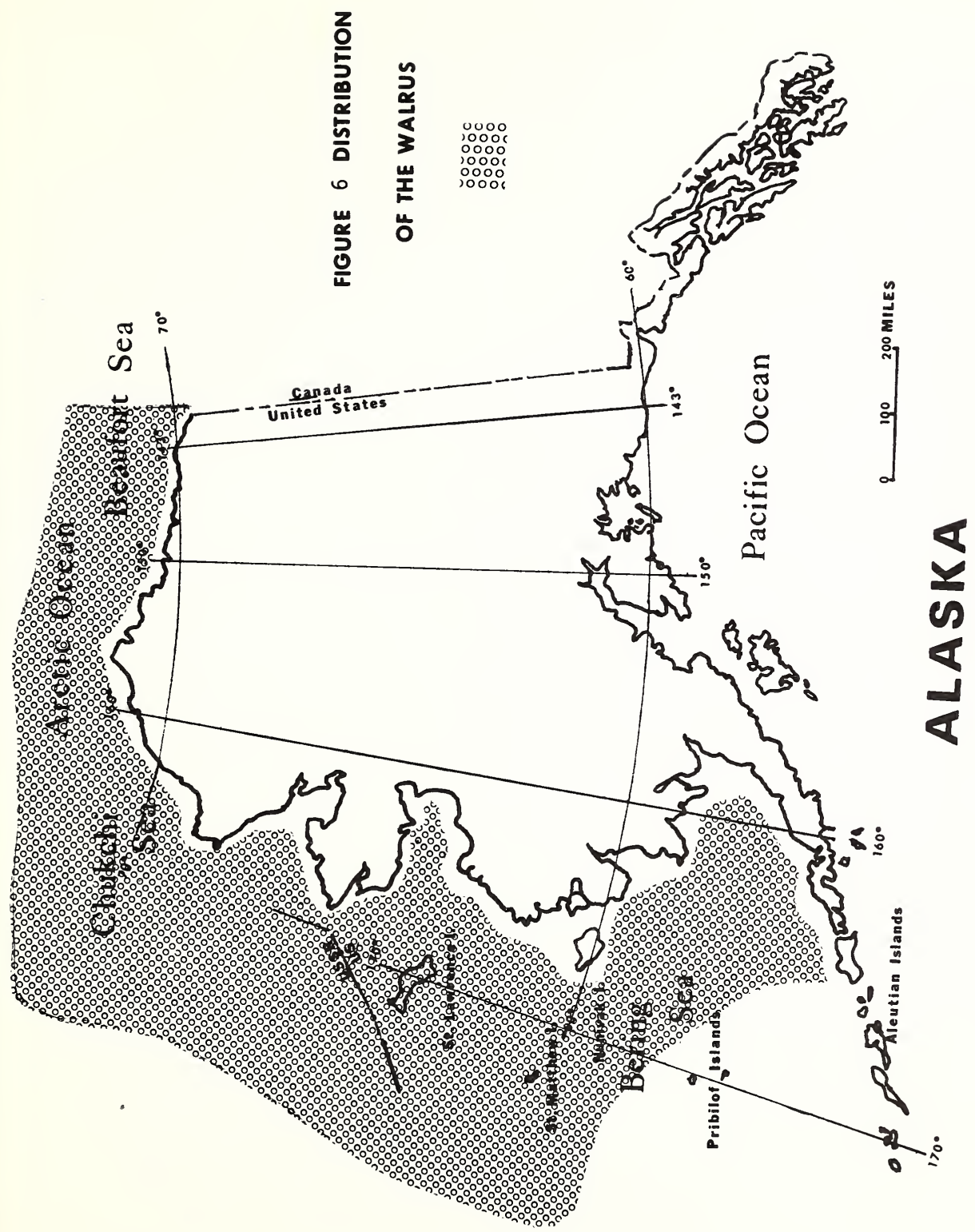


about 200,000 animals (Fay, 1957). Fay estimated that the population may have fallen to a low of 40,000 to 50,000 animals during the period 1950-65. Beginning in 1960, aerial surveys of walruses were undertaken. From data obtained on the five surveys--two in 1960, one each in 1961, 1968, and 1972--total estimates were computed by projecting the number of animals observed in 1-mile flight tracks to the estimated area occupied by walruses. From the 1960 surveys, the total population was estimated to range from 73,000 to 117,000 (Kenyon, 1960). The 1972 surveys provided a median estimate of 135,000 walruses and a range from 93,000 to 178,000 (Kenyon, 1972). J. J. Burns has gathered much basic biological information from walrus taken by Eskimos. From this, his estimate of the walrus population approximates the computed mean of the 1972 aerial survey (Burns, cited in R. A. Rausch, written communication, December 4, 1973). He maintained that the similar results obtained by the very different methods confirmed a population of approximately 140,000 walruses in 1972 and 1973 (a range of 85,000 to 162,000 ). This material, in comparison to the 1960 and 1972 surveys, indicates that the population is still increasing. Burns recently stated (testimony, 1975)* that he considers the 1975 population to be approximately 160,000 to 170,000. Also in 1975, Fay concluded that on the basis of rate of increase the current population could be 175,000 to 195,000 animals (testimony, 1975), whereas Johnson estimated a range between 150,000 and 200,000 animals (testimony, 1975). Burns' estimate of 170,000 will be used as the present population level.

\footnotetext{
*At a hearing on a separate, earlier proceeding to waive the moratorium only for the Pacific walrus, conducted in Anchorage, Alaska, by Administrative Law Judge Joseph B. Kennedy on March 18-22, 1975 (Docket No. Wash 75-1). Other references relating to the walrus in this document and citing "testimony, 1975" were also presented at this hearing.
} 
Fay also testified (testimony, 1975) that the Bering-Chukchi Sea walrus population is a single population stock. He also concluded that a historical level estimated at 200,000 animals probably constitutes a population maximum.

\section{Carrying Capacity}

The present population is exhibiting several characteristics which indicate that the population is at or near the carrying capacity of its habitat. It has reestablished itself in approximately the same geographic range previously inhabited, the birth rate is declining, pup mortality is high, and there is a large proportion of older adults in the population (Fay, testimony, 1975).

\section{$\underline{\text { Productivity }}$}

The Pacific walrus is one of the largest pinnipeds in the world, second in size only to the elephant seals. Males weigh up to $1,600 \mathrm{~kg}$ and females up to $1,000 \mathrm{~kg}$; calves at birth are about $60 \mathrm{~kg}$. Most females ovulate for the first time when 6 or 7 years old, and males become fertile 1 to 3 years later. Ovulation occurs biennially or less often and takes place mainly in FebruaryMarch. The animals are polygamous, with a midseason sex ratio of five cows to one bull in the main breeding area s@ithwest of St. Lawrence Island. The gestation period, including a 3- to 3.5-month delay of implantation, is about 15 months. Birth is mostly in May, during spring migration northward. Each female bears a single calf and nurses it usually for about 2 years. Females and young are highly gregarious; males are gregarious outside the breeding season. Hundreds may haul out together on a single ice floe or a smal1 island. 
Burns (testimony, 1975) noted calf per cow ratios among harvested animals of $1: 1$ in $1958-66,92: 100$ in $62-66,84: 100$ in $1967-70$, and 70:10 in 1971 through 1973. In 1974 it had dropped to 39:100. Burns stated that this indicated a decrease in productivity and is further evidence that the population is above maximum productivity level.

Fay (testimony, 1975) assumed that the population growth rate indicated by the 1960-72 census estimates averages about 7 percent per year. He also estimated a decline in net productivity: 6.9 percent in $1970,6.0$ in 1971, 5.6 in 1972, 5.2 in 1973, and 4.6 in 1974. Natality (births) in those years declined from 14.4 to 11.9 percent.

\section{Food Habits}

Fay (testimony, 1975) stated that walruses feed principally on benthic invertebrates and occasionally eat fishes or other marine mammals. Some 65 different species of marine organisms, representing 10 phyla, have been identified from the stomach contents and feces. Nearly all of these reside on or in the surface sediments and are probably obtained simply by grazing; those residing deeper in the sediments are apparently "rooted out," pig-fashion, by means of the snout. More than 3,000 of these organisms may be taken in a single meal by 1 walrus. The quality of the diet probably varies seasonally, geographically, and in relation to sex and age of the walrus. Nearly all of the data is from spring and summer in the Bering Strait and the 
Chukchi Sea; very little is known of the diet in autumn and winter in the Bering Sea. Walruses reared in captivity apparently consume about 5 percent of their body weight per day. At this rate, Fay (1957) calculated that a 1-ton walrus will eat about 18 tons of benthos per year; the entire population, at least 1.5 to 2 million tons per year.

Information available to Fay suggests that mollusks, especially snails and clams, make up the greatest part of the spring-summer diet, though other items such as tunicates and crustaceans may be of equal or greater importance in winter. In times of shortage of such foods, fishes and seals may be eaten. The walrus competes most with the bearded seal (Erignathus barbatus), whose diet seems to be similar in the spring-summer period, Walruses also eat some of the same kinds of organisms taken by the harbor seal, Phoca vitulina (e.g. pandalid shrimps) and by the gray whale, Eschrichtius robustus (e.g. gammarids, sma11 mollusks).

\section{Optimum Sustainable Population}

Fay (testimony, 1975) placed the unexploited population level of walrus at 200,000 animals. He further estimated that maximum productivity occurred in the mid 1960 's.

An examination of Fay's population model shows that walrus attained maximum birth rate in 1964 , when the population numbered 86,783 animals. The biological characteristics described under "carrying capacity" and "productivity" are indicators that the population stock is at a high level and is, therefore, above the level defined for the range of OSP. 
The above information on walrus populations was drawn from data in the environmental assessment prepared in 1975 in connection with the proceeding entitled "In Re: Waiver of moratorium on walrus..., Docket No. MMPA WASH 75-1." The evidence that was introduced in the 1976 hearing on the present action to waive the moratorium for nine species indicates that the waiver for walrus and return of its management to the State remains consistent with the mandates of the Act. The ALJ, therefore, recommended (1977, p. 92) that the waiver for walrus be continued.

\section{Harbor Seal (Phoca vitulina richardii)}

\section{Distribution}

Land-breeding harbor seals occur along the entire coastline of Alaska from Dixon Entrance to Kuskokwim Bay, including all of the Aleutian Islands and the Pribilof Islands. They are sympatric with the ice-breeding spotted seal in a broad area from Bristol Bay to Kuskokwim Bay and in the vicinity of the Pribilof Islands. These seals are common in the nearshore marine environment, frequently ascending rivers during the spawning runs of anadromous fishes. They frequently concentrate in the numerous glacial fiords of southeast Alaska, on the isolated islands in the northern Gulf of Alaska, along the Alaska Peninsula, and on many islands of the Aleutian Chain. Low densities occur in upper Cook Inlet, probably because of poor habitat in this area (Burns, 1973).

Harbor seals are abundant on the south side of the Kenai Peninsula around to Kachemak Bay. Large concentrations occur in Whidbey Bay, Aialik Bay, Harris Bay, and Nuka Bay. They are also abundant 


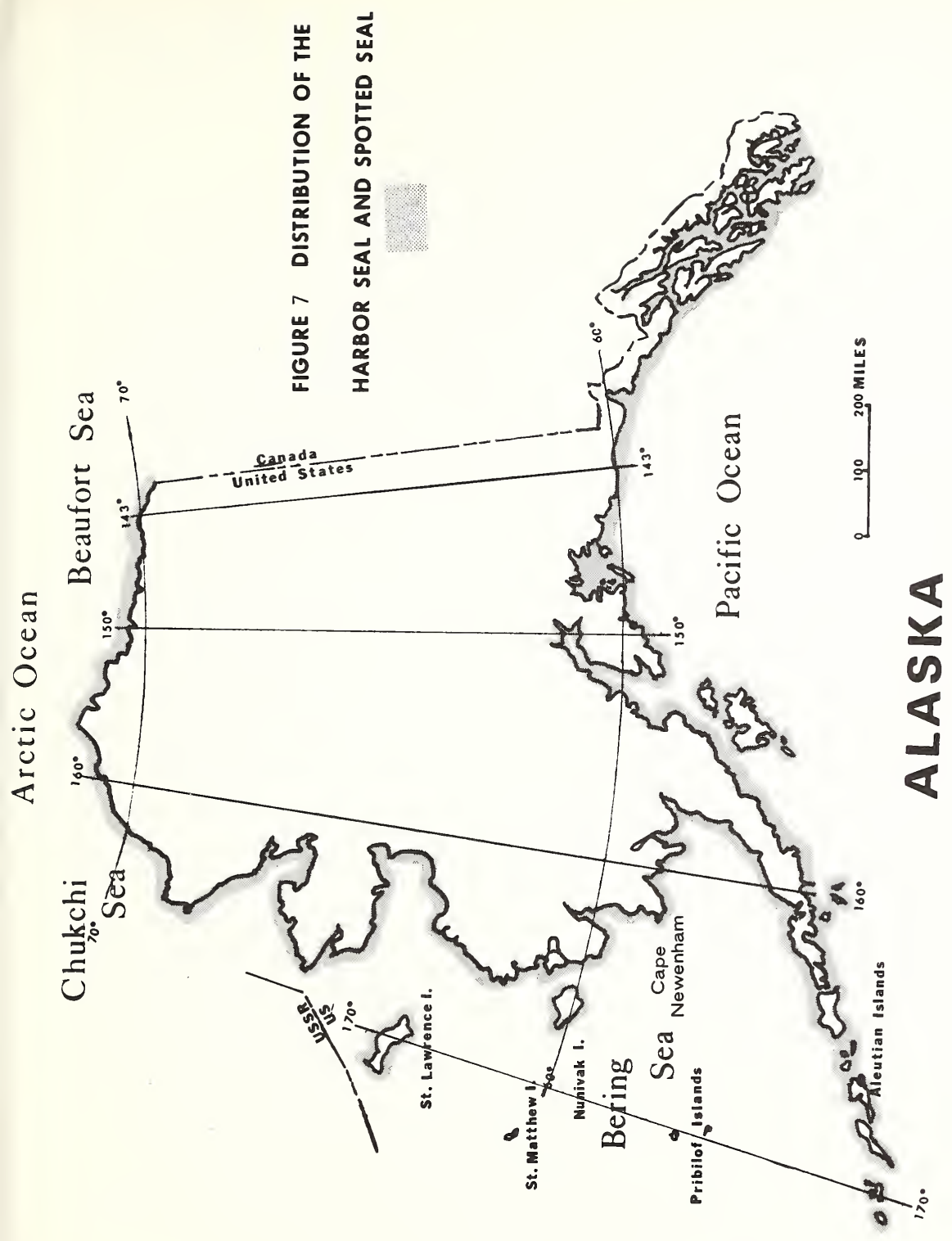


throughout most of the Kodiak Island-Afognak Island complex. Major

concentrations occur at Tugidak Island off the southern tip of Kodiak and Alitak Bay, on Ugak Island, and around Afognak Island (ADF\&G, 1973a).

The Alaska Peninsula and adjacent islands and the Aleutian Islands extend over 1,000 miles from east to west, contain thousands of square miles of good seal habitat, and support large populations.

Major concentrations occur on the north side of the Alaskan Peninsula, the two most important of which are the Port Heiden and Port Moller areas $(\mathrm{ADF} \& \mathrm{G}, 1973 \mathrm{a})$.

Seals occur in scattered high-density clusters from the south shore of Bristol Bay, through Kvichak Bay, Nushagak Bay, and along the Pacific shore of Nushagak Peninsula, in Kulukak Bay and Togiak Bay, around the Walrus Islands and Hagemeister Island, and skipping to the south shore of Kuskokwim Bay (ADF\&G, 1973a). Distribution of harbor seals is shown in figure 7 .

\section{Populations}

Overall, the world population of harbor seals appear to be large and stable, except in areas of dense human populations and development. About 525,000 are present in the North Pacific area and about 150,000 in the European North Atlantic region (Burns, 1973). There are two subspecies in waters off Alaska: the harbor seal (Phoca vitulina richardii) and the largha seal (‥ ‥ largha). The latter will be discussed separately.

Although the entire land-breeding harbor seal population in Alaskan-waters probably has a single gene pool, evidence to decide whether this is a single stock or several distinct stocks is not conclusive. 
Evidence presented at the hearing (ALJ, 1977) tended to support the belief that there is but one population stock of the land-breeding harbor seal. A blood protein analysis on various isolated harbor seal groups indicate that they are a common genetic population (Pitcher, testimony, 1976). The harbor seal may migrate and interbreed over a wide area and may be capable of repopulating localized areas of intense exploitation such as occurred in the mid-1960's.

The secretive nature of these animals and the broad expanse of habitat in which they are found makes direct population estimates difficult. However, from past harvest records and aerial surveys in selected areas, particularly Kodiak Island and the north side of the Alaska Peninsula, ADF\&G estimated that the total population numbers 270,000 seals, distributed as follows: $(A D F \& G, 1973 a):$

\begin{tabular}{|c|c|c|}
\hline $\begin{array}{l}\text { Area } \\
\text { number }\end{array}$ & Geographic description & $\begin{array}{l}\text { Approximate } \\
\text { abundance }\end{array}$ \\
\hline 1 & $\begin{array}{l}\text { Dixon Entrance to Cape Fairweather } \\
\text { (southeastern Alaska) (GMU 1-4)* }\end{array}$ & 30,000 \\
\hline 2 & $\begin{array}{l}\text { Cape Fairweather to Prince William } \\
\text { Sound and Kenai Peninsula (GMU 5-7) }\end{array}$ & 70,000 \\
\hline 3 & $\begin{array}{l}\text { Cook Inlet, Kodiak Archipelage, } \\
\text { Shelikof Strait, and south side of } \\
\text { Alaska Peninsula (GMU } 8,9(\mathrm{~s}), 15,16)\end{array}$ & 55,000 \\
\hline 4 & Aleutian Islands (GMU 10) & 85,000 \\
\hline \multirow[t]{2}{*}{5} & $\begin{array}{l}\text { North side of Alaska Peninsula, } \\
\text { Bristol Bay, and Pribilofs } \\
\text { (GMU } 9(\mathrm{n}), 17)\end{array}$ & 30,000 \\
\hline & Total & 270,000 \\
\hline
\end{tabular}


Productivity

Sexual maturity is attained by female harbor seals at 3 to 5 years and by males at 5 to 6 (Bigg, 1969, and Bishop, 1967). They are relatively long lived, some living more than 30 years. Pupping occurs from late May to mid-July, the majority taking place during the first 3 weeks in June.

Females ovulate and breed 3 to 4 weeks after giving birth to the pup. Delayed implantation occurs, and embryonic development is retarded for about 2 months. The period of active fetal development is about 9 months. No significant amount of twinning is known to occur (ADF\&G, 1975).

Natality of the land-breeding harbor seal in Alaska is variable according to area, ranging from 21 percent to 35 percent. ADF\&G data indicate that in the Aleutian Islands natality is lowest at about 21 percent; in the areas of Prince William Sound and Kodiak Island, it may be as high as 35 percent (Vania, J. S., written communication to L. Croxton, May 1975). The net productivity is unknown but probably is low in some areas since certain populations are thought to be at or near the carrying capacity of their habitat $(A D F \& G, 1975)$.

\section{Food Habits}

Harbor seals are mainly fish eaters and are usually found near shore in water less than 30 fathoms deep. They feed on a wide variety of species including herring, gadids, flounders, smelt, rockfish, sculpins, salmon, and greenling. Octopus, squid, and shrimp have also been found in large quantities in harbor seal stomachs (Spalding, 1964). 
Optimum Sustainable Population

Before 1963, only small harvests $(6,000-10,000$ per year) were taken from the population for subsistence and bounties. Owing to favorable prices for pelts on the world market during the mid-1960's, harvests then increased, peaking at 50,000 seals in 1965 . This short period of intensive exploitation was localized, however, to only a few accessible areas in southeastern Alaska, Prince William Sound, and the Kodiak Archipelago. Harvests later declined as prices fell, reaching a low level of 9,000-11,000 in 1970-72 (Pitcher, testimony, 1976). On the basis of field observations, ADF\&G estimates that the annual incidental. take from the population has probably been under 1,000 seals since 1972 (Pitcher, testimony, 1976). Owing to its localized nature, the above exploitation history probably had little direct effect upon most of the harbor seal population; e.g., a commercial harvest did not occur in the Aleutian Islands, which currently support over 30 percent of the population (ADF\&G, 1973a). Although the effect of harvests must have been substantial in some localities of southeastern Alaska, Prince William Sound, and the Kodiak Archipelago, adjacent unexploited areas may have served to repopulate them, as happened in the Copper River after a predator control program, designed to reduce fisherman-harbor seal conflicts, ceased in 1962.

Although harvests in these three areas declined substantially after 1967 , little evidence is available to indicate the degree of recovery, if any, in these three stocks in subsequent years. Personal field observations by ADF\&G personne1 (Pitcher, Vania, Burns) suggests that harbor seals in these areas are more numerous now than in the late 1960's and, as a whole, are 
well above the point of maximum productivity (Pitcher, testimony, 1976). Pitcher (testimony, 1976) believes two areas, Kodiak Island and the Kenai Peninsula, remain areas of concern.

In an unpublished $A D F \& G$ analysis (Burns, J.J., written communication to J. Blum, December 1973), circumstantial evidence suggests that the age of sexual maturity in southeastern Alaska, Prince William Sound, and the Kodiak Archipelago is 1 to 2 years later than that found in the heavily exploited population of Vancouver Island (Bigg, 1969), and that levels of abundance in Glacier Bay at first increased and then remained stable following the cessation of hunting in 1972 .

A stable level of abundance and an increased age at sexual maturity, as suggested above, indicate that the recovery process in these areas is slowing down. This would be the case if a population were increasirg beyond its level of maximum productivity. Given this implication and accounting for the localized nature of exploitation in the mid-1960's, the ADF\&G believes that the harbor seal population is probably above the lower level of the range of OSP.

In area 4 (Aleutian Islands), harbor seals were mainly hunted for subsistence purposes, and harvests thus were never significant (ADF\&G, 1973a). Moreover, compared to those in other areas, this stock still contains a rather large proportion of large, old seals, which is indicative of its having been at or near its carrying capacity for some time (ADF\&G, 1975). Thus, the stock in area 4 is likely at its pre-exploitation level, which is considerably above the lower level of the range of OSP. 
In the area north of the peninsula (area 5), the stock's response to removals of 2,500-4,500 seals since 1965 has been monitored closely through extensive aerial surveys. Apparently, these harvests have been sustained by the stock with no measurable change in numbers (ADF\&G, 1973a), and it remains at or near its pre-exploitation (pre-1965) level, which should be well above the lower level of the range of OSP.

Ice-Breeding Spotted Seal (Phoca vitulina largha), or Largha Seal

\section{Distribution}

Both ice-breeding and land-breeding populations of harbor or spotted seals occur in the Bering Sea. The land-breeding seals occur primarily along the north coast of the Alaska Peninsula and Aleutian Islands, whereas the ice-breeding form occupies a wide range, depending upon season, throughout the northern Bering and Chukchi Seas.

The two types of harbor seals can be easily identified on the basis of morphological differences. Largha seals are seasonally dependent upon sea ice for the birth and nurture of their pups. During winter and early spring, the entire population is concentrated along the southern edge of the seasonal pack ice, usually in the central Bering Sea. These seals move northward and toward the coasts as the seasonal retreat and disintegration of sea ice progresses. During the ice-free summer and early fall, they occur along the entire coast of northern Alaska. The largha seal is the dominant near-shore seal during ice-free seasons of the year and is replaced by the ringed seal when ice is present (ADF\&G, 1973a).

Distribution of the largha seal is shown on the map (figure 7) as a northern extension of the range of harbor seal, the dividing point occurring essentially at Cape Newenham, the southern end of Kuskokwim Bay. 


\section{Population}

Two population stocks of largha seals are recognized, only one of which mainly occurs in Alaskan waters. A Karaginskii Bay stock exists primarily in waters of the Soviet Union, and a Bering Sea stock occupies and breeds on the ice-front zone from Cape Olyutorskiy in the north to Bristol Bay in the south.

Three ship expeditions (1968, 1971, and 1972) in the Bering Sea revealed that during the pupping and breeding seasons, from late March to mid-April, adults and pups are evenly distributed throughout the ice-front zone in groups composed of an adult male, adult female, and her pup. These groups (triads) rarely occur closer than 0.25 kilometer to each other. Nonbreeding and subadult seals also occupy the same area but seldom haul out on the ice at this time of the year.

Indices of abundance (triads per square mile) have been formulated by Burns on the basis of these ship observations (1973, unpublished notes). These indices indicate that the popuiation apparently has remained stable during the years surveyed. Burns also estimated population size from an estimate of the number of triads in the ice-front zone (area of zone times index of abundance), given that two adults occur per triad and that adult (breeding) seals make up 64 percent of the total population. Utilizing the most conservative index of abundance and the minimum estimate of area in the ice-front zone gave a minimum population size of $200,000-250,000$ for the Bering and Chukchi Seas. The Soviets estimate the total (Bering, Chukchi, and Okhotsk Seas) largha population at 450,000 (ADF\&G, 1975). 
Spotted seals presently occur throughout all of their previously known range in western and northern Alaska. They commonly enter embayments and streams in conjunction with concentrations of spawning fishes (ADF\&G, 1975). Nothing is actually known of historical population levels of the largha seals. However, all indications are that present levels are probably not much different than during the $18 \mathrm{th}$ and 19 th centuries. On the basis of distribution, magnitude, and level of hunting effort, fewer seals are taken annually by Alaskan residents at the present time than during the last several hundred years.

\section{Productivity}

Adult seals pair up in March for the duration of the breeding season. A white-coated pup, about $84 \mathrm{~cm}$ long and weighing between 9.5 and $11.8 \mathrm{~kg}$ is born on the ice to each pair from late March to mid-April. The pup is suckled for about 4 weeks, in which time its weight is tripled. Males become sexually mature at 4 to 5 years of age; females, at 3 or 4 years. Breeding is annual, and the gestation period (including delayed implantation) is about 10.5 months. Maximum 1ongevity is at least 35 years. Although isolated in pairs during the breeding season, adults are gregarious at other times (ADF\&G, 1973a).

Natural mortality of largha seals during the first year of life is high and, based on indirect evidence, may approach 35 to 50 percent. The presence of weaned, starving pups on shore during the summer months is an annual occurrence (ADF\&G, 1975). 
These seals are primarily fisheaters during summer and fall and take advantage of spawning concentrations of salmon, herring, capelin, smelt, and whitefish, which occur along the coast and in the numerous bays and river mouths. In winter, when these seals are at sea among the ice floes, they continue to utilize fishes where they are available. They also feed on shrimp, small crabs, and cephalopods (ADF\&G, 1973b).

\section{Optimum Sustainable Population}

Harvests by both Americans and Soviets averaged 7,000 per year during the late 1960's and 1970's (ADF\&G, 1975; unpublished data exchanged by U.S.-U.S.S.R. Marine Mammal Subgroup). In earlier years, harvests of a similar magnitude were recorded (ADF\&G, 1973a). Such a take would appear to be insignificant, 3 percent or less of the stock, particularly if it is noted that the available estimate of stock size is a minimum. Moreover, as previously noted, indices from recent ship surveys have remained constant despite this slight harvesting pressure. Consequently, the largha population is likely at or only slightly less than its pre-exploitation level, which would be considerably above the lower level of the range of OSP.

\section{Ringed Seal (Pusa hispida)}

\section{Distribution}

The ringed seal generally has a wide range throughout the areas of seasonal ice cover in the Bering and Chukchi Seas and north into the permanent ice of the Polar Basin. In the Bering and Chukchi Seas and along the Arctic coast, the majority of ringed seals occupy those regions covered by extensive land-fast ice in winter. However, nonbreeding adults and juveniles 
may occur anywhere in the ice covered areas. The association of ringed seals with sea ice results in marked seasonal migrations of animals wintering in the Bering and Chukchi Seas and relatively little movement of those seals residing in more northerly areas. The ringed seal is the dominant near-shore seal during months when sea ice is present and is replaced by the spotted seal during ice-free months. A small portion of the population, mainly juveniles, may remain in ice-free areas during summer. Distribution of the ringed seal in Alaskan waters is shown in figure 8 .

\section{Population}

An aerial census in 1970 of ringed seals on land-fast ice along the northern coast of Alaska indicated a variation in numbers from 5.36 per square mile in the Chukchi Sea between Point Lay and Wainwright, to $\mathbb{1 . 0 6}$ per square mile in the Beaufort Sea between 0liktok and Flaxman Island (Burns and Harbo, 1972).

To estimate population size, Burns (1973, unpublished notes) chose conservative indices of abundance from each survey area and multiplied by the minimal estimate of the area of land-fast ice in each. Then, to account for unobserved seals under the ice, this figure was multiplied by a factor of two as suggested by Smith (1973). Finally, the Siberian component of the population was estimated to be equivalent to the Alaskan component, leading to a total estimate of 250,000 ringed seals in the land-fast ice of the Bering, Chukchi, and Beaufort Seas (ADF\&G, 1973a). Burns indicated that this should be considered a minimum estimate since recent ship and helicopter surveys 


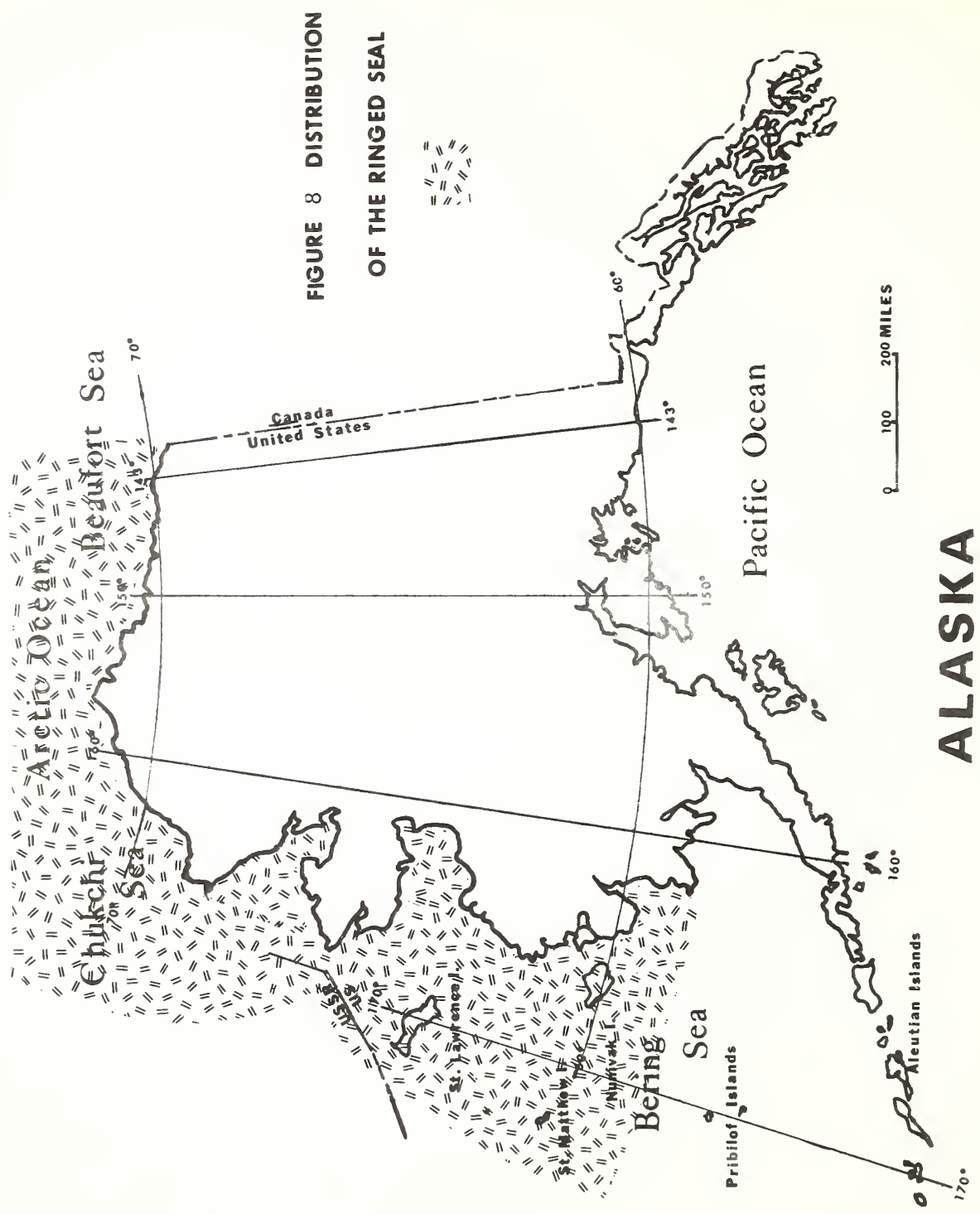


found a considerable number of ringed seals in the pack ice, as well as in land-fast ice of the Chukchi and Beaufort Seas. More recently, Burns, testimony, 1976) estimated a total population of 1 million to 1.5 million ringed seals in the Bering, Chukchi, and Beaufort Seas.

Soviet estimates of the population size are difficult to evaluate since they recognize three subspecies whose ranges overlap and none coincides with the Bering-Chukchi Seas population recognized by ADF\&G scientists. The Soviet recognized populations are:

$$
\begin{array}{lc}
\text { Arctic Ocean (includes Chukchi Sea) } & 5 \text { million-6 million } \\
\text { Western Bering Sea } & 12,000 \\
\text { Okhotsk Sea } & 800,000-1 \text { million }
\end{array}
$$

\section{Productivity}

Maximum longevity of ringed seals exceeds 25 years, and the species is probably monogamous. Males become sexually mature at 6 to 8 years of age; females, at 5 to 7 years. The ringed seal breeds annually and has a 10.5 month gestation period (including delayed implantation). The pups are born with white coats from March to early April in a birth lair within an ice pressure ridge or under drifted snow.

\section{Food Habits}

In relatively shallow areas, ringed seals feèd on many bottom-dwelling invertebrates such as shrimp, amphipods, and crabs. However, the major food items are fishes, including sculpins, Arctic cod, and saffron cod. During fall and winter months, fish usually make up more than 90 percent of a seal's diet. During spring, invertebrates are the major food items. Little is known about the summer feeding habits of ringed seals. 
Ringed seals also occur in areas of the Arctic Ocean where water depth is too great for bottom feeding. In these areas, they eat primarily invertebrates from the upper water layers, including euphausiids, amphipods, and larval forms of other groups. This type of feeding is accomplished by straining water through their extensively serrated teeth (ADF\&G, 1973b).

\section{Optimum Sustainable Population}

Since the late $1960^{\prime} \mathrm{s}$, the combined Soviet and American harvest has been 9,000-16,000 ringed seals per year (ADF\&G, 1975; unpublished data exchanged by U.S.-U.S.S.R. Marine Mammal Subgroup). Such a take, comprising 4-6 percent of the U.S. estimate of the land-fast population, would appear to have a small impact on the population size, particularly in view of the large Soviet estimates of population size. Even a take on the order of 20,000 per year, such as occurred during 1964-66 in response to favorable pelt prices, probably would not have affected this population severely. Therefore, although the ringed seal population may have been reduced below its pre-exploitation level slightly, it would still be very near the upper limit of the range of OSP.

\section{Ribbon Seal (Histriophoca fasciata)}

\section{Distribution}

Based on geographic considerations, ribbon seals are separable into two groups, the Okhotsk and the Bering-Chukchi populations. Nothing is known about exchange between these groups. However, based on the lack of physical barriers and the apparent continuity of suitable habitat, it is probable that exchange does occur. In the latter group, the center of abundance is the central Bering Sea. Ribbon seals are seasonally dependent upon the seaice platform for the birth and nursing of their pups. During winter and 
early spring, the entire population is concentrated along the southern edge of the seasonal ice. Concentrations of ribbon seals can be located in the ice-front zone from March through early June. In most years, by the time the ice edge recedes north through the Bering Strait, there are only a small number of ribbon seals associated with the ice. All evidence to date indicates that ribbon seals are pelagic, mainly in the Bering Sea, during ice-free seasons. Distribution of the ribbon seal in Alaskan waters is shown in figure 9 .

\section{Population}

Ship surveys conducted in the Bering Sea in 1968, 1970, and 1971 provided indices of abundance (pups per square mile) for ribbon seals occurring along the front ice. To estimate population size, Burns (1973, unpublished notes) first estimated pup abundance by multiplying a conservative index value times the minimum estimate of area within the zone of front ice. By assuming that the number of pups and females were equivalent and that the ratio of males to females was unity, the estimated pup abundance was expanded to include the number of adults (ages 4 and older). Accounting for the 20 percent of the population which is immature (ages 1-3) then gave the estimated total population size of at least 100,000 ribbon seals in the Bering-Chukchi Seas.

Soviet estimates for the same population indicated $80,000-90,000$ ribbon seals in 1965, the midpoint of the perlod of heavy Soviet exploitation of this species (ADF\&G, 1975). Comparing the two estimates would seem to indicate that recovery of the population has occurred following Soviet implementation in 1968 of major reductions in their commercial harvest. 


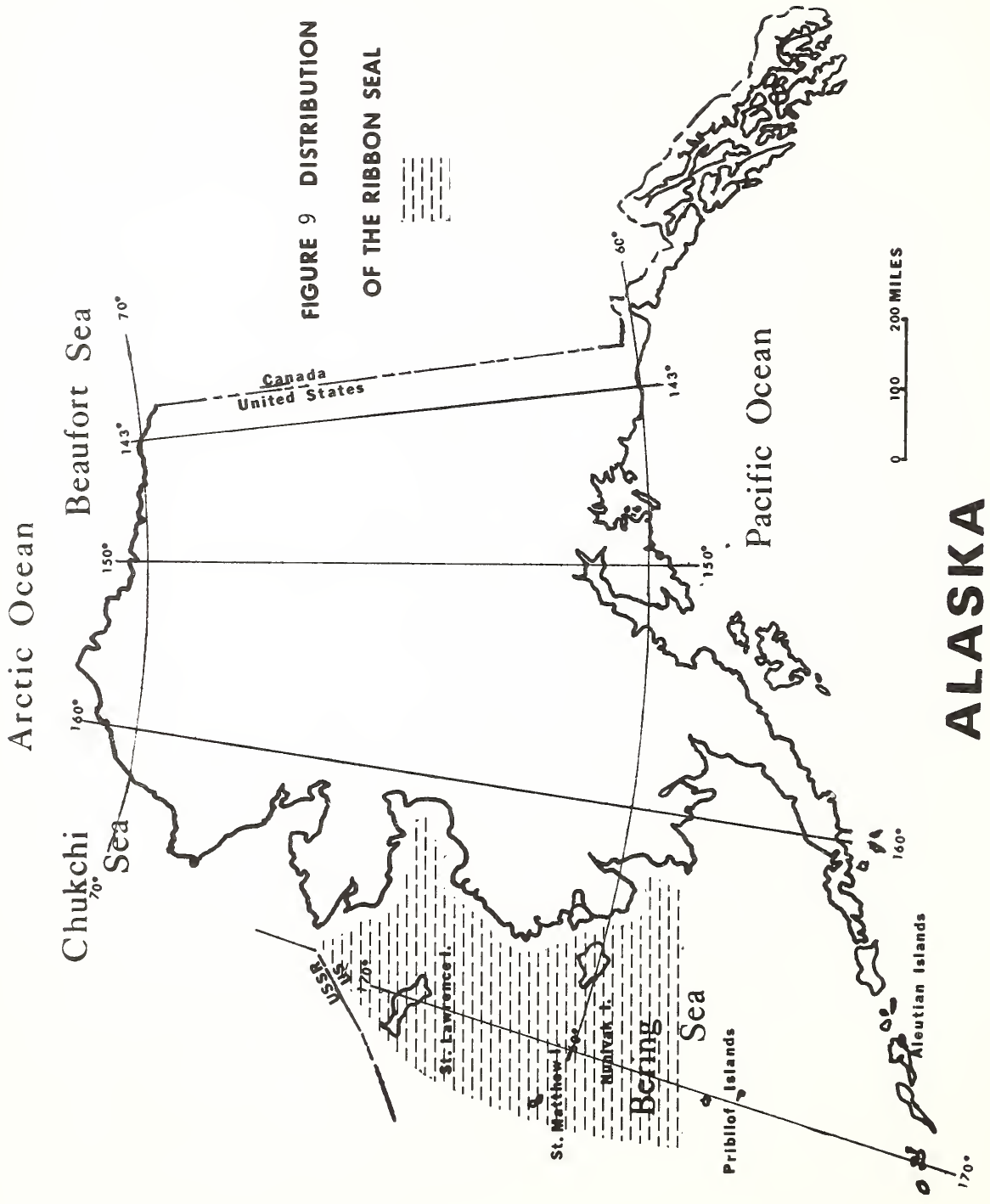




\section{Productivity}

Pups are born with white coats during March to mid-April. Nursing lasts about 4 weeks, in which time their weight is tripled. Males become sexually mature between 3 and 5 years of age; females, between 2 and 4 . Breeding is annual, and the gestation period (including delayed implantation) is probably around 10.5 months. Maximum longevity is 22 to 26 years (ADF\&G, 1973a).

\section{$\underline{\text { Food Habits }}$}

The diet of these seals during the late winter and early spring (in the iceedge zone) is similar to that of the spotted seal, including primarily pelagic and demersal fishes, cephalopods, and sma11 crustaceans (ADF\&G, 1973a). Optimum Sustainable Population

The American harvest of ribbon seals has been insignificant (ADF\&G, 1973a). During 1962-67, the Soviet harvest was considerable, averaging 13,000 per year (unpublished data exchanged by U.S.-U.S.S.R. Marine Mammal Subgroup). This harvest noticeably reduced the population below its pre-exploitation level (ADF\&G, 1973a) .

Some evidence suggests, however, that the population may have recovered following stringent reductions of the Soviet harvest in 1968. A comparison of Soviet counts obtained from vessel surveys of the Bering Sea front ice indicates an apparent 20 percent increase in population size between 1972 and 1974 (ADF\&G, 1975). Since 1968, an increase in the population size should have occurred despite a continuing Soviet harvest of about 3,000 seals per year (unpublished data exchanged by U.S.-U.S.S.R. Marine Mammal Subgroup), which would constitute about 3 percent of the current population estimate. 
Evidence now indicates that the ribbon seal stock has recovered to 75 percent of the Soviet estimate of pre-exploitation size of 100,000 to 114,000 animals (Burns, testimony, 1976). Finally, field observations of the relative densities of ice seals during early phases of exploitation suggest that the number of ribbon seals in the eastern Bering Sea has always been low, even at the population's pre-exploitation level (Burns, testimony, 1976). Consequently, the weight of evidence is that although the ribbon seal population was heavily exploited, it has since recovered to a level above the lower level defined for the range of osp.

\section{Pacific Bearded Sea1 (Erignathus barbatus)}

\section{Distribution}

The bearded seal is found in the North Pacific region in the Bering, Okhotsk, and northern Japan Sea and is circumpolar in the Arctic Ocean. In winter and spring, it is found from the southern edge of the seasonal ice pack north to permanent ice, wherever areas of broken, moving ice exist. During summer and autumn, it occurs along the edge of the permanent polar ice of the Arctic Ocean. Marked seasonal migrations are associated with the advance and retreat of the seasonal ice. The bearded seal is usually solitary, although very loose aggregations are sometimes observed during the breeding season. It does not normally come ashore (NMFS, 1974). In the waters off Alaska, it occurs throughout the wide area of seasonal ice cover in the Bering, Chukchi, and Beaufort Seas (Burns, 1973). Distribution of the bearded seal in Alaskan waters is shown in figure 10. 


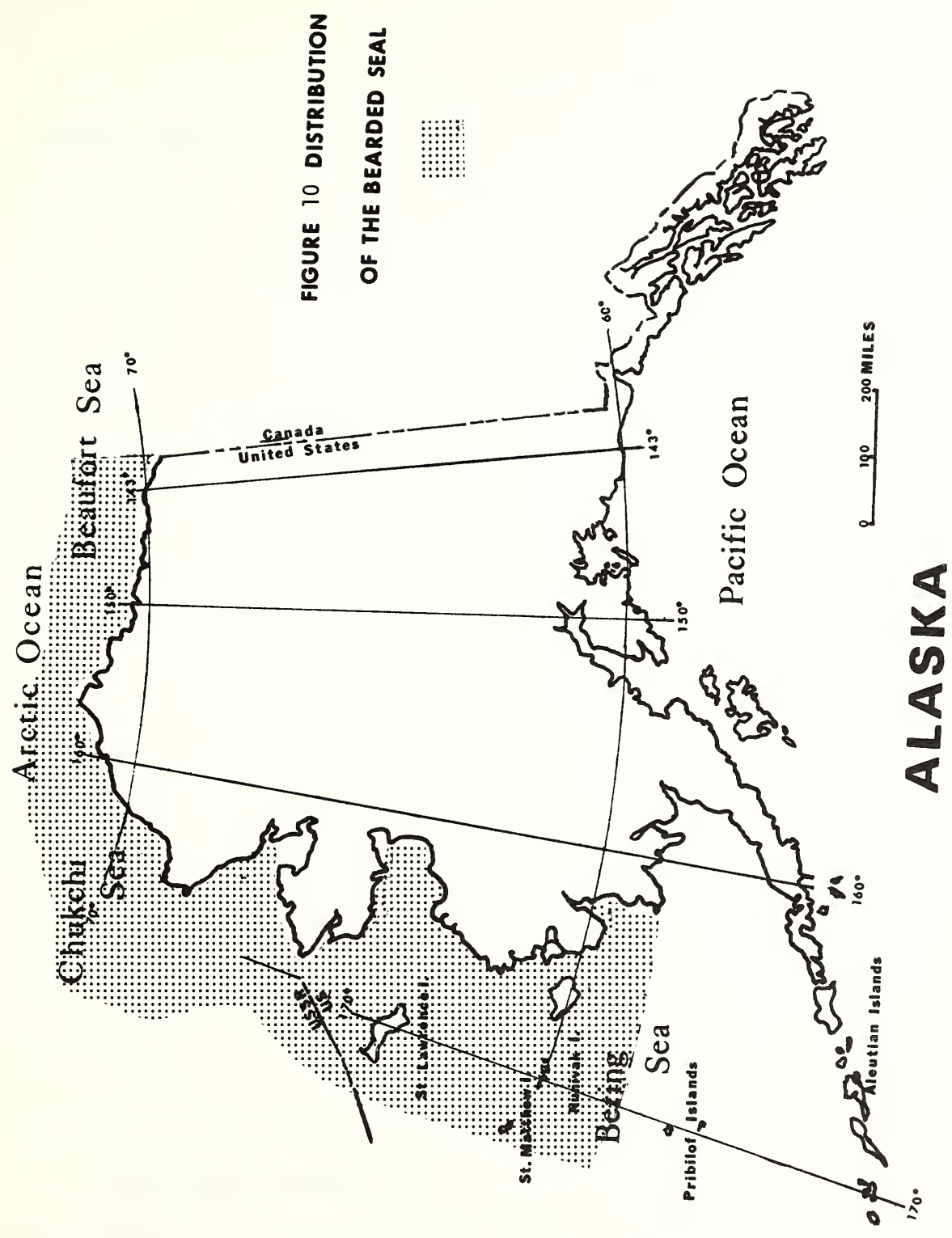




\section{Population}

Based upon sh1pboard surveys conducted in the Bering Sea in 1968, 1971, and 1972, Burns (1973, unpublished data) formulated indices of abundance (numbers per square mile) for this widely distributed inhabitant of the drift ice. These indices indicate that, at least in the Bering Sea, the population has remained stable during the survey period. Burns also estimated population size by multiplying conservative indices of abundance times the minimum estimates of the area of drift ice in the Bering and Chukchi Seas. This procedure ylelded a mintmum size of 300,000 for the Bering and Chukch1 Seas, the population which migrates seasonally into the east Siberian and Beaufort Seas (NMFS, 1974). The Soviets estimated the population level of Pacific bearded seals (those occurring in the east Siberian, Chukchi, Bering, Okhotsk, and Japan Seas) to be 450,000 (ADF\&G, 1973a).

\section{Productivity}

The female bears a single pup, usually during late April or early May, which weighs about $31 \mathrm{~kg}$ and is $132 \mathrm{~cm}$ long. The pup's weight is tripled within 12 to 18 days. Most adult females breed within 2 weeks of weaning their pup. The period of pregnancy is 10.5 months, including 2.5 months of delayed implantation. Some females ovulate at an age of 3 years, but reproductive maturity is not attained until they are 5 or 6 years old. The males become sexually mature at 6 or 7 years of age (Burns, 1973).

\section{Food Habits}

The bearded seal consumes several species of invertebrates, principally crabs, shrimp, clams, and amphipods, in addition to some demersal fishes. They utillze some specles presently harvested by man. Most notable of these 
are the pandalid and crangonid shrimps and lithodid crabs. These seals do not directly compete for commercially important fish species and pose no threat from the standpoint of damage to fishing gear (Burns, 1973).

\section{Optimum Sustainable Population}

The combined American and Soviet harvest of this species ranged as high as $8,000-10,000$ per year during the mid-1960's but during the $1970^{\prime}$ s declined to 3,000 per year (ADF\&G, 1975; unpublished data exchanged by U.S.-U.S.S.R. Marine Mammal Subgroup), of which native hunters take 1,500-2,000. Moreover, harvests prior to the $1960^{\prime}$ s were of the same low order of magnitude (ADF\&G, 1973a). Such a take would not seem to be significant, being in the range of 3 percent or less of the current minimum population estimates; as also noted, indices from recent ship surveys have remained stable despite this low level of exploitation. Consequently, the bearded seal population is probably at or only slightly below its pre-exploitation level, which would be considerably above the lower level of the range of OSP.

\section{Beluga (Delphinapterus leucas) or Belukha}

\section{Distribution}

The beluga whale inhabits the Arctic Ocean and adjacent seas, including the Okhotsk and Bering Seas, Cook Inlet, Hudson Bay, and Gulf of St. Lawrence. Three subspecies are recognized: dorofeevi from the Okhotsk Sea; marisalbi in the Barents and White Seas; and leucas in the rest of the range (Rice and Scheffer, 1968). In the Pacific, beluga whales are common along the Alaska coast as far south as Bristol Bay, and an apparently 
separate population is found in Cook Inlet. Belugas are gregarious and travel in groups of two or three up to hundreds (ADF\&B, 1973a).

Belugas often ascend rivers. In shallower rivers, such as the Kvichak, their movements are strongly influenced by tides. They often travel as much as 30 to 40 miles upstream on very high tides. In deeper rivers, such as the Yukon, they may travel far upstream beyond the tidal influence. Belugas are occasionally sighted at Nulato, 450 miles upstream on the Yukon River. Distribution of the beluga in Alaskan waters is shown in figure 11.

\section{Population}

The world population of beluga whales is estimated to be between 32,000 and 58,000. In Alaska, they appear to be separated into two population stocks (NMFS, 1974).

The Cook Inlet population stock is considered a distinct and separate stock based on the low potential for genetic interchange (ALJ, 1977). Based on aerial surveys, the Cook Inlet population is estimated at 500 animals and is not expected to change significantly in the near future (ADF\&G, 1973a).

Belugas in Bristol Bay and the Bering and Beaufort Seas are considered to be one stock (ADF\&G, 1975). Brooks (1952) estimated that the Bristol Bay component comprises 1,500 animals, whereas Burns has determined from unpublished personal observations and miscellaneous aerial and vessel sighting reports that the Bering and Beaufort Seas component must comprise at least 8,000 individuals. Summing these components gives a total population of at least 9,500 . 


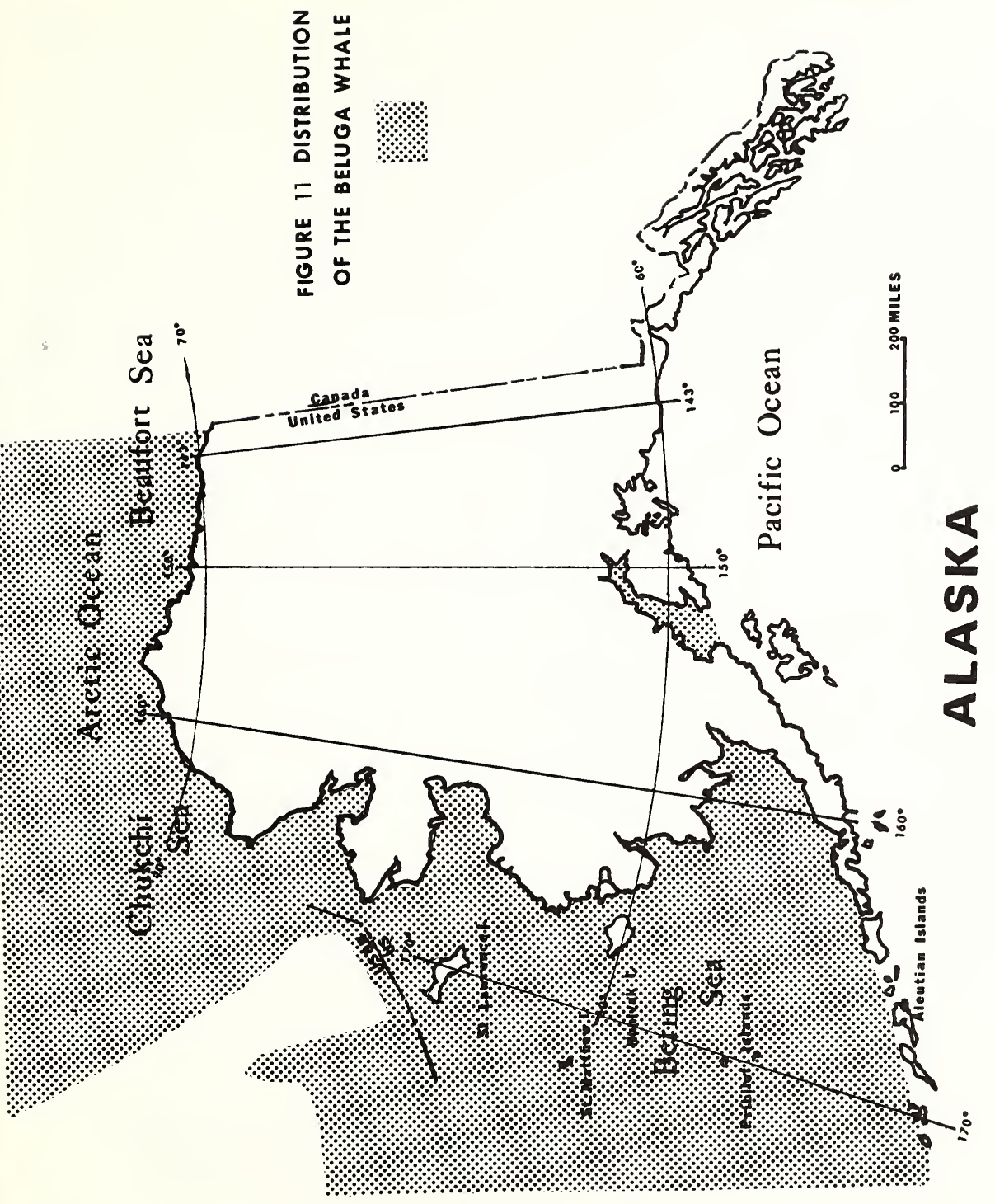




\section{Carrying Capacity}

Belugas in Alaska have never been subjected to heavy rates of exploitation. Traditionally they have been used as a source of meat, muktuk, and oil for both humans and dogs by the residents of villages on the Bering Sea and Arctic Ocean coasts and along rivers that belugas periodically ascend. The decreased use of the sled dog (as a result of the introduction of the snow machine), the availability of alternate commercial food sources through the development of a cash economy, and welfare measures such as food stamps, may have reduced the demand for beluga products in some villages--particularly in the southern portion of the beluga's range. Some native spokesmen, however, maintain that the need is increasing (see comments, Chapter IX, by D. Friday, Nunam Kitlutsisti). From Norton Sound north, belugas are still taken regularly in some communities (ADF\&G, 1973a).

The present estimated number of animals in the two population stocks are considered to be at the carrying capacity of those habitats (ADF\&G, 1973a).

\section{$\underline{\text { Productivity }}$}

Females reach sexual maturity at about 5 years of age and give birth every 2 or 3 years. Calves are born in the spring, the peak oalving occurring near mid-June. Gestation lasts 14 months and lactation about 20 months. Production has been estimated at 14.3 percent of the total herd per annum (Sergeant, 1973).

\section{Food Habits}

Belugas feed on both fishes and invertebrates. Fishes found in beluga stomachs include capelin, char, salmon, cod, sand lance, and sculpins. Invertebrates include a variety of shrimp, clams, annelid worms, squid, and crabs (ADF\&G, 1975). 
Optimum Sustainable Population

Except for a total of about 100 animals taken during the 1930 's, exploitation of the Cook Inlet stock has been virtually nil (ADF\&G, 1973a). Consequently, this stock should presently be at its pre-exploitation level, which would be considerably above the lower level of the range of OSP.

The subsistence harvest of the Bering and Beaufort Seas stock of beluga has never been substantial and, furthermore, has declined during the past two decades (ADF\&G, 1973a). The recent average annual harvest of 150-300 animals is small, particularly if it is noted that the available estimate of stock size is a minimum, although there is some additional loss of animals killed but not recovered. Consequently, this stock should not be greatly reduced below its pre-exploitation level and should be greater than the lower level of the range of OSP.

D. ECOLOGICAL RELATIONSHIPS OF MARINE MAMMALS IN WATERS OFF ALASKA

\section{General}

Ecological relationships of marine mammals in Alaska are largely determined by such factors as: the bodies of water they inhabit; their preference, if any, for ice or land; whether they congregate into dense herds or pods or are solitary; and whether they feed principally on bottom or pelagic organisms. Seasonal migration and seasonal movement of ice tend to change the Eeeding and social interactions. 


\section{Distribution}

Distribution is dependent to a large extent upon affinities for land or ice. Walrus, spotted seal, ribbon seal, ringed seal, and bearded seal utilize ice for pupping and for hauling out. Sea lions, harbor seals, and sea otters utilize land platforms for pupping and hauling out. Polar bears den on ice or land. Belugas and other whales do not require ice or land, although during some seasons they may be found closely associated with these features.

\section{$\underline{\text { Feeding }}$}

For convenience, nine general categories of food for marine mammals (except polar bears) can be addressed. These are: pelagic finfish, pelagic crustacea, pelagic molluscs, eephalopods, euphausiids, benthic and demersal fish, benthic crustacea, benthic molluscs, and other benthic invertebrates. Polar bears feed mainly on seals. Figures 12, 13, and 14 show the feeding relationships as a genera1ized scheme.

Placement of animals (in the diagram) in more than one location generally indicates seasonal migrations of these marine mammals. Not enough is known about which species of each prey category would form the major part of the diet of each marine mammal species or population stock, especially when the mammals move considerable distances seasonally. It is known, for example, that fur seals in the eastern Bering Sea at times feed heavily on Alaska pollock, that species having formed up to 70 percent of the stomach contents. At other times, squid form up to 80 percent of the stomach contents. The heavy consumption of salmon smolts by beluga whales in the mouths 

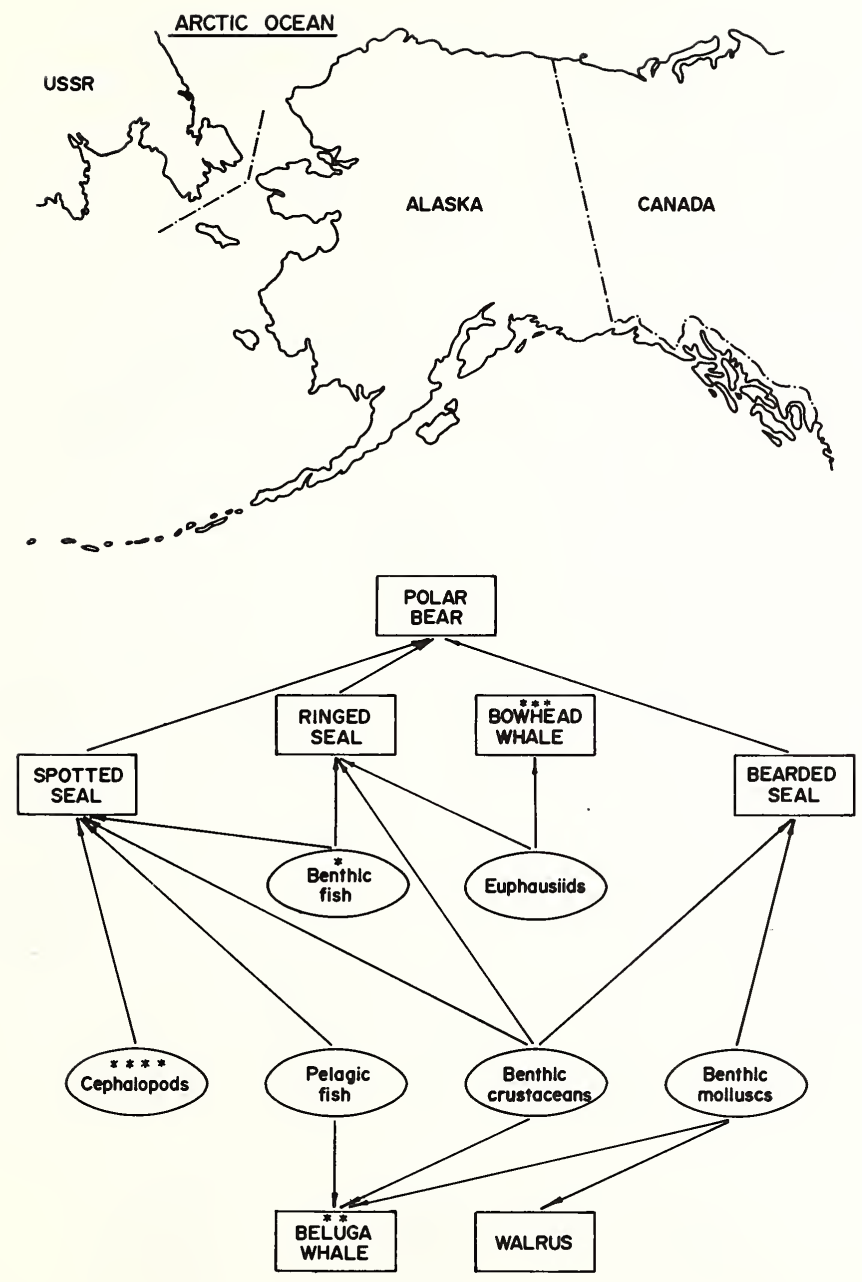

Figure 12: Marine Mammal Food Relationships in the Arctic Ocean

*Benthic fish includes demersal species

**Beluga whale includes other toothed species
***Bowhead whale includes other baleen species

****Cephalopods includes squid and octopus 


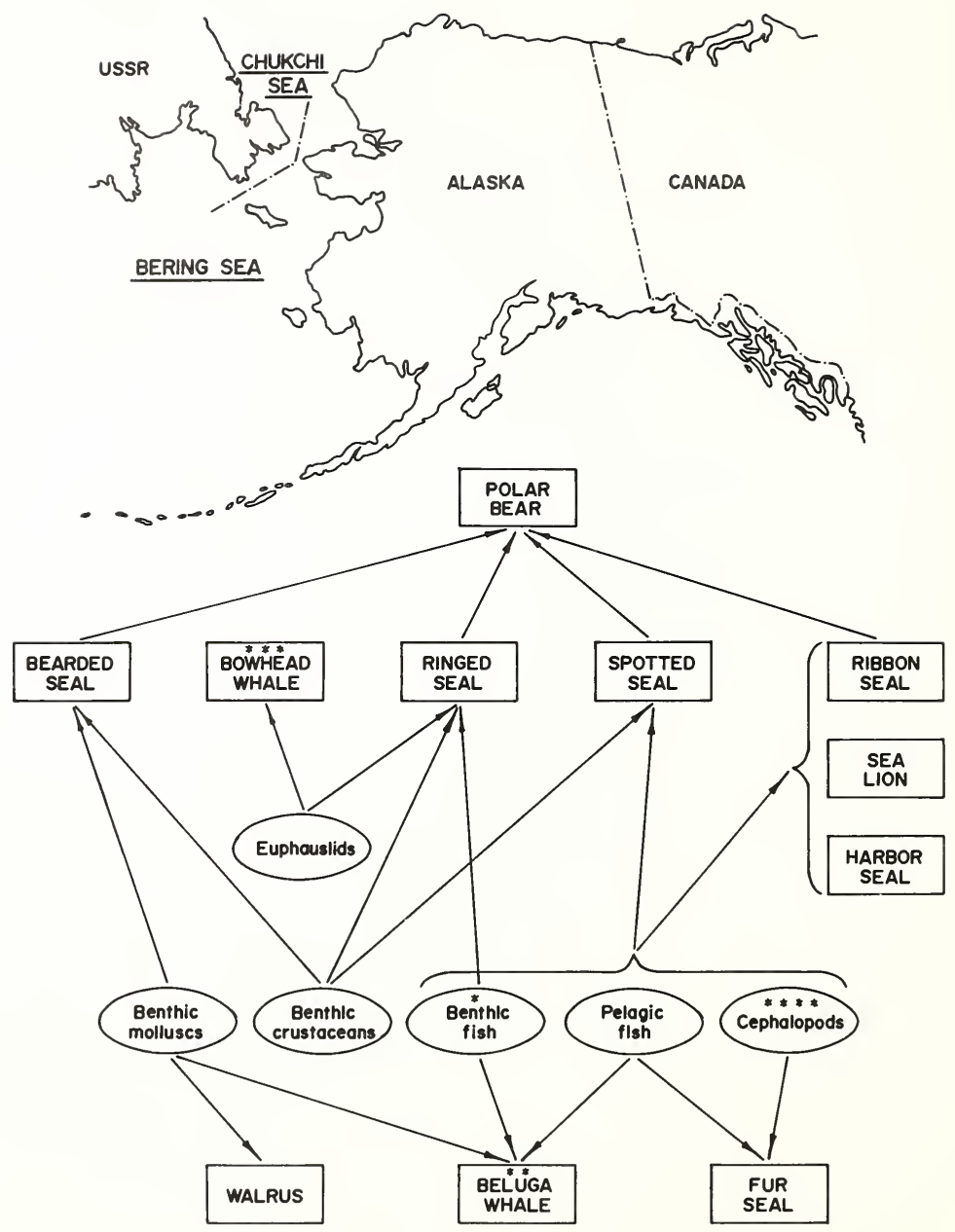

Figure 13: Marine Mammal Food Relationships in the Bering and Chukchi Scas

- Benthic fish includes demersal species

* Beluga whale includes other toothed species
* Bowhead whale includes other baleen species *** Cephalopods includes squid and octopus 

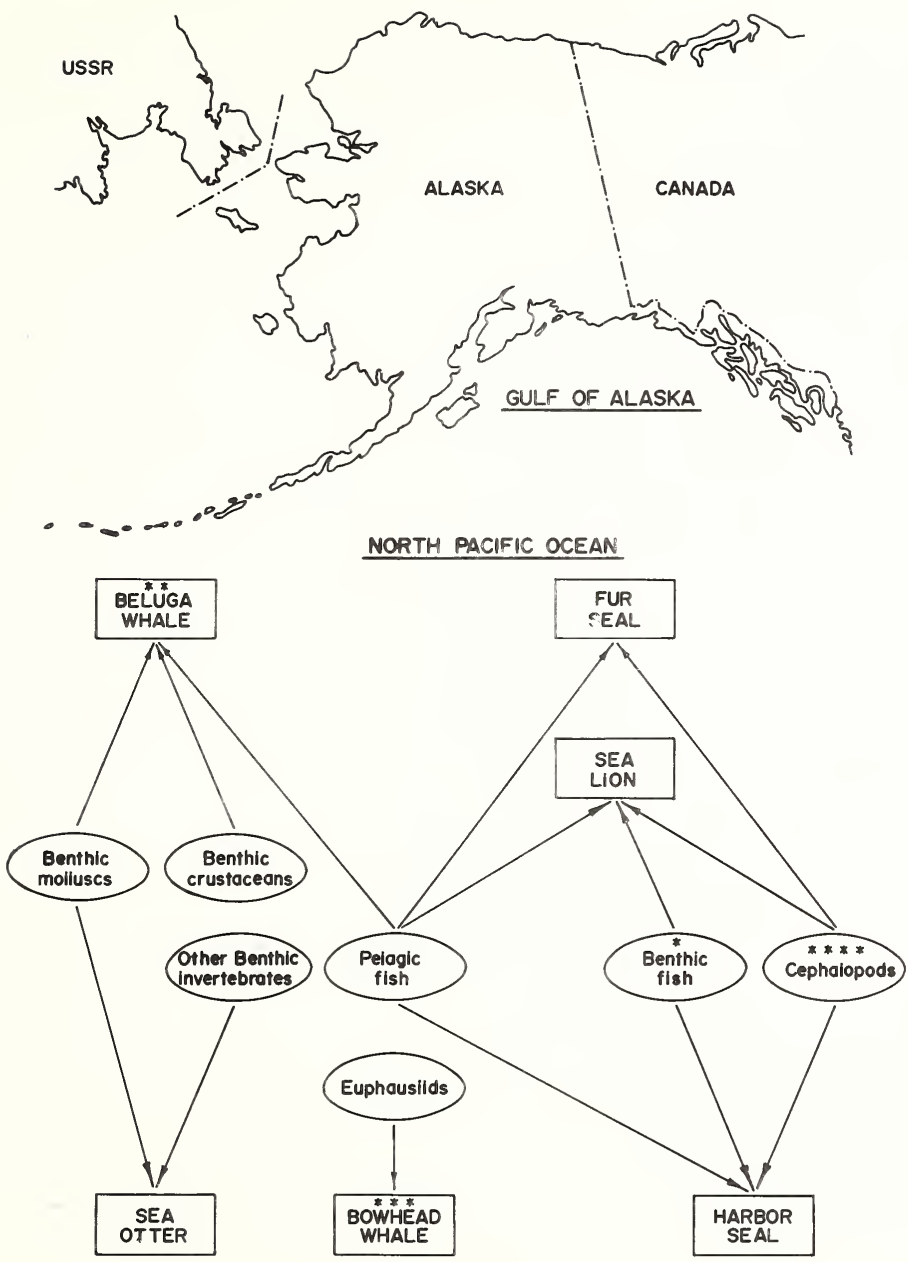

Figure 14: Marine Mammal Food Relationships in the North Pacific Ocean and Gulf of Alaska

*Benthic fish includes demersal species

**Beluga whale includes other toothed species
***Bowhead whale includes other baleen species

**** Cephalopods includes squid and octopus 
of salmon streams is well documented. In these and other cases, it is virtually impossible to show direct competition for these food items between the fur seal, on the one hand, and other pinnipeds eating benthic or demersal fish, or between beluga whales eating salmon smolts and some other whale or pinniped eating these same or similar fish. Very little direct competition between marine mammals is known at present; however, there may be strong secondary relationships (i.e., a target species of fish or shellfish, having been reduced by heavy predation, may be replaced in its niche by another species of fish or shellfish, or if two species of mammals were eating different fish that occupy similar habitats, then this predation might open the way for a third species of fish to dominate the habitat).

\section{Relationships in the Beaufort Sea-Chukchi Sea}

Ice seals, walrus, polar bear, beluga, and bow-head whales show no evidence of overcrowding. Ice seals tend to be solitary, aggregating at most into small groups; thus competition for space on the ice appears to be minimal. Even though no competition is evident, it has not been determined whether this distribution is or is not a limiting factor. The availability of ice seals as food for polar bear appears to be adequate for the population of bears, and the two groups may be "in balance" at this time (i.e., over 800,000 ice seals in north Bering-Chukchi-Beaufort Seas and up to 9,000 polar bears in the same area).

Ice seals and walrus are in partial competition insofar as bottomdwelling (benthic) molluscs and crustacea are concerned. Ice seals compete among themselves to a limited extent for benthic and pelagic 
organisms. However, only the ringed seal feeds to any extent on euphausiids, placing them in direct competition with bowhead whales (and probably other baleen whales).

The beluga whales (and possibly other toothed whales) probably compete directly with most of the ice seals for food but not for space. Except for those periods when belugas are found nearshore and in mouths of salmon streams, their whereabouts and habits are unknown; however, recently large numbers of belugas were seen near the edge of the pack ice in the Chukchi Sea during the summer months (Burns, oral communication to L. Croxton, Nay 1975).

\section{Relationships in the Bering Sea}

Walrus, ice seals, and beluga whales show no evidence of overcrowding at present. Sea lions, and harbor seals are near the carrying capacity of the environment and may in places be exceeding it (ADF\&G, 1975). Except for ice seals during most of the year, all of the above animals have strong social instincts and form some type of social grouping for a large part or all of the year. Thus, there is some competition for haul-out and pupping grounds, especially among the harem social systems. Large concentrations of animals, all utilizing the same food species, may tend to reduce the populations of food species locally, causing the predators to increase their foraging range. When other forces (such as intensive fishing) have partially depleted the food supply, the foraging sorties are increased, thereby providing direct evidence of how behavior of the predator animals can be influenced through their food supply (for example, the fur seal on the Pribilof Islands; NMFS, 1972). 
Among the marine mammals in the Bering Sea, there is no direct predation by one species on another, except occasional capture of fur seal pups by adult sea lions or predation by killer whales (ignoring the short intrusion of polar bears through the Bering Strait). On haulouts and rookeries such as St. Paul and St. George Islands, fur seals and sea lions have not been observed to display any aggressiveness toward each other.

Feeding competition, reflected by predation on the major prey groupings, appears to be widespread between all of the species throughout the Bering Sea. However, considering the movement of ice seals and walrus north and south with the ice pack, the migration of a majority of fur seals southward for upwards of 6 months, and the unknown movements of whales, it becomes apparent that physical dispersion of the predator animals themselves tends to limit this competition. Fay (testimony, 1975) stated that the walrus competes most with the bearded seal, whose diet seems to be similar during the spring and summer period. Almost nothing is known of the walrus diet in autumn and winter in the Bering Sea. The walrus also eats some of the same kinds of organisms taken by the harbor seal and by the gray whale, but these organisms are not taken in the same localities or in the same seasons.

\section{Relationships in the Aleutian Chain and Gulf of Alaska}

The ice seals, polar bear, and walrus are absent from the Aleutians and the Gulf of Alaska. Fur seals are temporary inhabitants; they either move through on their long migration southward and return, or they seasonally forage in the area. As stated in previous sections, sea lions 
and harbor seals appear to be at full population levels and may be utilizing all of the hauling out and rookery areas available. Some population stocks of sea otter have reached the full carrying capacity of the habitat; other population stocks are still growing.

In spite of the large populations of each species, 1ittle or no competition for space has been observed between species. Spaulding (1964) found little or no direct competition between fur seals, sea lions, and harbor seals in British Columbia. However, John Vania reported (written communication to L. Croxton, May 1975) that recently sea lions are increasing in some areas formerly predominantly occupied by harbor seals and that they appear to be in direct competition in these limited areas for food.

Each species of pinnipeds in this area competes with several other species for the major prey groups. Belugas and probably other toothed whales compete with several pinniped species. However, the baleen whales appear to be noncompetitive, feeding on organisms not generally eaten by the pinnipeds of the Gulf of Alaska. Studies of food habits of all marine mammals in the Gulf and along the Aleutian Chain are insufficient to determine whether competition for categories of prey is in fact competition for the same prey species.

\section{Relationships to the Ecosystem}

Bartonek and others (1974, page 24) discussed productivity in the Bering Sea and stated in part: 
"Most of the 25 species of Bering Sea marine mammals are part-time residents (Fay, 1974). Walrus and several kinds of seals and whales move down into the region in winter with the advancing sea ice from the north, whereas others move into the region from the south in the ice-free summer. Prorating their occurrence in terms of fulltime residence in the Bering Sea, the marine mammalian fauna is equivalent to 1.5 million full-time residents having a biomass (standing crop) of about 450,000 metric tons. They consume some 9 to 10 million tons of nekton and benthos annually (four times the commercial fisheries catch), converting at least 10 percent of that into new flesh and redistributing as feces more than one million tons of nutrients. These estimates are rough but conservative, and better data are needed for more realistic assessments.

Birds and mammals are an important system for transporting, both vertically and horizontally, energy and nutrients within the Bering Sea. For example, the tiny crested auklet (230 g) has been reported to dive to 120 meters to catch prey, and murres take their catch to young that are more than 88 $\mathrm{km}$ ( 40 miles) away at the nesting colony. Birds defecate in the water during feeding and also on the nesting cliffs. Guano defecated by these birds may exceed 100,000 metric tons per year; however, guano accumulation in colonies is negligible because precipitation erodes the deposits--thereby carrying most nutrients back to the sea."

Fay (testimony, 1975) stated that the Pacific walrus, by its grazing and rooting activities while in search of food, probably turns over or tills, several million tons of bottom sediments in the Bering and Chukchi Seas each year. This tilling releases nutrients that might otherwise by trapped indefinitely in those sediments. These released nutrients could then contribute to the high productivity of the waters in this area. 
E. THE PEOPLE, THE ECONOMY, AND HUNTING PRESSURES IN ALASKA

Nearly half of the Alaskan population lives along the "Railbelt," a strip 50 miles wide that follows the route of the Alaska Railroad from the seaport at Seward north through Anchorage to its terminus at Fairbanks. Other population centers include the southeastern panhandle, Kodiak, Nome, and some 250 scattered, small villages.

1. The Census and Current Population Estimates

Alaska's official population in 1970 was 302,173 (ADL, 1970)--up from 226,167 in 1960. In 1972 it was estimated to be 324,281 (ADL, ND). In recent years, pipeline construction has attracted a large number of immigrants. However, civilian migration to Alaska, although a large factor in population increase, must be compared to the natural increase lest it be overemphasized. From 1950 to 1960, when Alaska's population increased by nearly 100,000 persons, natural increase accounted for over 60 percent of the gain. Net civilian migration accounted for over 25 percent, and military personnel constituted the balance. Between 1960 and 1970, 81 percent of the 76,000-person increase was due to natura1 increase. Only 72 percent of the 1970-71 increase was attributed to natural increase, considerably less than the rate of the previous decade. Increases in military population were significant in Alaska's growth up to 1960 , after which it has remained fairly stable at about 33,000 persons. From 500 persons in 1940, the military population increased to over 150,000 during World War II, then decreased to about 20,000 in the 1950 census. It rose again to about 50,000 during the Korean War. In 1970, the military population comprised 10.4 percent of Alaska's total, while in 1971 the military component further declined to 9.6 percent (ADED, 1972) . 
Population growth has continued, although the rate of increase may be slowing. In the table below, the estimates of population for several years since the census, including a projection for 1976, are compared with the 1970 census:

\begin{tabular}{lll} 
Year & Estimated population & Source \\
\cline { 2 - 3 } & 300,382 (census) & ADED, 1972 \\
1970 & 324,281 & ADL, ND \\
1973 & 328,670 & ADL, ND \\
1974 & 337,000 & Bur Census, 1974 \\
1976 & 404,000 & ADF\&G, IID
\end{tabular}

The bulk of the population resides in two cities, Anchorage and Fairbanks. In the two coastal districts which border on the Bering and Chukchi Seas, where the subsistence hunting of marine mammals occurs, the Eskimo and Aleut populations totaled 24,416 in 1972 (ADL, ND).

Although the population as a whole in Alaska has increased at a very rapid rate, Native populations have not increased at a comparable rate. The comparative rates of growth for the population as a whole between 1880 and 1972, Native and non-Native, are given below:

\begin{tabular}{lrrr} 
Year & Native & Non-Native & Total \\
\cline { 2 - 3 } 1880 & 32,996 & 430 & 33,426 \\
1890 & 25,354 & 4,298 & 32,052 \\
1900 & 29,542 & 30,450 & 63,592 \\
1910 & 25,331 & 36,400 & 64,356 \\
1920 & 26,558 & 28,478 & 55,036 \\
1930 & 29,983 & 29,295 & 59,278 \\
1940 & 32,458 & 40,066 & 72,524 \\
1950 & 33,863 & 94,780 & 128,643 \\
1960 & 43,081 & 183,086 & 226,167 \\
1970 & 50,554 & 251,619 & 302,173 \\
1972 & 53,187 & 271,094 & 324,281
\end{tabular}

(Source of data page 12, ADED, 1972, and ADL, ND) 
2. Regional Distribution, Natives and Non-Natives

The 1972 popuiation estimates of the five regions have been broken out for racial and ethnic groups by the Employment Security Division of the Alaska Department of Labor (ADL, ND). Alaska Department of Fish and Game has made regional estimates for 1976 but has not identified Native and non-Native. These regional estimates for 1972 and 1976 are shown in the table below:

\begin{tabular}{|c|c|c|c|c|c|}
\hline \multirow[b]{2}{*}{ Region } & \multicolumn{3}{|c|}{1972 Population Estimate } & \multicolumn{2}{|r|}{$\begin{array}{c}1976 \\
\text { Population }\end{array}$} \\
\hline & Indians & Eskimos and Aleuts & Non-Natives & $\underline{T o t a 15 /}$ & estimate \\
\hline Southeast & 7,563 & 689 & 36,520 & 44,772 & 55,800 \\
\hline Southcentral & 3,449 & 6,740 & 172,765 & 182,954 & 233,300 \\
\hline Southwest & 1,098 & 13,468 & 8,376 & 22,942 & 28,300 \\
\hline Interior & 3,681 & 4,571 & 50,551 & 58,803 & 69,600 \\
\hline Northwest & 980 & 10,948 & 2,882 & 14,810 & 17,400 \\
\hline
\end{tabular}

3. The Alaskan Native Economy

In describing the economic circumstances of the Alaska Native population, the Federal Field Committee for Development Planning in Alaska (FitzGerald, 1968) stated that a great contrast exists between the generally high income and moderate standard of living and the Natives' appallingly low income and standard of living and the virtual absence of opportunity for most Eskimos, Indians, and Aleuts of Alaska. This segment of the population springs from cultures very different from those of other Alaskans or other Americans. Most of them live in widely

5/ Total also includes white, black, oriental, and others. 
scattered settlements across the half-million square miles of Alaska. In an economy based importantly in a pattern of life of subsistence fishing and hunting, the large majority of these native Alaskans are unemployed or only seasonally employed. Although some families have annual incomes of $\$ 5,000$ or more, most of them live in poverty.

Economic development in Alaska is concentrated along the narrow coastal belt from southeastern Alaska to Kodiak and Bristol Bay and inland along the so-called railbelt area. The vast expanse of land north and west of the railbelt area has undergone little development. Most of the existing development is the remnants of the early mining and trading days, plus a few new military installations.

Reliance upon hunting and food-gathering activities for subsistence is a distinctive characteristic of an Alaskan village, but it is only one feature of the Native economy. Jobs in the villages are few; permanent full-time jobs at highest rates of pay are typically held by non-Natives. Seasonal or other temporary jobs, usually low paying, are often held by Natives; unemployment and underemployment rates among Natives are probably higher than among any other ethnic group in the Nation. Self-employment for cash in villages is usually part-time. Principal pursuits are fishing and trapping, arts and crafts production, and operation of small cafes, stores, recreation halls, or movie houses. Cash payments to some 1,200 Eskimo Scouts of the Alaska National Guard for drills total about $\$ 800,000$ annually. Most of this goes to the 
economies of the 65 villages in western Alaska. Unemployment benefits and social security are important to the village economy, particularly for the cash they provide in the winter. Also important for the same reason are welfare checks going to the old, the blind, the disabled, the needy having dependent children, and to the temporarily needy. Prices are high in Alaskan villages, and for Natives, income is low. By any measure, most of Alaska's villagers are living in poverty (FitzGerald, 1968).

Heller and Scott, as cited by J. H. FitzGerald,(1968), stated that the desire for purchasable goods is the primary motive prompting increasing numbers of Natives to seek seasonal wage work. This results in a continuing modification of many of the seasonal food-gathering activities, especially those normally occurring from late spring to about mid-fall. In years when work for wages is not generally available, there may be an increase in local hunting and fishing activities, but in most villages there is a continuing decrease in the number of families who follow traditional food-quest patterns.

Villagers also gather local resources in order to obtain the cash needed for imported products upon which they are increasingly dependent. Walrus ivory and whale baleen usually are sold as art or craft objects, but raw ivory finds buyers among carvers who are not walrus hunters.

\section{Hunting Pressures}

Some indication of the hunting pressures on game and marine mammals that result from the increased population can be realized from records 
of sale of hunting licenses. For the years 1959 through 1974, the hunting license sales (ADF\&G, 1975) for resident, nonresident, and subsistence are given below.

\section{License}

Calendar year $\$ 7.00$ resident hunting $\$ 10.00$ nonres. hinting Subsis. $\$ 0.25$

$\begin{array}{lrrr}1959 & 27,517 & & \\ 1960 & 30,376 & & 3,005 \\ 1961 & 34,519 & & 2,925 \\ 1962 & 34,609 & 4,842 & 4,728 \\ 1963 * & 36,453 & 4,946 & 5,882 \\ 1964^{*} & 37,183 & 6,288 & 5,048 \\ 1965 & 37,667 & 6,795 & 4,664 \\ 1966 & 36,086 & 7,717 & 4,354 \\ 1967 & 35,182 & 9,199 & 4,919 \\ 1968 & 39,977 & 10,560 & 5,085 \\ 1969 & 43,713 & 12,519 & 5,359 \\ 1970 & 50,096 & 11,525 & 5,595 \\ 1971 & 52,160 & 11,669 & 5,936 \\ 1972 & 52,811 & 8,728 & 6,658 \\ 1973 & 60,214 & 8,340 & 6,256 \\ 1974 & 59,441 & & \end{array}$

* Fiscal year. Calendar year not available.

The Federal Field Committee stated in 1968 (FitzGerald, 1968)

that most village Alaskans subsist in some measure by hunting, fishing, and trapping; by gathering berries and greens; by using animal skins in garment making; and by gathering driftwood, timber, or willows for fuel. There is generally greater dependence upon food gathering in western and northern Alaska than in other regions.

The increased demand, if any, for marine mammals generated by increasing human populations is not known. New residents of the State of Alaska, if they do hunt, are expected to favor such big-game animals as moose, caribou, deer, sheep, and goats. 
Native subsistence dependency has decreased since the white man began to colonize Alaska. The granting of 40 million acres in fee title land and nearly $\$ 1$ billion to the Natives under provisions of the Alaska Native Claims Settlement Act (ANCSA) should accelerate this trend. It has been said that ANOSA will have as great an impact upor the Alaska Native's traditional way of life as did their early encounter with white man's culture. (For a differing viewpoint, however, see comments by David Friday, Chivak chairman, in Chapter IX of this document).

The increase in population related to timber development is centered in southeastern Alaska. It should generate very little increase in demand for the marine mammals.

Much of the human population increase related to oil development and extraction is located away from the coast but may generate some additional sport hunting for polar bear, walrus, and harbor seal. 
With passage of the Marine Mammal Protection Act on October 21, 1972, and its implementation on December 21, 1972, the legal taking of marine mammals in Alaska--other than by Indians, Eskimos, and Aleuts--ceased, except by specific Federal permits for scientific research, public display, or incidental to commercial fishing operations. The taking of marine mammals by Alaska Natives has been liberalized for most of the nine species as a result of the Act. As the State interpreted the Act, its regulations were no longer applicable, and areas in which seasons were restricted or closed, or in which bag limits applied, were now open to hunting by Natives. For example, State of Alaska regulations on walrus, in effect before enactment of the Act, placed a limit of five adult cows or subadults (of either sex) upon walrus subsistence hunters. Walrus hunting was not allowed in Game Management Units 9 and 17 (the Alaska Peninsula and Bristol Bay). Additionally, the Walris Islands, in northwestern Bristol Bay, were designated as a State game sanctuary. When the Act was passed and the Native exemption became effective, the State suspended enforcement against Native subsistence hunting in all areas and restrictions ceased on the number of cows or subadults that may be taken.* The State also had maintained a continual closed season on sea otters except on an experimental basis. However, the Act allowed the unrestricted harvest of sea otters for Native subsistence and cottage industries. State regulations had prohibited the taking of polar bear cubs and females accompanied by cubs, and they had allowed the taking of no more than two polar bears (except cubs and sows with cubs) for subsistence purposes. The Act placed no restrictions upon the taking

* On April 5, 1976, the Director, FWS, implemented a waiver of the moratorium on the taking of Pacific Walrus and returned management to the State of Alaska for that species, and State regulations were reinstated for all citizens of the State. 
of polar bears for Native subsistence or cottage industries. The takings proposed under Federal and State regulations must be viewed in the perspective of takings which are currently allowed under the Act as well as takings which are beyond the scope of the Act. These current takings are detailed in section B. below.

A. ANNUAL TAKING FOR SPORT, COMMERCIAL, AND SUBSISTENCE PURPOSES

Marine mammals are taken by hunters for three general purposes: sport, commercial value, and subsistence.

Sport harvest constitutes only a small portion of the number of most species of marine mammals taken by hunters. In the past, only the sport harvest of polar bears has exceeded the harvest for other purposes. Under the moratorium imposed by the Act, polar bears can be taken only by Natives for subsistence or for creating and selling authentic articles of handicraft and clothing.

The requested waiver and proposed regulations by the State of Alaska would allow an estimated 250 polar bears to be taken annually for both subsistence and sport purposes. The ALJ recommended that the take be limited to 170 animals (ALJ, 1977, p. 86).

About 1,650 walruses had been harvested annually by the Natives for subsistence purposes and for their cottage industries prior to the Act. Since the imposition of the moratorium, however, the Native take has increased somewhat. The first year of the existing waiver saw a take of over 2,900 animals. Consequent1y, on May 20, 1977, FWS approved the State's amended regulations, which established limits by game units and localities to reduce the annual retrieved take to or below the State's intended maximum of 2,300 animals (42 F.R. 25924). 
The majority of the sea lions and land-breeding harbor seals previously taken by hunters were harvested for the commercial value of their pelts. The harvest of sea lions was almost totally confined to pups. The harvest of harbor seals consisted of both pups and adult animals. The numbers of marine mammals harvested in Alaska from 1968 to 1972 are shown in table 3 .

Table 3. Harvests of marine mammals in Alaska, 1968-72, These harvests include only species on which there was a commercial or sport hunt, but the data include subsistence take whenever that occurred $\underline{1}$ /

$\begin{array}{lrrrrrr}\text { Sport hunted species. } & 1968 & \underline{1969} & \underline{1970} & \underline{1971} & \underline{1972} & \begin{array}{l}\text { 5-year } \\ \text { average }\end{array} \\ \text { Polar bear 2/ } & 351 & 298 & 316 & 203 & 265 & 287 \\ \text { Walrus 2/ } & 1,436 & 882 & 1,422 & 1,915 & 1,325 & 1,396\end{array}$

Commercially hunted species:

\begin{tabular}{|c|c|c|c|c|c|c|}
\hline Sea lion $3 / 4 /$ & 4,118 & 5,208 & 6,075 & 3,314 & 6,924 & 5,128 \\
\hline $\begin{array}{l}\text { Harbor seal } 2 / 5 / \\
\quad \text { (land-breeding) }\end{array}$ & 8,000 & 10,000 & 10,000 & 10,000 & 12,000 & 10,000 \\
\hline
\end{tabular}

Experimentally harvested species:

$\begin{array}{llllllll}\text { Sea otter } & 6 / & 1,016 & 251 & 1,088 & 183 & 57 & 519\end{array}$

1/ Data supplied by ADF\&G.

2/ Includes some subsistence take; see table 4 .

3/ Almost totally pups.

4/ Estimated harvest.

5/ Includes both pups and adults.

6/ Includes sea otters transplanted, harvested by ADF\&G, and accidental mortalities. The 1971 figure does not include an estimated 1,000 to 1,350 otters killed at Amchitka Island by nuclear test "Cannikin." 
B. CURRENT TAKINGS OF MARINE MAMMALS IN ALASKA NOT AFFECTED BY THE REQUEŚTED ACTION

Certain takings (or mortalities in some instances) were either (1) allowed to take place under provisions of the Act and the Federal Regulations or (2) are in general outside the jurisdiction of the Act (e.g., foreign incidental take). Although some specifics will be given in the sections that follow, these two categories enumerated above are not expected to be changed materially by promulgation of regulations, waiver of the moratorium, and transfer of authority to the State.

1. Takings Allowed Under Provisions of the Act and the Federal Regulations

The language of the Act and the regulations thereunder (39 F.R. 1854 and 39 F.R. 7262) provide for special and general exceptions to the moratorium.

\section{Special Exceptions}

Section 18.31 and section 216.31 provide for special exceptions to the moratorium under either scientific research permits or public display permits.

\section{a. Scientific Research Permits}

The largest requirements for specimens of Alaskan marine mammals for research are those of the $A D F \& G$. For the most part, it is anticipated that the $A D F \& G$ would provide material needed for conducting research by cooperating organizations. Examples of such collaborative efforts include: blood samples for population 'identification-University of Alaska, Institute of Arctic Biology; tissue samples for pesticide and heavy metals analysis--State of Alaska Department of Health and Welfare and University of Alaska; parasite studies--State of Alaska and Arctic Health Research Center; investigations of 
tissue enzymes-University of Alaska and Arctic Health Research Center; and taxonomy and systematics $n$ State of Alaska and Arctic Health Research Center.

Separate applications for taking marine mammals for research purposes were received from several individual scientists, from the U.S. Fish and Wildlife Service, and from the National Marine Fisheries Service. Examination of the requests for scientific research permits in 1974 and part of 1975 has provided data for anticipated requests for this activity in the immediate future. These are summarized in table 4.

\section{b. Public Display Permits}

There have been relatively few requests since passage of the Act for permits to capture animals in Alaskan waters for display purposes. Alaskan species whose ranges extend southward have generally been taken as far south as possible to minimize the difficulties of operating conditions and transportation distances. Thus, the 1973-74 applications included requests for 4 killer whales, to be captured in the waters off Mexico, Washington, and Alaska; 4 belugas to be taken in Hudson Bay or Alaska; 16 harbor seals to be captured in the Bering Sea; and 12 walrus pups to be taken in Alaska in 1973 and 8 in 1974 .

Fourteen of these animals were taken in waters off Alaska. One additional request was received in 1973 to collect four ringed, two bearded, and two ribbon seals.

Since 1973, no additional public display permits have been issued authorizing taking in Alaska. However, there are a number of species of marine mammals now on display for which replacement requests can be anticipated in the future. 


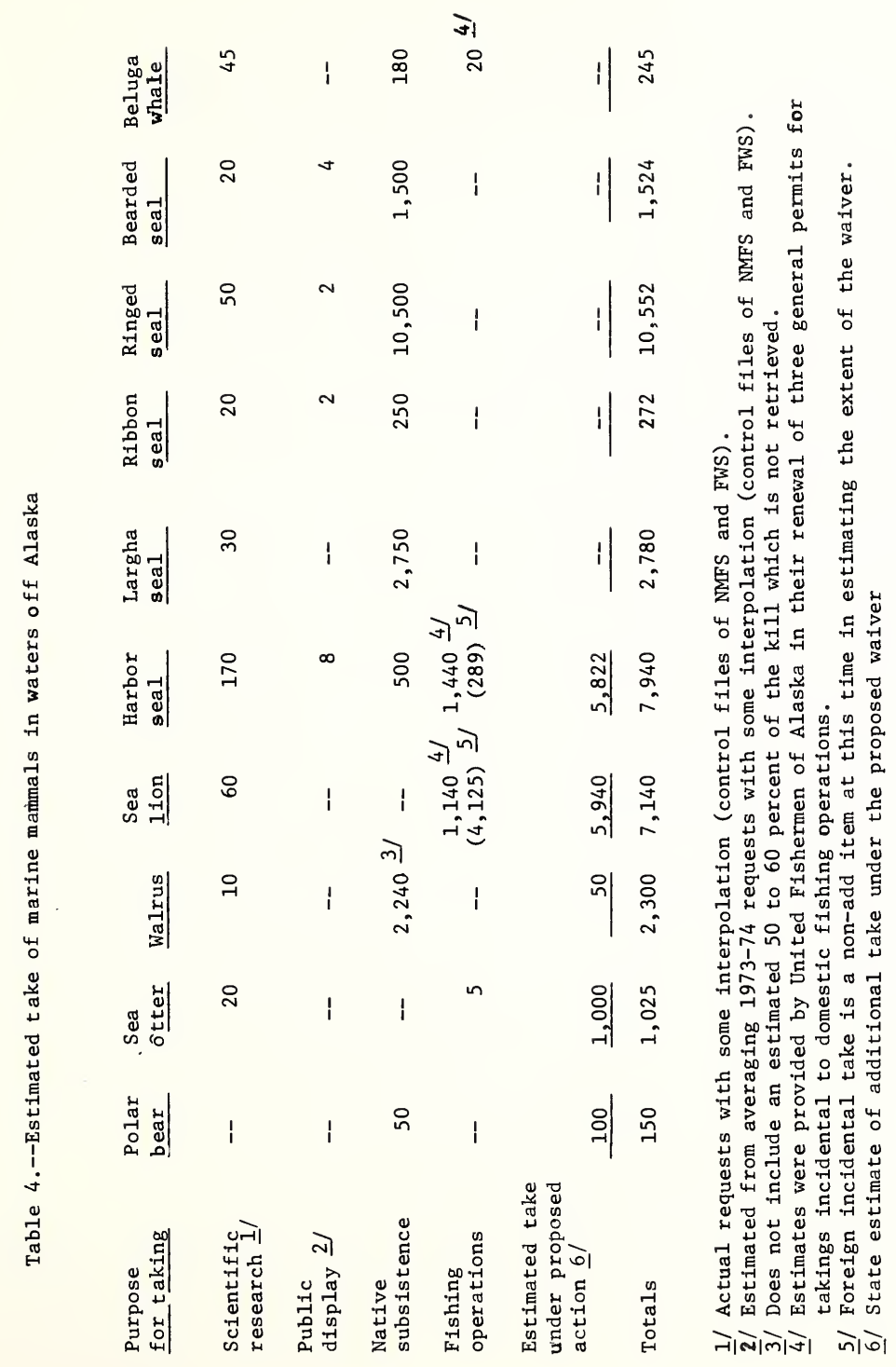


Additionally, other Alaskan species not now commonly displayed can be expected in requests of the future as handling techniques improve, more persons become proficient in the art, and as transportation problems (long distance) are solved (see Sea World report $6 /$ ). Numbers of animals in public display permits are summarized in table 4.

\section{General Exceptions}

The language of the Act and the regulations thereof (39 F.R. 1854 and 39 F.R. 7262) under "General Exceptions" exclude certain activities under international treaties and also provide for several classes of takings as exceptions to the moratorium, especially Sections "18.21 and 216.21 Actions permitted by international treaty, convention, or agreement", "18.23 and 216.23 Native exceptions", and "18.24 and 216.24 Taking incidental to commercial fishing operations." These are discussed below under the headings (a) Hunting by Alaska Natives, and (b) Mortality due to Domestic Fishing Operations.

\section{a. Hunting by Alaska Natives}

Sections 18.23 and 216.23 of the regulations state: "(a) ... any Indian, Aleut, or Eskimo who resides on the coast of the North Pacific Ocean or the Arctic Ocean may take any marine mammal without permit if such taking is:

(1) By Alaskan Natives who reside in Alaska for subsistence, or

(2) For purposes of creating and selling authentic Native articles of handicraft and clothing, and in each case, not accomplished in a wasteful manner."

6/ Letter from Sea World to Mr. Robert W. Schoning, dated January 15, 1974, reporting on acquisition of animals under Letter of Exemption as required under section 101 (c) of the Marine Mammal Protection Act. 
Almost the entire haryest of ice-inhabiting seals and walruses, and all of the harvest of beluga whales, is by Eskimo hunters. With respect to northern (Steller) sea lions, the ADF\&G stated that although these animals were once extensively used by coastal dwelling Natives for subsistence purposes, today there is little subsistence use of this resource (ADF\&G, 1973a).

The ice-inhabiting seals have a long history of use by coastal residents. These seals are a dependable and basic source of food and articles of local use, and they provide several commodities which create a cash income. In the 5-year period 1968-72, the Native harvest of ice seals averaged 15,248 animals annua11y. The ADF\&G anticipated a future average of 15,000 per year (ADF\&G, 1973a); however, they reported an estimated subsistence harvest of less than 8,000 annually in 1973 and 1974 (Grauvogel, 1974). Should the take increase as predicted by the $A D F \& G$, the state would be required to limit the harvest of each species to the extent of the waiver. In Bristol Bay, only a few belugas are taken; the estimated annual harvest for the Bering Sea-Arctic Ocean coasts is 150 to 300 , and the projected average annual harvest is 180 whales. $A D F \& G$ would limit future take to 10 from the Cook Inlet, and 350 from the Bristol Bay-Bering Sea stock. The Alaska Department of Fish and Game reports that there is no significant harvest of porpoises and dolphins in the area, and the hunting of other whales is mostly confined to grays and bowheads by Alaskan Natives.

b. Mortality due to Domestic Fishing Operations

In the U.S. fisheries, the principal conflicts with marine mammals (other than porpoise in the tuna fishery) involve seals and sea lions along the conterminous U.S. west coast and in Alaska. The marine mammal populations affected are 
large, and the majority of the involvements are the result of direct and sometimes intense competition between fishermen and marine mammals for the available stocks of fish. No data are available on numbers of sea lions killed by salmon fishermen to protect their gear or catch or in retaliation for losses of gear and fish. Also, no data have been collected on the number of sea lions killed by crab fishermen in order to protect their gear or in retaliation for lost gear. Neither do authorities have data on the actual number of seals killed by fishermen.

Belugas, unlike sea lions, prey only on freemswimming fish. It is believed that fishermen in Cook Inlet and Bristol Bay kill very few whales in the course of commercial fishing operations, and only on rare occasions does a whale become entangled in a gill net and drown. The number of belugas killed in all fishing operations is unknown but is believed to be small.

On March 14, 1977, the United Fishermen of Alaska (UFA) were granted a renewa1 by NMFS for three general permits (stationary gear; encircling gear, and other gear) for their members to take marine mammals incidental to their fishing in Alaskan and other Pacific coast waters. One requirement for obtaining the permits is submission of estimates of numbers and kinds of marine mammals which might be taken under such permits. On the basis of experience gained over several fishing seasons, UFA was able to give more accurate estimates than had been possible in previous years. The largest estimated incidental take is 2,380 sea lions, 2,880 harbor seals, 20 belugas, and 5 sea otters. However, it is not known how many of these animals are killed or die subsequent to release since the fishermen do not report their take levels individually at the clase of each fishing season. 
2. Takings Beyond the Jurisdiction of the Act and Federal Regulations

Although the Act prescribes that protected marine mammals or their products may not be imported into the United States, hunting by Soviet nationals in Siberian or international waters and whaling by foreign fleets in international waters is outside the jurisdiction of the Act. However, because of the 1976 amendments to the Act, takings by foreign nationals and vessels within the U.S. Fishery Conservation Zone (the outer limit of which is in most instances, 200 miles from the U.S. coastline) are forbidden without a permit issued under the Act.

\section{a. Takings by Soviet Hunters}

Renewed interest by the U.S.S.R. in commercial exploitation of ice seals in the Pacific sector of the Arctic in the early 1960's and subsequent Soviet harvests of these mammals had caused a decline in the population of ribbon seals. The U.S.S.R. constructed a fleet of modern sealing vessels, some of which now operate in the Pacific Arctic. Pinnipeds now being exploited include harbor, ringed, bearded, and ribbon seals, and northern sea lions. The skinned carcasses of seals have been seen on the ice, and Soviet sealers have been observed in the vicinity of St. Lawrence, King, and Little Diomede Islands. Crude estimates made in 1971 of the total annual kill of marine mammals by Soviets and Alaskans include 50,000 to 75,000 animals. The United States and the U.S.S.R. held informal meetings in 1970 and 1972 to exchange information on ice seals. Subsequently, the U.S.S.R. has supplied data on the harvest of each species of phocid seals and walruses in the Bering and Chukchi Seas for the period 1966-72. Table 5 shows 1972 Soviet harvest figures for 6 years. The harvests of seals has averaged 13,000 per year during that period; that of walruses, 1,400. 
Table 5.--Estimates of recent takings of marine mammals in waters off Alaska by Soviet hunters.

\begin{tabular}{|c|c|}
\hline Walrus & 1,518 피 \\
\hline Largha seal & $4,855^{21}$ \\
\hline Ribbon seal & 2,815 \\
\hline Ringed seal & 4,095 \\
\hline Bearded seal & 1,428 \\
\hline Total & 14,711 \\
\hline
\end{tabular}

1/ Does not include an estimated 40 to 50 percent of kill not retrieved.

2/ Currently 3,000-4,000 seals, of which 1,000-1,500 belong to the Alaskan stock. 


\section{b. Mortality Incidental to Foreign Fishing Operations}

Since the passage of the Marine Mammal Protection Act, the NMFS has sought and obtained data on incidental takings by foreign fleets, which were derived principally from observations by NMFS enforcement agents and from scientific observers with foreign fleets. Upon passage of the Fishery Conservation and Management Act of 1976 (16 U.S.C. 1801), the United States was given authority and implemented the placing of observers aboard all foreign fishing vessels which were fishing within the U.S. fishery conservation zone under a Governing International Fishery Agreement.

Although actual numbers on mortality levels will not be available until this new observer program is fully operational, the NMFS(NWFC) estimates that the incidental sea lion mortality from both domestic and foreign fishing operations is about 6,500 animals in the Bering Sea and Northeast Pacific Ocean. The foreign take is currently estimated to be about 4,125 animals of which an estimated 1,152 are killed.* Tables 6 and 7, intoduced during the 1976 hearing, summarize the information recently obtained from both observers and discussions with foreign fishermen on the incidental take of sea lions. The incidental take of other species affected by the waiver is insignificant as. these species usually do not come into contact with the foreign fleets.

\section{SUMMARY OF ESTIMATED AVERAGE ANNUAL TAKE OF MARINE MAMMALS}

A summary of estimated average annual take of marine mammals in Alaska under a State management program, based upon the average takings prior to the Act, is shown in table 4. It should be noted that these summary figures include only the number of animals which would be taken in a manner which would remove them * A general permit allowing foreign fishermen to take marine mammals during commercial fishing operations within the U.S. fishery conservation zone was issued allowing a take of 4,901 seals and sea lions during 1977. 


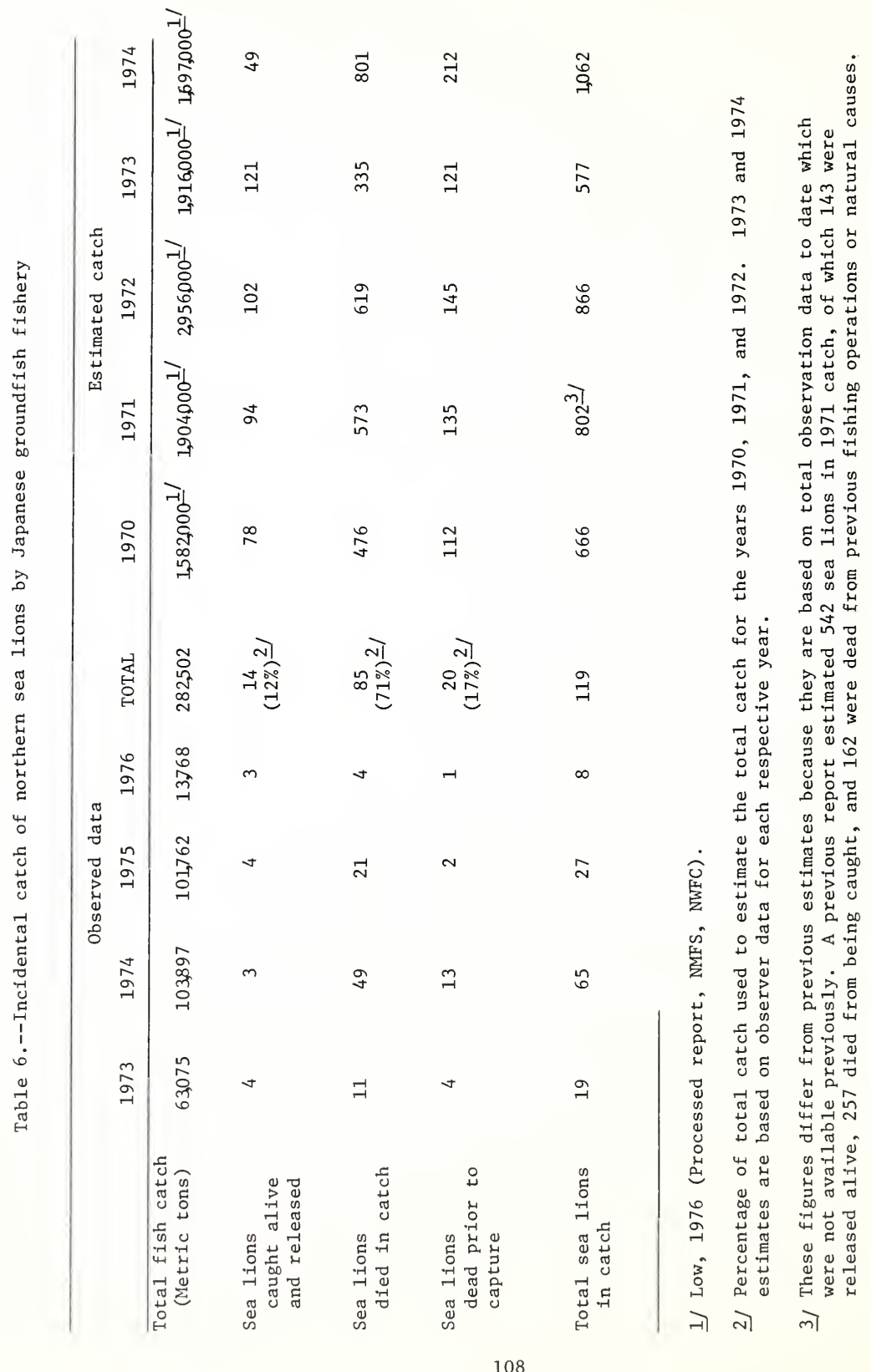




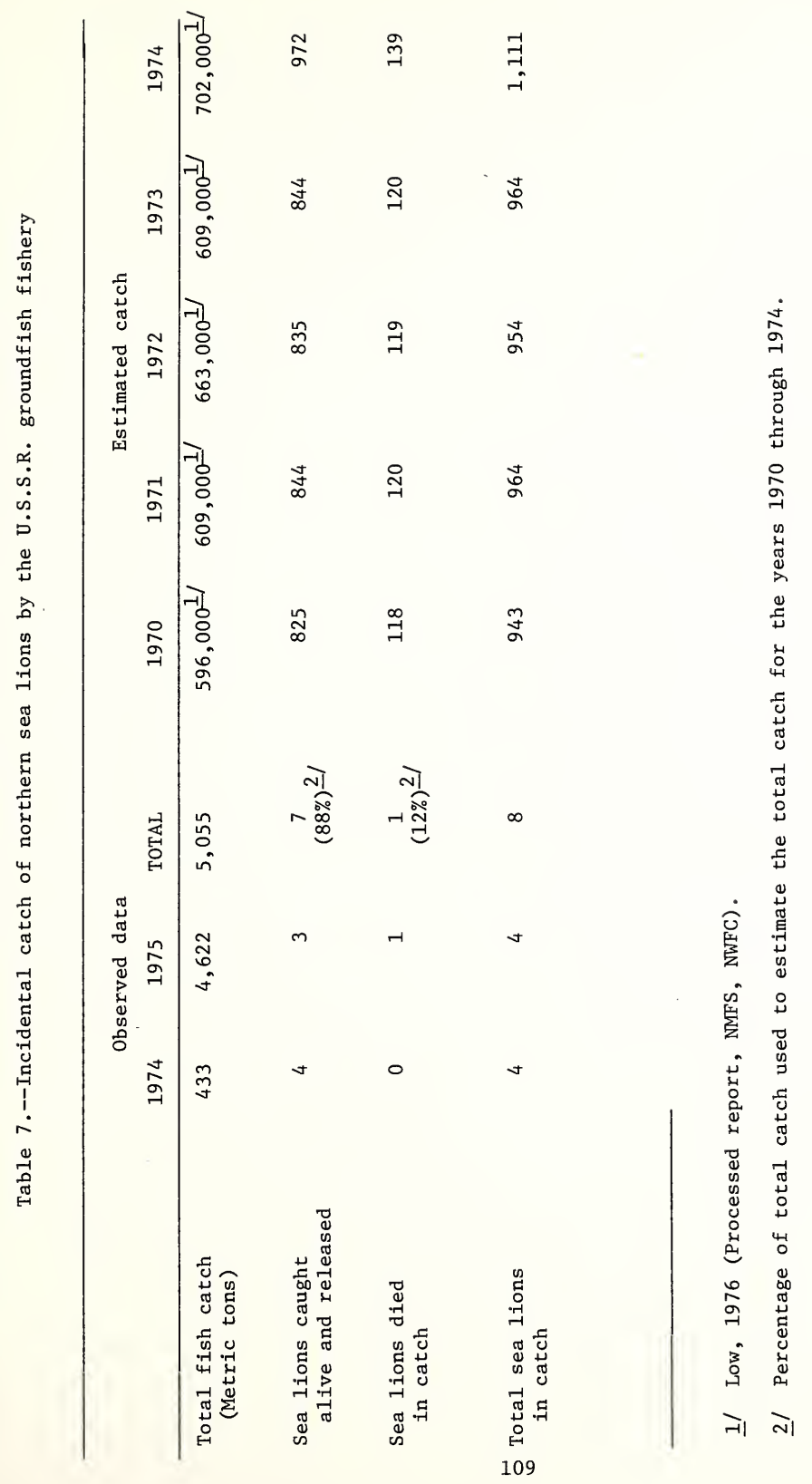


from the population. For example, in a request for a scientific research permit, if the intent were for animals to be tranquilized, tagged, measured, and then released, these animals would not be included in this summary total. Shown separately are estimates of takings incidental to domestic fishing operations.

D. THE IMPACT OF THE PROPOSED FEDERAL REGULATIONS AND THE STATE MANAGEMENT
PROGRAM 1. Impact on Species Populations

\section{Polar Bear (Ursus maritimus)}

The effect of the proposed regulations would be to allow up to 250 bears to be taken annually for sport and subsistence purposes.

No aircraft or large motorized vessels would be allowed to be used, and the actual harvest probably would be significantly lower than the ceiling of 250 animals. Harvests greater than this were sustained for 13 years prior to the Act with no measurable effect upon population size (ADF\&G, 1973a). Harvests of this magnitude would therefore not be expected to diminish the population stocks below their optimum sustainable levels (ADF\&G, 1975).

The ALJ (1977, p. 86) recommended a harvest not exceeding 170 animals, which he found would result in no significant effect on the optimum level of the population.

State regulations would permit the taking of polar bear in defense of life or property; however, game thus taken is the property of the State and must be surrendered to the State immediately. Surrender of the animal carcass is designed to prevent abuse of this exemption for sport or commercial purposes. 
Proposed State regulations would allow licensed residents to take one polar bear per year for food without a permit; however, such bears could not be taken, transported from the point of taking, or imported with the aid of aircraft. Geographical distances from non-Native residents, seasonable availability, and dispersal of the bears have acted to prevent use of this exemption for commercial exploitation. Increased human activity attendant to industrial development will lead to increased encounters between humans and bear populations. In the Alaskan Arctic, such problems will be minimal because onshore denning is not concentrated, nor do large numbers of bears trave1 overland. The potential impact of increased human activity is not assessable.

\section{Sea Otter (Enhydra 1utris)}

Under State regulations, no subsistence takings or hunting of sea otters would be allowed (appendix G). The anticipated annual harvest of sea otters under the requested action would be about 1,020 animals for transplants, reintroduction to formally occupied range, scientific research, and controlled harvests by the State.

The State proposes to take sea otters only from population stocks which have occupied all of their former range and are presently at or above OSP, and which are not contributing to the reestablishment of animals in adjacent areas.

The State has estimated that the take of sea otters would be about 1,020 animals annually; the State further maintains that in no event would the take be allowed to exceed 3,000 animals in any 1 year (ADF\&G, 1975). The impacts of these levels of harvest on the two population stocks which are considered to be at or near carrying capacity are given below: 


$\begin{array}{llll} & \begin{array}{l}\text { Percentage of } \\ \text { Population } \\ \text { Ptock }\end{array} & \begin{array}{l}\text { Percentage of } \\ \text { population at }\end{array} & \begin{array}{l}\text { population at } \\ \text { estimate }\end{array} \\ \text { a take of } 1,020 & \text { a take of } 3,000\end{array}$

$\begin{array}{lccr}\text { Rat Islands and } & & & \\ \text { Delarof Islands } & 27,500 & 3.7 & 10.9 \\ \text { Andreanof Islands } & 36,000 & 2.8 & 8.3\end{array}$

The State would conduct these harvests or contract them out while retaining absolute control. Hunting by the public would be prohibited. In addition, the State would retain strict control over the distribution and possession of sea otter pelts. All pelts would be sealed and accounted for individually. The only way an individual could possess a sea otter pelt would be to purchase one legally sold by the State. ADF\&G (1975) estimated that under the management plan all populations would either be maintained at high levels approaching their maximum or would continue to increase with subsequent range expansion.

The ALJ (1977, p. 90) recommended that the extent of the waiver of the moratorium be limited to no more than 3,000 animals and that the harvest be distributed among the subpopulations at the Rat, Delarof, and Andreanof Islands.

Northern (Steller) Sea Lion (Eumetopias jubatus)

An estimated 6,500 sea lions are taken annually from the Alaskan population incidental to commercial fishing operations. About 2,380 of these are taken by domestic fishermen and an estimated 4,125 by the foreign high seas fisheries, of which an estimated 1,152 are killed. These takings will probably continue.

The State anticipated the commercial take for the determinable future at a level of about 6,000 sea lions annually. Prior to the Act, harvests of this magnitude 
had been sustained for several years with the population remaining stable at a high level (ADF\&G, 1973a). Under the proposed action, a limit of 15,000 animals for all purposes would be set. This would be approximately 7 percent of the estimated population of 214,000 .

Under the proposed State regulations, the commercial taking of sea lions would be allowed only under conditions of a permit issued by the Commissioner. Under a State permit system for commercial harvests, the State Fish and Game authorities would control, as needed, who will do the taking, when and where such taking will occur, and how many of the species are to be taken, thus protecting the population stock of sea lions from overexploitation. ADF\&G (1975) estimated that its management program would maintain maximum population levels throughout most of the species' range but would decrease the population in some parts of southeastern, south-central, and southwestern Alaska. The anticipated decreases in population are not expected to affect the sea lion stock adversely. The ALJ (1977, p. 95) recommended limiting the extent of the waiver to 7,800 animals, less 1,152 taken incidentally during foreign fishing operations, except that 2 pups may safely be taken in lieu of 1 adult. Therefore, under the ALJ's recommendation, up to 6,648 adult sea lions could be taken from the population. If the harvest is restricted to pups, as in the past, this would permit the taking of up to 13,296 pups.

\section{Pacific Walrus (Odobenus rosmarus)}

The pre-Act harvest of walrus by Alaskan Natives and others and the take allowed for scientific research and public display approximated 1,670 retrieved animals

a year. Since the imposition of the moratorium, Native take has increased. Under State management, returned in 1976, a quota of 3,000 animals per year has been 
imposed; it is, however, the State's intent to limit the total retrieved annual take to 2,300. The State program would allow a sport harvest which is expected to be about 50 animals per year. These would be taken from a population estimated at 170,000 (Burns, testimony, 1975). The probable retrieved harvest by Alaska-based hunters amounts to 1.0 percent of the estimated population, although the sport harvest alone would only take approximately 0.02 percent of the population. The combined retrieved harvest by Soviet and Alaska Natives is an estimated 3,018 animals or 1.77 percent of the population. Harvests of this magnitude and greater have prevailed during the past two decades, during which time the walrus herds have increased markedly (Burns, testimony, 1975; Fay, testimony, 1975). Total kill in Alaska only, which includes retrieved harvest plus estimated hunting loss, would amount to 3.55 percent of the population and is not expected to have an adverse impact on the population (Burns, testimony, 1975).

In those areas of Alaska where walruses are not an important source of food to local inhabitants, prior to 1972 they have been accorded protection from hunting. Under the waiver implemented on April 5, 1976 (41 F.R. 14372), State regulations have allowed any licensed resident of the State who is dependent on walruses for food to take up to five adult cows or subadults of either sex and an unlimited number of adult bulls each year. In addition, orphaned calves could be taken for food without contributing to the bag limit. Any other licensed hunter with a valid permit is allowed one adult bull per year. Revised hunting regulations, approved by the Director of FWS on May 20, 1977 (42 F.R. 25924), established more restrictive quotas which will be monitored by State enforcement agents, by specific geographic areas within the most heavily hunted game management units. The ALJ (1977, p. 92) recommended that the waiver implemented on April 5,1976, be continued. 


\section{Harbor Seal (Phoca vitulina richardii)}

Alaskan Natives are presently taking approximately 500 land-breeding harbor seals under the Native exemption section of the Act. In addition, about 178 animals are taken annually under scientific research and public display permits. The United Fishermen's Association estimates that up to 2,880 harbor seals would be taken incidental to fishing operations with an unknown number of mortalities.

Under the proposed waiver, the maximum total annual take for all purposes would be limited to 14,000 . This would amount to 5.2 percent of the Alaska population estimated at more than 270,000 animals. Pitcher (testimony, 1976) considered an annual take of 8 percent to be a conservative estimate of the number of animals that could be safely harvested without reducing the population; however, the Marine Mammal Commission (testimony, 1976) recommended a more conservative take of 4 percent as the maximum allowable harvest until sufficient information is obtained to adequately evaluate harvest limits. Proposed State regulations would allow for a general open season with no bag limit. The State believes that an additional 5,822 animals could be taken annually by a regulated commercial harvest. Because the Alaskan population of harbor seals had been increasing despite pre-1972 annual harvests of 10,000 to 60,000 animals, ADF\&G anticipated no adverse impact on the harbor seal population at the proposed harvest level (ADF\&G, 1973a).

Recent information indicates, however, that two areas of the State, the Kodiak Archipelago and the Kenai coast, may have depressed populations (Pitcher, testimony, 1976). Therefore, under the proposed action the commercial harvest would be restricted to areas 4 and 5 , and no single unit would be subjected to a greater than 5 percent harvest level. The State proposes that approximately one-fourth of the proposed commercial harvest will be pups taken before the 
period of highest natural mortality.

The ALJ (1977, p. 106) recommended that the total harvest of harbor seals, including incidental take, should not exceed 8,461 animals. The ALJ also stipulated that in those areas where pups are to be harvested, that two pups could be taken in lieu of one adult. In the recent past, the harbor seal harvest has averaged 10,000 animals-about one-third of which have been pups. A similar harvest, with the same proportion of pups, would be consistent with the ALJ's recommendation.

\section{Largha Sea1 (Phoca vitulina largha)}

The population level is believed to be high and stable (ADF\&G, 1973a) and well above the level of maximum productivity (Burns, testimony, 1976). An estimated historical annual take from the Bering-Chukchi Seas of 2,800 (1.1 percent) by Alaskan Natives would be continued with no anticipated adverse impact on the population level of 250,000. About 3,000 to 4,000 ice-breeding harbor seals are harvested annually by the Soviets (Burns, testimony, 1976), of which 1,000 to 1,500 are estimated to come from the Alaskan stock. The take under the proposed waiver would be limited to 15,000 animals, which constitutes 7.2 to 7.6 percent of the population. Chapman (testimony, 1976) believed that the harvest level proposed is not supported by the available evidence and, therefore, a more appropriate and conservative take of 7,000 animals ( 3.5 percent) for both the Soviets and the United States should be established. The State (ADF\&G, 1975) believed that a take as high as 8-10 percent would allow the population to remain at a high level.

The ALJ (1977, p. 109) recommended that the waiver should not exceed 5,700 animals or 3.5 percent of the minimum estimate of the population. This, he contended, would satisfy the required subsistence needs for approximately 
2,800 animals per year and still remain within OSP.

Since hunting of spotted seals is effectively controlled by regional climatic conditions and seasonal availability of seals, the ADF\&G (1973a) saw no need to propose bag limits for this species at this time.

\section{Ringed Seal (Pusa hispida)}

of all species of ice-breeding seals, the ringed seal is the one subject to the heaviest harvesting pressure. Almost totally a subsistence species, an estimated 10,522 animals are taken annually from an estimated population of 250,000 landfast sea-ice animals--part of a total Arctic population of between 1 million and 1.5 million animals.

Under the proposed waiver, the harvest would be restricted to subsistence users and would be 1 imited to 20,000 animals. Because the population level is estimated to be high and stable, (ADF\&G, 1973a), a take of the level proposed--8 percent of the landfast group or 2 percent of the total--is below a level which would safely maintain the stocks within the range of oSP (ALJ, 1977, p. 112).

Alaska's regulations would permit the taking of ringed seals without bag limit or personal restrictions north of Bristol Bay as hunting would be effectively controlled by regional climatic conditions and seasonal availability of seals (ADF\&G, 1973a).

\section{Ribbon Seal (Histriophoca fasciata)}

Ribbon seals are taken in small numbers in Alaska. The average annual removal by U.S. nationals is estimated to be less than 272 . The estimate of the population is 100,000 animals. The table below shows the relative percentage of the U.S., Soviet, and total harvest: 

U.S. (1966-72)
250
0.25

Soviet (1969-72)

3,115

3.1

Tota1

3,365

3.4

The average annual harvest of 250 animals by U,S. Natives represents 0.25 percent of the population. As a conservation measure, the Soviet harvest has been reduced from a 1962-67 average of 13,550 animals to a 1969-72 average of 3,115 ribbon seals. The harvesting of this species in Alaska has been almost entirely by Native subsistence hunters and would continue under the proposed waiver. The waiver would limit the take to 500 animals annually, which is 0.5 percent of the population estimated to number 100,000 . The total permissible U.S. take, combined with the Soviet take, would constitute 3.6 percent of the population. These levels of take, would have no adverse impact on the population.

State regulations would allow hunting of ribbon seals along the coast north of the north shore of Bristol Bay with no restrictions of season or bag limit. Hunting would actually be controlled by regional climatic conditions and seasonal availability of seals. At most coastal locations these seals are available mainly during spring and fall migrations (ADF\&G, 1973a).

The ALJ (1977, p. 115) found that the proposed waiver allowing a take of 500 ribbon seals annually will have no adverse impact on the population and will maintain OSP.

\section{Bearded Sea1 (Erignathus barbatus)}

An estimated 1,524 bearded seals are harvested by U.S. nationals from a population estimated to be 300,000 animals (ADF\&G, 1973a). The U.S., Soviet, 
and total harvest are shown below as percentages of both the U.S, and Soviet estimates of population.

\section{Percent of Population}

Harvest

$$
\text { U.S. estimate }
$$

300,000

0.5

0.5

1.0
Soviet estimate

450,000

0.33

Soviet $(1964-72) \quad 1,428$

2,928

0.65

This level of harvest has been sustained for many years with no detectable change in the population. Native hunting accounted for almost all of the Alaska harvest and probably would continue regardless of the action taken on the proposal. Under the proposed waiver, the harvest would be limited to 9,000 animals, which includes both retrieved and non-retrieved take. A take of this level, which is 3 percent of the population, would maintain the population above OSP (Burns, testimony, 1976).

The ALJ (1977, p. 119) was uncertain whether take levels proposed by NMFS include both retrieved and unretrieved take. He determined that if the retrieval rate is 1 in 3, then 6,000 animals could be brought ashore as take. As the Soviets take 2,000 animals, 4,000 should be the maximum U.S. harvest returned to shore which represents a total of 12,000 animals when unretrieved take is included.

State regulations would allow the subsistence taking of bearded seals without limit or season along the coast north of the north shore of Bristol Bay. Hunting would be controlled by regional climatic conditions and seasonal availability of seals-mainly during their spring and fall migrations and during the summer months in northern Alaska. These conditions have generally 
acted to limit the annual harvest to usually less than 3,000 animals, entirely or almost entirely by Natives (ADF\&G, 1973a).

Beluga Whale (Delphinapterus leucas)

The population of beluga whales in Alaska occurs in two population stocks (Cook Inlet and Bristol Bay-Bering Sea) and is estimated to be 10,000 (Brooks, 1957; Burns, unpublished notes) to 16,000 animals (ADF\&G, 1975). The anticipated annual take, almost all of which would come from the Bristol Bayn Bering Sea stock and would be taken mostly for subsistence purposes, would be about 180 animals. This would represent $1.1-1.8$ percent of the total population. It is the proposed policy of the State that in no event should the take be allowed to exceed 520 animals (ADF\&G, 1975). This would represent 3.2-5.2 percent of the total population. However, on the basis of the lower population estimate, NMFS proposes to limit the waiver to 360 animals. This would represent 2.2-3.6 percent of the total population. Harvests exceeding these numbers have been taken for many years with no measurable impact on the stocks (ADF\&G, 1973a), and the State of Alaska estimated that the management program would maintain a maximum population level of the Cook Inlet stock and a high population level of the Bristol Bay-Bering Sea stock (ADF\&G, 1975).

The ALJ (1977, p. 99) found that an annual take of 350 beluga whales from the Bering Sea population and 10 from Cook Inlet stock woüld not have any adverse impact on these populations and will maintain OSP.

\section{Socioeconomic Impacts.}

The Marine Mammal Protection Act, with certain exceptions, restricts the taking of marine mammals to Alaskan Natives. The requested action, if implemented would allow all citizens to take certain marine mammalsmexcept sea ottersn- 
under prescribed regulations. NonmNatives who would participate in such taking may consider such action as favorable.

When the Act was passed in October 1972, it appeared that up to 50,000 Eskimos, Aleuts, and Indians in Alaska would receive a windfall because the Act allowed these groups to harvest marine mammals for subsistence, barter, and handicraft usage but restricted any takings by non-Natives. The immediate effect, however, was to depress the economy in some Native regions, especially north of Bristol Bay. The Act also created a severe economic stress for some commercial hunters and traders. Passage of the Act eliminated the opportunity for nonNatives to harvest or for non-Natives and Natives alike to sell raw skins, which halted the supply for European market outlets that formerly bought 8,000 to 10,000 seal skins and 4,000 to 6,000 sea lion hides (Burns, 1973). . $^{\text {I }}$

In its present form, the Act allows an unlimited harvest for subsistence and Native processing of handicraft articles. Seals are the primary resource base for the economy in many Eskimo regions. The meat serves as a food staple, and the hides are sewn into various articles of clothing or are bartered. Formerly the raw skins were sold for the outside market. In some Eskimo villages, it is estimated that income derived from the sale of raw seal skins constituted as much as 10 to 15 percent of their annual earned income.?

It may be argued that furs or skins tanned and manufactured into Native handicrafts would bolster the regional economy because of the value added to the original product. Apparently this has not been the case in the short run, because commercially tanned furs are a much superior raw material for Native

7/ This section is based on an analysis prepared by the Regional Economist, Alask a Region, NMFS. 
handicrafts, and there were no provisions in the original regulations for local agents to ship hides to outside tanneries or for commercial tanneries to process hides. Thus two important segments, transportation and processing were virtually eliminated from the economy. The effect of this is apparent in the fact that only 6,000 seals (icembreeding) were harvested in 1973, which was 62 percent below the 1968-72 annual average of 14,300 ice seals (R.A. Rausch, oral communication, 1975).

Assuming a strong demand for Native products crafted from marine mamal fur, skins, or hides, the market could greatly strengthen in the future. Five tanneries have been certified by the NMFS to tan marine mammal hides harvested by Natives, and a system of establishing agents to ship hides for tanning has been initiated. An Anchorage entrepreneur has taken advantage of the general definition of Native handicraft and is now manufacturing garments of fur or hide utilizing Alaska Native labor, labelled "native handicraft". Thus a manufacturing monopoly may have been established. This situation could benefit the Alaska Native people but could also be detrimental to the resource, because the Alaska Natives are essentially allowed an unlimited harvest of marine mammals for subsistence or handicraft use. Also, monopolistic control may be a detriment to the consumer.

A 1958 study of the Point Hope economy revealed that 20 percent of the annual village gross income was derived from the sale of the products and services associated with marine mammals (James Omnik, unpublished manuscript). How much of this income was derived from the sale of raw furs and ivory is not known, but this figure would vary from year to year depending upon the world demand for fur products. Seal hide (raw and tanned) prices have fluctuated from $\$ 8.00$ to $\$ 40.00$ per pelt over the last 5 years. If seal hide prices were 
assigned the average value of $\$ 16.00$ per adult pelt for all species, a potential income of $\$ 112,000$ was lost to the Alaska Native population in 1973. It is not known at this time what the total cutback in production of Native handicrafts will be for $1973-74$, but this amount is probably significant in the larger communities of Bethe1, Kotzebue, Teller, and Barrow.

Other cash sources of income have been greatly reduced. Sale of a polar bear hide, for instance, had once brought $\$ 3,000$ to $\$ 5,000$ to the successful nonNative hunter. A guided polar bear hunt earned at least half as much. An estimated total loss of income derived from polar bear hunting is above $\$ 150,000$.

In summary, it is estimated that the Alaska Native economy lost more than $\$ 250,000$ in revenue in 1973. This is a significant loss of income for a coastal population of approximately 50,000 individuals, considering that more than 60 percent of the families residing in the northern Arctic regions exist on an income less than the $\$ 3,870 \underline{8} /$ level defining poverty in the "lower 48 " (Rogers, 1973). A family earning $\$ 2,000$ to $\$ 3,000$, annually that loses the opportunity to earn an additional $\$ 500.00$ is severely affected. Such a family may lose the opportunity for a down payment on a snow machine or to purchase gasoline, additional sled dogs, or other commodities. Seasonal employment is available outside the region, and welfare aid is also available, but labor mobility is not always the desirable answer and increasing dependency on welfare payment is the most repugnant (to the Native) alternative of all.

\section{Other Impacts.}

In this section, we examine whether or not the promulgation of Federai regulations, waiving the moratorium, and transferring management to the State 8/ Farm family of four, Department of Labor, 1974. Non-farm family of four, $\$ 4,550$. 
would affect certain activities under which takings occur, pursuant to the Act. They also include activities which we have determined to be outside the Act but which, nevertheless, affect marine mammals in waters off Alaska. These activities, under which current or potential takings have been identified in previous sections, are shown in table 8 with an indication of the probable impact of the requested action--Federal regulations and State management.

\section{Table 8.--Impact of requested action, if implemented, on activities discussed in this report}

Activity

Scientific research

Public display

Sport and commercial hunting

Subsistence hunting

Domestic fishing operations
Probable results of State management

a. State would continue full-scale research.

b. Non-Alaskan researchers would continue to obtain Federal permits under a joint State-Federal permit program.

a. No change anticipated at present leve1 of requests, which will continue under Federal Government administration.

a. Waiver will permit resumption of sport and commercial harvesting of marine mammals.

b. State to regulate harvest subject to quotas imposed and as long as populations remain within the range of OSP.

a. Some restrictions in take such as limits on polar bear and walrus.

b. Removal of some restrictions on sale of skins.

a. No change anticipated under Federal Government administration.

E. THE POTENTIAL IMPACT OF SPECIFIC STATE REGULATIONS

The State of Alaska has provided historical data on harvests and anticipated levels of future harvests. Comparing these harvest levels to population or stock size is a relatively direct 
means of assessing impact on populations. Examination of proposed marine mammal regulations of the State (appendix G) provides a means of determining how the State agency intends to reach the specific harvest levels and how the population will be protected against overharvest. The Alaska State Constitution requires that all replenishable resources within the State be managed on the "sustained yield" principle. Several comments at the public hearings questioned whether "sustained yield" management by the State could be compatible with the MMPA concept of OSP. Two points are worth making here: (1) If there is a waiver and return of management to Alaska, Federal ceilings will be set on the annual kill for each stock which will be allowable under the waiver with the objective of maintaining OSP. The Federal authorization for the State to manage the resource in such an instance will be conditional upon whether Alaska can control the harvest within the Federal ceilings. If the limits are exceeded, the Federal Government can resume control and reimpose complete protection. (2) The ADF\&G's chief spokemen at the hearings, John Burns and Game Director Robert Rausch, emphasized that OSP requirements could be accommodated under the State Constitution. This is because the State views "sustained yield" as a flexible standard, depending on the context. While sustained yield in terms of consumption may be stressed in the case of animals important for human sustenance, other populations like sea otter stocks may be managed with an eye to sustained yield of recreational opportunity or esthetic quality.

In the following sections, we will examine specific regulations of the State which would appear to have a potential impact on the species populations. These are: methods and means, special permits, season and bag limits, and humane means of taking. 
1. Regulation on Native Take

The Constitution and State laws of Alaska prescribe equal treatment to Natives and non-Natives. However, the ADF\&G has recognized the historical need of Alaska Natives for a subsistence harvest just as the Act has done. Therefore, many regulations have been drawn in a manner that allows Natives and a small number of non-Natives a subsistence take but generally precludes non-Natives from capitalizing on these regulations. In southeast Alaska, where non-Natives predominate, there are some open seasons on seals and sea lions, but bag limits are small, thereby allowing some subsistence taking but precluding large-scale commercial taking which must be done by special permit. Along the northern coast, where relatively few non-Natives live, there are year-round open seasons on seals with no bag limit. Because the ice seals tend to be available in quantity during the severest weather, only local residents are able to harvest. In less severe weather, the ice seals are either absent or present in small numbers and scattered, again precluding a commercial take.

The regulations on the two marine mammal species with sport hunting potential are geared to the benefit of Natives in a different way. Regulations on walrus and polar bear allow residents to take a small number for food but under restricted conditions. The effect again is to allow Natives to harvest for subsistence and to limit sport hunting to one animal per year per hunter. 
In this manner, the regulations refer to residents as required by the State Constitution and laws, but geographical and seasonal climatic considerations separate Natives from non-Natives in their ability to take under the regulations.

\section{State of Alaska Commercial Taking Permit Requirements}

It is anticipated that commercial taking requests will be considered only for sea lions and harbor seals in areas 4 and 5 . Anyone wishing to harvest these species commercially must specify the following facts in writing: (1) numbers that they wish to harvest; (2) the specific location where they will be taken; (3) the manner in which they will be taken; (4) the period during which they will be taken; (5) the name, number, and registry of the vessel that will be used; and (6) any additional information that the Commissioner deems appropriate.

Sea otters, if harvested at a11, will be taken by the State only. Before any sea otters are harvested, the Commissioner will first consider whether or not it would be more desirable to transplant a number of them to a location not then inhabited by the species but one that was previously so inhabited. All harvests will be restricted to those populations that have completely recovered from the exploitation which occurred prior to 1911 , that are within the range of OSP, that are experiencing high rates of natural mortality and low recruitment rates, and that are not contributing to the repopulation of adjacent areas.

3. Alaska Marine Mammal Seasons and Bag Limits.

There are two general ways to control the numbers of animals to be taken: 
(a) quotas and (b) seasons and bag limits. The State has estimated

the future take under State management and has set an upper limit or quota for each species. The ALJ (1977) has recommended that some of these quotas be reduced (e.g., polar bear).

Seasons and bag limits are used to provide the regulatory protection, in addition to such natural regulatory mechanisms as geographical remoteness, seasonal availability, and, sometimes, the dispersion of the animals.

\section{Humane Taking Provisions}

The proposed regulations of the State of Alaska contain humane safeguards through prohibition of certain methods of taking. For marine mammals, the only legal means for taking are:

(1) with a hand-held rifle using a centerfire cartridge, except rifles capable of fully automatic fire;

(2) with the aid of spears and harpoons that are hand held or thrown;

(3) with the aid or use of surface transportation only;

(4) with the aid of unleashed or unharnessed dogs, for polar bear only; * and

(5) with nets, shotguns, and weapons using rimfire cartridges, or clubs, only as specifically authorized by permit.

Under the proposed State regulations, the following methods would be specifically

\footnotetext{
* The ALJ, however, recommended-(1977, p. 136) that dogs not be used to hunt polar bears. Also, revised State regulations, approved on October 13, 1976 (41 F.R. 44875), restrict hunting of walrus to rifles of caliber $.264(6.5 \mathrm{~mm})$ or larger (except 30-30 caliber).
} 
(1) the use of poison;

(2) the use of helicopters or rotorcraft in any manner;

(3) the use of a motorized vehicle for the purpose of driving, herding, or molesting marine mammals;

(4) the use of a machinegun or set gun;

(5) the aid of fire, explosives, bombs, smoke, or chemicals;

(6) sea otter may not be taken by use of a dog, trap, snare, net, or fish trap;

(7) aircraft may not be used in any manner for taking polar bear; and

(8) polar bear may not be taken by use of traps, snares, or barbed arrows. 
The proposed Federal action is to waive the moratorium and transfer management authority for the requested nine species (polar bears, sea oiters, sea lions, walrus, harbor and spotted seals, ribbon seals, ringed seals, bearded seals, and beluga whales) to the State within waters off its coasts and to establish a cooperative management program between the State and the Federal Government in waters beyond 3 miles.

The alternatives to the proposed actions are as follows:

(A) Continue the moratorium and retain management authority under the Federal Government (no action);

(B) Continue the moratorium and transfer management authority to the State of Alaska;

(C) Waive the moratorium and retain management authority under the Federa1 Government;

(D) Waive the moratorium and transfer management authority of only selected species to the State of Alaska; and

(E) Waive the moratorium to a greater or lesser extent than proposed for each species.

These alternatives and the consequences of each are discussed below and are compared to the proposed action.

A. CONTINUE THE MORATORIUM AND RETAIN MANAGEMENT AUTHORITY UNDER FEDERAL GOVERNMENT (NO ACTION)

1. Biological consequences:

(a) An unharvested population stock is capable of reaching the optimum carrying capacity of its habitat and even surpassing 
it. This is especially true for those species that feed on fish or crustaceans subject to strong harvesting pressures.

Continuing the moratorium will allow population stocks to regulate their own numbers by unmanaged fluctuations. Maximum productivity may not be achievable under this management alternative.

Kenyon (1969) detailed the effects of severe fluctuations and a population crash of sea otters at Amchitka Island. When the era of sea otter exploitation ceased in 1911, only about 100 otters remained at Amchitka Island. Under total protection, the population increased to an estimated 4,000 animals by 1940 . By 1949, the population had over-utilized its available food supply and declined to less than one-third of its 1940-43 maximum. It now fluctuates annually near a population level about one-half of the maximum.

Evidence, given previously, indicates that the sea lion and beluga populations in most of their Alaskan range have reached the carrying capacity of their habitat. Harbor seals are reported to be more numerous in most of their range than they have been for several years (ADF\&G, 1973a). The ice seals are at or near maximum population levels and stable, and polar bears appear to be approaching maximum (ADF\&G, 1975) .

(b) Indians, Aleuts, and Eskimos would continue to harvest marine mammals without restrictions other than those imposed by section 101 of the Act. Unless populations or population stocks are found to have been depleted, polar bear sows and cubs will 
continue to be legally taken, and sea otters, sea lions, seals, and beluga whales could be harvested without restriction. The Act also allows subsistence hunting in areas that have previously been restricted or closed.

\section{Socioeconomic consequences:}

(a) Commercial and sport harvest of various species of marine mammals in Alaska would not be resumed. The economic benefits of the harvest of polar bears, sea otters, sea lions, and seals would be lost to the Alaskan resident guides and to the processors and retailers of the marketable products from these animals. Natives might continue to waste parts of marine mammals of no use to themselves or other Natives because they cannot sell unprocessed marine mammal parts except to other Natives. Jobs and income from retailing marine mammal products and parts nationwide for other than Native handicraft uses would be lost if the moratorium is continued.

(b) Conflicts and competition between fishermen and certain stocks of marine mammals, such as sea lions and some seals, will continue and probably increase as marine mammal stocks increase under a moratorium. The marine mammal populations are large, and the majority of the involvements are the result of direct and sometimes intense competition between fishermen and marine mammals for the available stocks of fish, sometimes resulting in gear damage or loss to the fishermen and mortality to marine mammals. 


\section{Administrative consequences:}

(a) Maintaining that it has no management authority and therefore no need for the information, the State of Alaska would probably drastically reduce or eliminate all research and monitoring of marine mammal populations.

(b) Federal agencies would require increased staffing and funding to adequately manage and monitor the status of the population stocks.

(c) Information on stocks of marine mammals will continue to be unavailable or will be reduced. Data collection from harvested animals has been reduced with the moratorium, and permits for scientific research have not included taking on as large a scale as harvests. Examination of large numbers of specimens is necessary for the study of certain aspects of population monitoring, such as reproductive history and biology, food habits, and incidence of disease.

B. CONTINUE THE MORATORIUM AND TRANSFER MANAGEMENT AUTHORITY TO THE STATE OF ALASKA.

1. Biological consequences:

(a) If a population stock is not managed but is allowed to increase as rapidly and as far as it can, it may reach a level that is beyond the optimum carrying capacity of its habitat. This is especially true of those species that feed on fish or crustaceans subject to strong population pressures by harvesting.

(b) Indians, Aleuts, and Eskimos would continue to harvest marine mammals without restrictions except those imposed by the Act. 


\section{Socioeconomic consequences:}

(a) Commercial and sport harvest of various species of marine mammals in Alaska by non-Natives would not be resumed. The economic benefits of the harvest of polar bears, sea otters, sea lions, and seals would be lost for the non-Native hunters, guides, and processors and retailers of the marketable products from these animals. Natives will continue to waste parts of marine mammals of no use to themselves or to other Natives because they cannot sell raw parts of marine mammals except to other Natives.

(b) Conflicts between fishermen and certain stocks of marine mammals, such as sea lions, will continue and probably increase as marine mammal population stocks increase under a moratorium.

\section{Administrative consequences:}

(a) The State has indicated an unwillingness to accept "management" responsibility if its role will simply be to enforce the moratorium. Even if the State were to accept such a return, its enforcement can be expected to be less than enthusiastic and would not really alter the present status quo. The State without a return of management, shares enforcement responsibility with the Federal agencies in carrying out the moratorium.

(b) Information on stocks of marine mammals will be reduced. Data collections from harvested animals has been reduced with the moratorium and permits for scientific research have not included taking on as large a scale as harvests. Examination of large numbers of speciments as necessary for study of certain aspects of population monitoring, such as reproductive history and biology, food habits, and incidence of disease. 


\section{Other consequences:}

(a) This action would benefit individuals and groups that oppose the taking of any marine mammal as an unwise use of this resource.

C. WAIVE THE MORATORIUM AND RETAIN MANAGEMENT AUTHORITY UNDER THE FEDERAL GOVERNMENT

1. Biological consequences:

(a) Regulated harvesting of selected marine mammal species by nonNatives could be allowed. This action could result in a managed level of population stocks, which could assist in holding the population levels within the carrying capacity of the habitat, taking into account changes in the ecosystem; such a managed level of population stocks would be similar to the proposed action.

(b) The Native exemption section of the Act would still be in effect, allowing the largely unrestricted taking of seals, sea 1ions, and belugas. The take of polar bear sows and cubs would continue, and sea otters could be taken for subsistence and cottage industries.

2. Socioeconomic consequences:

(a) Allowing non-Natives to participate in the harvest of selected species of marine mammals would result in an economic gain to guides, processors, and retailers of the marketable products from these animals. 
(b) The Native exemption section of the Act (sections 101(b)(1), (2) and (3)) now restricts the market that the Natives have for the parts of marine mammals of no use to themselves or to other Natives. Native take for other than subsistence and handicraft purposes would be regulated by the Federal Government instead of the State as in the proposed action.

(c) Conflicts between fishermen and certain stocks of marine mammals, such as sea lions, could be decreased by a regulated harvest, resulting in an economic benefit to the fishermen.

\section{Administrative consequences:}

(a) Federal agencies would require increased staffing and funding to adequately manage and monitor the status of the population stocks.

(b) The State of Alaska would probably drastically reduce or eliminate its research efforts, having no management needs for that information.

(c) Information on stocks of marine mammals would be increased by the availability of large collections of biological specimens from the increased harvest.

D. WAIVE THE MORATORIUM AND TRANSFER MANAGEMENT OF ONLY SELECTED SPECIES TO THE STATE OF ALASKA

The consequences of withholding one or more of the nine requested species from State management could only be discussed on a species-by-species basis. The consequences detailed under alternative (C) would be applicable to the species withheld. 
E. WAIVE THE MORATORIUM TO A GREATER OR LESSER EXTENT THAN PROPOSED ON EACH SPECIES

\section{Biological consequences:}

The proposed action to waive the moratorium is limited on each species because of the need for a determination that populations are at or above optimum sustainable population levels and that the waiver will allow maintenance of optimum sustainable populations.

A final determination to waive to a greater or lesser extent will be based upon the hearing record. If a population could not be determined to be within the range of OSP, then a waiver might be limited in extent until such time as that species is determined to be within the range of OSP in that, area.

If the extent of the waiver is reduced on certain species, the impacts are expected to be the same as those of the proposed action. Populations would most likely be maintained at levels above the lower range of optimum sustainable populations. There is a possibility that maximum productivity would not occur at higher population levels. If the extent of the waiver was greater than proposed on individual species, the ability of the populations to maintain optimum sustainable levels must be determined. The depth and precision of scientific knowledge available upon which to base OSP is not adequate to make precise determinations. Until such time as better data are available and OSP can be better defined, conservative limits on the waiver seem justified.

The impact of a waiver greater than that proposed cannot be accurately 
gauged with available information. In particular, it cannot be determined that OSP would be maintained or that the health and stability of the ecosystem would be unimpaired.

\section{Socioeconomic consequences:}

Impacts different than those discussed for the proposed action cannot be identified at this time.

\section{Administrative consequences:}

The administrative consequences of waiving to a greater or lesser degree is expected to be the same as those of the proposed action.

\section{THE PROPOSED ACTION}

The proposed action, consequences of it, and method of implementing, are outlined below for comparison with the above alternatives.

A. WAIVE THE MORATORIUM, TRANSFER MANAGEMENT TO THE STATE WITHIN WATERS

UNDER ITS JURISDICTION, AND JOINT FEDERAL-STATE MANAGEMENT IN WATERS BEYOND 3 MILES (PROPOSED ACTION)

1. Biologica1 consequences:

(a) Regulated harvesting of selected species of marine mammals for sport and commercial purposes would result in a managed level of population stocks and could assist in holding population levels within the carrying capacity of the habitat, taking into account changes in the ecosystem.

\section{Socioeconomic consequences:}

(a) Natives would no longer be required to convert all parts of marine mammals into authentic articles of Native handicraft or clothing before sale of them to non-Natives. 
Their market for such items as seal skins and polar bear hides would be greatly expanded, resulting in an increase in economic returns from such items.

(b) Commercial and sport harvest of various species of marine mammals could be resumed, resulting in an economic benefit to both Native and non-Native guides and to processors and retailers of the marketable products of those marine mammals.

(c) Conflicts between fishermen and certain stocks of marine mammals, such as sea lions, could be reduced by regulated harvest, resulting in an economic benefit to the fishermen.

\section{Administrative consequences:}

(a) The State could exercise authority over all its citizens, Native and non-Native alike.

(b) The administrative burden on the State would be increased; however, Alaska had an active management and research program on polar bears, sea otters, sea lions, walruses, seals, and beluga whales since 1959, and it has the trained personnel and existing organizational structure to adequately carry out this responsibility within its jurisdiction.

(c) Information on stocks of marine mammals would be increased by the availability of larger collections of biological specimens from the allowable increased harvest.

(d) Section 109(a)(2) of the Act allows a State, under certain circumstances and conditions, to adopt laws and regulations relating to the protection and taking of marine mammals only 
within its jurisdiction. Since the animals under consideration inhabit the marine environment that extends beyond the territorial jurisdiction of the State, a cooperative management program between the State and the Federal Governments would provide for consistent management practices to be exercised over the various populations in their entire range.

The Administrative burden would be split, with the State under a Federal/State management program.

\section{UNAVOIDABLE ADVERSE ENVIRONMENTAL IMPACTS}

No unavoidable adverse environmental impact on marine mammal populations would be anticipated from the proposed action of the waiver of the moratorium and subsequent resumption of management authority by the State of Alaska. The management program proposed by the State is designed to maintain the species populations within their ranges of OSP, thus insuring that they will remain a significant functioning element of the ecosystem.

\section{RELATIONSHIP BETWEEN SHORT-TERM USE OF THE ENVIRONMENT AND}

\section{MAINTENANCE AND ENHANCEMENT OF LONG-TERM PRODUCTIVITY}

The short-term use of the resource by regulated taking of marine mammals, within the range of their optimum sustainable populations, would have no effect upon the long-term productivity of the environment. Some insight into this relationship can be gained by reviewing exploitations of three species of marine mammals in Alaska, exploitations wholly unregulated and at a rate exceeding that which would be allowed under any action consistent with the Act. The sea otter, walrus, and fur seal populations were at one time exploited at levels beyond which the population could be maintained at relatively high levels. 
The populations of all three species were drastically reduced. When harvesting ceased (sea otters) or was closely regulated (walruses and fur seals), all three species responded by a rapid increase in population levels. The question of long-term effects on the environment can only be partially answered. The observed fact is that the environment maintained its capacity to support these species at relatively high levels.

Long-term productivity of a species population is (or may be) enhanced by a regulated taking which maintains a population leve1 at its optimum sus:ainable population, a level that is assured to be at or above maximum productivity and at which the population or population stocks of the species will continue to be a significant functioning element of the ecosystem and one that the habitat can support. If a marine mammal population is allowed to increase as rapidly and as far as it can, it may reach a level that is beyond the carrying capacity of its habitat. Kenyon (1969) examined the effect of a population decline of sea otters at Amchitka Island, Alaska, and measured the present carrying capacity of that habitat as about one-half of its original. The effects of such over-utilization of its habitat by a species of marine mammal involves a complex chain of events and consequences which have received little investigation and are therefore poorly understood. Insight into the effects of over-utilization on the productivity of the environment can be gained by studies of sea otter/sea urchin interrelationships. The appearance of large numbers of sea otters in an area may reduce the numbers of mature green sea urchins in waters less than 60 feet deep. In many areas, the extent of kelp beds is restricted by grazing of mature sea urchins (Estes and Palmisano, 1974). Reductions of the numbers of adult sea urchins may permit expansion of kelp beds, which will cause a change in the species composition and distribution of 
the invertebrate population of that environment. Such a change could be of a long-term nature (ADF\&G, 1973b).

Commercially important fish stocks that occupy the same ecosystem as the marine mammals in Alaska are being exploited at a rate which is believed to be above the sustainable level for some fishes that are important to some of the marine mammals (INPFC, 1974). In effect, the carrying capacity of the system may have been reduced for some of the marine mammals. Any such change in the environment could have a long-term effect upon the capability of the environment to support large populations of marine mammals. Allowing the unregulated expansion of a population in the face of a deteriorating environment will only shorten the time before the environment will no longer be capable of supporting large numbers of certain species of marine mammals and will hasten the further reduction of fish stocks.

At some future date, it is reasonable to assume that requirements for protein to feed an increasing human population of the world will cause resource managers (State, Federal, and international) and the public to make difficult decisions as to the extent to which they will allow competition by marine mammals for the increasingly smaller quantities of harvestable fishes. In Table 9, the estimated exploitation rates for fishes by pinnipeds and by fishermen in the eastern Bering Sea and Aleutian areas are compared with estimated stocks of fish. This consumption rate, conservatively estimated, is already more than one-third of the estimated stocks, and the estimated consumption by pinnipeds is nearly one and one-half times greater than that of the U.S. and foreign catch. Thus, to maintain a healthy and stable ecosystem, there may be little room for expansion of fishing and marine mammal stocks simultaneously. 
Table 9 - Consumption of fish and comparison with standing stocks in the eastern Bering Sea and Aleutian areas $1 /$

Thousands of

metric tons

Estimated finfish consumed by fur seals

480

Estimated finfish consumed by other pinnipeds $2 / \quad 2,960$

Estimated finfish consumed by sea birds

Estimated vertebrate predation

$\frac{50}{3,490}$

Estimated 1972 catch of foreign fleets $3 /$

Reported 1972 catch by U.S. fishermen 3/

Estimated total catch

2,250

$\frac{60}{2,310}$

Estimated total catch plus vertebrate predation 5,800

$\begin{array}{ll}\text { Estimated stock of all finfish }{ }^{3 /} & 17,000\end{array}$

Percent standing stock annually taken by

commercial fisheries and pinnipeds (Approximate) 34

Percent taken by pinnipeds (Approximate) 20

Percent taken by commercial fisheries 14

(Approximate)

1/ Adapted from table prepared by Marine Mammal Division, Northwest Fisheries Center, Seattle (see Eable 5, DEIS - Renegotiation of Interim Convention on Conservat..on of North Pacific Fur Seals, NMFS, DOC, January 1975).

2/ Sea lions and hair seals.

3/ INPFC Documents 1680 and 1663, and Pruter, 1973. 
VII. ANY IRREVERSIBLE OR IRRETRIEVABLE COMMITMENTS OF RESOURCES

IN THE PROPOSED ACTION SHOULD IT BE IMPLEMENTED

Implementation of the proposed action, allowing the regulated taking of polar bears, sea otters, sea lions, seals, walruses, and beluga whales under a program based upon principles of renewable resource management, would result in no irreversible or irretrievable commitments of the populations of these animals. 


\section{LITERATURE CITED}

Administrative Law Judge, 1977. Recommended decision in the matter of the request by the State of Alaska to waive the moratorium on nine species of marine mammals and allow the State to resume management. Department of the Interior. $150 \mathrm{p}$.

Alaska Department of Economic Development. 1972. (ADED). Alaska statistical review, 1972. Juneau, Division of Economic Enterprise.

Alaska Department of Fish and Game. 1973(a). Alaska marine mammal regulations, status reports, and management policies. (Appendix G).

Alaska Department of Labor. 1970. (ADL). Alaska Native population, 1970 census. Employment Security Division and Research and Analysis Division. Mimeo; August 1970 .

Alaska Department of Labor. (N.D.). Statistical tables on "Population and Work Force Data by Race, Ethnic Group and Sex--State of Alaska." Mimeo.

Allen, J. A., 1880. History of the North American pinnipeds, a monograph of the walruses, sea lions, sea bears, and seals of North America., U.S. Geological and Geographical Survey, Misc. Pub. No. 12, 785 p.

Alverson, D. L., A. T. Pruter, and L. L. Ronholt, 1964. A study of demersal fishes and fisheries of the northeast Pacific Ocean. H. R. Macmillan Lectures in Fisheries. Vancouver, Univ. of British Columbia, 190 p.

Barabash-Nikiforov, I. I., 1947. Kalan. (The Sea Otter, pp. 1-174) Soviet Ministrov RSFSR. Glavnoe upravlenie po zapovednikam. (In Russian,) 
(Translated from Russian by Dr. A. Birron and Z. S. Cole. Published for the National Science Foundation by the Israel Program for Scientific Translations, Jerusalem, 1962. 227 p., Illus.)

Bartonek, J. C., R. Elsner, and F. H. Fay. 1974. Mammals and birds. In D. W. Hood, Convener Probes: A prospectus on processes and resources of the Bering Sea shelf 1975-85. National Science Foundation, Office of Polar Programs. March 1974.

Bishop, R. H., 1967. Reproduction, age determination, and behavior of the harbor seal, Phoca vitulina, in the Gulf of Alaska, MS thesis. College, Alaska, University of Alaska, $121 \mathrm{p}$.

Bigg, M. A., 1969. The harbor seal in British Columbia. Fish. Res. Bd. Can. Bu11. 172 .

Brooks, J. W., 1957. Beluga investigations in Bristo1 Bay. Annual Report, Alaska Department Fisheries 9:57-58.

Brooks, J. W., 1970. Infra-red scanning for polar bear. Bears - their biology and management IUCN News Series No. 23:138-141.

Burns, J. J., 1973. Alaska marine mamma1 report, v. DIII, Project Progress Report, Federal Aid in Wildlife Restoration, Alaska Department of Fish and Game, Juneau.

Burns, J. J., and S. H. Harbo, Jr., 1972. An aerial census of ringed seals, northern coast of Alaska. Arctic 25:279-290. 
Calkins, D. G., K. W. Pitcher, and K. Schneider. 1975. Distribution and abundance of marine mammals in the Gulf of Alaska. Unpublished report prepared by $A D F \& G$, under contract with U.S. Dept. Comm. NOAA. 39 p.

Dodimead, A. J., Felix Favorite, and T. Hirano. 1962. Review of oceanography of the subarctic Pacific region. In Salmon of the North Pacific Ocean Part II. INPFC Bulletin No. 13. Vancouver, B. C. 195 p.

Dunbar, M. J., 1953. Arctic and subarctic marine ecology, Arctic 6(2):75-90.

Estes, J. A., and J. F. Palmisano, 1974. Sea otters: Their role in structuring nearshore communities. Science 185:1058-1060.

Favorite, Felix, and others. A report to the INPFC on the oceanography of the North Pacific Ocean. (manuscript in preparation).

Fay, F. H., 1957. History and present status of the Pacific walrus population. Trans. No. Amer. Wild1. Conf. 22:431-445.

Fiscus, C. H., and G. A. Baines, 1966. Food and feeding behavior of Steller and California sea lions. J. Mammal. 47:195-200.

FitzGerald, J. H. (chairman), 1968. Alaska Natives and the land. Federal Field Committee for Development and Planning in Alaska (FFCDPA), A report to the United States Senate, Committee on the Interior and Insular Affairs, Government Printing Office, Washington, D.C. 565 p.

Grauvoge1, Car1, 1974. Seal survey-inventory progress report-1973. Game Management Units $17-26--$ coastal waters.

Gulland, J. A., 1971. (Compiler and Editor) and the fish resources of the ocean. FAO, Via della Terme di Caracalla, Rome, Fishing News (Books), Ltd. Surrey, England. 
Heller and Scott (no date). Cited in FFCDPA, 1968.

INPFC. Minutes of the annual meeting, 1974.

Jamison, R. J., 1973. An evaluation of attempts to re-establish the sea otter on the Oregon coast. Unpubl. Prog. Report. Coop. Wild. Res. Unit, OSU, Corvallis, Ore., March, 1973.

Kenyon, K. W., 1960. Aerial survey of walruses in northern Bering Sea, February 23 to March 2, 1960. Bureau of Sport Fisheries and Wildlife, Branch of Wildlife Res., i \& 23 p., 3 charts, 10 figures.

Kenyon, K. W., 1969. The sea otter in the eastern Pacific Ocean. N. Amer. Fauna: 6S, $352 \mathrm{p}$.

Kenyon, K. W., 1972. Pacific walrus, In Alice Seld compiler. Seals, sea lions, walruses in eastern North Pacific and Arctic waters. Seattle, Pacific Search Books p. 32-38.

Kenyon, K. W., and D. W. Rice, 1961. Abundance and distribution of the Steller sea lion. J. Mammal. 42:223-234.

Laughlin, W. S., 1970. Aleutian ecosystems, AAAS Symposium, Dec. 26-27, 1970, Chicago. Science 169:1107-1108.

Laughlin, W. S., and W. G. Reeder, 1962. Revision of Aleutian prehistory. Science $137: 856-857$.

Lentfer, J. W., 1972. Statement on polar bears in relation to House Joint Resolution 1.179 for House Committee on Foreign Affairs. Mimeo.

Lentfer, J. W., 1973. Polar Bear Report. Alaska Dept. of Fish and Game, Juneau, Federal Aid Progress Report, v. 14 p. i-24. 
Lensink, C. J., 1962. The history and status of sea otters in Alaska. Thesis submitted to the Faculty of Purdue University in partial fulfillment of the requirements for the degree of Doctor of Philosophy. Unpublished, copy in Fish and Wildlife Service files. (Cited in Schneider, 1975.)

Marine Mamma1 Division 1974. Marine mammal-food chain relationships in the eastern Bering Sea. National Marine Fisheries Service, Northwest Fisheries Center, Seattle (manuscript).

Markov, S. V., 1965. The present status of the Komandorski population of $\underline{\text { Enhydra }} \underline{\text { lutris }}$ and the prospects for its practical usage. In Pavlovskii, E. N., B. A. Zenkovich, and others (eds.). Marine mammals. p. 212-220. Translated by Nancy McRoy, Apri1 1966. (Cited in Schneider, 1975.)

Mathesin, 0., R. T. Baade, and R. J. Lopp, 1962. Breeding habitats, growth and stomach contents of the Stellar sea 1ion in Alaska. J. Mammal $43: 469-477$

McAllister, D. D., 1969. Aspects of estimating zooplankton production from phytoplankton production. Jour. Fish. Res. Bd. Can. 26:199-220.

McAllister, D. D., 1972. Estimates of the transfer of primary production to secondary production at Ocean Station P. In Takenouti, A. Y., and others. Biological oceanography of the northern North Pacific Ocean. Tokyo, Idemitsu Shoten, $626 \mathrm{p}$.

McRoy, C. P., J. J. Georing, and W. E. Shiels 1972. Studies on primary production in the eastern Bering Sea Takenouti, A. Y., (chief ed.) Biological oceanography of the Northern North Pacific Ocean. Tokyo, Idemitsu Shoten p. 199-216. 
National Marine Fisheries Service, 1972. St. George Island Research Reserve. National Marine Fisheries Service, Seattle, Washington, Sept. 6, 1972. Processed.

National Marine Fisheries Service, 1974. Administration of the Marine Mammal Protection Act of 1972, June 22, 1973 to April 30, 1974. Federal Register, v. 9, No. 122, June 24, 1974, p. 23896-23922.

National Marine Fisheries Service, 1975. DEIS--Renegotiation of Interim Convention on Conservation of North Pacific Fur Sealṣ. DoC. January 1975.

Omnik, J. 1960. Writings on Point Hope, Part 1 Economic Base, Unpublished manuscript. Lawrence, Kansas.

Pruter, A. J., 1973. Development and present status of bottom fish resources in the Bering Sea. J. Fish. Res. Bd. Can. 30(12):2372-2385.

Rice, D. W., and V. B. Scheffer, 1968. A list of the marine mammals of the world. U.S. Fish and Wildlife Service, Spec. Sci. Rept., Fisheries: No. 579 .

Rogers, G., 1973. A study of the social-economic impact of changes in the harvesting labor force on the Alaska salmon fishery. Institute of Social Economic \& Government Research, NMFS, State/Federal Contract 1.36704, University of Alaska, College, Alaska.

Sanger, G. A., 1972a. Fishery potentials and estimated biological productivity of the subarctic Pacific region. In Takenouti, A. Y., and others. Biological oceanography of the northern Pacific Ocean. Tokyo, Idemitsu Shoten. p. 589-611. 
Thorsteinson, F. V., R. W. Nelson, and D. F. Hall, 1961. Experimental harvest of the Steller sea lion in Alaskan waters. U.S. Fish and Wildlife Serv., Spec. Sci. Report: Fisheries: No. 371

U.S. Department of Commerce, 1966. Economic development of Alaska, (EDA). A report to the President. U.S. Government Printing Office, Washington, D.C.

U.S. Department of Interior, 1966. Natural resources of Alaska. U.S. Government Printing Office, Washington, D.C.

U.S. Fish and Wildlife Service, 1974. Marine mammals. Administrative and status report. Federal Register, v. 39, No. 150, Aug. 2, 1974, p. $27922-27930$. 
IX. COMMENTS AND RESPONSES

A. Letters for which no comments are required.

B. Letters with responses. 
A. Letters without responses. 


\section{DEPARTMENT OF AGRICULTURE \\ OFFICE OF THE SECRETARY \\ WASHINGTON, D. C. 20250}

Apri1 13, 1976

Honorable Sidney R. Galler

Deputy Assistant Secretary

for Environmental Affairs

Department of Commerce

Washington, DC 20230

Dear Mr. Galler:

The Department of Agriculture has reviewed the DEIS concerning the "Consideration of a Waiver of the Moratorium and Return of Management of Certain Marine Mammals to the State of Alaska."

It would appear that the Department of Agriculture has no administrative authority in any laws or regulations that the proposed actions would affect and, therefore, does not object to the proposal. The DEIS is well written and presumably adequate.

The Department appreciates the opportunity to comment.

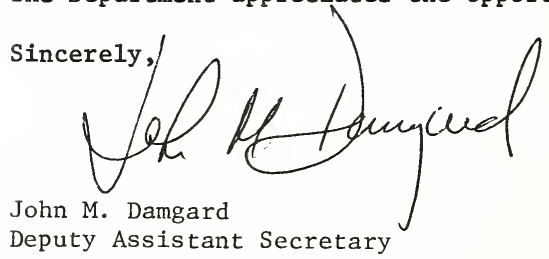

Enclosure 


\section{United States Department of the Interior}

OFFICE OF THE SECRETARY

WASHINGTON, D.C. 20240

In Reply Refer to:

MAY 121976

FWS/ES

ER $76 / 277$

Dear Mr. Schoning:

This is in regard to your request of March 1976 for the Department of the Interior's review and comments on the draft environmental statement for Consideration of a Waiver of the Moratorium and Return of Management of Certain Marine Mammals to the State of Alaska.

This is to inform you that the Department has no comments to offer.

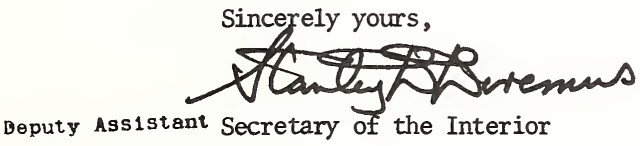

Mr. Robert W. Schoning

Director, National Marine

Fisheries Service

Department of Commerce

Washington, D. C., 20230
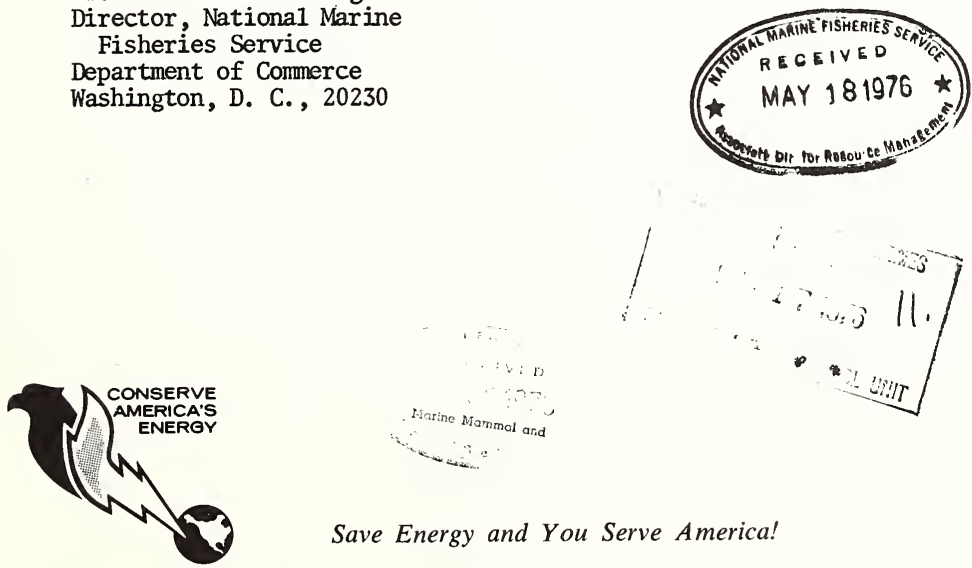

Save Energy and You Serve America! 


\section{DEPARTMENT OF FISH AND GAME}

1416 NINTH STREET

SACRAMENTO, CALIFORNIA 95814

(916) 445-3531

March 29, 1976

Mr. Robert W. Schoning, Director

National Marine Fisheries Service

Hational Oceanic and Atmospheric Administration

3300 Whitehaven Parkway

Washington, D. C. 20240

Dear Bob:

The Governor has referred Mr. Sidney R. Galler's recent letter regarding the draft Environmental Impact Statement (prepared jointly by the National Marine Fisheries Service and the Fish and Wildlife Service) on the State of Alaska's request for a waiver of the moratorlum and return of management for certain marine mammals, to this office for comments.

We believe the action requested by the State of Alaska is in conformance with the intent of the Marine Mammals Protection Act of 1972 and proposes no irreversible or irretrievable comitments of marine mamal resources or other living marine resources.

We further belleve it is essential that certaln populations of marine mamals be managed to allow the proper utilization of all living marine resources which provide food, employment, and recreational enjoyment for a large number of citizens of the country.

The action requested by the State of Alaska is, therefore, in our opinion, in the best interest of the nation and should be approved and implemented without delay.

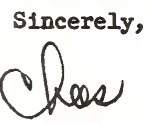

Director

cc Governor Brown

$$
\begin{gathered}
\text { imd } \\
\text { Atii }=0 \text { i976 }
\end{gathered}
$$

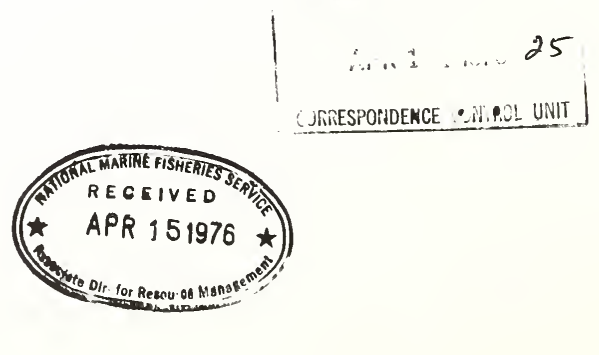


DEPARTMEIN'T OF GAME

600 North Capitol Way/Olympia, Washington

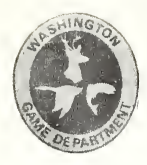

98504
Game Commisston

Cluude Bekins, Seattle. Chusrman

Glenn Galbrattb, W'ellponst

Frank L Cassidy, Jr. Vancouver

Arthur S. Coffsn. Yuksma

Elizabeth W. Meudoucroft. Tucoma APR 161976

Archie U. Mills. Wenutchee

Director / Carl N. Crouse

Assistant Directors / Ralpb W Larsin

Jack S. Wuyland

April 12, 1976

Mr. Sidney R. Galler

Deputy Assistant Secretary

For Environmental Affairs

Department of Commerce

Washington, D.C. 20230

Dear Mr. Galler:

Your draft environmental impact statement--Consideration of a Waiver of the Moratorium and Return of Management of Certain Marine Mammals to the State of Alaska--was reviewed by our Game Management Division. Comments follow.

We found your draft to be rather unique in approach. The analysis concentrates on species and socio-economic issues rather than the impact which this proposed administrative action would have on the total physical environment. We feel this type of approach is appropriate in this case.

Your proposed waiver of moratorium and return of management of certain marine mammals to the State of Alaska is supported by our department.

Thank you for sending your draft. We hope our comments will be helpful.

$$
\text { Sincerely, }
$$

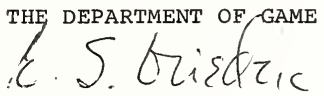

Eugene S. Dziedzic, Asst. Chief

ESD : CV Environmental Management Division

CC: Reade Brown

Agencies 


\section{NATIONAL FISHERIES INSTITUTE, INC.}

May 4, 1976

Mr. Jack Gehringer

National Marine Fisheries Service

3300 Whitehaven Street, N. W.

Washington, D.C. 20235

Dear Mr. Gehringer:

The National Fisheries Institute would like to comment

on the proposed waiver of moratorium on the taking and importing

of marine mammals and marine mammal products, as announced in the

Federal Register on April 9, 1976.

Specifically, the Institute favors the establishment of a cooperative state-federal government management system for

marine mammal resources, as described in the proposal as subpart H, 50 CFR, Part 216.

While moratoria may have been necessary in the past in order to preserve certain of our marine mammal resources, the stocks in question have grown to the extent that the moratorium is no longer necessary.

In addition, interest and capabilities in marine mammal resource management among the States has increased very noticeably in recent years. The Institute is pleased to observe that the federal government is allowing the individual States a larger role in resource conservation decision making and policy implementation, in acknowledgement of this trend.

While the Institute views the proposed waiver as an indication of an increase in flexibility on the part of the federal government, the Institute still maintains that all parties involved should place more emphasis on insuring that the fundamental needs of world societies are considered.

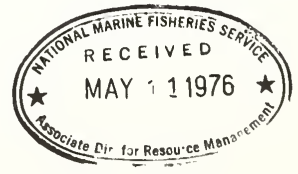


That is, management of a marine mammal population at the level of its optimum sustainable population, whatever that may be, should not mean that we should allocate inordinate portions of $f$ ishery resources, or allow destruction of fishery resources in order to provide that population with food. The world wide human food needs must have first priority.

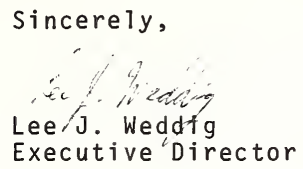




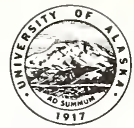

U N I VER S I T Y OF A L A S K A

FAIRBANKS, ALASKA 99701

March 25, 1976

Dr. Sidney R. Galler

Deputy Assistant Secretary

for Environmental Affairs

Department of Commerce

Washington, D.C. 20230

Dear Sid:

I have read with interest the draft environmental impact statement of the directors, National Marine Fisheries Service, National Oceanic and Atmospheric Administration, and Fish and Wildlife Service, Department of the Interior.

For some time I have been professionally acquainted with affairs of the above mentioned federal services and have enjoyed occasional collaboration with them.

I have had rather close association with the Alaska Department of Fish \& Game, its Commissioner and his able staff. It has been a pleasure to communicate with these men, to have joined some of them in research upon marine mammals and to record their valuable contributions to scientific knowledge and higher education. The Alaska Department of Fish \& Game comprises individuals with long and varied experience with the animals of Alaska in the diverse environments of the State.

I am particularly impressed by the knowledge that I have found in the Department of the marine mammals of Alaskan coasts and waters. This knowledge shows clearly in the evaluations of status of species of marine mammals, the management of which is proposed to delegate to the State of Alaska.

I believe that the proposal to delegate authority is in the public interest. It will assure the studious attention for the public benefits that can be derived from the attention of these men of high scientific repute in the State's service which has been maintained at a high professional level. They will continue their close personal and service relations with their federal colleagues. In addition, through associations that are mutually beneficial, the State's Department will have close association with scientists of the University of Alaska, and through them with scientists in national and international institutions concerned with marine mammals.

In these several respects the worthy purposes of the Marine Mammals Act will be carried forward for science, education and increasing enjoyment 
U N I V E R S I T Y OF A L A S K A

Dr. Sidney R. Galler

$-2-$

March 25, 1976

of our citizens in the mammals of the sea, which are among the most interesting and instructive of natural objects.

With my best wishes after a long period of non-acquaintance.

Sincerely,

Xarry

LAURENCE IRVING

Advisory Scientific Director

\& Professor of Zoophysiology

$\mathrm{LI} / \mathrm{bm}$ 


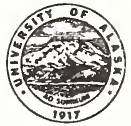

UNIVERSITY OF AlaSKa

FAIRBANKS. ALASKA 99701

Institute of Merine Science

8 Apri1, 1976

Dr. Sidney R. Galler

Deputy Assistant Secretary for Environmental Affairs

The Assistant Secretary of Commerce

Washington, D.C. 20230

Dear Dr. Galler:

I am writing to you to state my comments on the Draft Environmental Impact Statement, CONSIDERATION OF A WAIVER OF THE MORATORIUM AND RETURN OF MANAGEMENT OF CERTAIN MARINE MAMMALS TO THE STATE OF ALASKA, as requested in your letter of $8 \mathrm{March}, 1976$. I wish to record my endorsement of the proposition for waiving the moratorium and the transfer of management authority of selected species to the State of Alaska as indicated in the DEIS.

The substantial experience and excellent record of the Alaska Department of Fish ant Game in the conservation and management of marine mammals since statehood is an outstanding example of professional and competent wildlife management. Alaska stands in a unique position among the states with regard to the economic importance and magnitude of its marine mammal resources. The Department of Fish and Game, together with other agency and institutional capabilities, have provided the foundation for one of the leading regional endeavors of the world in the field of marine mammal biology. Rational and wise management and conservation of that resource depends upon continued and improved research and analysis of marine mammal biology and of its interactions with other components of the northern marine ecosystem. Such studies are currently underway and involve close cooperation and collaboration among state, federal and university staff in Alaska. International Joint enterprises have also recently been initiated with Soviet and Japanese scientists and managers. The very important Bering Sea fishery (approximately $4 \%$ of the total world catch) in which those nations play a major role demands attention and our best efforts at understanding and regulating possible conflicts between commercial fishermen and marine mammals. Native subsistence hunting is yet another of the vital and complex parts of the marine mammal situation in Alaska which needs attention.

I am firmly convinced, based upon the history of marine mammal work in' Alaska since 1959, that the extremely important goals stated can be best achieved in the foreseeable future by return of authority to the state of Alaska and by further expansion of the well developed collaborations within the shate, nation and among the foreign countries involved. We can not afford to ignore the fundamental importance of these considerations for Alaska, the nation and the world.

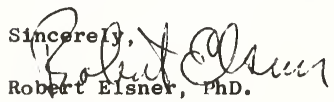

Professor of Marine Science $e^{E A S E R E P L Y B Y A I R M A I L}$

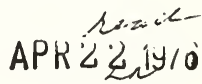




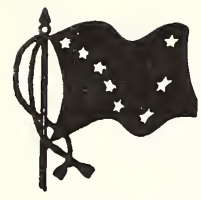

\section{Alaska Professional Hunters Association, Inc. \\ P. O. BOX 4-1932, ANCHORAGE, ALASKA 99509 PHONE 907-279-7837}

OFFICERS

PRESIDENT - STAN FROST - ANCHORAGE VICE PRESIDENT - LYNN CASTLE - FAIRBANKS SECRETARY - GEORGE PALMER - PALMER TREASURER - IRISH MC GUIRL - ANCHORAGE
Mr. Sidney Galler

Deputy Asst' Secretory

for Environmental Afcairs

The Assistant Secretory of Commerce

Washinaton, D.C. 20230

\section{BOARD OF DIRECTORS}

KEN FANNING - FAIRBANKS

CHARLES GRAY - FAIRBANKS

CLARK ENGLE - ANCHORAGE

DARRELL FARMEN - ANCHORAGE

L.Castle

Box 1616

Fairbanks, Ak 99707

April 13,1976

Derr Sirs,

I am writing on behalf of the Alaska Professional Huters Asscciation. Inc. in response to your letter of 8 march, 1976 reference comments on the 'proposed draft environmental impact statement' - Consideration of a Walver of the Moritorivin and Return of manacement of Certain morine mammals of the state of Alaska, Vol 1 ; Vol 2.

The APHA. Ine. is in agreement with, and endorses, the conditions and stipulations as set forth in the draft statement, with very few, and minor, exceptions. We question protibition of use of arreraft for polarbear on the hiah seas from the bio. logical, practical and enforcement stantpoint - however fram a political (national concern, etc.) stand point such prohibition may be not only desirable, but absolutely necessary.

We should like to request that the APHA, Inc. be considered to testify at any future hearings, etc. involving waiver of the Moritorium,

Please excuse this handwritten note- I am curremlly in the field \& away from my dest. Tyank you

c.c. APHA, Ine, Anchorage

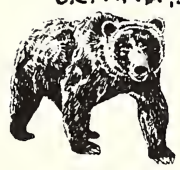

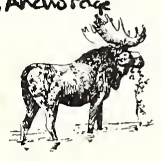

Lynn M.Castle

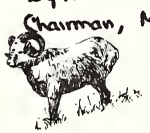

PLEDGED FAIR CHASE

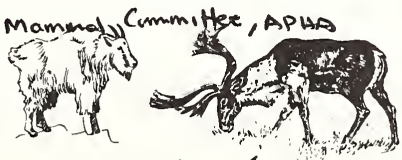

APR 2916 


\section{National Wildlife Federation}

141216 TH ST., N.W., WASHINGTON, D.C. 20036

Phone: $202-797-6800$

A.PP ? ? 1976

April 19, 1976

Sidney R. Galler

Deputy Assistant Secretary for

Environmental Affairs

U.S. Department of Commerce

Washington, D.C. 20230

Dear Mr. Galler:

Reference is made to your 8 March 1976 letter with its enclosed Draft Environmental Impact Statement (DEIS) entitled: "Consideration of a Waiver of the Moratorium and Return of Management of Certain Marine Mammals to the State of Alaska."

It seems clear to us that the Congress, in developing the legislation which eventually became the Marine Mammal Protection Act (MMPA) of 1972, was keenly sensitive to the states traditional role in managing resident species of wildlife. Also, the Congress was, and is, aware that the states have a much greater capability than the Federal

Government, personnel and funding wise, to manage such resources.

It is not surprising, then, that the language contained in the MMPA and its legislative history makes it evident the Congress never intended that the moratorium on the taking of marine mammals be invoked any longer than is required to ensure that the welfare of each species is adequately safeguarded. Further, the MPA provides for the Federal Government to transfer management authority back to any state whose laws and regulations are determined to be consistent with the purposes of the Act.

The best statistical data available now indicate that population levels of all nine species of marine mammals are satisfactory and that the State of Alaska is in a position to manage these species under the provisions of Federally-reviewed regulations and laws which are consistent with the spirit and intent of the Act.

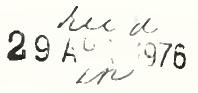




\section{National Wildlife Federation}
Sidney G. Galler
$-2-$
April 19, 1976

This is to advise you, therefore, that the National wildlife Federation (NWF) supports the proposal to waive the moratorium and return management authority to the State of Alaska on the nine species of marine mammals described in the DEIS.

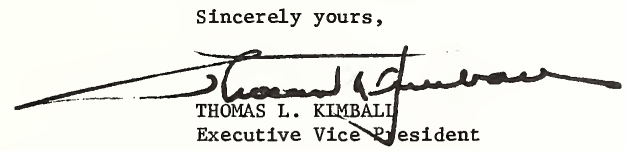

cc: Chairman, Senate Commerce Committee

Chairman, House Merchant Marine \& Fisheries Committee

Chairman, CEQ

Director, FWS

Director, NMFS

Director, Alaska Dept. of Fish and Game

NWF Directorsand Staff

Urban C. Nelson, Executive Dir., Alaska Wildlife Fed. \& Sportsmen's Council 
OFFेICERS

PALMER A. "KIT" CARSON

President

BERTRAM A. WEBER

Vlce President

WILLIAM N. LANE, III

Secretary

JOSEPH C. FERRARA

Treasurer

DIRECTORS

KEITH BATES

RICHARD H. BEGALKA

DR. BARRY O. BEGUESSE

PALMER A. "KIT" CARSON

DR, ANTHONY F. CASTROGIOVANNI

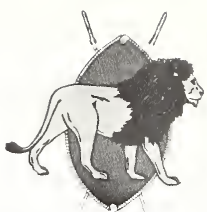

Safari Club International

Chicago Chapter

THOMAS C. CECKER

HYLAND B. ERICKSON

JOSEPH C. FERRARA

HERBERT C. GWINN

ROMAN HUPALOWSK

WILLIAM N. LANE, III

NED PAYNE

ROBERT E. ROSS

JOHN UHLARIK

BERTRAM A. WEBER

ROBERT S. ZIEMEK

Mr. Raymond C. Hubley, Jr., Chief

Mari ine Mammals and Endangered Species Division

National Marine Fisheries Service

National Oceanic and Atmospheric Administration

U.S. Department of Commerce

Washington, D.C. 20230

Dear Mr. Hubley:

I have recently been sent a copy of the U.S. Department of Commerce and the U.S. Department of the Interior Interagency Task Group's

Draft Environmental Impact Statement germane to "Consideration of A Waiver of the Moratorium and Return of Management of Certain Marine Mammals to the State of Alaska".

I have read andanalyzed this Draft Environmental Impact Statement.

I am in full accord with proposed action to waive the moratorium, with

limitations, on nine species of marine mammals, in waters off Alaska, and grant to that state authority under the waiver to regulate taking within state jurisdiction and on the high seas outside state jurisdiction in waters off Alaska (1) for sport, cominercial, and subsistence purposes, and (2) takings for scientific research and takings incidental to commercial fishing operations.

I, therefore, endorse your professional and courageous actions.

Very truly yours,

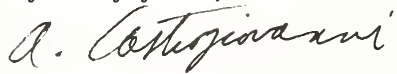

Anthony F. Castrogiovanni

$\mathrm{AFC} / \mathrm{ms}$

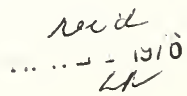




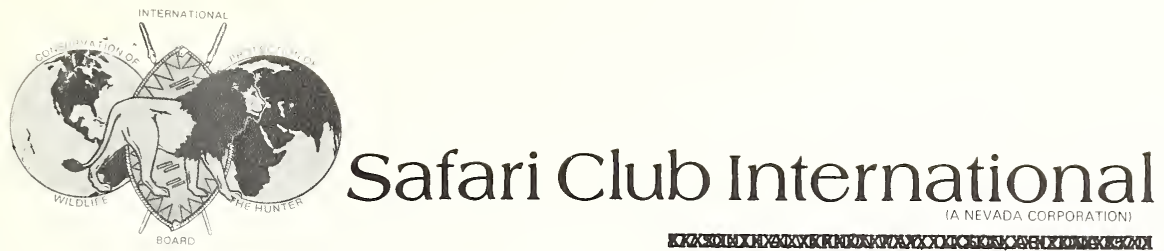

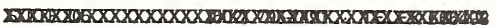

$$
\begin{aligned}
& \text { C.J OFFICERS } \\
& \text { C.J. MCELROY } \\
& \text { HYLAND B. ERICKSON } \\
& \text { President } \\
& \text { JAMES SCHMALZ } \\
& \text { Vice Presiden } \\
& \text { H. NORDEN VAN HORN } \\
& \text { Vice President } \\
& \text { CHARLES BECKER, JR } \\
& \text { Secretary } \\
& \text { KYLE DeFOOR } \\
& \text { DIRECTORS } \\
& \text { COL. THOMASE, BASS } \\
& \text { President-Nat'i Capitol Chapter } \\
& \text { JACK BEAL } \\
& \text { President-Florida Chapter } \\
& \text { WILSON H. BROWN } \\
& \text { PALMER A "KIT" CARSON } \\
& \text { President-Chicago Chapte } \\
& \text { DR. JIM CONKLIN } \\
& \text { President-Pittsburgh Chapte } \\
& \text { COTION GORDON } \\
& \text { FRANK E. GREEN } \\
& \text { President-Houston Chapter } \\
& \text { WILLIAM D. HART } \\
& \begin{array}{l}
\text { WILLIAM D. HART } \\
\text { President-Rocky Mountain Chapter }
\end{array} \\
& \text { GEORGE ISAACS } \\
& \text { President-Hawaii Chapter } \\
& \text { LEE E. JURRA. } \\
& \text { President-Indiana Chapter } \\
& \begin{array}{l}
\text { HAROLD A. KEATS } \\
\text { JACK LEEDS }
\end{array} \\
& \begin{array}{l}
\text { JACK LEEDS } \\
\text { nesota Chapter }
\end{array} \\
& \text { SEYMOUR H. LEVY }
\end{aligned}
$$

April 3, 1976

Please Reply To: 4615 N. Camino Nuestro Tucson, Arizona 85705

Mr. Raymond C. Hubley, Jr., Chief

Marine Mammals and Endangered Species Division

National Marine Fisheries Service

National Oceanic and Atmospheric Administration

U.S. Department of Commerce

Washington, D.C. 20230

Dear Mr. Hubley:

The SAFARI CLUB INTERNATIONAL is a democratic organization consisting of 22 chapters located throughout the United States. In addition, there are about a dozen affiliated autonomous groups as well as thousands of individual associate members. All subscribe to the thesis "Conservation of Wildlife and Protection of the Hunter".

We have recently been sent a copy of the U.S. Department of Commerce and the U.S. Department of the Interior Interagency Task Group's Draft Environmental Impact Statement germane to "Consideration of a Waiver of the Moratorium and Return of Management of Certain Marine Mammals to the State of Alaska".

We have read and analyzed this Draft Environmental Impact Statement. The SAFARI CLUB INTERNATIONAL is in full accord with proposed action to waive the moratorium, with limitations, on nine species of marine mammals, in waters off Alaska, and grant to that State authority under the waiver to regulate takings within State jurisdiction and on the high seas outside State jurisdiction in waters off Alaska (1) for sport, commercial, and subsistence purposes, and (2) takings for scientific research and takings incidental to commercial fishing operations. This waiver would allow the taking, for the above listed purposes, of not more than:

\author{
Beluga Whales - 360 \\ Northern Sea Lion - 15,000 \\ Spotted Seal - 20,000 \\ Ribbon Seal - 500 \\ Harbor Seal - 6,500
}

\author{
Ringed Seal - 20,000 \\ Bearded Seal - 9,000 \\ Polar Bear - 250 \\ Sea Otter - 3,000 \\ Walrus - 3,000
}

Data included in the Draft Environmental Impact Statement indicates that this limited harvest of these nine species of marine mammals is 
Mr. Raymond C. Hubley, Jr.

well within their ability to sustain with no adverse effects upon their individual populations.

We, therefore, endorse your professional and courageous actions.

Very truly yours,

SAFARI QLUB INTERNATIONAI

séymur H. Levy, Chairmap

Nat lonal Legislative Act(ion Committee

SHL:hm1 


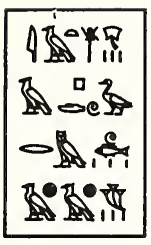

\section{THE WILDLIFE SOCIETY \\ SUITE S176 - 3900 WISCONSIN AvE., N.W.}

WASHINGTON, D. C. 20016

May 11,1976

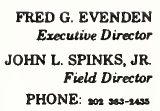

Sidney R. Galler

Deputy Assistant Secretary for

PAP 17976

Environmental Affairs

U.S. Department of Commerce

Washington, DC 20230

Dear Mr. Galler:

This letter is in response to your March 8, 1976 letter with its enclosed Draft Environmental Impact Statement (DEIS) entitled: "Consideration of a Waiver of the Moratorium and Return of Management of Certain Marine Mammals to the State of Alaska."

In studying the history of the Marine Mammal Protection Act (MMPA) it would appear to us that Congress was acutely aware of the state's traditional role in managing resident species of wildlife. It would also appear that Congress realizes the greater capability of the state, as opposed to the Federal Government, to manage their resident wildlife resource. This has been especially true in recent years with the decreased personnel and funding levels available at the Federal level for the management of wildlife resources.

Present population levels of all 9 species of marine mammals under consideration are satisfactory, according to the best statistical data available. Based upon these data and the language contained in the MMPA indicating that Congress never intended that the moratorium on the taking of marine mammals be invoked any longer than necessary to insure the adequate safeguarding of each species, The Wildlife Society supports the proposal to waive the moratorium and return management authority to the State of Alaska for the 9 species of mammals described in the DEIS.

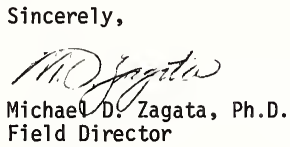

$\mathrm{MDZ} / 1 \mathrm{y}$

cc: Chairman, Senate Commerce Committee

Chairman, House Merchant Marine \& Fisheries Committee

Chairman, CEQ

Director, FWS

Director, NMFS

Director, Alaska Dept. of Fish and Game

NRCA Members

Council, TWS

R. Sparrowe

Alaska Chapter Presidents, TWS Official Publications

JOURNAL OF WLDLIFE MANAGEMENT • WILDLIFE MONOGRAPHS • WILDLIFE SOCIETY BULLETIN 
B. Letters with responses. 


\section{STANTE OP ALASKA}

DEPT. OF ENVIRONMENTAL CONSERVATHON

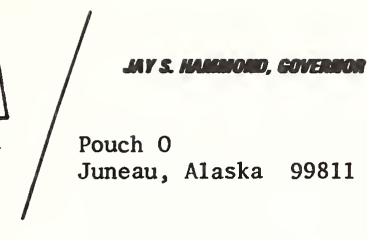

Sidney R. Galler

Deputy Assistant Secretary

for Environmental Affairs

APK $\approx 119 / 0$

U.S. Department of Commerce

Washington D.C. 20230

Dear Mr. Galler:

Thank you for the opportunity to review and comment on the DEIS concerning a waiver of the moratorium and return of certain marine mammals to the State of Alaska.

This Department strongly supports the concept of returning the management of marine mammals to the State of Alaska.

The present program governed by the Marine Mammal Protection Act of 1972 limits the taking of animals except for subsistence and scientific purposes. This policy has permitted certain species to increase above the optimum carrying capacity. If populations continue to increase, a number of impacts will be felt, including: increased competition for space, food and breeding habitat; greater susceptibility to disease; displacement; dietary shift; high infant mortality and lower pregnancy rates. These indices have been observed for several species regulated by existing management plan.

The State of Alaska, Department of Fish and Game, is in a better position to effectively manage Alaskan marine mammals to an "optimum sustainable population" level.

\section{Page Specific Comments}

$\mathrm{Pg} .8$ - The quotas 1 isted for the 10 species appear confusing in comparison with those shown in Table 4, page 99. It is assumed that the quotas take into account the $50-60 \%$ unretrieved loss of walrus and seals due to sinking. It also appears the quotas are far above the estimated annual take under the proposed action.

Pg. 105 - The 40 - $50 \%$ unretrieved loss of walrus perhaps should be given greater consideration and discussion. If the harvesting of these animals under the State's management program will continue to yeild a $50 \%$ non-retrieval, this should be included in the establishment of harvest quotas.

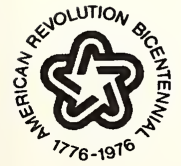

“1776-A TRIBUTE FROM OUR STATE TO OUR NATION-1976"

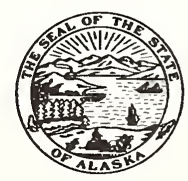


Sidney R. Galler

Page 2

April 15, 1976

Pg. 114 - There is a need to identify the criteria for determining an orphaned walrus calf as opposed to an abandoned calf, a non-orphaned calf, or a juvenile. Although it may not be large, a harvest loophole appears to exist and may cause regulatory problems.

Pg. 128 - Statement (1) notes that Marine mammals may be taken legally only "with a hand-held rifle using a centerfire cartridge, except rifles capable of fully automatic fire" is ambiguous. The statement should simply identify the minimum caliber weapon and ammunition acceptable.

I hope these brief comments will permit an expeditious review of this proposal and hasten the return of management to the State of Alaska.

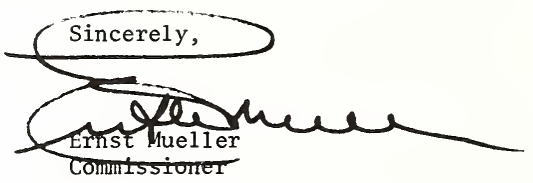

EM:GC:sg 
State of Alaska

Department of Environmental Conservation

\section{Comment:}

Pg. 8 - The quotas listed for the 10 species appear confusing in comparison with those shown in Table 4, page 99. It is assumed that the quotas take into account the 50 - $60 \%$ unretrieved loss of walrus and seals due to sinking. It also appears the quotas are far above the estimated annual take under the proposed action.

\section{Response:}

The extent of the waiver is based upon the optimum sustainable population of each species and not upon the State's estimate of current take and its projected near-term needs. The NMFS quotas include both retrieved and nonretrieved harvests, whereas the FWS quotas include.only retrieved take.

\section{Comment:}

The 40 - 50\% unretrieved loss of walrus perhaps should be given greater consideration and discussion. If the harvesting of these animals under the State's management program will continue to yield a 50\% non-retrieval, this should be included in the establishment of harvest quotas.

\section{Response:}

The unretrieved loss of animals was included in the waiver consideration.

\section{Comment:}

Pg. 114 - There is a need to identify the criteria for determining an orphaned walrus calf as opposed to an abandoned calf, a non-orphaned calf, or a juvenile. Although it may not be large, a harvest loophole appears to exist and may cause regulatory problems.

\section{Response:}

These terms will be defined in State regulations, should it become necessary. Comment:

Pg. 128 - Statement (1) notes that Marine mammals may be taken legally only "with a hand-held rifle using a centerfire cartridge, except rifles capable of fully automatic fire" is ambiguous. The state should imply identify the minimum caliber weapon and ammunition acceptable.

\section{Response:}

The Fish and Wildlife Service approved in 0ctober 1976 revised State regulations on minimum caliber weapons that may be used for hunting walrus. In June 1977, the ALJ did not recommend minimum calibers for the other species, but minimum calibers may be set in final or revised regulations. 


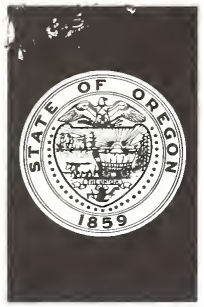

\section{EXECUTIVE DEPARTMENT}

\section{INTERGOVERNMENTAL RELATIONS DIVISION}

240 COTTAGE STREET S.E.

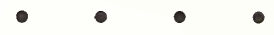

SALEM, OREGON 97310

ROBERT W. STRAUB GOVERNOR

STAFFORD HANSELL Director

April 14, 1976

\section{Apk 2 \% 1976}

Sidney Galler

Deputy Assistant Secretary

for Environmental Affairs

The Assistant Secretary of Commerce

Washington, D.C. 20230

Dear Mr. Galler:

Re: Consideration of a Waiver of the Moratorium \& Return of Mgmt. of Certain Marine Animals to Alaska PNRS \#7603 4630

Thank you for submitting your draft Environmental Impact Statement for state of oregon review and comment.

Your draft was referred to the appropriate state agencies. Department of Fish and Wildlife offered the enclosed comments which should be addressed in preparation of your final Environmental Impact Statement.

We will expect to receive copies of the final statement as required by Council of Environmental Quality Guidelines.

Sincerely,

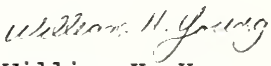

William H. Young

Administrator

WHY : $1 m$

Enclosure 


\title{
OREGON PROJECT NOTIFICATION AND REVIEW SYSTEM
}

\author{
STATE CLEARINGHOUSE
}

LOCAL GOVERN DIENT
PELATIONS DIV.

Intergovernmental Relations Division

240 Cottage Street S.E., Salem, Oregon 97310

APR 131976

$\mathrm{Ph}: 378-3732$

\section{PNRS SIAIE REVIEW}

Project \#: $-760 \overline{3} \quad 4 \quad 6 \overline{3} 0$ Return Date: $4-9-76$

\section{ENVIRONMENTAL IMPACT REVIEW PROCEDURES}

1. A response is required to all notices requesting environmental review.

2. OMB A-95 (Revised) provides for a 30-day extension of time, if

necessary. If you cannot respond by the above return date, please call the state Clearinghouse to arrange for an extension.

\section{ENVIRONMENTAL IMPACT REVIEW} DRAFT STATEMENT

( ) This project does not have significant environmental impact.

( ) The environmental impact is adequately described.

$(x)$ We suggest that the following points be considered in the preparation of a Final Environmental Impact statement regarding this project.

( ) No comment.

\section{REMARKS}

The Oregon Department of Fish and Wildiffe supports the State of Alaska's proposed walver of the marine mammal moratorium. This subject was addressed and approved as a resolution at a recent meeting of the Pacific Marine Fisheries Commission with this department's support.

other comments are:

Page 9, Vol. 1. Monitorlng state laws, management and regulations should be a state responsibility with minimum federal control.

Federal review of state regulations should have a time limit, such as "The federal review will be accomplished within 120 days." Should comments not be made within that period, the regulations are approved as submitted.

Page 53, Vol. I. The concept of single populations must be accepted for harbor seais; hence, the moratorium waiver for that species cannot be questioned.

RELEIVED

MAR 191976

FISH \& WILDI IFE 
State of Oregon

Executive Department - Intergovernmental Relations Division

Comment:

Page 9, vol. I. Monitoring state laws, management and regulations should be a state responsibility with minimum federal control.

Federal review of state regulations should have a time limit, such as "The federal review will be accomplished within 120 days." Should comments not be made within that period, the regulations are approved as submitted.

\section{Response:}

50 CFR Section 216.106(f) subpart $H$ and Section 18.56(f) subpart F, state: "As soon as practicable. . . the Director. . . shall determine whether or not to finally disapprove the State laws and regulations. The Director's determination shall be made within 90 days after publication of the notice described in section 216.106(e) [section 18.56(e)] unless a hearing is held..."

Comment:

Page 53, vol. I. The concept of single populations must be accepted for harbor seals; hence, the moratorium waiver for that species cannot be questioned.

\section{Response:}

The hearing record and the administrative law judge's recommended decision support a finding that there is a single population of land-breeding harbor seals. 


\section{ODOPERATIVE EXTENSION SERVICE}

UNIVERSITY OFALASKA

FAIRBANKS ALASKA 99701

$80 \times 95151$

April 16, 1976

Sidney R. Galler

Deputy Assistant Secretary

for Environmental Affairs

U.S. Department of Commerce

Washington, D.C. 20230

Dear Mr. Galler:

In response to your letter of March 15, 1976, please find enclosed the comments concerning the draft environmental impact statement "Consideration of a Waiver of the

Moratorium and REturn of Management of Certain Marine

Mammals to the State of Alaska: (Vols. I and II). These

comments were made by one of our marine advisory agents.

APR ? 61976

Sincerely,

pines W. Natchews

James W. Mat thews

Director

$\mathrm{JWM} / \mathrm{ba}$

Enclosure

cc: Raymond C. Hubley, Jr.

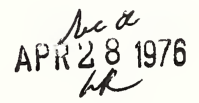

UNIVERSITY OFALASKA, ANO U.S. OEPARTMENT OF AGRICULTURE COOPERATING 


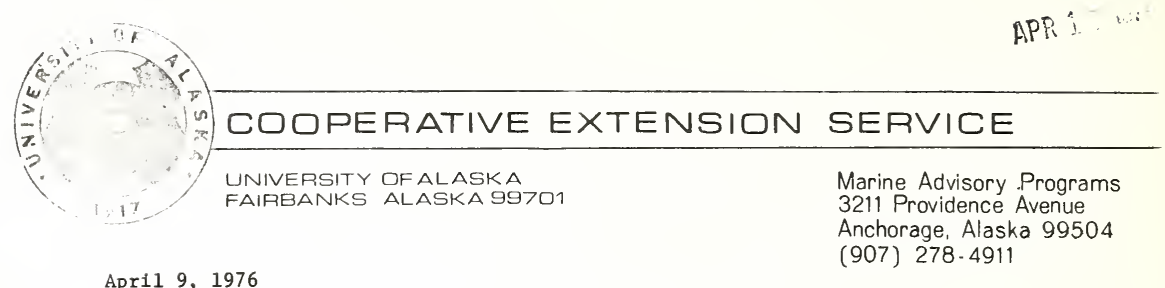

April 9, 1976

Dr. James Matthews, Director

Cooperative Extension Service

University of Alaska, Box 95151

Ant $2+310$

Fairbanks, AK 99701

Dear Jim:

I have read over the draft Environmental Impact Statement "Consideration of a Waiver of the Moratorium and Return of Management of Certain Marine Mammals to the State of Alaska: (Vols. I and II).

In general, I find no fault with the DEIS, with the exception of several small points which could stand clarification. Examples: in several places, "beluga whales" Is stated to include other specles of toothed whales (77-79, Vol. I), and similarly a status report on beluga and whales, dolphins and porpoises (p. 145, Vol. II). Does this indicate the State is opting for the management of all whale species? On page 10, Vol. I, last paragraph, baleen whales should be included in the phylogenetic listing.

On page 14, Vol. I, the first three criteria for assessing marine mammal population above optimum levels may be very difficult to deal with for pelagic spectes.

The table on page 8, Vol. I, is difficult to interpret as presented. Do the numbers indicate the number/species taken? If so, do they include, or are they 1imited to, those animals taken by native subsistence hunting?

Page 29, Vol. I, states that the "population data for polar bears has not been sufficiently analyzed ... to construct a reliable population model for this species." Perhaps such a population model should be developed before sport hunting is reopened for this species (or, for that matter, before allowing further subsistence hunting as currently permitted by the Marine Mammal Act).

These are largely picky criticisms of a generally fine DEIS. Thank you for the opportunity to read and review it.

Sincerely,

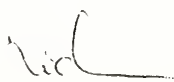

Richard S. Lee

Assistant Professor

Marine Science Education

$\mathrm{RSL} / \mathrm{dmr}$

Enclosure

UNIVERSITY OFALASKA. AND U.S.DEPA 
University of Alaska; Cooperative Extension Service

\section{Comment:}

In general, I find no fault with the DEIS, with the exception of several small points which could stand clarification. Examples: in several places, beluga whales" is stated to include other species of toothed whales ( $p$. 77-79, vol. I), and similarly a status report on beluga and whales, dolphins and porpoises (p. 145, vol.II). Does this indicate the State is opting for the management of all whale species?

\section{Response:}

To mention species other than those proposed for a waiver in such areas as food web diagrams ( $p .77-79$ ) and in State-supplied biological data ( $p .145$, vol.II) in no way connotes that "the State is opting for management of all whale species." The proposed action described is the return of management for nine species of marine mammals, which includes only one cetacean species, the beluga whale (Delphinapterus leucas).

\section{Comment:}

On page 10, vol.I, last paragraph, baleen whales should be included in the phylogenetic listing.

\section{Response:}

Baleen whales are not a part of the proposed action and therefore are not discussed in detail in the impact statement.

\section{Comment:}

On page 14, vol.I, the first three criteria for assessing marine mammal populations above optimum levels may be very difficult to deal with for pelagic species.

\section{Response:}

Except for beluga whales, all of the nine species haul out on ice or land at least to breed. Therefore the first four indicators should apply. Dietary components are determined from stomach content analyses.

\section{Comment:}

The table on page 8 , vol.I, is difficult to interpret as presented.

\section{Response:}

This table has been retained and appears at page 8 of vol. I, of the FEIS. Notwithstanding the above comment, the table is considered to be a useful means for graphically depicting the extent of the waiver. 


\section{Comment:}

Page 29, vol. I, states that the "population data for polar bears has not been sufficiently analyzed...to construct a reliable population model for this species." Perhaps such a population model should be developed before sport hunting is reopened for this species (or, for that matter, before allowing further subsistence hunting as currently permitted by the Marine Mammal Act).

\section{Response:}

The results of the polar bear population modeling were presented at the 1976 . ALJ public hearing and have also been incorporated in the FEIS. 


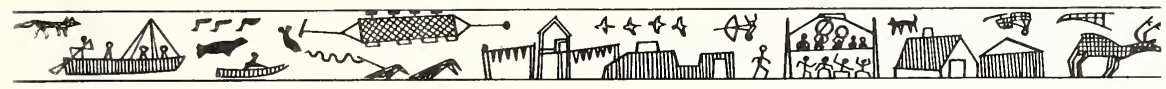

\section{BERING STRAITS NATIVE CORPORATION}

PO. BOX $1008 \cdot$ NOMIE, ALASKA $99762 \cdot 1907 D$ 4A3.5252

APR 211976

April 12, 1976

Mr. Sidney R. Galler

Deputy Ass't Secretary for

Environmental Affairs

The Assistant Secretary of Commerce

Washington D. C. 20230

Dear Mr. Galler:

We have reviewed the Draft Environmental Impact Statement of the Consideration of a Waiver of the Moratorium and Return of Management of Certain Marine Mammals to the State of Alaska and make the following comments on the statement:

\section{Administrative Hearings}

We strongly urge that any administrative hearings include Nome as one of the location to solicit input from the people that would be directly impacted by the waiver of the moratorium. Further that announcement of hearings will also include press releases and letters to Native Organizations involved, as the Federal Register is circulated only to limited number of readers and in most cases received one month after the date of publication due to it's 3 rd or 4 th class mail rating.

\section{The People, the Economy and Hunting Pressures in Alaska}

Contrary to the statement made on page 93, Volume I, quote, "Native subsistency dependency has decreased since white man began the colonization of Alaska. The granting of 40 million acres in fee title land and nearly a billion dollars to the $\mathrm{Na}-$ tives under provisions of the Alaska Native Claims Settlement Act (ANCSA) should accelerate this trend. It has been said that ANCSA will have as great an impact upon the Alaska Native's traditional way of life as did their early encounter with white man's 


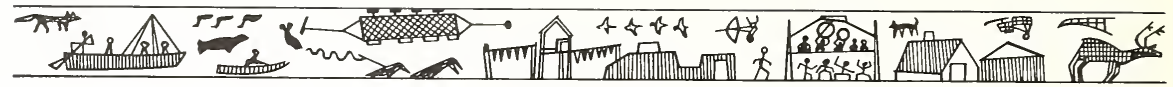

Mr. Galler

Page Two

April 12, 1976

culture." End quote. The impact of ANCSA on village life style has been very little. The individual stockholders of regional and village corporations have had very little direct benefits or income from the ANCSA. The following are the individual resident stockholder share from the ANCSA distribution checks:

$$
\begin{array}{r}
1973 \text { - } \$ 182.00 \\
1974 \text { - } 92.23 \\
1975-78.41
\end{array}
$$

We don't foresee any major change in the lifestyle and subsistence dependence of the Alaskan Native Village Residents on marine mammals in the near future.

III. Current Takings of Marine Mammals in Alaska not Affected by the Requested Action

Page 97 \& Page 101

A. Hunting by Alaska Natives: This section of the Environmental Impact Statement implies that taking of marine mammals by Alaska Natives would not be affected by the transfer of management to the State of Alaska. Appendix "H", Alaska Administration Code Titles - Regulations Pertaining to Marine Mammals with Proposed Amendments, hardly reflects this. Section 5 AAc 81.350 Marine Mammal Hunting establishes seasons and bag limits for hunting units in all of the State of Alaska.

Unit

Open Season Bag Limit

(1) Seal \& Beluga

(a) Sea Lion Units $1-26$

No Closed Season 10 Sea Lions*

* The taking of sea lions in excess of 10 is permitted only under the terms of a permit which may be issued by the Commissioner. 


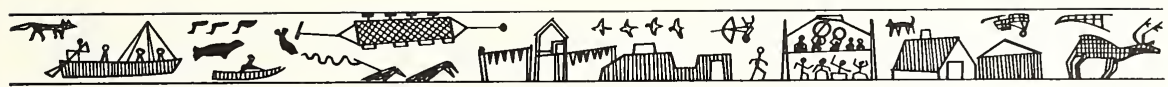

Mr. Galler

Page Three

April 12, 1976

(b) Beluga

Units 1-8 and

in waters South

of Aleutian Is-

land Chain No Open Season

Units 9-26 Closed
Season 2 Belugas*

* The taking of belugas in excess of 2 is permitted under the terms of a permit which may be issued by the Commissioner.

(2) Seal

(a) Harbor or Spotted

Units $1-26$

No Closed

Season 4 Seals*

* Provided that taking of harbor or spotted seals

in excess of 4 is permitted only under the terms

of a permit which may be issued by the Commissioner. No such permit shall be issued for commercial take

of harbor seals south of the Aleutian Peninsula.

(b) Ringed, Bearded

and Ribbon.

Unit 9 , North

of the Aleutian

Island \& 10, 17- No Closed

26 Season

10 Seals*

* Provided that the taking of ringed, bearded or ribbon seals in excess of 10 is permitted only under the terms of a permit which may be issued by the Commissioner.

The bag limits provided in these regulations severely limits the number of marine mammals that would be taken by Alaska Natives with the exception of walrus. Also on pages 114, 115, 116, 117, 118 and 125 , the Environmental Impact Statement makes references to unlimited bag limits for subsistence 


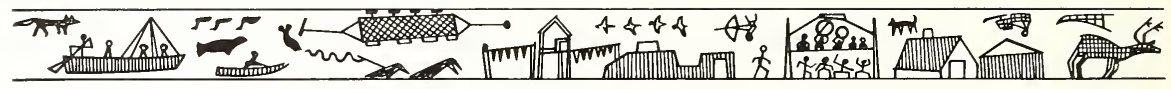

Mr. Galler

Page Four

April 12, 1976

take by Alaska Natives and hunting units north of Bristol Bay. The proposed bag limits under Section 5 AAC 81.350 applies to all units and makes no special reference to subsistence take by Alaska Natives who depend upon and utilize marine mammals for food. Also the State Regulations groups the species of seals, ie., (a) harbor or spotted seal, (b) ringed, bearded and ribbon, and establishes bag limits for each group. These regulations as presently drafted would seriously limit the take of Alaska Natives for subsistence purposes. On page 125, there is references made that $A D F$ \& G recognizes the historical need of Alaska Natives for subsistence harvest, that the regulations have been drawn in a manner that allows natives subsistence take and that there is a year open season on seals with no bag limits. This is not so, the case, according to the Proposed State Regulations.

IV. Appendix I - Proposed Federal Regulations

A. Section 216.103/18.53

Review of State Laws

and Regulations - General

"Part (b)", states, "Section 109 of the Act provides that on or after December 21, 1972, no state may adopt any law or regulations, or enforce any existing law or regulation, which relates to the taking of marine mammals or which in effect nullifies an exemption or exceptions created by the Act, unless such law or regulations have been previously reviewed by the Director and determined by him to be consistent with the provisions of the Act and the regulations in this part. Emphasis supplied.

We feel that the proposed state hunting regulations does not meet the conditions of this part, as currently written, as they do not provide for subsistence take of Alaska Natives or make any special references to subsistence taking except for polar bear and walrus. 


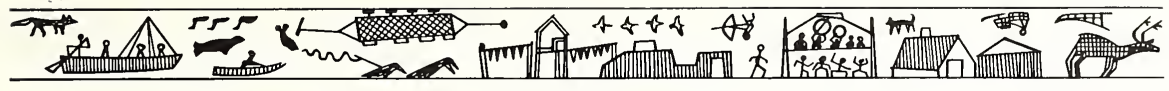

Mr. Galler

Page Five

April 12, 1976

B. Section 216.105/18.55
Approval of State Laws
And Regulations - Criteria

The criteria established for approval of State Laws and Regulations completely by-passes the subsistence needs of the Alaska Natives and yet makes references to recreational use, part (g), part (11). We feel that subsistence needs of the Alaska Natives should have precedence over recreational use or incidental catch of marine mammal.

$$
\begin{aligned}
& \text { V. Appendix F - Alaska Game } \\
& \text { Management Policies }
\end{aligned}
$$

Polar Bear Policy, page F-4 states "Recreation is the most important use of polar bears. Recreational uses include: sport hunting in it's various forms, observations and wilderness experiences etc." Page F-5 states, "The Department recognizes recreational hunting as the dominant use of polar bears in the state. Page F-5 states "The Department does not consider the harvest of polar bears primarily for food, a proper use, nor does it consider the sale or barter of hides, meat or other parts, a proper use and will oppose these uses."

It is evident from the above statements that the State of Alaska does not consider subsistence use of polar bear a proper use and could possibly prohibit such use in the future.

VI. The State Fish and Game Regulations are confusing and leaves one wondering which section of the regulations have precedence over the other.

$$
\begin{gathered}
\text { Section } 5 \text { AAC } 81.320 \\
\text { Big Game Hunting }
\end{gathered}
$$

Units

(3) Bear, polar

$18,22,23 \& 26$
Open Season

$10 / 15-5 / 31$
Bag Limits

One bear every four regulatory years, by permit only. 


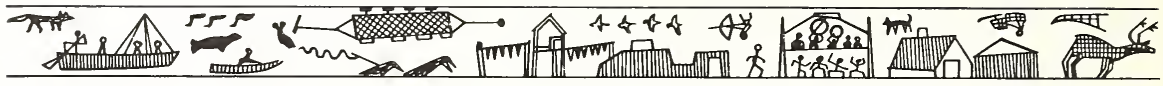

Mr. Galler

Page Six

April 12, 1976

Section 5 AAC 90.020

Definitions

(2) "Bag limit" means the greatest number of game species permitted to be taken by any one person in the unit or portion of a unit in which the taking occurs: however, additional numbers of species may be taken in another designated open unit or portion of a unit where a greater limit on such species is prescribed: in no case may the total or cumulative bag for one person exceed the limit set for the unit or portion of a unit in which the additional game was taken:

\section{VII. (D) The Impact of the Proposed Federal Regulations and the State Management Program Page 110 of Volume I EIS}

1. Impact on Species Population - Polar Bear

The following statement is made "Proposed state regulations would allow licensed residents to take one polar bear per year for food without a permit: this statement is not in agreement with section $5 \mathrm{AAC}$ 81.050 of the proposed state hunting regulations.

\section{Socio-Economic Impacts - Page 119}

Statement on page 122 says - "Other cash sources of income have been greatly reduced. Sale of polar bear hides, for instance, had once brought $\$ 3,000$ to $\$ 5,000$ to the successful non-native hunter. A guided polar bear hunt earned at least half as much. An estimated of 20 to 30 polar bears are annually harvested by Eskimos and because of current restrictions on sale of hides, the estimated total loss of income derived from polar bear hunting is above $\$ 150,000$. Page 124, Table 6 - Impact of requested action, if implemented, on activities discussed in this report.

Activity

Subsistence Hunters
Probable Results of State Management

a. Some restrictions in take such as limits on polar bear. 


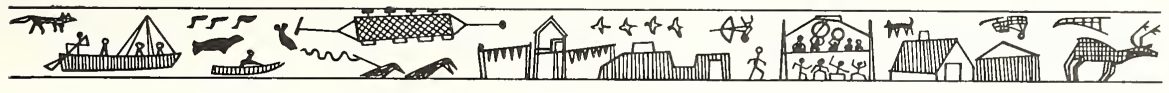

Mr. Galler

Page Seven

April 12, 1976

b. Removal of restriction on sale of skins.

The proposed state regulations state under Article 5, Use of Game - Section 5 AAC 81.20, Purchase and Sale. The purchase, sale or barter of game or parts of game is permitted with the following exceptions:

(5) Polar bear or parts of polar bear taken under terms of a permit issued by the commissioner.

I suppose that the lack of mention on sale of barter of polar bear or parts of polar bear taken for food indicate that such use in allowable without restrictions. Based on the Alaska Game Management Policy Statements, it is evident that they do not support such use and even states that they would oppose such use.

\section{General Comments}

A. Again, we emphasize that Administrative Hearings be held in Nome to get as much input as possible from the Alaska Natives in Northwest Alaska who would be directly affected by the transfer to State Management.

B. We strongly oppose the proposed state regulations as currently written (appendix H) as they are too restrictive; they do not make special reference to taking of seals for food; the language is confusing and in most cases, are not in agreement with various statements made in the Environmental Impact Statement.

C. We realize that the moratorium and game management is primarily designed for the conservation of marine mammals and for balanced ecosystem. We do, however, feel strongly that the Alaska Native Needs were not emphasized enoughi. particularly in the proposed federal regulations and the state regulations. If all taking was terminated on any species of seals or walrus, the effect would be to bring to point of starvation to these small Alaskan Native Villages that depend primarily on sea mammals for food. We ask that other forms of taking of marine mammals be terminated first before you force the Alaska Natives to the point of breaking the law. 


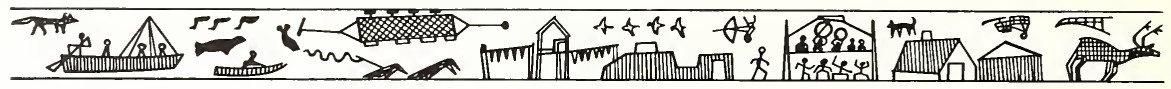

Mr. Galler

Page Eight

April 12, 1976

We are not opposed to the waiver of the moratorlum but we'll oppose the transfer of management to the State of Alaska under the current proposed state regulations.

We hope that every consideration will be given to our concerns and that favorable results will occur. Further concerns and comments will be made during the administrative hearings.

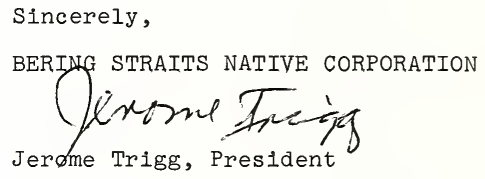

$\mathrm{JT} / \mathrm{sw}$

cc: Senator Ted Stevens

Senator MIke Gravel

Representative Don Young

12 Regional Nat1ve Corporations

Bering Straits Region Village Corporations

Governor Hammond

James M. Brooks

John R. Twiss, Jr.

Representative Robert L. Legett

Representative Leonor $\mathrm{K}$. Sullivan

Bud Walsh

Gary Longley, Chairman for Nome Fish \& Game

Carl Grauvogel

Advisory Committee

Frank Ferguson

Larry Davis

$\mathrm{Nels}$ Anderson 
Comment:

Contrary to the Statement made on Page 93, Volume I, quote, "Native subsistency dependency has decreased since white man began the colonization of Alaska. The granting of 40 million acres in fee title land and nearly a billion dollars to the Natives under provisions of the Alaska Native Claims Settlement Act (ANSCA) should accelerate this trend. It has been said that ANCSA will have as great an impact upon the Alaska Native's traditional way of life as did their early encounter with white man's culture." End quote. The impact of ANCSA on village life style has been very little. The individual stockholders of regional and village corporations have had very little direct benefits or income from the ANCSA. The following are the individual resident stockholder share from the ANCSA distribution checks: 1973-\$182.00; 1974-\$92.23; 1975-\$78.41. We don't forsee any major change in the life-style and subsistence dependence of the Alaskan Native Village Residents on marine mammals in the near future.

\section{Response:}

Although the economic situation varies between villages and councils dependent upon contact and proximity to non-Native areas of habitation, the statement, albeit general, is considered valid.

\section{Comment:}

Hunting by Alaska Natives:... These regulations as presently drafted would seriously limit the take of Alaska Natives for subsistence purposes. On page 125 , there is a reference made to that $A D F \& G$ recognizes the historical need of Alaska Natives for subsistence harvest, that the regulations have been drawn in a manner that allows Native subsistence take and that there is a year open season on seals with no bag limits. This is not so, the case, according to the Proposed State Regulations.

\section{Response:}

The regulations discussed in the comment above were modifications drafted by the NMFS and FWS of State regulations then in effect. (appendix $H$ of the DEIS). These regulations are no longer a part of the proposed action and have been removed from the FEIS. The regulations proposed by the State to be effective if the waiver is approved are located in appendix $G$.

Response cannot be made to the remaining concerns addressed in the letter as they relate to the issues of fact discussed at the hearing and are the subject of the waiver. All comments however have been noted and will be given due consideration before any action is taken. When and if the waiver is implemented, State laws, regulations, and policy statements may have to be changed to be in compliance with the stipulations and intent of the Marine Mammal Protection Act of 1972. All noted discrepancies such as those related to the polar bear will thereby be eliminated. 
Nunam Kitlutsist1

Box $26 ?$

Bethel, Alaska 99559

Apr11 14, 1976

H. Will am Newman, Chatrman

Joint FIS/NMFS

Marine Mammal Task Force

Fish and Wildife Service

Washington, D.C. 20240

Dear Mr. Newman,

We have just finished reading the draft environmental impact statement "Consideration of a Waiver of the Moratorium and Return of Management of Certain Marine Mammals to the State of Alaska." In that the 1972 Marine Mammal Moratorium responded in part to the distinct, and inseparable relationship between native Alaskan subsistence hunters and marine nammals through the "native exclusion," our region of 1ce-seal and walrus hunters are quite concerned by' the State's efforts to regain management control. Our experlence with the State as a manager of game resources has been unpleasant, and our villages have established our region's position as one of opposition to the return of management to the State of Alaska of both walrus and the remaining species of marine mammals.

The lower Yukon and Kuskokw m river drainages is the site of $\frac{1}{4}$ of all native villages in the State of Alaska. There is no regional govermment, and the Association of Village Council Presidents, an ad-hoc government of the elected municipal and traditional council leaders of our 56 member villages, represents the collective village Interets .. Nunam Kitlutsist1 is the environmental advisor for AVCP, and during the past two years, N.K. has attempted to explain the complicated issue of marine mammals, the State's request for first walrus return, and then the State's request for return of the remaining species of marine mammals to State management. Our villages point to two basic facts concerning the State's management plansil)that the State has failed to meet its obligation to manage its resources in regard to beneficial users, and has failed to adaquately provide the funds for support of subsistence communities dependent upon renewable resources; and 2) the State of Alaska has little regard for the future consequences of massive Federal development plans in the Bering Sea that will make all assumptions concerning existing ecological conditions in the Bering Sea null, and a drastic revision in human popelation influences on Bering Sea marine mammal populations as a secondary consequence of federal OCS off-shore and on-shore plpeline development.

In 1974, the villages of our region filled out a subsistence calendar each day in each of their subsistence households. (Table 1) Our region complled a food inventory of 14.2 million pounds of food. Marine mammals are the staple part of our coastal villages diet, and the oll from the seal serves as the maln liquid component of our fried fish/game diet among all our villages. Unlike other regions of the State, our region's renewable environment is rather bleak. There are no massive migrations of game into our region, 


\section{Page 2}

and harvest is a dajly task. Our leaders continue to point out that we are at our level of maximum sustained yield for our region. In 1900, when early investigators explored our region, these men calculated our population, then rich in walrus and caribou:, at 15.000; in 1976, we are without the walrus and the caribou, and face intrusions by high seas fishing fleets on our salmon, and our population is again at 15,000. Our villagers continue to report that they must monitor their harvest strictly, for if they interfere with the ecological balance of their hunting areas, there is no place else to go, for the villages surrounding treir territory are already harvesting the available surplus. Our villages do not waste, and yet our people know we are in trouble, and in need of professional game management help to plan for the future when massive federal development program shall open up our region. We have asked the State for this assistance, and have been met with a de afear.

Our region has carefully researched the expenditure of State funds, particularly the allocation of Pittman-Robertson funds for game management, and we note that the Bethel and the Yukon Delta have the lowest per capita expenditure of any region in the State. Contrary to published statements within the DEIS, the State has no information of any validity about our region's marine mammal harvest, nor has the State invested eithortime or manpower in our region to determine population. We are a region that depends on its marine mammals; the mammals are the only food many of our coastal villagers have for most of the year, yet the State continues to spend its game management funds on sport and recreational hunting areas. Our villages are convinced that a return of marine mammal management to the State will not produce a change in the state's allocation of its supposed marine mamnal professional manpower, but will merely produce an opening for the State to start up sport hunting of marine mammals again. Our villages believe that the sport hunting of marine mammals for Alaska's urban population is the State's only interest in having the marine mammals returned to State jurisdiction. Our villages also fear that a return to the State will eliminate the federal funds currently being spent on marine manmals through ocS related efforts, and federal and state combined funding for research and management in our region will be completely negated.

The "native exclusion", while harming natives in their 1imited market places for the sale of surplus hides and by=products, has placed the issue of user classes out of the State's continuing constitutional crisis amongst user classes. The State continues to tell its citizens that all are equal, yet when the issue of funding is examined, native Alaskans dependent upon the resource for their very livelihood learn that their regions recieve the least attention unless recreational hunting objectives of the State are also satisfied so as to warrant State expenditures. Recreational users clearly outweigh native subsistence uses. (Table 2)

Our region does not wish to see the "native exclusion" be replaced with the State's 
definition of proper ma agement, particularly in light of the Federal Government's intent to lease in the Bering Sea and set aside large parts of the western Alaskan land mass for future highways, pipelines, and ports. Our summation of the DEIS is that its factual basis of information up to 1973 is inadaquate to allow so critical a decision as return of management to take place. We find that the information concerning our lives in the villages is a set of assumptions, and little time has been taken to adaquately review the existing social, economic, and subsistence conditions within our villages. Section E, "The Economy, and Hunting Pressures in Alaska" is useless, and Section 3 "the Alaskan Native Economy" displays a freightening ignorence of economic conditions in our villages today, the effects of technology, and future consequences of growth.

Our villages did not know poverty until a technological culture found them. Through technology, the gun and the machine, game populations were eliminated(the baluga, caribou) and new area was opened up for recreational hunters(the AVCP region to airplane hunters from Alaska's urban areas). Now, many of our people face poverty of spirit and hunger for the Ir land game is.gone. Our coastal villages have not faced this problem yet, because sport hunting populations do not live on the Bering Sea. On-shore development in relation to OCS will have drastic changes in the demography of Western Alaska. The statement on page 92 is most illuminating: "New residents of the State of Alaska, if they do hunt, are expected to favor such big game animals as moose, caribou, deer, sheep, and goats." When these populations of new Alaskans settle on the Bering Sea coast, our villagers expect two things to happen:a)an increase in the sport effort on marine mammal in that land mammals populations are severely depressed in our region now; b) enactment of special sport bunts by the State to legitimize the recreational hunters on our coasts regardless of its impact on native subsistence needs. Page 125 explains that the State generally regulates seasons to benefit subsistence take, and because ice-seals "tend to be available in quantity during the severest weather, only local residents are able to harvest." This statement does not consider the near future when resident populations along the Bering Sea coast will contain sport hunters who demand "equal-use" under the State's consitution. The State refuses to discuss the issue of preference among beneficial hunters, and our villages reason this is their objection to State management.

Environmental degradation of the Bering Sea biota is the larger question facing our subsistence culture. 011 spills and a degradation of the Bering Sea biomass, a natural by $=$ product of frontier exploration and development are extremely sensitive issues to our region. The State is unable to assume the task of pre-planning and monitoring these crises, and our villages believe that the Federal Government is also unwilling to examine the consequencesof its policies on native subsistence culture as a direct consequence of off-shore and on-shore OCS indwced changes. N.K. notes that the OCS program is completely overlookec, and that the DEIS fails to take into consideration the funding and monitoring required of the State to protect 1ts management. of marine mammals. On page 138, the 
proposed action which would involve waiving the moratorium and transfering management to the State lists as an administrative consequence an added burden on the State, but somehow the DEIS concludes that the State Department of Fish and Game, which is strapped for funds, and under tremendous pressure from diverse interests, will somehow reverse its present characteristic of spot checking subsistence areas and concentrating on active recreational hunting zones to satisfy no doubt the wishes of the Federal managers of marine mammals. It is clear that the Federal government is clearly aborgating the intention of Congress by glossing over the severe consequences of OCS in the Bering Sea while refusing to ask the State of Alaska to scrutinize its management policies in ordex to have marine mammals controls returned to the state. It is the undexstanding of our villages that the Marine Mammal Moratorium was not a stop-gap, an interlude of "punishing states" for a short pexiod of time before automatically returning control upon request, but that the Congress had ordered a thorough review of all past efforts, and that the Congress had given special recognition to native alaskan as primary beneficial users of the marine mammal populations.

AVCP recommends that new sections be added to adaquately examine OCS and native preferential harvest. AVCP further recommends that individuals writ ing the report visit native alaskan villages dependent upon marine mammals and familiar with the State of Alaska's management policies to gather pertinent information on the issues listed above prior to writting the final EIS.

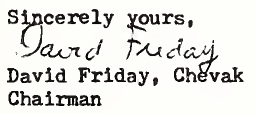

Sincerely yours,$$
\text { Saced truday }
$$$$
\text { David Friday, Chevak }
$$$$
\text { Chairman }
$$ 
REPORT ON SUBSISTENUE HARVEST IN THE

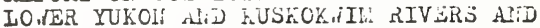
THE BERIIG SEA CCAOTIIHE BETIVEEN

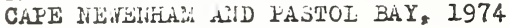

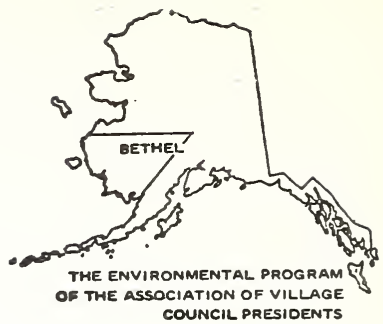

In liarch, 1973, the unorganized borough government of the lower YukonKuskokwim Kiver valley's, the Association of Villase Council Presidents, recosnized that enactment of the Alaska lative claims settlement Act of '1971 changed the concepts of open land in rural Alaska. Subsistence villages traditionally have wandered over the land seeking food. The only boundaries were establish through concent of villases. Nitn NiCSA, rural Alaska's lands would be divided into townsnips, with delinite ounership.

The 56 villages of AVCP, representing an area tise size of tne state of washington, formalized their support for tne continuation of access for suosistence. All villages subscribed to a subsistence document in which all subsistence nunters within $\dot{A V U P}$ were sranted access to native village corporation lands selected under AllCSA, for the purpose of subsistence harvest. AVCP's council leaders feared section 2(c)'s intent, to review all existing programs under i'ederal sponsorsnip, and tre f'ederal and state reserved lands established under AliCSA. Of particular concers to iVCP were Section $17(\mathrm{~b})(3)$ which empowers the Secretary of Interior to situate easements where the Secretary desires them, including native land seleetions, and Sections $17(d) I$ and 2, whica create up to 120 nillion acres of previously unreserved Federal lands for inclusion into National Forests, Parks, dildifie Refuges, and yild and Scenic Rivers, and "public interest" lanas reserved for mineral development.

Wthout firm guarantees from tise Federal and State governments to continue subsistence ard access on these new federal holdings and state selections, AVCP concluded accurate information must be obtained from its villages to display the realities of subsistence and the necessity to continue harvest and right to access for the subsistence hunter within AVCF's new land reservations.

AVCP requested Finnam Kitlutsisti to obtain tnis informatior.. On the following page are the results of the 1974 "Subsistence Calendar." iluram Bitlutsisti surveyed each village to determine tne kinds of food it harvestew each two week period. Nine major calendar forms were developed, one for each of AVCF's identifiable subsistence sub-regions. Each head of the household was mailed a calendar in December, 1974, a total of 2160 calendars. Forty one of AVCY's villages took part in the survey. These villages reported back a total of $12.8 \mathrm{million}$ pounds of food harvested in 1974.

Junam Kitlutsisti's Board will attempt to obtain more specific information in 1976 througn anotner calendar, for. the Board pointed out that tue fisures obtained were low. The per capita average of 6,465 pounds per househola does not reflect the poor king salmon(Chinook) run of 1974, and the lack of berries. The Board of junam Kitlutsit ti believes that a second calenaar would pick up the large amounts or fish and vegetation not reported aurinä 1974 's baseyear, and that a larger number of completed calenciars iroulin be collected.

The 1974 Subsistence Calendar Sumary is designed to alert Federal, State, Hesional Corporation, and local officials of the extent, volume, and econoric dependence of sVCr's villages on tae ioods ilarvested irom the land. 


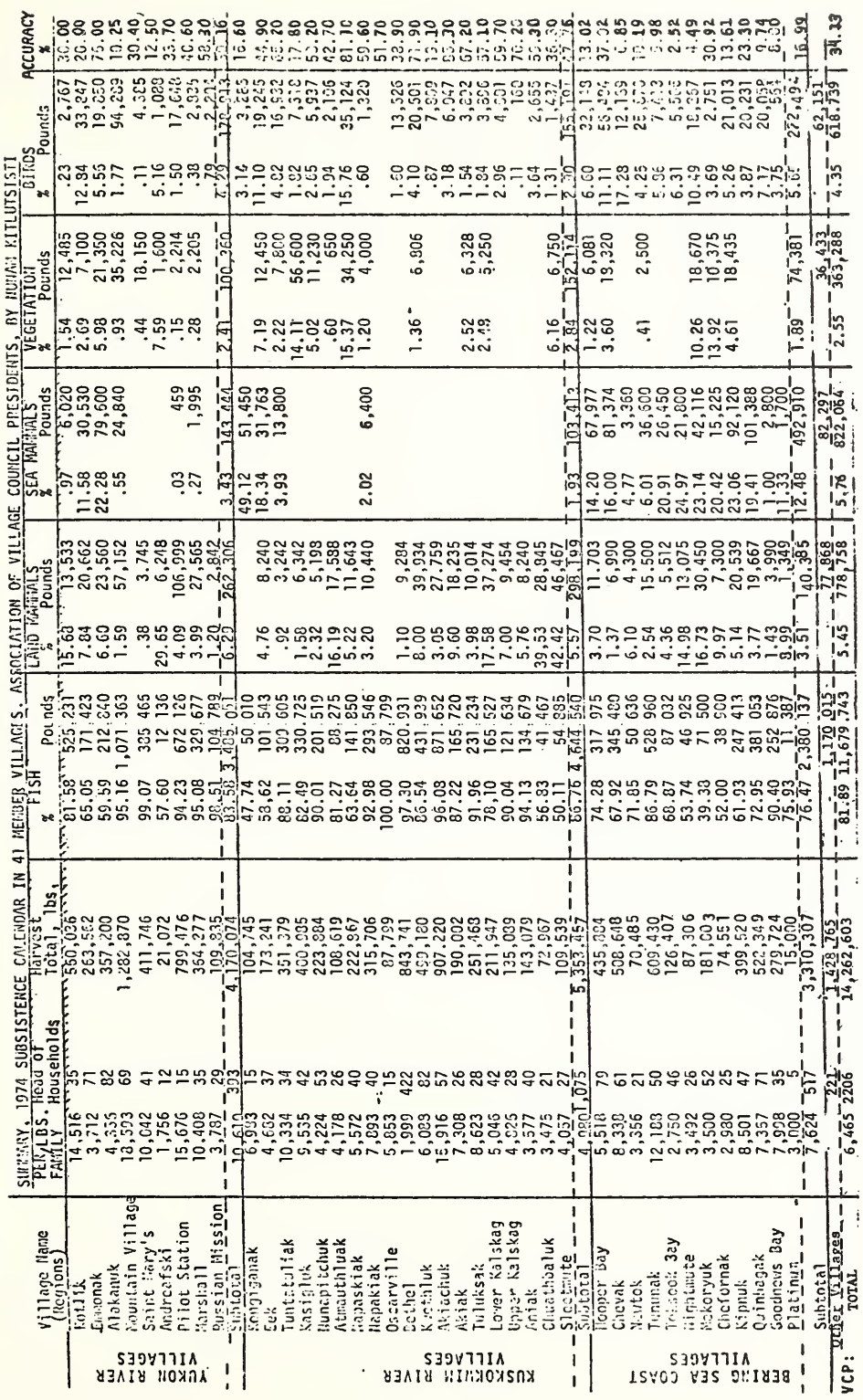


Itemization of Federal Aid Funds(Pittman-Robertson) by Geopgraphic Location

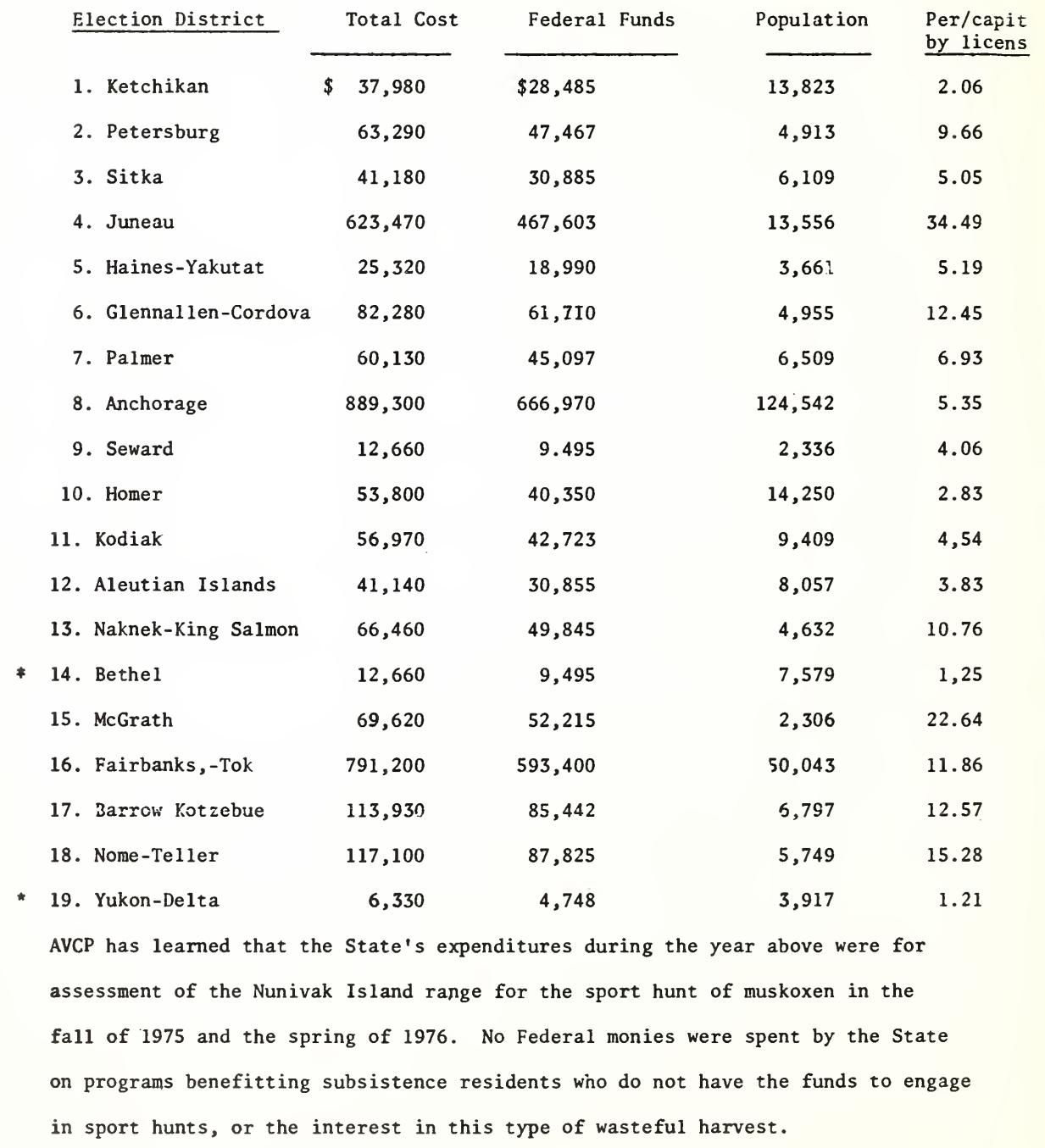


Federal Aid Funds:Pittman-Robertson(Game only)

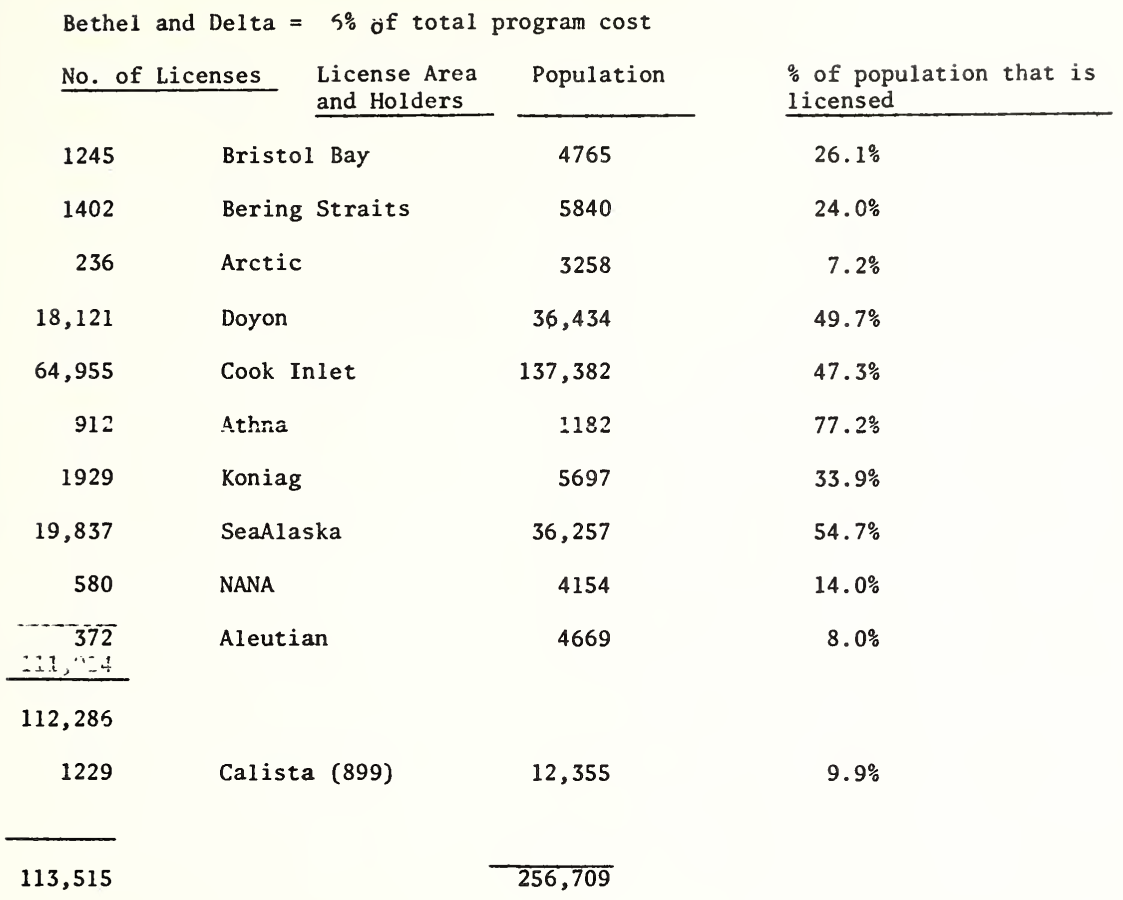

Calista Region: $1 \%$ of the total licenses in the State of Alaska in an area where the majority of the people principally exist by harvesting over $80 \%$ of their food from the land and have toadtradidap? purchased 1 icenses

:Calista region is approximately $5 \%$ of the State's population

:Calista Region receives $.6 \%$ of Federal Aid Funds, while other regions which support sport hunting obtain PittmanRobinson funding. 


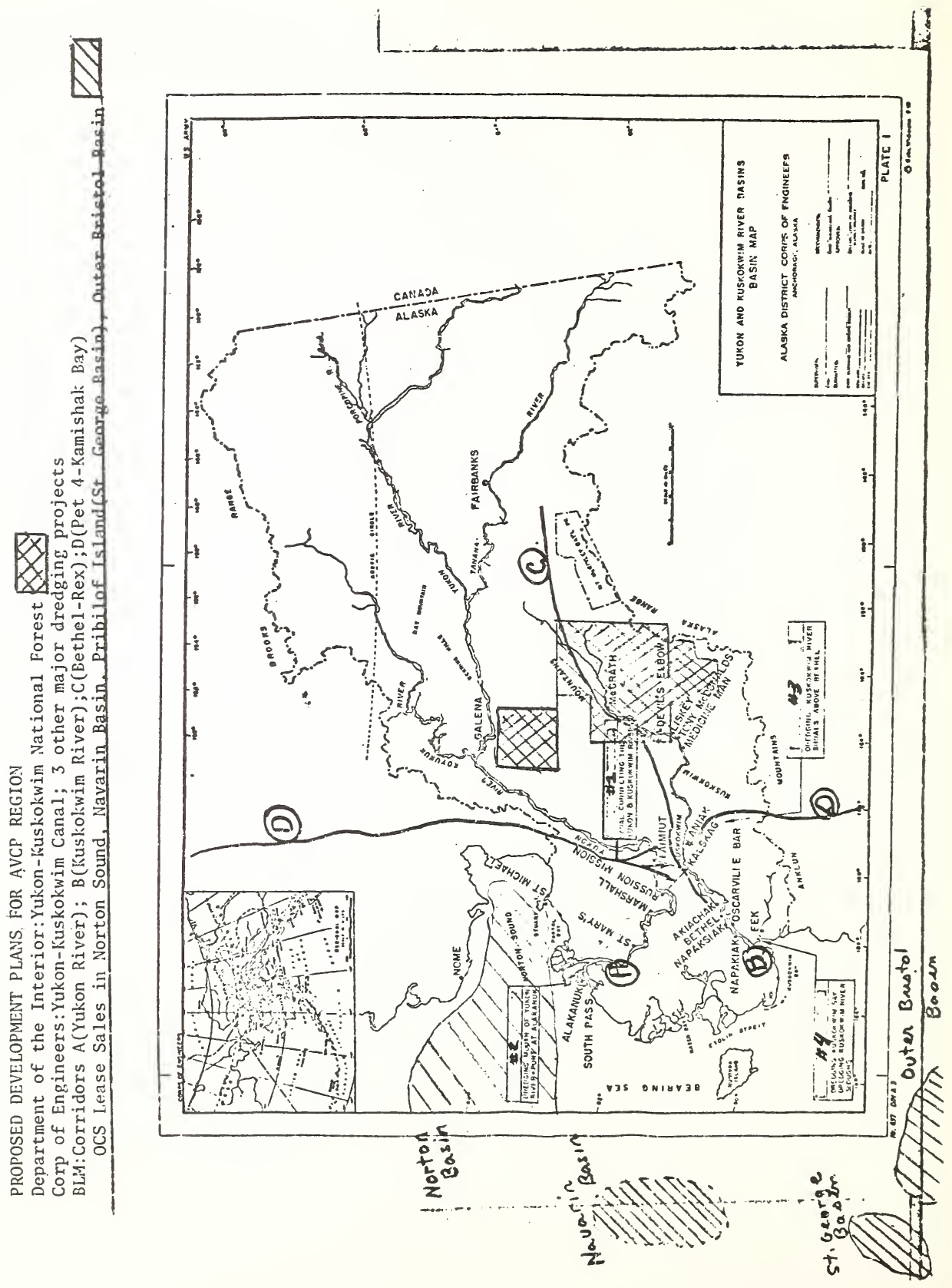




\section{Nunam Kitlutsisti}

\section{Response:}

Responding to the principal issues raised in this letter, the PittmanRobertson Wildlife Restoration Act of 1937 enables a State to propose wildlife projects which, if they meet Fish and Wildlife Service standards of substantiality, may be funded by reimbursement to that state of up to 75 percent of the cost. The Act was intended to assist States in carrying out their self-identified wildlife management responsibilities. However, the Service cannot force a State to conduct specific management programs or require a State to allocate the funds for specific species. Therefore, the comments regarding the allocation of these funds by the State of Alaska are not relevant to our consideration in this statement. Because allocations must be the purview of the Alaska Department of Fish and Game, only the State can provide redress on the conditions to which $\mathrm{Mr}$. Friday objected.

The concerns about the reliability of available harvest data emphasize the need for the types of data that are now able to be gathered for walrus under the waiver implemented for that species in 1976. In addition to assembling more precise and reliable information on population numbers and seasonal migration during 1976, the State reported, for example, that the subsistence take in the Yukon-Kuskokwim area comprised 21 animals--less than 1 percent of the total harvest throughout the State. Because numbers of walrus in the Bering Sea are at or near an all-time high--and the carrying capacity of the environment, we assume that adequate numbers were available to subsistence takers; because there were effectively no restrictions on the size of the subsistence take, we assume further that the subsistence takers took the numbers they needed. The Yukon-Kuskokwim 
subsistence take in 1976 was only 16 less than the total number of animals taken statewide by sport hunters. Thus, rather than the walrus resource being depressed and subsistence hunters having to compete disadvantageously with sport hunters, the resource is healthy in terms of population size, and subsistence takers statewide harvested almost 99 percent of the total 1976 walrus take. If management for the other eight marine mammal species is returned to State control, we expect that harvest-data reliability for them too will improve.

The foremost issue raised in this letter, subsistence use, was lightly addressed in the above response and requires elaboration. The 1976 nine-species waiver-related public hearings in Bethel and Nome primarily addressed the subsistence needs of Natives and other subsistence users. This testimony was thoroughly considered by the administrative law judge before he issued his recommendations, which are discussed for each subject species in this FEIS in sections II.C ("Biology and optimum sustainable population estimates of impacted marine mammals") and III.D ("The impact of the proposed Federal regulations and the State management program"). The preferential subsistence needs are also clearly reflected in the composition of proposed annual harvest limits cited in table 4 of the FEIS.

Responding to the final issue of oil spills and attendant environmental damage, we cannot now anticipate the location, probability, severity, or recurrence interval of future oil spills or accidents because we do not presently know which, when, or where specific tracts of those nominated in the Bering Sea will be leased for development. Federal agencies are, however, assessing marine mammal populations in Alaska and elsewhere in 
the context of potential danger to them due to oiling, and these authorities are preparing appropriate objections to some nominations in Bering Sea waters.

If accidents should occur in leased areas, existing or forthcoming State, Federal, or joint State/Federal oil-spill contingency plans will be implemented to protect or assist any animals that might be affected. Because there is no way to realistically assess the effectiveness of these plans now, it is impractical to address this issue in greater detail than it is in the FEIS. 



\section{ENVIRONMENTAL DEFENSE FUND}

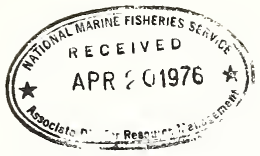

1525 18th STREET, NW, WASHINGTON, D.C. 20036/202 833-1485

Mr. Lynn A. Greenwalt

Director

Fish \&' Wildlife Service

U.S. Dept. of the Interior

Washington, D. C. 20240

Mr. Robert W. Schoning

Director

National Marine Fisheries Service

3300 Whitehaven, N.W.

Washington, D.C. 20235

\begin{tabular}{|c|}
\hline 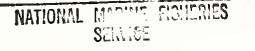 \\
\hline 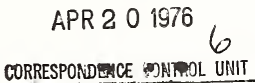 \\
\hline
\end{tabular}

These comments on the above referenced draft environmental impact statement (DEIS), which considers the proposal-that the moratorium on the taking of marine mammals imposed by the Marine Mammal Protection Act of 1972 (hereinafter, MMPA) be waived and management authority be delegated by the federal government to the State of Alaska, are submitted jointly by the Environmental Defense Fund (EDF) and by the groups participating in the Monitor Consortium which are noted in the addendum to this document. As noted in Volume II, Appendix A of the DEIS, the comments of both EDF and of Monitor were sought. Both groups have an 
interest in the subject DEIS and the subsequent outcome of the consideration of the proposed waiver because of the precedent being set by this matter and because of the possible consequences of a waiver for the species considered. Although a similar proposed waiver of the moratorium has already been considered with regard to the Pacific Walrus, new rules governing these proceedings have been promulgated since the close of the Walrus hearings, and these new regulations will govern future proceedings when other states request similar waivers. Consequently, the groups believe that because they represent many individuals in the United States who are concerned with the welfare of marine mammals, they can and should have input into the DEIS and the final decision on the matter. Such participation is consistent with the intent of Congress, evident throughout the MMPA, that the public have input into such decisions. It also should be noted that both of these groups have participated in other proceedings governed by the provisions of the Act -- the authority for these proceedings. Both groups participated in the proceedings entitled "In Re Waiver of Moratorium on Walrus," wherein the question of a waiver of the moratorium under the Act was considered for the Pacific Walrus. Additionally, both groups are participating in the cases involving the taking of porpoise incidental to tuna fishing, which is presently before the United States District Court for the 
District of Columbia on a motion for summary judgment. Some or all of these groups have been involved in recent efforts to win endangered status for all species of sea turtles under the Endangered Species Act. As a result of these activities, the staff of both groups have developed expertise which should be helpful in these proceedings.

As a general matter, it is obvious that the procedures which are adhered to during this process and the final decisions made will have far-reaching consequences for similar actions when other states make requests under the Act for management authority. Consequently, persons who participate in this matter have a substantial burden to carry. It is particularly important in this proceeding that decisions not be made without due consideration of their import, or before a full record has been developed through the hearing process on the questions presented. While we believe that the DEIS is deficient in the respects noted below, we do not mean to be limited in the future to the areas discussed in this document. Other factors may come to our attention after these comments have been submitted, and we believe that the importance of this matter necessitates that we be permitted to explore them at the hearing, certainly before forming any final opinion on the ultimate scientific merit of Alaska's petition. 


\section{Procedure and Process}

The National Environmental Policy Act of 1969 (hereinafter, NEPA), requires that a detailed environmental impact statement be prepared by federal officials prior to any undertaking of certain actions. The draft statement under consideration here is the first step in the process of meeting that requirement, and it must meet the conditions set forth in NEPA. The detailed statement must include the factors set forth in section $102(2)$ (c) of NEPA: 1) the environmental impact of the proposed action, 2) any adverse environmental effects, 3) alternatives, 4) the relationship between short-term uses and long-term productivity, and 5) irreversible and irretrievable resource commitments. In addition, these factors must be considered in the light of the findings of Congress noted in Section 101 (a) of NEPA. One of these findings is that man's activities, including resource exploitation, have had a profound impact on the natural environment. Also, the statement must be made with due consideration of the six goals set forth in section $101(b)$. For reasons set forth in the pages which follow, we believe that this DEIS does not meet the requirements of NEPA. Additionally, the Marine Mammal Protection Act of 1972 requires the Secretaries of Commerce and of Interior to make certain findings and to follow certain procedures before either can waive the moratorium imposed by the Act on the "taking" of marine mammals. Although other sections of the Act must be considered in such a 
decision, Section $109(2)$ is the primary authority for such a waiver. Under that Section, each Secretary must determine that the laws and regulations of the state requesting the waiver are consistent with the provisions of the Act and with the regulations promulgated under section 103 of the Act. In any event, the waiver can extend only to the limits of the jurisdiction of the state. Finally, each Secretary may limit the extent of the waiver insofar as each does not waive all of the provisions of Section 101 of the Act.

It should also be noted that the state requesting a waiver has the burden of showing that its regulations, laws, and management program will be consistent with the requirements of the Act. While such a requirement is implicit in the Act, it is made explicit in the regulations setting the hearing procedures for such waivers, noted in 50 CFR Part 18, subpart G. The DEIS under consideration here does not show that the State of Alaska has met that burden of proof at this point in time. While specific shortcomings will be dealt with below, as a general matter the DEIS does not establish that all of the species and population stocks for which a waiver is sought are at the optimum sustainable population. It has not been established that Alaska will require that takings be accomplished in a humane and non-wasteful manner. Finally, the DEIS does not show that a waiver will be consistent with the goal set out in Section $2(6)$ of the Act that marine mammals "should be protected and encouraged to develop to the greatest extent 
feasible commensurate with sound policies of resource management and that the primary objective of their management should be to maintain the health and stability of the marine ecosystem."

Two final points must be made with regard to process and procedure. While consideration must be given to the interrelationship of each of the nine species to the remaining species, the process itself must be undertaken in an orderly fashion. Thus, each species must be given full and separate consideration in the DEIS and at the hearing, as was the Pacific Walrus last year during the hearings for the proposed waiver for that species. Additionally, proposed federal regulations which appear in Appendix I and subsequently at 41 F.R. 15166 (April 9, 1976) provide standards and criteria for approving state laws and regulations and for monitoring state activities after a waiver has been granted. These regulations should be considered during the hearing on the waiver, and final approval of each should await the outcome of the hearing. This would mean that reconsideration of Part 18, Subpart G of 50 CFR, which became effective March 8, 1976, should be undertaken after the hearings.

It appears at this juncture that these regulations are deficient in various respects. Comments on them are due May 9 , and will be filed on or before that date. We hereby incorporate our comments on them by reference here as an addendum to these comments, and will provide a copy for the record at the same time as 
we respond to the Federal Register notice requesting public comments on them.

\section{Merits}

In the DEIS there appears at page 12 a statement indicating that it was assumed for purposes of the DEIS that the term "maximum productivity," which is part of the definition of optimum sustainable population (hereinafter, OSP) contained in the MMPA, is attained "when a marine mammal population exhibits the greatest annual increase in numbers of individual animals...." This assumption appears to be invalid because it violates one of the criteria set forth on pages 14 and 15, which the DEIS cites as factors to be considered in determining whether a species is at OSP. The specific factor referred to is the last one, which is to the effect that high pregnancy rates suggest that a population is below OSP. At the very least, this apparent inconsistency renders suspect the assumption noted, and necessitates a discussion of the factors considered in reaching that assumption.

It also appears from the discussion in the DEIS of OSP and maximum productivity that insufficient consideration was given to the additional requirement in the definition in the Act that the health of the ecosystem must be maintained. Indeed, the assumption that greatest annual increase in numbers of animals is equated with maximum productivity seems contrary to the requirement of a healthy ecosystem. Because the animal population is a part of the 
ecosystem, and because high pregnancy rates suggest that the population is under stress and, thus, not "healthy," the assumption seems to violate this concept.

In addition, it is not clear from the DEIS what factors were considered when the conclusion was reached that any given population is at OSP. For example, it does not appear that taking incidental to fishing operations, or by natives, or by all foreign countries (Canadian taking seems to have been totally ignored) was considered for each species. It also is not clear that sufficient consideration was given, in each instance, to how many animals would be wounded and their survival rates, and how many others would not be retrieved after being mortally wounded. As we read the Act, factors such as these must be considered for each animal population before a conclusion may be reached that the population is at OSP and that a proposed level of taking will not put the population below OSP. The only way that this requirement can be shown to have been met is by a systematic discussion of each such factor for each population. If it is believed that certain factors do not affect the particular population, that hypothesis must be noted and supported. Proceeding in any other fashion will not establish that the requirements of the MMPA have been met and there will be danger that present take will be underestimated, with the result that future permitted take may be too high to maintain the population at OSP. 
We also would recommend that consideration be given to each of the factors listed on pages 14 and 15 of the DEIS. The DEIS recognizes that these are the factors which indicate whether or not a population is at OSP and each must be considered. If little or nothing is known about certain of the factors for any given population, that, too, should be noted so that consideration can be given to the level of knowledge available on any given species. Such a systematic approach will enable the decision-maker to address the Congressional finding noted in section 2(3) of the Act, that "there is inadequate knowledge of the ecology and population dynamics of such marine mammals and of the factors which bear upon their ability to reproduce themselves successfully."

It also appears that the term "take" has been used in a more restrictive sense in the DEIS than it is in the Act. In the Act the term includes the concept of harassment, attempted hunting, and capturing as well as killing of animals. Yet the DEIS does not seem to consider such actions when making an assessment of the health of the population, or of the factors affecting the ability of a population to attain and remain at OSP. The primary, if not the only, factor which appears to have been considered is retrieved takings, i.e., kills.

For at least two of the populations, it would appear that a discussion of the accessibility of adult males to breeding females would be a valuable undertaking. Because of the low 
numbers of Beluga Whale and Polar Bear relative to the extent of the range over which they are distributed, a discussion of this factor would seem warranted prior to making a determination that their populations are at OSP and to waive the moratorium for these species.

Other considerations do not seem to support a change in the status of the Polar Bear, at least with regard to renewed hunting. The intense international effort underway to census and protect Polar Bears, their scarcity, the fact that many nations have a closed season on the bears, and the intense hunting pressure that is likely to develop for this most universally prized hunting trophy should the season be opened, as well as the potential for poachers if a market is established, require a far greater showing than Alaska has made to date to justify any waiver of the moratorium on this animal.

Further, the U. S. has signed the Nov. 15, 1973 Agreement on Conservation of Polar Bears which does not expressly provide for sport hunting by non-natives (at least with snowmobiles); ratification of this international agreement currently is before the Senate.

Another factor which has great potential for affecting most of the species under consideration, but which was only mentioned in the DEIS, is the possibility that catastrophic oil spills will adversely affect these populations. Although mention was 
made that this is a possibility, it was suggested that the primary effect would relate to the food sources of the species. No mention was made of the possibility for, or the conceivable extent of, adverse effects for animals actually caught in such a spill. Neither was any attempt made at suggesting the extent of the effects of such spills on any particular population, nor was any attempt made to assess the cumulative effect such a spill might have on species which depend on the same, or closely related, food chains. While it is recognized that at this time such exercises can only be engaged in through speculation and that they are difficult to undertake, we believe that they warrant greater consideration than was given them. Finally, no suggestion was offered as to what contingency plans have been considered and adopted by the state of Alaska with regard to marine mammals in the event that such spills do occur. The issue is a very real one since tankers carrying oil from the Trans-Alaska Pipeline and off-shore coastal drilling for oil in the Gulf of Alaska will become realities in the near future.

Because the waiver, if one is granted, will be in effect to the limits of the State's jurisdiction, consideration should have been given to what effect, if any, will result from a change in the jurisdictional limit of the United States as envisioned in legislation now under consideration in both houses of Congress extending U. S. territorial waters to the 200-mile limit. 
While it is not clear that it was so treated in the DEIS, it is our position, supported by the language of the Act, that exploitation of marine mammals by Indians and Eskimos is a consideration distinctly secondary to the welfare of the various species. The Act also recognizes that there is a considerable difference between subsistence takings and takings for materials for cottage industries by natives on the one hand, and commercial exploitation on the other, the latter activity having far greater potential for resulting in adverse consequences for population levels. Consequently, while economic considerations for both natives and (to an even lesser extent) non-natives are germane under both NEPA and the MMPA, the primary objective under the MMPA is the health and stability of the marine ecosystem and preservation of viable stocks of the animals.

Several additional points should be made with regard to natives. First, there is sufficient authority under the Act for federal authorities to deal with certain of the situations cited in the DEIS to show inequities and inconsistencies under the Act. One such situation is that noted in the DEIS regarding a group of natives being brought together in what appears to be a commercial setting to "mass" produce products in the nature of cottage industries products (p. 121). From the information given, this activity does not appear to be in keeping with the - provisions of the MMPA, and should be amenable to rectification 
under federal regulations. Another such situation is that cited on page 131 of the DEIS, where it is suggested that wasteful practices of natives could be dealt with better through state management. Again, the situation related should be remediable through federal regulation aimed at preventing such wasteful practices. It also should be noted that any loss of income experienced by natives or Indians as a result of the provisions of the Act can be dealt with through alternative means, and should not, and cannot, under the MMPA be permitted to take precedence over consideration of the welfare of marine mammals and the marine ecosystem. In summary, the DEIS is not persuasive on the points that the native exemption currently in effect under the Act has or will lead to excessive take so long as the commercial market is strictly limited, or that the state will be able to enforce restrictions on subsistence takings by natives under any circumstances more effectively than is now done.

There are other concerns which we have with the proposed action which were not dealt with in the DEIS. The first of these is our concern over the vulnerability of the Alaska Department of Fish and Game to political pressure from hunters and commercial guides and fishermen in the state. This potential hazard is illustrated by the recent efforts of the state to eradicate wolves in certain areas, based on fears of hunters that moose numbers were being reduced by wolves to the detriment of the hunters. Such efforts were undertaken in spite of the 
evidence that wolves keep moose populations balanced, and that it was weather and hunting that lowered the moose population in the first instance. The point is further illustrated by the posture taken in the DEIS at pages 143-4 that marine mammals are endangering potential for increased catches of fish because of the amount of fish it is estimated that they consume, tables we believe scientifically questionable to say the least. Similarly, as noted on page 132 and elsewhere, there is considerable concern over the loss that fishermen experience when marine mammals interfere with fishing gear, and we are not convinced the ADF\&G can resist "control" pressures even if it wished to do so.

A very closely related concern of ours is that the funding level for the state program for protection of marine mammals may not be adequate and we believe that information should be provided on this point. Even if the level of funding is adequate, the source of the funds may present a potential conflict which will be detrimental to marine mammals. If these funds come entirely or largely from hunting and commercial harvesting activities, the state program may be subject and responsive to pressures which are not in the best interests of the marine mammal and which may result in actions which conflict with the Act. In short, because the protection of the marine ecosystem transcends the boundaries and economic interests which may be unique to the particular state, there must be a federal program of surveillance even in the event of any waiver. 
However, if the DEIS is any indication of the interest of the federal officials charged with responsibility for enforcement of the Act, we have concerns for such a monitoring program. We make this statement because it appears from the DEIS that federal officials are anxious to "rid" themselves of the responsibility and expense of administering the Act. In considering each of the alternatives but one (E, p. 138), there seems to be a tacit premise that a federal program is more costly and less efficient than a similar state program. While this may in fact be the case, there is no information in the DEIS itself from which such a conclusion can be drawn.

As a final matter, we believe that the DEIS should include a section on how the situation in Alaska has changed since passage of the MMPA with regard to these marine mammals so as to warrant the proposed waiver. It is not yet clear that the populations have changed so much, or the management philosophy of the state has been altered to the extent that the waiver under consideration should be approved. In short, much of the data relied on seems out of date or of unreliable nature.

We also note with great concern the publication in the Federal Register dated April 5, 1976, at pages 14372 and 14373, of the final decision on the question of waiver of the moratorium for Pacific Walrus. The waiver is now in effect, in spite of the absence of any finding by the Director of the Fish and Wildife Service that the laws and regulations of the State of 
Alaska are consistent with the MMPA and the federal regulations promulgated under the MMPA. Such a finding is required by Section $109(\mathrm{a})(2)$ and (3), which the Director recognized in his earlier publication in the Federal Register regarding this waiver. In the December 24, 1975, Federal Register at page 59461 appears the following language, "A final notice of waiver will be published in the Federal Register upon my approval of the revised state laws and regulations." (Emphasis added.) Yet all that appeared in the final notice on April 5, 1976, was a certification that the revised management program of the state was in compliance, and the finding noted in $\$ 18.58,50$ C.F.R., that Alaska's laws and regulations had been approved by the Director. We know of no amendments to Alaska's laws, nor of any changes in its regulations. No revisions or changes were referenced in the final notice, either. The final EIS must deal with these matters, and publication must be made in the Federal Register of the changes which have occurred since the December 24, 1975, notice.

In summary, we believe that much information has yet to be provided and developed through the hearing process and otherwise before the Draft Statement can be converted into an adequate final statement. Much of the language in the DEIS

* The DEIS admits as much by revealing differences between the federal and state agencies involved on such basic questions as population levels (see Belugas (p. 119) and Harbor Seals (p. 115)) We are particularly interested to hear the comments of the Marine Mammal Commission. 
is conclusory and unsupported by facts anywhere contained in the document. Other conclusions are based on premises that do not appear to have been adequately discussed or considered. Much of the information seems dated and apparently other data simply has not yet been gathered. Environmental values and consequences of alternative courses of action have not been meaningfully dealt with and no attempt has been made at quantifying them so that they can be compared. Economic considerations of "harvest" and "control" have been overstressed., Until these and the other defects noted above are remedied, we do not believe that a waiver of the moratorium and/or delegation of management authority to Alaska for any of the species is appropriate.

Notwithstanding the above-mentioned inadequacies of the present statement, we intend to participate in the hearing process with open minds. However, because of the apparent paucity of information developed at this juncture on certain species, and because of the seemingly low numbers of other species, it appears that if it is possible to take any action on the proposed waiver, it may be limited to a selective waiver of the moratorium and a partial transfer of management authority to the state. Such selective waiver and partial transfer could not be undertaken, however, until the laws and regulations of the state have been amended to be consistent with the MMPA and federal regulations. We make this statement because history has shown that commercial exploitation has great potential for decimation of species. The heedless eradication of the now extinct Stellers' Sea Cow from Alaskan waters should serve as a warning of what could be the 
result of a premature waiver of the prohibition on taking.

Indeed the specter of this type of unthinking action was unquestionably a moving force which resulted in passage of the MMPA with which we are all dealing in this process. As was noted by the MMPA's floor manager and House sponsor, Representative John Dingell, during the course of debate on the floor (December 6, 1971, Cong. Rec. H-11847):

"As a practical matter, the legislation before the House today will provide a de facto moratorium for many years with respect to many of the animals which the bill covers. This conclusion follows the provisions of the bill requiring adequate information before a permit can be issued, and the essential lack of hard data on almost every one of the animals covered by the bill." (Emphasis added.)

And as the House Report (p. 15) makes clear, the legislative history of the MMPA reflects a strong concern over depletion of many species of marine mammals:

"In the teeth of this lack of knowledge of specific causes, and of the certain knowledge that these animals are almost all threatened in some way, it seems elementary common sense to the Committee that legislation should be adopted to require that we act conservatively-that no steps should be taken regarding these animals that might prove to be adverse or even irreversible in their effects until more is known." I/

1/ Report of the House Committee on Merchant Marine and Fisheries on H.R. 10420, 92d Cong., lst Sess., Report No. 92-707. (Emphasis added.) 
The Senate Report (pp. 1-2) states that:

". . man's dealings with marine mammals have

in many areas resulted in over-utilization

of the precious natural resource." $1 /$

Our participation in the various proceedings leading up to a decision on the subject matter of this DEIS will be governed by knowledge of the above strongly expressed Congressional sentiment, and we trust that yours will be too.

Sincerely,

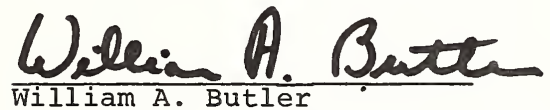
William A. Butler Washington Counsel Environmental Defense Fund

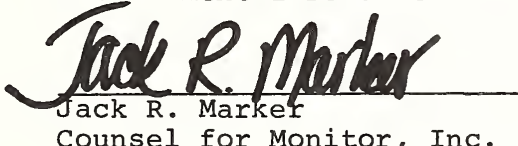

Counsel for Monitor, Inc.

April 19, 1976

1/ Report of the Senate Committee on Commerce on S. 2871, 92d Cong. 2d Sess., Report No. 92-868 (hereinafter the "Senate Report"). 


\section{ADDENDUM}

The following groups participating in the Monitor Consortium join in the preceding comments:

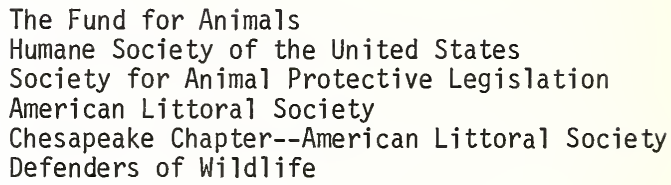

A supplemental submission noting additional groups which wish to join in these comments will follow. 
Environmental Defense Fund:

\section{Comment:}

In the DEIS there appears at page 12 a statement indicating that it was assumed for purposes of the DEIS that the term "maximum productivity", which is part of the definition of optimum sustainable population (hereinafter, OSP) contained in the MMPA, is attained "when a marine mammal population exhibits the greatest annual increase in numbers of individual animals..." This assumption appears to be invalid because it violates one of the criteria in determining whether a species is at OSP. The specific factor referred to is the last one, which is to the effect that high pregnancy rates suggest that a population is below OSP. At the very least, this apparent inconsistency renders suspect the assumption noted, and necessitates a discussion of the factors considered in reaching that assumption.

\section{Response:}

The maximum productivity is attained when a marine mammal population exhibits the greatest annual increase in numbers of individuals. Maximum productivity does not relate directly to the pregnancy rate, but to the number of animals reproduced annually. For example, a population of three animals ( 1 male, 2 females) of which both females were pregnant, will have a reproductive rate of $662 / 3$ percent, but will increase the population by only 2 animals whereas a population with 50 males, and 50 females of which 20 females were pregnant, would have a reproduction rate of 20 percent but would increase the population by 20 animals. This demonstrates that even with a low reproductive rate, maximum productivity is related more to the number of animals in the population than to the rate of reproduction.

\section{Comment:}

It also appears from the discussion in the DEIS of OSP and maximum productivity that insufficient consideration was given to the additional requirement in the definition of the Act that the health of the ecosystem must be maintained. Indeed, the assumption that greatest annual increase in numbers of animals is equated with maximum productivity seems contrary to the requirement of a healthy ecosystem. Because the animal population is a part of the ecosystem, and because high pregnancy rates suggest that the population is under stress and, thus, not "healthy," the assumption seems to violate this concept.

\section{Response:}

A healthy ecosystem does not necessarily equate to a healthy marine mammal population. Populations are continually under stress from various factors including disease, predation, and famine. High pregnancy rates are indicative of a population recuperating from high levels of mortality either natural or induced. Once these rates level off or decrease, the population is assumed to be at the carrying capacity of the environment and would be a factor is assuring the health of the ecosystem. 
In addition, it is not clear from the DEIS what factors were considered when the conclusion was reached that any given population is at OSP. For example, it does not appear that taking incidental to fishing operations, or by natives, or by all foreign countries (Canadian taking seems to have been totally ignored) was considered for each species. It also is not clear that sufficient consideration was given, in each instance, to how many animals would be wounded and their survival rates, and how many others would not be retrieved after being mortally wounded. As we read the Act, factors such as these must be considered for each animal population before a conclusion may be reached that the population is at OSP and that a proposed level of taking will not put the population below OSP. The only way that this requirement can be shown to have been met is by a systematic discussion of each such factor for each population. If it is believed that certain factors do not affect the particular population, that hypothesis must be noted and supported. Proceeding in any other fashion will not establish that the requirements of the MMPA have been met and there will be danger that present take will be underestimated with the result that future permitted take may be too high to maintain the population at 0 SP.

\section{Response:}

The indices used in determining the OSP for each population were discussed in section II.C. of the DEIS and FEIS. We believe sufficient discussion of each species have been given in the EIS as to its OSP level. Mortality levels incidental to foreign fishing operations were discussed on pages 101-102 and in table 5. Additional information on Native take is provided in the FEIS as noted in response to similar concerns raised in the Nunam Kitlutsisti letter.

\section{Comment:}

We also would recommend that consideration be given to each of the factors 1isted on pages 14 and 15 of the DEIS. The DEIS recognizes that these are the factors which indicate whether or not a population is at OSP and each must be considered. If little or nothing is known about certain of the factors for any given population, that, too, should be noted so that consideration can be given to the level of knowledge available on any given species. Such a systematic approach will enable the decision-maker to address the Congressional finding noted in Section 2(3) of the Act, that "there is inadequate knowledge of the ecology and population dynamics of such marine mammals and of the factors which bear upon their ability to reproduce themselves successfully."

\section{Response:}

During the hearing process, testimony was given regarding the appropriateness of the indices listed on pages 14 and 15 of the DEIS. The hearings revealed that the list was confusing to the average reader, since the applicability of a particular factor varies considerably depending on the species. Therefore, the general list has been omitted from the FEIS. In the discussion of the OSP for each species, in section II.C. of the FEIS, particular indices of abundance are referred to when appropriate. The FEIS discussion of OSP also includes pertinent indices relied upon by the ALJ in his recommended decision. 
It also appears that the term "take" has been used in a more restrictive sense in the DEIS than it is in the Act. In the Act the term includes the concept of harassment, attempted hunting, and capturing as well as killing of animals. vet the DEIS does not seem to consider such actions when making an assessment of the health of the population, or of the factors affecting the ability of a population to attain and remain at OSP. The primary, if not the only, factor which appears to have been considered is retrieved takings, i.e., kills.

\section{Response:}

The term "take" has been used as defined in the Act, the only concept not incorporated being harassment. The DEIS has considered and incorporated live capture, scientific display, hunting loss, and incidental take.

\section{Comment:}

For at least two of the populations, it would appear that a discussion of the accessibility of adult males to breeding females would be a valuable undertaking. Because of the low numbers of Beluga Whale and Polar Bear relative to the extent of the range over which they are distributed, a discussion of this factor would seem warranted prior to making a determination that their populations are at OSP and to waive the moratorium for these species.

\section{Response:}

As stated on page 73, volume 1, belugas are gregarious and travel in pods of several individuals to groups of hundreds. We doubt, therefore, that they have any trouble locating each other. Animals such as polar bears have, through inherited characteristics, long since solved the problem of locating members of the opposite sex during the breeding season. Since 19 percent of the population is made up of females with young and with delayed implantation (since females reproduce only every third year), we do not anticipate any problems with the low rate of take proposed.

\section{Comment:}

Other considerations do not seem to support a change in the status of the Polar Bear, at least with regard to renewed hunting. The intense international effort underway to census and protect Polar Bears, their scarcity, the fact that many nations have a closed season on the bears, and the intense hunting pressure that is likely to develop for this most universally prized hunting trophy should the season be opened, as well as the potential for poachers if a market is established, require a far greater showing than Alaska has made to date to justify any waiver of the moratorium on this animal. Further, the U.S. has sianed the Nov. 15, 1973 Agreement on Conservation of Polar Bears which does not expressly provide for sport hunting by non-Natives (at least with snowmobiles); ratification of this international agreement currentiy is before the Senate. 
Response:

The Agreement on Conservation of Polar Bears does not exclude sport hunting by non-Natives. The drafters of this treaty considered sport hunting and the use of snowmobiles as traditional means addressed in Article III 1. (d) and (e). Article IV only prohibits the use of aircraft and large motorized vessels for the purpose of taking polar bears.

Comment:

Another factor which has great potential for affecting most of the species under consideration, but which was only mentioned in the DEIS, is the possibility that catastrophic oil spills will adversely affect these populations. Although mention was made that this is a possibility, it was suggested that the primary effect would relate to the food sources of the species. No mention was made of the possibility for, or the conceivable extent of, adverse effects for animals actually caught in such a spill. Neither was any attempt made at suggesting the extent of the effects of such spills on any particular population, nor was any attempt made to assess the cumulative effect such a spill might have on species which depend on the same, or closely related, food chains. While it is recognized that at this time such exercises can only be engaged in through speculation and that they are difficult to undertake, we believe that they warrant greater consideration than was given them. Finally, no suggestion was offered as to what contingency plans have been considered and adopted by the State of Alaska with regard to marine mammals in the event that such spills do occur. The issue is a very real one since tankers carrying oil from the Trans-Alaska Pipeline and off-shore coastal drilling for oil in the Gulf of Alaska will become realities in the near future.

\section{Response:}

The issue of oil spills and attendant environmental damage is discussed in the response to a similar comment in the Nunam Kitlutsisti letter. In accordance with the terms of the implemented waiver, if at some time losses were to occur, then under correct wildlife management practices the State would take appropriate measures to assure continuation of a viable population stock at OSP levels.

Comment:

Because the waiver, if one is granted, will be in effect to the limits of the State's jurisdiction, consideration should have been given to what effect, if any, will result from a change in the jurisdictional limit of the United States as envisioned in legislation now under consideration in both houses of Congress extending U.S. territorial waters to the 200-mile limit. 
The Marine Mammal Protection Act covers citizens of the U.S. whether within or without the territorial jurisdiction of the U.S. except when a U.S. citizen is within the recognized territorial jurisdiction of another nation. The 1976 amendment to the Act extended its prohibitions to all vessels and persons, of whatever nationality within the U.S. fishery conservation zone, the outer limit of which is up to 200 miles from the U.S. coast. Testimony at the formal administrative hearings on this proposal indicates that this change in the law will have negligible impact on takings by foreign sealing fleets.

\section{Comment:}

Several additional points should be made with regard to natives. First, there is sufficient authority under the Act for federal authorities to deal with certain of the situations cited in the DEIS to show inequities and inconsistencies under the Act. One such situation is that noted in the DEIS regarding a group of natives being brought together in what appears to be a commercial setting to "mass" produce products in the nature of cottage industries products (p. 121). From the information given, this activity does not appear to be in keeping with the provisions of the MMPA, and should be amenable to rectification under federal regulations. Another such situation is that cited on page 131 of the DEIS, where it is suggested that wasteful practices of natives could be dealt with better through state management. Again, the situation related should be remediable through federal regulation aimed at preventing such wasteful practices. It also should be noted that any loss of income experienced by natives or Indians as a result of the provisions of the Act can be dealt with through alternative means, and should not, and cannot, under the MMPA be permitted to take precedence over consideration of the welfare of marine mammals and the marine ecosystem. In summary, the DEIS is not persuasive on the points that the native exemption currently in effect under the Act has or will lead to excessive take so long as the commercial market is strictly limited, or that the state will be able to enforce restrictions on subsistence takings by natives under any circumstances more effectively than is now done.

\section{Response:}

The Marine Mammal Protection Act specifically exempted Alaskan Natives if such taking is for subsistence purposes or is done for creating and selling authentic articles of handicraft and clothing and in each case is not accomplished in a wasteful manner. Although Federal regulations could control certain wasteful practices and other violations of the Act, enforcement of such violations would be better handled under a State management program because, as explained in the FEIS, Federal enforcement under the moratorium has not been completely successful.

Comment:

A very closely related concern of ours is that the funding level for the state program for protection of marine mammals may not be adequate and we believe that information should be provided on this point. Even if the level of funding is adequate, the source of the funds may present a potential conflict which will be detrimental to marine mammals. If these funds come entirely or largely from hunting and commercial harvesting activities, the state program may be subject and responsive to pressures which are not in the best interests 
of the marine mammals and which may result in actions which conflict with the Act. In short, because the protection of the marine ecosystem transcends the boundaries and economic interests which may be unique to the particular state, there must be a federal program of surveillance even in the event of any waiver.

\section{Response:}

Both the Federal Government and the State of Alaska have research programs on the marine mammals of Alaska. The State program was discussed in appendix D, vol.II. Section 109 of the Act, 50CFR \$216.106 and \$18.56 provide for continuing Federal monitoring of the State program after a return of management and section 109(b) authorizes grants to states which are administering programs following such a return of management.

\section{Comment:}

However, if the DEIS is any indication of the interest of the federal officials charged with responsibility for enforcement of the Act, we have concerns for such a monitoring program. We make this statement because it appears from the DEIS that federal officials are anxious to "rid" themselves of the responsibility and expense of administering the Act. In considering each of the alternatives but one (E, p. 138), there seems to be a tacit premise that a federal program is more costly and less efficient than a similar state program. While this may in fact be the case, there is no information in the DEIS itself from which such a conclusion can be drawn.

\section{Response:}

As discussed at the hearing, although Federal officials are not anxious to "rid" themselves of the responsibility to administer the Act, enforcement efforts in the State have been limited by budgetary constraints. It is contended that the State law enforcement program would be more effective because of its size and its closeness to the residents of the State. It is believed that compliance by the residents would be more easily achieved with a State management program than with a Federal program.

\section{Comment:}

As a final matter, we believe that the DEIS should include a section on how the situation in Alaska has changed since passage of the MMPA with regard to these marine mammals so as to warrant the proposed waiver. It is not yet clear that the populations have changed so much, or the management philosophy of the State has been altered to the extend that the waiver under

consideration should be approved. In short, much of the data relied on seems out of date or of unreliable nature.

\section{Response:}

New information introduced at the $1976 \mathrm{ALJ}$ hearing has been incorporated into the FEIS. 
We also note with great concern the publication in the Federal Register dated April 5, 1976, at pages 14372 and 14373, of the final decision on the question of waiver of the moratorium for Pacific walrus. The waiver is now in effect, in spite of the absence of any finding by the Director of the Fish and Wildlife Service that the laws and regulations of the State of Alaska are consistent with the MMPA and the federal regulations promulgated under the MMPA. Such a finding is required by Section $109(a)(2)$ and (3), which the Director recognized in his earlier publication in the Federal Register regarding this waiver. In the December 24, 1975, Federal Register at page 59461 appears the following language, "A final notice of waiver will be published in the Federal Register upon my approval of the revised state laws and regulations." (Emphasis added). Yet all that appeared in the final notice on April 5, 1976, was a certification that the revised management program of the state was in compliance, and the finding noted in $\$ 18.68,50$ C.F.R., that Alaska's laws and regulations had been approved by the Director. We know of no amendments to Alaska's laws, nor of any changes in its regulations. No revisions or changes were referenced in the final notice, either. The final EIS must deal with these matters, and publication must be made in the Federal Register of the changes which have occurred since the December 24, 1975, notice.

\section{Response:}

In a decision published in the Federal Register on December 24, 1975 (40 FR 59439), the Director determined that the moratorium should be waived on the taking of the Pacific walrus. That determination was made contingent upon the Director's approval of Alaska's management program including its laws and regulations revised in accordance with the Director's decision and those portions of the administrative law judge's recommendations that were accepted by the Director.

On February 23, 1976, the State of Alaska submitted proposed regulations revised in accordance with the Director's decision and on Apri1 5, 1976, the Director published a notice in the Federal Register (41 FR 14372) of his final approval of the State management program for Pacific walrus. The notice certified that the management program complied with the Director's decision. 


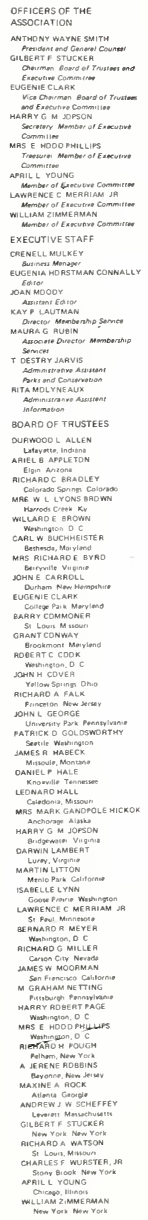

Lynn A. Greenwalt

Director

United States Fish and Wildlife Service

U. S. Department of the Interior

Washington, D.C. 20240

Mr. Robert W. Schoning

Director

National Marine Fisheries Service

330 Whitehaven Street, NW

Washington, D.C. 20235

Dear Mr. Schoning and Mr. Greenwalt:

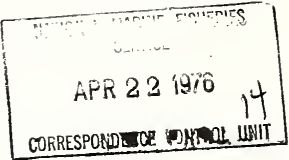

The National Parks and Conservation Association, 1701

18th Street, NW, Washington, D.C., has, for over 50 years, been concerned with the protection of all of the nation's natural resources, including wildlife. Therefore, we wish to submit the following comments for the record on the Draft Environmental Impact statement on the Consideration of a Waiver of the Mordtorium and Return of Management of Certain Marine Mammals to the state of Alaska.

The Marine Mammal Protection Act was enacted in 1972 to restore and stabilize populations of marine mammals. The State of Alaska has stated that the Moratorium should be lifted because the populations of Northern sea lions, harbor seals, ringed seals, ribbon seals, bearded seals, and beluga whales have stabilized. The State of Alaska also feels that the continuation of the moratorium could hurt this resource due to lack of research, and could result in a sharp decline in population when the various species involved reach their optimum sustainable population.

From a socio-economic standpoint, the State of Alaska feels that the Alaskan native will suffer economic hardship if the moratorium continues because they are no longer able to sell marine mammal products to anyone other than Alaskan Natives unless made into a native handicraft.

The National Parks and Conservation Association feels that a lifting of the moratorium would not be in the best interest of the marine mammals affected by this waiver and that a continuation of the moratorium would not place any hardship on Alaskan natives. Furthermore, the DEIS fails to sufficiently comply with the requirements of the National Environmental Policy Act (NEPA).

National Parks \& Conservation Association, 1701 Eighteenth Street, N.W., Washington. D.C. 20009 telephone (202) 265-2717 
Lynn A, Greenwalt

Robert $W$ : Schoning

April 19, 1976

page two

The former governor of Alaska, William A. Egan, wrote to the Commerce Department in the beginning of 1973 to ask for a waiver of the moratorium in the State of Alaska. Included with this letter were status reports and marine mammal regulations proposed by the State of Alaska. Since that time, very little new data has been submitted on the status of these animals and the regulations have not been sufficiently changed to meet with the requirements set forth in the Marine Mammal Protection Act. More time, and a great deal more research is needed before the impacts can be fully understood. The DEIS has, in fact, stated that research and data collection has declined since the moratorium began. Appendix $D$ of the DEIS reports that no funds were used in FY 1972 for research and data collection on these mammals. Perhaps this is an indication of future actions by the state of Alaska. What funding is proposed by the State of Alaska and where will these funds be spent? If the moratorium is continued, we would hope that the Federal Government will see to it that funds are provided for this important activity and that the issuance of permits for scientific research is handled in a more expediant manner.

Research on animals listed under the Endangered Species Act has not been hindered by the regulations governing these animals and we hope that research on marine mammals can be handled in the same manner.

The original regulations proposed by the State of Alaska for the management of Marine Mammals appears to be indicative of the attitude of the State of Alaska towards these mammals -a deep concern for the economic gains resulting from harvest of these marine mammals rather than a concern for their protection. For example, the State of Alaska has proposed that in many areas, there be no bag limit and no closed season on the taking of the sea lion. In certain units a "no bag limit" was also listed for harbor, spotted, ringed, bearded and ribbon seals. In Appendix $\mathrm{H}$, Alaska Administrative Code Title 5, Article 3 , 5 AAC $81.100(5)$ nets are listed as an acceptable means of taking of marine mammals. Seals were not listed as an exception to this regulation. Article 5 AAC 81.200 leads one to believe that there are no restrictions on the purchase and sale of marine mammals other than the polar bear. Section 5 AAC 81,350 lists a "no closed season" for the hunting of Sea lions and beluga and Seal in certain areas. In general, the proposed regulations leave the issuing of permits up to the discretion of the commissioner with too much latitude given for the numbers to be taken and the seasons in which 
Lynn A.e Greenwalt

Robert $W$. Schoning

April 19, 1976

page three

they are allowed to be hunted. These proposed regulations do not comply with the requirements set forth by the Marine Mammal Protection Act of 1972 .

The DEIS does not show that the species involved in this waiver have reached their optimum sustainable population which is the goal of the Act. Maximum productivity does not necessarily mean that the ecosystem as a whole. is in a healthy state, which is one of the criteria set forth in the Act. The rate of incidental taking and taking by foreign countries was not considered in the DEIS and this has an important bearing on the population size of these animals. Tabulations for all takings must be considered before a waiver of the moratorium can be estabiished.

No discussion was given in the DEIS on occurrences other than actual taking which might affect the populations of marine mammals. For example, what affects would oil spills have on these various species? Also, what affect will the proposed 200-mile limit have on the State of Alaska's jurisdiction?

NPCA feels that because of the deficiencies in the DEIS noted above, the State of Alaska's regulations do not meet the standards of the Marine Mammal protection Act and therefore a waiver of the moratorium should not be granted.

NPCA feels that pressure from sport nunting and commercial fishing operations could possibly influence the State of Alaska on propoer management of marine mammals. With management of these animals under the jurisdiction of the Federal Government, the liklihood of this happening is much more improbable.

The socio-economic impact of the moratorium, if given time would be in the best interest of the Alaskan native. The Alaskan native, under the moratorium, is allowed to take marine mammals whereas commerical operations and non-natives are no longer allowed to hunt these animals. With a waiver of the moratorium, the catch of the Alaskan native would be far outwighed by the catch of these non-natives, thus creating a competition for this resource.

We feel that the "No action" alternative, at present, seems to be in the best interest of the Alaskan native and 
Lynn A. Greenwalt

Robert W. Schoning

April 19, 1976

page four

of the marine mammals involved. In time, when more study has been given to the effects of the moratorium, perhaps a waiver would be justified. However, at present, the state of Alaska has not shown sufficient evidence that it is in a position to resume the management of these species.

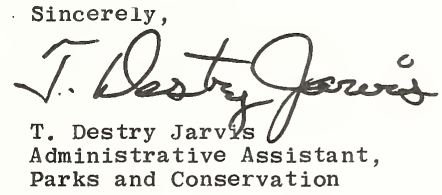

$\mathrm{TDJ} / 1 \mathrm{c}$ 
National Parks and Conservation Association

Comment:

The former governor of Alaska, William A. Egan, wrote to the Commerce Department in the beginning of 1973 to ask for a waiver of the moratorium in the State of Alaska. Included with this letter were status reports and marine mammal regulations proposed by the State of Alaska. Since that time, very little new data has been submitted on the status of these animals and the regulations have not been sufficiently changed to meet with the requirements set forth in the Marine Mammal Protection Act. More time, and a great deal more research is needed before the impacts can be fully understood. The DEIS has, in fact, stated that research and data collection has declined since the moratorium began. Appendix D of the DEIS reports that no funds were used in FY 1972 for research and data collection on these mammals. Perhaps this is an indication of future actions by the State of Alaska. What funding is proposed by the State of Alaska and where will these funds be spent? If the moratorium is continued, we would hope that the Federal Government will see to it that funds are provided for this important activity and that the issuance of permits for scientific research is handled in a more expedient manner.

\section{Pesponse:}

Some of the material used in writing the DEIS was submitted by the State in 1973 in compliance with section 109 of the Act. Additional new data were used as they became available and were so referenced in the DEIS. Still more data were submitted at the hearing and are included in the FEIS if appropriate. The State of Alaska has had a continuous research program on marine mammals for many years. Although consideration was given to ending the research program upon enactment of the MMPA, the State instead decided to ask for a waiver of the moratorium and a return of management and therefore to continue with its ongoing research. The DEIS, volume II, discusses the funding of the State research program and is incorporated in the FEIS, vol. II.

Comment:

The original regulations proposed by the State of Alaska for the management of Marine Mammals appear to be indicative of the attitude of the State of Alaska towards these mammals--a deep concern for the economic gains resulting from harvest of these marine mammals rather than a concern for their protection. For example, the State of Alaska has proposed that in many areas, there be no bag limit and no closed season on the taking of the sea lion. In certain units a "no bag limit" was also listed for harbor, spotted, ringed, bearded and ribbon seals. In Appendix H. Alaska Administrative Code Title 5, Article 3, 5 AAC $81.100(5)$ nets are listed as an acceptable means of taking marine mammals. Seals were not listed as an exception to this regulation. Article 5 AAC 81.200 leads one to believe that there are no restrictions on the purchase and sale of marine mammals other than the polar bear. Section 5 AAC 81.350 lists a "no closed season" for the hunting of sea lions and beluga and seal in certain areas. In general, the proposed regulations leave the issuing of permits up to the discretion of the commissioner with too much latitude given for the numbers to be taken and the seasons in which 
they are allowed to be hunted. These proposed regulations do not comply with the requirements set forth by the Marine Mammal Protection Act of 1972 .

\section{Response:}

The Marine Mammal Protection Act does not address the issues mentioned. Closed seasons and limited take are management concepts designed to protect populations during critical periods or to lower hunting pressure. Closed seasons may be initiated later if necessary; however, during the initial stage hunting pressure appears to be low and closed seasons are normally unnecessary. Although there are no bag limits and no closed seasons for certain animals, annual limits on taking have been established, as discussed in the DEIS and FEIS, which are designed to keep the population stocks at OSP levels. Nets are not considered an inhumane method of take.

\section{Comment:}

The DEIS does not show that the species involved in this waiver have reached their optimum sustainable population which is the goal of the Act. Maximum productivity does not necessarily mean that the ecosystem as a whole is in a healthy state, which is one of the criteria set forth in the Act. The rate of incidental taking and taking by foreign countries was not considered in the DEIS and this has an important bearing on the population size of these animals. Tabulations for all takings must be considered before a waiver of the moratorium can be established.

\section{Response:}

A11 takings have been considered in determining the extent of the waiver and have been discussed in the DEIS. Those takings such as foreign incidental take were subtracted from the total allowable take level before determining the amount of take that could be returned to the State. The Act does not correlate maximum productivity with the health of the ecosystem nor is it a criterion of the Act that "the ecosystem as a whole is in a healthy state." As the Act reads:"The term 'optimum sustainable population' means with respect to any population stock, the number of animals which will result in the maximum productivity of the population or the species, keeping in mind (emphasis ours), the optimum carrying capacity of the habitat and the health of the ecosystem of which they form a consti tuent element." Maximum productivity therefore would be a factor if there was an indication that the carrying capacity of the habitat would be exceeded.

\section{Comment:}

No discussion was given in the DEIS on occurrences other than actual taking which might affect the population of marine mammals. For example, what affect would oil spills have on these various species? Also, what affect will the proposed 200-mile limit have on the State of Alaska's jurisdiction? 
Response:

$0 i 1$ spill impacts were discussed in the DEIS. The 1976 amendment to the MMPA, which provides MMPA control over taking by foreign persons within the U.S.

fishery conservation zone, will have negligible impact on the proposed action. The Federal agencies will retain authority to issue or deny permits for the taking of marine mammals by foreign fishing or sealing vessels. 


\author{
Alice Herrington \\ Chairman \\ Bernard Fensterwald, Jr. \\ Counsel \\ Jowanda Shelton \\ Washington Director
}

\author{
Director \\ National Marine Fisheries Service \\ 3300 Whitehaven Street \\ Washington, D. C. 20235
}

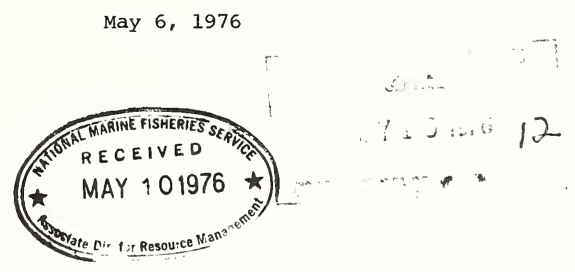

Dear Mr. Director:

Pursuant to notice given in the Federal Register on Friday, April 9, 1976 (Vol. 41, No. 70), the Committee for Humane Legislation and Friends of Animals, Inc. intend to participate in the proceedings with respect to a proposed Waiver of Moratorium Takings and Importations, and Proposed Regulations to govern such taking and importation. We intend to be present at the pre-hearing conference on May 18, 1976, and will be represented either by Mr. Bernard Fensterwald, Jr., counsel to both organizations and/or by Miss Jowanda Shelton, Director of the Washington office of the Committee for Humane Legislation. All written communications with respect to this proceeding should be addressed to Mr. Bernard Fensterwald, Jr., 910 16th Street, N. W., Washington, D. C. 20006.

We request a hearing in the Washington, D. C. area specifically, but, of course, we have no objection to additional hearings outside the Washington area.

As to issues of fact and law, we shall list as many as are obvious to us at this point. Our objections in general are similar to those voiced in previous hearings held in March and April, 1975 on delegation of authority to the state of Alaska to manage the walrus.

As to Subpart $\mathrm{H}$ : Do the proposed regulations meet the requirements of s 103 (d) of the Marine Mammal Protection Act? That section clearly and specifically requires an "on the record" agency hearing each and everytime the moratorium is to be waived with respect to a particular mammal or a particular stock of a particular mammal. It requires publication before the agency hearing of detailed statistics with respect to the mammal or population stock. Under section 216.104 of these regulations, final approval of state laws and regulations would appear to take place without a hearing of any kind. There is no indication that any hearings will be held with respect to each state application, nor is there any indication hearings will be held per species of animal or discrete stock of species of animal to be "managed," nor manner of "taking" those animals.

Although Subpart $\mathrm{H}$ is described in the Federal Register notice as "Cooperative State Federal Management System," the same notice later reads: "the state will actually manage the resource." What role will be played by the Federal Government?

Section 216.106 will contain a list of all waivers of the moratorium, and of all states which have approved programs "for public convenience and clarity," but there is no indication the public will be permitted to comment at public hearings either on the legality or wisdom of those waivers. 
Director, National Marine Fisheries Service

May 6, 1976

page 2

The U. S. owns (as a private landowner rather than as sovereign) over 90 percent of the land in Alaska. Under the new regime, does the United States abrogate its rights as landowner as well as sovereign? In case of another incident such as the recent "wolf hunt," would the United states as landowner be prevented from exerting its rights which might run contrary to the state of Alaska?

With regard to the Draft Environmental Impact statement, we question the objectivity of the Departments of Commerce and Interior; this statement seems to express few interests, views and opinions other than their own.

Under what Constitutional or Statutory authority would Alaskan officials have power over non-Alaskan citizens on the high seas?

Under the proposed regime, what is to stop a citizen of California from going into the Bering Sea, killing a hundred walrus and selling them in Vancouver or Tokyo?

Which of the nine species of marine mammals are "resident" in Alaska?

Under the proposed system of regulation of marine mamals, what is to prevent the Department of Commerce from turning over regulation of the taking of porpoise to the state of California, which contains the home port of the United States tuna fleet?

Under what Constitutional or statutory authority are the statutory rights of Indian, Aleut, or Eskimo natives (provided in 101 (b) of the Marine Mammal Protection Act) being abrogated.

The "waters off Alaska" appear to extend for several thousand miles under the proposed regime. Is there any limit as to how far they can proceed? Isn't much of this same area of high seas equally "off of" the states of washington and Oregon?

Do the Alaska regulations as to polar bear comport with the provisions of the International treaty re polar bear?

Why were the Pribilof seals not included in the nine species?

New Federal-State arrangements cannot be to the "disadvantage" of a species. Is the taking of 63,000 animals (or 77,610 animals) as compared to 23,000 a clear "disadvantage" to the animals?

It is stated (page 9 of the DEIS) that there will be no hearings on regulations applicable to "all states" as opposed to Alaska. Why? 
Director, National Marine Fisheries Service

May 6, 1976

page 3

As to Polar Bear, the State of Alaska will grant licenses and permits. How do these interact?

Do the estimated 250 polar bears include (1) those taken in self defense, (2) those taken to protect property, or (3) those taken for food? If not, what is the total estimated kill of polar bear per year? Will oil company/pipe line employees be given licenses and/or permits? Can hunters use airplanes at all and if so, for what purposes?

There are many more legal and factual questions that should be put in issue. But these are the basic foundation decisions. We reserve the right to raise additional questions at the prehearing conference May 18, 1976.

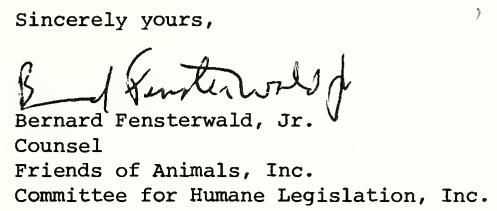


Committee for Humane Legislation, Inc.

Comment:

Under what Constitutional or Statutory authority would Alaskan officials have power over non-Alaskan citizens on the high seas?

Response:

Alaskan officials would have authority over Alaskan residents on the high seas. Those non-Alaskans hunting for marine mammals on the high seas would be in violation of the Marine Mammal Protection Act and subject to arrest thereunder unless taking in accordance with a Federal permit issued under

50 CFR $\$ 18.95(h)$ or 50 CFR $\$ 216.113(h)$. State officials are deputized by Federal authorities to enforce Federal laws and regulations in the State or on the high seas.

\section{Comment:}

Under the proposed regime, what is to stop a citizen of California from going into the Bering Sea, killing a hundred walrus and selling them in Vancouver or Tokyo?

\section{Response:}

The Marine Mammal Protection Act and regulations promulgated thereunder would prevent citizens not holding valid hunting licenses and/or permits issued by the State of Alaska or Federal agencies from hunting marine mammals.

Comment:

Which of the nine species of marine mammals are "resident" in Alaska?

Response:

All nine species can be considered as resident of the State of Alaska.

Comment:

Under the proposed system of regulation of marine mammals, what is to prevent the Department of Commerce from turning over regulation of the taking of porpoise to the State of California, which contains the home port of the United States tuna fleet?

\section{Response:}

The proposed action has nothing to do with the taking of porpoises by the U.S. tuna fleet. The Commerce Department has no plans to return management to the State of California regarding the incidental taking of porpoises. 
Comment:

Under what Constitutional or Statutory authority are the statutory rights of Indian, Aleut, or Eskimo natives (provided in 101 (b) of the Marine Mammal Brotection Act) being abrogated.

Response:

Native rights are not abrogated. The provisions of the Act do not apply to Natives taking nondepleted species for subsistence or handicraft purposes.

\section{Comment:}

The "waters off Alaska" appear to extend for several thousand miles under the proposed regime. Is there any limit as to how far they can proceed? Isn't much of this same area of high seas equally "off of" the States of Washington and Oregon?

\section{Response:}

The limits for the proposed action are discussed on pages $i i$ and 16 of volume I of the DEIS.

\section{Comment:}

Do the Alaska regulations as to polar bear comport with the provisions of the International treaty $\underline{\text { re }}$ polar bear?

\section{Response:}

Yes.

\section{Comment:}

Why were the Pribilof seals not included in the nine species?

\section{Response:}

The language of the Act and the regulations issued thereunder (39 FR 1854) exclude certain actions under international treaties. Sections 18.21 and 216.21 of the regulations state in part: "Specifically, the regulations in subpart B of this part and the provisions of the Act shall not apply to activities carried out pursuant to the Interim Convention on the Conservation of North Pacific Fur Seals signed at Washington on February 9, 1957, and the Fur Seal Act of 1966, 16 U.S.C. 1151 - 1187." 
Comment:

New Federal-State arrangements cannot be to the "disadvantage" of a species. Is the taking of 63,000 animals ( or 77,610 anima1s) as compared to 23,000 a clear "disadvantage" to the animals?

\section{Response:}

The DEIS and FEIS discuss the impact of the proposed action on each species.

\section{Comment:}

It is stated (page 9 of the DEIS) that there will be no hearings on regulations applicable to "all States" as opposed to Alaska. Why?

\section{Response:}

The regulations applicable to all States which established a new subpart $H$ in part 216, and subpart $F$ in part 18, Title 50, Code of Federal Regulations, provided standards and procedures for approving and monitoring State laws and regulations implementing waivers of the moratorium. These regulations implement section 109 of the Act, not section 103 and, as such, do not require a hearing before implementation. However, before an individual state can receive a waiver under subpart $\mathrm{H}$ or $\mathrm{F}$, there must be an opportunity for a hearing as required by section 103.

\section{Comment:}

As to Polar Bear, the State of Alaska will grant licenses and permits. How do these interact?

\section{Response:}

A11 residents and non-residents are required to obtain licenses before sport hunting is permitted. Certain species of animals require permits issued by the department or the commission before they may be legally taken.

\section{Comment:}

Do the estimated 250 polar bears include (1) those taken in self defense (2) those taken to protect property, or (3) those taken for food? If not, what is the total estimated kill of polar bear per year? Will oil company/ pipe line employees be given licenses and/or permits? Can hunters use airplanes at all and if so, for what purposes?

\section{Response:}

Extent of the waiver is 250 for all purposes. Polar bears may not be taken from airolanes, and airnlanes mav not he. used for transnnrtatinn to and frnm the hunting site. 
P. O. Box 3719

Georgetown Station

Washington, D. C. 20007

April 16, 1976

Ir. Sidney R. Galler

Jeputy Assistant Secretary

for Environmental Affairs

J.S. Department of Commerce

Washington, D.C. 20230

Dear Mr. Galler,

Thank you for sending the draft environmental impact statement "Consideration of a Waiver of the Moratorium and Return of Management of Certain Marine Mammals to the State of Alaska."

In response to your request for comments, the Society for Animal Protective Legislation considers totally inadequate the information given in what appears to be a decidedly offhand manner concerning humaneness or lack thereof in the taking of the enormously increased numbers of animals that may be killed under the Alaskan proposal.

A brief parenthetical note dropped into the revised regulations [5AAC 81.055 (14)] of the Alaska Department of Fish and Game is all the state seems to have been able to bring itself to do.

"(14) Permits issued under subsection (13) above shall specify the number of animals authorized to be taken, the location and manner (determined by the Commissioner to be humane) in which they may be taken, the period during which the permit is valid and any other conditions deemed appropriate."

No criteria of any sort are given. It appears to be business as usual for the commercial exploiters of marine mammals who have been unable to provide furs for the European market since enactment of the Marine Mammal Protection Act.

These non-native killers of infant seals and sea lions kept a very low profile during the lengthy Congressional hearings and debate on the Act. Indeed, they were totally invisible. Although the slaughter of baby seals in Canada was a major public issue, probably the one most responsible for focussing the massive public attention which led to passage of the Act, no official or individual from Alaska even let the Congress know that tens of thousands of baby seals were slaughtered each 
year in Alaska, too! Not until the law was in effect did these commercial interests come forward. They did so to ask for an economic hardship permit.

It was then, for the first time, that conservation and humane groups learned about the Alaskan seal and sea lion pup killings conducted for purely commercial purposes by non-natives. The requests for economic hardship permits were denied. Now, however, the commercial demand is reinstated in a full-blown proposal by the State of Alaska itself, and the federal government is proposing to accede to it.

There is far more suffering involved in shooting animals from a boat than in clubbing them on land (as is done in the Canadian baby seal kill) for the chances of wounding without killing are vastly increased. This fact has long been recognized by the United States which is a leader in preventing a return to pelagic sealing for the fur seals on the Pribilof Islands. However, the regulations submitted by the Alaska Department of Fish and Game include the following 5AAC 81.120(4): "... a motor driven boat underway may be used in taking marine mamnals, sea otter, wolves and coyotes..."

Pages 127 and 128 of the DEIS attempt to cover the matter of humane taking as required by the Act, but it is stated: "Marine mammals could be taken by any methods and means not prohibited." (Emphasis supplied.) Prohibited methods are Iisted. A contradictory sentence then states, "Marine mamals may be legally taken only: (1) with a hand-held rifle using a centerfire cartridge, except rifles capable of fully automatic fire; (2) with the aid of spears and harpoons that are hand held or thrown; (3) with the aid or use of surface transpor-. tation only; (4) with the aid of unleashed or unharnessed dogs, for polar bear only; and (5) with nets, shotguns, weapons using rim fire cartridges, or clubs, only as specifically authorized by permit." "The contradiction should obviously be cleared up. However, that is only a very small part of the problem.

Here are just a few of the questions which need to be answered: How can shooting at animals from a boat be an accurate means of producing instant death? What is humane about harpoons and spears thrown by hand? What would permit requirements by for using nets and the other listed methods? What does Alaska propose to do to prevent inhumane taking? What procedures will it follow to prevent violations if a waiver of the moratorium is granted? 
The fact that a greatly increased number of marine mammals will be killed if the proposal is granted makes the question of humane taking correspondingly greater. According to Table 4, page 99, DEIS, 12,892 additional animals would be taken under the proposed action, but it could be much higher. For example, sea lions in this chart are listed at 5,940, but on page 113 " we find "the limit imposed by the extent of the waiver will not exceed 15,000."

As for Largha seals (page 115) "The take under the proposed waiver would be limited to 20,000 animals."

It is not necessary to go through all the figures to demonstrate the potential for enormously increased taking under the proposal, and the correspondingly increased potential for inhumane taking under the vague terms of the regulations and the DEIS.

The DEIS (p. 121) states "The 1973 harvest of ice-breeding seals is 62 percent below the 1968-72 annual average..." Page 122 of the Appendix indicates that largha seals (ice-breeding spotted seal) are monogamous, live to at least the age of 35 , and "will leave a hauling area after only minor harassment." The likelihood of harm to these seals from pollution is noted. To subject them to heavy commercial killing would be backward step, contrary to the spirit of the Marine Mammal Protection Act.

Repeated emphasis on economic gains to "guides, processors and retailers of marketable products in the DEIS make plain that commercial interests are seeking to reverse the trend toward reduced taking of marine mammals in Alaska which very properly followed the first three years under the Marine Mamal Protection Act. A total of 71,360 animals could be taken under the proposed ceiling. In one year prior to the Act, over 50,000 harbor seals alone were killed to sell the skins (DEIS, p.99) so there is no question but that the ceilings may be reached.

It is interesting to note (DEIS, pp.29-30) that "More polar bears are now being observed in areas near the coast, and a significant number of maternity dens are again being found on mainland Alaska. It is not certain that this wholly represents an increase in the number of bears in the populations. The lack of disturbance by low flying small aircraft since the ban on use of aircraft for hunting and since cessation of sport hunting by the Act, might also be a factor in this distribution pattern." Here is a good environmental impact which the first 
three years of the Marine Mammal Protection Act has had. Given a chance, animals can return to their natural range when harassment is reduced. This beneficial trend should be continued. The American public wants it to be continued.

The Alaska Department of Fish and Game has much narrower interests, and it has shown itself to be both secretive and aggressive in protecting them. I have mentioned the fact that it never alluded to the massive kills of seal and sea lion pups during the series of hearings on the Marine Mammal Protection Act. Its stand on wolf extermination exemplifies the way in which it uses its powers. Radio tagging of wolves seemed to be intended for collection of scientific data, but it was turned into a means to track down and destroy the tagged animals and all their fellow members of the pack.

It is impossible to have confidence in an agency such as this where administration of the Marine Mammal Protection Act is concerned. The attached copy of a letter to Mr. Schoning, May 14, 1973, on the subject of the economic hardship requests gives additional documentation on the attitudes towards animals of Departmental spokesmen (for example, Mr. Vania's remark "Otherwise we'd be overrun with killer whales or mice or what have you."). Nothing has changed so far as can be ascertained from the DEIS. Unless there is a substantial change in regulations and directives, the State of Alaska should not be given control over the nation's magnificent populations of sea mammals.

The joint Monitor groups/Environmental Defense Fund letter dated April 19th examines a number of inadequacies in the DEIS with which the Society for Animal Protective Legislation also associates itself.

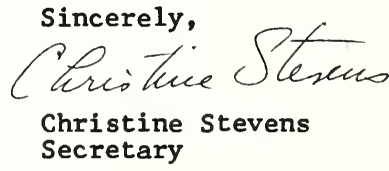

Enclosure 
May 14. 1973

Mr. Robert W. Schoning, Acting Director

National Marine Fisheries Sorvice

3300 Whit tehaven

Washlington, D.C. 20235

Dear Mr. Schoning,

The Soclety for Animal Protective Leglslation is opposed to the granting of economic hardship exemptions from the Marine Mammal Protection Act to the persons who testifled at Kodlak on Apr1I 11th. Our opposition $1 \mathrm{~s}$ basod on several different points 8

1) The hearlings are far from belng conclusive with regard to the accuracy or completeness of disclosures made by those asking to lelll the animals. For example, comments and questions, page 50 and onwards, with respect to $\mathbf{M}$. Randali's statement that bis sole means of 11ve11hood for the past ton jears has been sale of marine manmals ralses more questions than thoy answer. If bls statement 18 untrue and an economic hardship exption is given him the Marine Mammal Protection Act w111 be undermined in 1 ts very flrst year of operation. Full and complote disclosure $1 \mathrm{~s}$ eseential before his request could be given even prelimsnary consideration. The simple word of any person testifying to oconomlc hardship is unacceptable. At the very least, the person wapuld supply his Income tax statements to the National Marlne Fishorles Sor$\nabla 10 e$.

2) Severe oconoulc hardshlp as we belleve 1t was onv1saged by Congress in approving this provision of the Act is not present in the cases presented. For example. Mr. ilngs states that he $1 \mathrm{~s}$ gainfuliy omployed by the. Internal iovenue service and takes leave without pay to make money from sea mamals. He himself agress that his is not a case of real bardship.

3) It 18 clear from the testimony that the economic gain to be had by lefling any of the animals is pitiruliy small. For example, Mr. Woelkers testlrled. "I have taken sea lion for the - mostly for the shrimp boat Industry, and the hides were salvaged and used.... The pups are so small and thore 13 no real market value for pups as far as meat goes. There is no fat on them to speak of....

"The number of seals I've taken 18 approximatel - that's a hand question - this year about 200, a little over 200. Soa lion run about .25 or $30 \ldots$ The wlnter berore 1 t was a smaller number about 2 or 3 hundred seal and 25 or 30 sea l1on. There never was much of a blgh market for sea lions excopt for that I could personally use.... The winter before I actually had to work at odd jobs and thls and that to get the equipment to bulid up the business more or less." 
4) The persons teatifying state they plan to shoot many of the apinals in the water. Such a practioe moans that some animals will bo wounded and die a painful lingoring death. Mr. Woelkers' claim that his recovery rate $1897-98 \%$ sounds great is exagserated. If he 18 that good a shot, sitting in a rocking boat, alming at a swiming $80 a l$ which. according to hias, must bo shot in such a way that $1 t$ will roat, bo bas talents unheard of among other seal huntere. However, we have only ha ow word for his fabulous expertise as a sharpshooter. The others who testifled were Allent on their percentage of instant lilis.

Shooting at adult seals hiverways been the most cruel sealing method. Dr. Harry IIIlle writing of the Canadian seal hunt in 1964 sald "Later in the season when the bables bave taken to the water at three weeks to a month, the adult seals gather on the 1ce to moult. Thej are then shot from a distance with rifies, involving great cruelty and wasto. many escapling badiy wounded to die under the 1ce. Losses have been as high as two lost for every one secured and I have seen as many as fire blood tralls leading off one single lce floe with not one seal recovered." (The complete articlo 18 attached, and 1t 18 worth noting that the date of the lnternational protests described colncides with the beglnning of similar activitios in Alaska which bave, so Sar. been able to staj out of the internatlonal apotilght.

There is a strong Implication in Mr. Vania's use of the phrase "roo trleved harvest that many of the seals swim away wounded. Mr. Valla sald the 1965 "retrieved harvest exceeded 50,000 animals." In the courer: of hls leagthy testimony. Mr. Vania indicated no interest whateoover in bumano taklng mothods. Hs casual approach 18 exemplified in the tatement. "You don't have to monitor anj rookery that he maj take these animals from because that harvest is 80 Insigniflcant to the sea lion population as a whole that I wouldn't worry about it at all." Iater. apeaking of the thousinds of animals Woelkers and randall propose to kill he added, "It'B just nothing. - It's drop in the bucket."

If no manttoring is to be done, how can there be any assurance that the killing of the anlmals be done humenely as roquired under tho terms of the Act?

5) Mr. Vania's disrospectrul approach to animals suggests that bo is very poorly qualified to act as an officlal ontrusted with any part of the administration of the Marine Marmal Protection Act. Spearlng of population control be says."... otherwise we'd be overrun with kdller whales or mice or what have jou." The Alaska Department of Flsh and Game opposed the Act in hearings before 1 t was passed. Mr. Vania's viows remain unchanged. "It's really a shame the law has denled those peoplo this right." to k1ll thousands of baby seals and sea lions for tho buropean market. Enforcement of the requirements of the Act should the economic hardshlp exemptions be allowed should be carried out by federal government personnel only.

6) The bat seal was the symbol of public protest whlch brought about enactment of tho Marine Mammil Protection ict. It would be a bold 
and outragoous reversal of the w11l of Congress if. in the flrst fow months of 1ts exlstence the Act should be, as it were, reperled through a back-door maneuver such as this. If the exemptions to Woolkers, Randall and others in a similar business are granted, the cloar intent of the Act to 1) stop the klll1ng of baby seals and othor sor mamal. 2) require humane methods of taking of any animals, 3) require thorough study of effects on specles populatlons and ocean ecosystems of ang takeng before it 18 allowed, will all be grosidy violated.

The ruture of the Marine Mamnal Comnission w11l be undermined if these exemptions are allowed by the Natlonal Marlne Flsherles Sertico. Confidenee in the MMF 1 self which, at the present time, is bullding up as the rosult of the scruting which has boen given to othor requesta for exemptions, would be destroyed at one blow. We strongly urge that this commerclal lliling by white hunters which was never made an 1 ssue in the lengthy hearings on the leglslation and which only now emerges in an effort to undercut the Intent of Congress, be disapproved and that the proposed contract with the State of Alaska to onsorce the Marino Mammal Protection hct there be rejected.

An amendment to exempt the State of Alaska fram the provisions of the Act was dereated on the floor of the sengte. It should not be allowed to ro-onter adinlatrativelJ.

incerely.

Christine itevens

Socretary

Enclosures

CS/me 


\section{Comment:}

Pages 127 and 128 of the DEIS attempt to cover the matter of humane taking as required by the Act, but it is stated: "Marine mammals could be taken by any methods and means not prohibited." (Emphasis supplied.) Prohibited methods are listed. A contradictory sentence then states, "Marine mammals may be legally taken only: (1) with a hand-held rifle using a centerfire cartridge, except rifles capable of fully automatic fire; (2) with the aid of spears and harpoons that are hand held or thrown; (3) with the aid or use of surface transportation only; (4) with the aid of unleashed or unharnessed dogs, for polar bear only; and (5) with nets, shotguns, weapons using rim fire cartridges, or clubs, only as specifically authorized by permit." The contradiction should obviously be cleared up.

\section{Response:}

The FEIS has been modified to reflect the comment. Bee page 127 of the FEIS.

Comment:

How can shooting at animals from a boat be an accurate means of producing instant death? What is humane about harpoons and spears thrown by hand? What would permit requirements be for using nets and the other listed methods? What does Alaska propose to do to prevent inhumane taking? What procedures will it follow to prevent violations if a waiver of the moratorium is granted?

\section{Response:}

1) Seals which are normally shot in the water, swim with only their heads visible above the water. This means that the shot would either miss its mark or would hit the head. A high-velocity bullet striking a seal's head will invariably produce instantaneous death, without pain or suffering.

2) While harpoons are permitted to be used under the regulations, as a practical matter they are no longer used either for taking seals or beluga whales. Generally they are used by native hunters to recover animals that have already been killed with a rifle.

3) The State indicates that permission to use nets, shotguns, rimfire weapons, or clubs would be granted only under special circumstances. For example, nets would never be used for taking harbor seals but might be permitted for beluga in those few instances where a permit applicant has proven to be skillful at using a net in an efficient and humane way. Since al1 permitted methods of take are considered humane, all inhumane take must be considered as a violation of State law and regulations. If management were returned, the State has 82 commissioned officers in the Division of Fish and Game who would enforce the State's fish and game laws. The State's ability to carry out its law enforcement program is aided by the presence of other organizations with law enforcement powers. A violation of any State or Federal statute concerning marine mammals would be prosecuted through due process of the law similar to any other fish and game violation. 
Comment:

The fact that a greatly increased number of marine mammals will be killed if the proposal is granted makes the question of humane taking correspondingly greater. According to Table 4, page 99, DEIS, 12,892 additional animals would be taken under the proposed action, but it could be much higher. For example, sea lions in this chart are listed at 5,940, but on page 113 we find "the limit imposed by the extent of the waiver will not exceed 15,000."

\section{Response:}

The extent of the waiver was based upon a determination of the optimum sustainable population, not upon the present day needs of the State. Therefore, the table on page 99, vol. I, DEIS summarizes the anticipated near-term needs of the State and would not coincide with the proposed action as summarized on page 8 of the DEIS, vol.I.

\section{Comment:}

The DEIS (p. 121) states "The 1973 harvest of ice-breeding seals is 62 percent below the 1968-72 annual average..." Page 122 of the Appendix indicates that largha seals (ice-breeding spotted seal) are monogamous, live to at least age 35, and "will leave a hauling area after only minor harassment." The likelihood of harm to these seals from pollution is noted. To subject them to heavy commercial killing would be backward step, contrary to the spirit of the Marine Mamma 1 Protection Act.

\section{Response:}

A careful reading of the DEIS will show that the proposed action does not include a commercial harvest of largha seals. It is anticipated that a take of 2,750 seals for subsistence purposes and 30 animals for scientific research will be the extent of the State's needs.

\section{Comment:}

Repeated emphasis on economic gains to "guides, processors and retailers of marketable products" in the DEIS make plain that commercial interests are seeking to reverse the trend toward reduced taking of marine mammals in Alaska which very properly followed the first three years under the Marine Mammal Protection Act. A total of 71,360 animals could be taken under the proposed ceiling. In one year prior to the Act, over 50,000 harbor seals alone were killed to sell the skins (DEIS, p.99) so there is no question but that the ceilings may be reached.

\section{Response:}

Prior to passage of the MMPA, the take of harbor seals averaged 8,000 to 12,000 animals with a single year high (1965) of 50,000. Under the proposed action, 14,000 harbor seals would be permitted to be taken for all purposes. Based on the hearing record and the ALJ decision, a take of this Tevel (i.e. a take of 14,000 with $25 \%$ pups would equate to the ALJ recommendation of 8,461$)$. would allow the stock to remain within OSP. (See also page 115 of the FEIS). 
• 

